UNIVERSIDADE DE SÃO PAULO

FACULDADE DE FILOSOFIA, LETRAS E CIÊNCIAS HUMANAS

DEPARTAMENTO DE ANTROPOLGIA

PROGRAMA DE PÓS-GRADUAÇÃO EM ANTROPOLOGIA SOCIAL

BRUNA SOARES

ANGOTTI BATISTA DE ANDRADE

\title{
ENTRE AS LEIS DA \\ CIÊNCIA, DO ESTADO E DE DEUS \\ O surgimento dos presídios \\ femininos no Brasil
}

SÃO PAULO 


\author{
UNIVERSIDADE DE SÃO PAULO \\ FACULDADE DE FILOSOFIA, LETRAS E CIÊNCIAS HUMANAS \\ DEPARTAMENTO DE ANTROPOLGIA \\ PROGRAMA DE PÓS-GRADUAÇÃO EM ANTROPOLOGIA SOCIAL
}

\title{
ENTRE AS LEIS DA \\ CIÊNCIA, DO ESTADO E DE DEUS \\ O surgimento dos presídios femininos no Brasil
}

Bruna Soares Angotti Batista de Andrade

Dissertação apresentada ao Programa de Pós-Graduação em Antropologia Social do Departamento de Antropologia da Faculdade de Filosofia, Letras e Ciências Humanas da Universidade de São Paulo, para obtenção do título de Mestre em Antropologia Social.

Orientadora:

Profa. Dra. Ana Lúcia Pastore Schritzmeyer

SÃO PAULO

2011 


\section{Bruna Soares Angotti Batista de Andrade}

\section{ENTRE AS LEIS DA CIÊNCIA, DO ESTADO E DE DEUS. \\ O surgimento dos presídios femininos no Brasil}

Dissertação apresentada ao Programa de Pós-Graduação em Antropologia Social do Departamento de Antropologia da Faculdade de Filosofia, Letras e Ciências Humanas da Universidade de São Paulo, para obtenção do título de Mestre em Antropologia Social.

Orientadora:

Profa. Dra. Ana Lúcia Pastore Schritzmeyer

Aprovado em:

\section{Banca examinadora}

Prof. Dr.

Instituição: Assinatura:

Profa. Dra

Instituição: Assinatura:

Prof. Dr.

Instituição: Assinatura: 
Este trabalho teve como objetivo principal compreender quais elementos pautaram os projetos e as práticas das prisões femininas brasileiras, no final da década de $30 \mathrm{e}$ início dos anos 40. Buscou-se verificar em que medida prescrições de pensamentos criminológicos em voga, como o Direito Penal Clássico - que indicava a pena para expiação da culpa e via o crime como uma escolha do indivíduo - e da Antropologia Criminal - para quem o homem nascia delinquente e a pena deveria ser medida médica para curar criminosos - estiveram presentes na caracterização da delinqüência feminina e no cotidiano dessas instituições. Foi por meio da leitura de documentos da época, entre eles periódicos como A Estrela e os Arquivos Penitenciários do Brasil, que foi possível recompor os argumentos e as metas que justificaram a criação dos estabelecimentos prisionais femininos no país, bem como identificar a quem eles estavam voltados. Conclui-se, ao final, que o sistema penitenciário feminino foi edificado de maneira bastante peculiar, mesclando preceitos das duas referidas escolas criminológicas e elementos morais religiosos, com o objetivo de devolver à sociedade boas mães e esposas, ou seja, mulheres livres dos vícios e das mazelas que as desviavam do caminho esperado. Neste sentido entendia-se que a criminalidade feminina, vista como um desvio do papel social que a mulher deveria cumprir, precisava ser contida e corrigida. Daí porque o formato escolhido para as primeiras prisões de mulheres no Brasil privilegiou o resgate de elementos valorados como sendo próprios do feminino e confiou a uma Congregação religiosa a missão de executá-lo.

Palavras-chave: Crime, mulheres presas, delinquencia feminina, instituições prisionais, religião, Brasil (1930-1950) 


\begin{abstract}
This dissertation had as its main objective to understand which elements guided projects and practices of women's prisons in Brazil in the late 30's and early 40's. It sought to verify the extent to which criminological prescriptions, as the ones from Classical Criminal Law - that said that penalties served to purge guilt and that crime was an individual's choice - and from Criminal Anthropology - for whom the Man was born as a delinquent and penalty should be a medical measure to cure law offenders - were present in the understanding of female crime and the daily life of these institutions. By reading documents from that period, among them journals such as $A$ Estrela and Arquivos Penitenciários do Brasil, it was possible to rebuild arguments and goals that were used to justify the foundation of women's prisons in the country, as well as identify for whom they were built for. It concludes that women's prison system were built in a very peculiar way, mixing components from the two above-mentioned criminological schools with religious and morals elements, aiming to give back to society good mothers and wives, that is, women free from the vices and illness that moved them away from their expected paths. In that sense, female criminality, seen as a deviation from the social role that women were supposed to perform, should be contained and corrected. That explains why a religious Congregation was responsible for running the first women's prisons in Brazil, which privileged the recovery of elements valued as attached to the feminine.
\end{abstract}

Key words: crime, women prisoners, female deliquency, prisional institutions, religion, Brazil (1930-1950) 
Ao Paulo

por me ensinar, todos os dias, os sentidos da palaura companbeiro 


\section{AGRADECIMENTOS}

Sempre adorei ler agradecimentos de livros e trabalhos acadêmicos em geral. Dos mais diretos aos mais poéticos, eles expressam muito do momento vivido por seu autor, da confecção do texto, de seus prazeres e dificuldades. Os pedidos de desculpas pelas ausências, que aparecem em muitos trabalhos, sempre me intrigaram - seria mesmo a produção acadêmica capaz de gerar tantas ausências a ponto do autor publicizá-las? Ao longo da escrita desta dissertação, descobri que sim, pois, muitas vezes o "não" se sobrepôs ao "sim" e, a cada dia, as expressões "não vou", "não posso", "não dá" se tornaram mais frequentes no meu vocabulário. Assim, coletivamente agradeço, com imenso carinho, a paciência de todas e todos que ouviram os meus "nãos" positivamente, como promessas de presenças futuras. Mas, mais importante que as ausências, os agradecimentos tratam das presenças e são delas que passarei a falar agora.

Agradeço à minha mãe, Hélia, pelo amor, estímulo, apoio, amizade, exemplo e carinho de todas as horas. É com o "tamanho gigante" do seu coração que me mostra todo dia que "viver" é infinitamente maior que simplesmente "existir".

Ao Paulo, por todo o amor, bom humor, paciência (e muita), ajudas acadêmicas, companheirismo, carinho e força, bem como por me fazer tão feliz e tornar a nossa casa o melhor lugar do mundo;

À querida Professora Ana Lúcia Pastore Schritzmeyer, minha orientadora no mestrado, pelo apoio, incentivo, confiança, carinho, sabedoria compartilhada, dicas, leitura, dedicação e conversas, tão importantes para o desenvolvimento deste trabalho;

Ao Professor Fernando Salla, pelas dicas de leitura, sugestôes de pesquisa, generosidade e pelas valorosas contribuições feitas na banca de qualificação; e à professora Lilia Schwarcz, pela cuidadosa leitura do relatório de qualificação, que rendeu sugestões fundamentais para a continuidade do trabalho, bem como pela ajuda com as imagens; aos dois por prontamente aceitarem participar da banca de defesa 
da presente dissertação;

À minha amada irmã, Nana, pelo carinho, dedicação, leitura, perfeccionismo, paciência e companheirismo, por sempre acreditar e por sermos a dupla que somos; e ao Demian, cunhado querido, pelo cuidadoso e carinhoso trabalho de diagramação, pelo convívio e amizade;

À querida tia Heliana, pela dedicação e auxílio com este trabalho, materializada na leitura cuidadosa e na preciosa ajuda com o manuseio e análise das imagens, linguagem até então desconhecida para mim. Ao tio Zé pelo carinho;

Aos queridos tios Leon e Elisa pela presença constante, afeto, exemplo acadêmico, apoio e conversas, bem como por serem também minha Casa por aqui;

Aos professores e professoras do PPGAS em especial Heloisa Buarque de Almeida, Laura Moutinho, José Guilherme Magnani e Julio Simões, pelos ensinamentos e apoio;

Aos professores e professoras que muito me ensinaram e dos quais tenho sempre as melhores lembranças: Rogério Arantes, Cláudio Couto, Carla Garcia, Edson Passetti, Janaína Paschoal, Mariza Werneck, Vera Malaguti Batista e Monica Carvalho;

Aos queridos companheiros e companheiras do Nadir - Núcleo de Antropologia do Direito - pelos excelentes debates, leituras, compartilhamentos e risadas, que tornam o Direito "divertido" e a Antropologia uma boa aventura. Em especial às amigas e amigos da velha guarda Ana Gabriela, Tati, Maíra, Erika, Adalton e Pauléo. À Ana Letícia pela força e doçura e ao Igor, pela dedicação e bom humor;

À amada vovó Naná, minha raiz, pelos afagos, mimos e amor;

Ao meu pai, Nivinho, hoje tão presente, por esse reencontro que tantas alegrias têm trazido;

Ao querido Avilinha pela alegria e diversão constantes;

À dona Cida, seu Gênesis e Luisão - minha segunda família - pelo carinho e colo que significam casa; À dona Cida, especialmente, pela cuidadosa leitura e revisão do texto, bem como pelo constante estímulo; e ao Luisão, pela ajuda com a bibliografia. 
À querida Fezinha, a quem tanto admiro, pela amizade-irmandade, pelos papos sérios e pelos nada sérios, pelos cuidados, diversões, presença e carinho fundamentais;

À Loló, "amiga astral", que tanto me ensina, pelos ideais compartilhados, pela super ajuda com o trabalho e pelas ótimas risadas, com direito à melhor gargalhada do mundo;

Às minhas "irmãs" Aninha, minha "eterna" leitora, por extrair o que há de melhor e mais engraçado em mim; Camilinha, pelo companheirismo e irmandade que floresceu como o nosso jasmim manga; Mel e Gica amigas de sempre; Caroca, que mesmo do outro lado do mar está sempre perto; Liloca, por trocarmos "letters from the princess"; e Mazinha, vizinha-irmã querida;

Às minhas “mães" Tatá, tia Maria Alice, tia Ré (e Marcondão), tia Irene, Tida, pelos colos e cuidados de toda a vida;

Aos companheiros do PPGAS, em especial Samantha Gaspar, Stefanie Franco, Giancarlo Machado (e Naná) e Edu Dimitrov pelas ótimas conversas e compartilhamentos;

Aos amigos da vida toda Vi Kanashiro, Mari Mota, Ari, Sil, Alê Octaviani, Ramyres, Carol Freitas ("super” antropóloga), Fred Horta, Dani Daia, Má Varconte, Iolanda, Guilhas, Laura, Melissa, Marquinhos, Fernanda Lorca, Ana Flávia, Lincoln, Vi Calderoni, Vandoca, turminha da GO, Zé do Pijama, Kiko (e Má) e Jujú por estarem sempre perto;

À turminha da Conectas Direitos Humanos, em especial, Elô, pela amizade companheirismo e exemplo; Muriel, pela lente linda com a qual vê o mundo; Milô, parceirinha de ótimas conversas; Vivi, pelas alegrias garantidas; Marcelinha (e Serginho), pelo exemplo de militância e amizade; Samuca, por ser o meu rabugento favorito; Júlia, pela doçura e apoio; Nathalie, pelo divertido trabalho em conjunto; Gi, por toda a coragem e Fabi, pelas ótimas risadas;

À Maíra Zapater pelo "disk penal", pela Beth e por tudo que ainda faremos juntas, com a graça de São Jorge;

Ao Vitão, por todo o $A x e ́$; 
À Susan, por toda a previsão;

Aos amigos Reginaldo, Cidinha e Marina, pelo caloroso acolhimento de sempre, que apesar de ser "Igarapava" lembra "Uberaba";

À América, por cuidar da gente com tanto carinho;

À Ofélia, companheirinha constante, literalmente;

Às companheiras da especialização em Criminologia, em especial, Érica, Ilana, Maria Rosa, Martina, e Nara, pela amizade que "saiu do Centro".

Aos amigos da San Fran, em especial ao Fred Diehl pelas ótimas conversas e também pelas portas abertas;

Ao Clerinho, "que da janela ficou feliz", pela força em terras cariocas com os microfilmes;

Aos queridos e queridas de Uberaba, representados, aqui, pela Joaninha, que tanto amo;

À equipe do Museu Penitenciário Paulista, em especial Sidney Oliveira, João Carlos Silva, Aline e Rogério e aos funcionários do Centro de Estudos e Pesquisas da Escola de Gestão Penitenciária do Estado do Rio de Janeiro, pelo acolhimento, apoio e material compartilhado;

Às funcionárias da Secretaria de Segurança Pública do Estado do Rio Grande do Sul, especialmente Raquel Arruda Gomes, chefe de Gabinete do Secretário de Segurança Pública, por ter sido tão atenciosa e gentil no compartilhamento do material;

Aos funcionários da seção de periódicos da Biblioteca Nacional e da Biblioteca Central da Faculdade de Direito da USP, pela colaboração;

Aos funcionários do Departamento de Antropologia e PPGAS Rose, Soraya, Celso, Edinaldo e Ivanete, pela ajuda sempre necessária;

Ao Centro de Documentação e Informação Científica - Cedic - da PUC-SP, pelo empréstimo da leitora de microfilme;

À Paula Morgado Dias Lopes por, generosamente, ter ajudado com o olhar sobre as fotografias;

À Amelinha Teles, pelo exemplo sem igual; 
À Fernanda Emy, pela dica das estatísticas e conversas;

À Angela Artur, pelas trocas sobre as nossas pesquisas;

À querida Lúcia, por juntas termos conseguido tantos progressos;

À professora Colette Parent, pela leitura do projeto e sugestões;

À Irmã Zulma pela entrevista, livros e recepção; e Maria da Penha Risola Dias, pela entrevista e material compartilhado;

À Capes pela bolsa de mestrado que me possibilitou desenvolver esta pesquisa. 


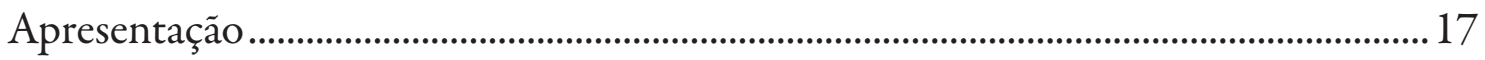

Considerações iniciais...................................................................................................... 28

\section{Capitulo Um}

Breve histórico dos debates prisionais e da legislação penal no Brasil .52

Legislação penal .....................................................................................................52

Cenários legislativo e punitivo nas décadas de 1930 e 1940 ..........................61

Penitenciaristas...........................................................................................................67

Práticas punitivas......................................................................................................

\section{Capitulo Dois}

"Dever ser" e "não ser" femininos ....................................................................................90

O "dever ser" ........................................................................................................90

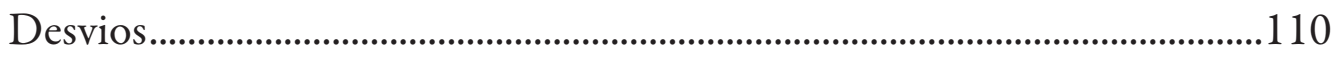

Agentes do desvio e o Sistema de Justiça Criminal .......................................120

Registros e tipologias.......................................................................................... 141

Capitulo Três

Classificando a "mulher delinquente".........................................................................151

Diálogo com a Antropologia Criminal..........................................................155

Estereótipos - traçando a "mulher delinquente".............................................160

Mais ou menos criminosa? ...................................................................................175

Capitulo 2uatro

Projetos e práticas dos cárceres femininos..................................................................187

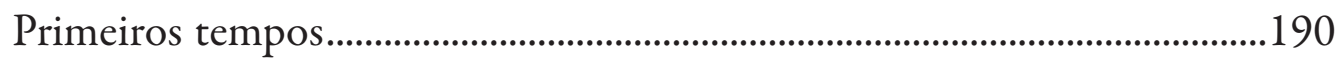

A Congregação de Nossa Senhora da Caridade do

Bom Pastor d' Angers...........................................................................................196 
A presença das Irmãs do Bom Pastor d' Angers nos cárceres femininos

Desígnio e cotidiano - elementos do aprisionamento feminino nos primeiros tempos

Considerações finais .272

Epílogo. .292

Bibliografia .307 
TABELA 1. Detenções policiais e correcionais no Estado de São Paulo (1943)....... 123

TABELA 2. Distribuição de mulheres detidas na capital e no interior segundo nacionalidade (1943) ..........................................................................................

TABELA 3. Motivos da detenção de mulheres por profissão na capital e no interior (1943)

TABELA 4. Crimes ocorridos na capital segundo sexo (1943)

TABELA 5. Distribuição de mulheres acusadas e/ou condenadas por crimes na capital segundo nacionalidade (1943)

TABELA 6. Discriminações dos tipos de prisões entre mulheres (1943) .134

TABELA 7. Distribuição de homens e mulheres recolhidos em asilos e manicômios (1938-1943) .136 


\section{GRÁFICOS}

GRÁFICO 1. Distribuição de mulheres detidas na capital e no interior segundo

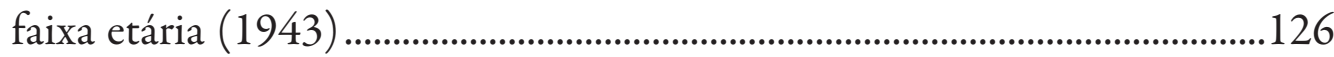

GRÁFICO 2. Distribuição de mulheres detidas na capital e no interior segundo

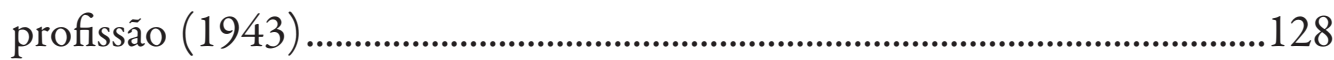

GRÁFICO 3. Distribuição de mulheres detidas na capital e no interior segundo

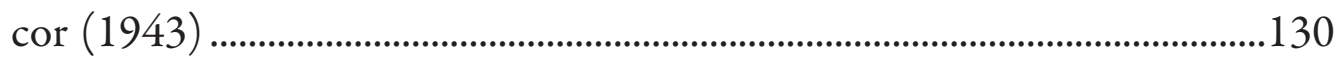

GRÁFICO 4. Distribuição de mulheres acusadas e/ou condenadas por crimes na capital segundo profissão (1943).

GRÁFICO 5. Distribuição de mulheres acusadas e/ou condenadas por crimes na capital segundo cor (1943) 
APB - Arquivos Penitenciários do Brasil

AE - A Estrela

CP - Código Penal

CPP - Código de Processo Penal

EPCSP - A Estatística Policial-Criminal do Estado de São Paulo 
Não posso dizer pai nosso se não vejo em todos os homens irmãs meus... Não posso dizer que estais no céu se o que mais me preocupa são os bens da terra...

Não posso dizer santificado seja o vosso nome se a minha vida cristã é falsa e me preocupo com a minha própria santificação...

Não posso dizer venha a nós o vosso reino se não permito que Deus cresça em mim e reine em minhas atitudes e sentimentos...

Não posso dizer seja feita a vossa vontade se o que me importa é sempre o que EU quero...

Não posso dizer assim na terra como no céu se sempre tento impor a Deus a minha vontade e sempre busco as ilusóes terrenas...

Não posso dizer o pão nosso de cada dia nos dai hoje se não sou capaz de dividir o meu pão com os necessitados...

Não posso dizer perdoai as nossas dividas e ofensas, assim como nós perdoamos nossos ofensores se nunca perdôo ninguém e minha vida é uma permanente ofensa à justiça e à caridade quando julgo meus irmãos...

Não posso dizer não nos deixei cair em tentação se vivo em busca de prazeres tentadores e fujo à participação na construção de um mundo novo...

Não posso dizer mas livrai-me do mal se a minha própria vida é um tributo a tudo que é mal...

Não posso dizer amém se minto em dizer que aceito tudo isso em minha vida...

(Cartaz escrito à mão em cartolina decorada em verde e amarelo, colada no corredor das salas de aula da Penitenciária Feminina de Sant'anna, copiado em visita feita em 24/02/2011) 


\section{APRESENTAÇÃO}

Desde o período colonial, no Brasil, as mulheres foram encarceradas em estabelecimentos onde prevaleciam prisioneiros do sexo masculino, sendo a elas raramente destinados espaços reservados. Prostitutas e escravas, em sua maioria, as mulheres eram confinadas junto aos homens, frequentemente dividindo a mesma cela. Narrativas de abandono, abusos sexuais, problemas com a guarda - na maioria das vezes masculina -, doenças, promiscuidade e outros, envolvendo as mulheres encarceradas, estavam sempre presentes nos trabalhos de penitenciaristas ${ }^{1}$ do século XX. A partir de meados do século XIX, quando a precariedade da situação prisional brasileira começou a ser explicitada e diferentes profissionais passaram a se dedicar a buscar soluções para resolvê-la, o tema das mulheres presas entrou em pauta. Relatos esparsos e alguns relatórios de diferentes períodos mostram a situação das encarceradas nas prisões e casas de correção brasileiras. Em geral, ressaltam não apenas a precária condição em que se encontravam as mulheres presas, mas também o pe-

$1 \quad$ No primeiro capítulo há um tópico explicando quem eram os penitenciaristas e suas funções. 
queno número de condenadas e processadas detidas, o que, possivelmente, justificava o adiamento de soluções para tal questão.

Um relatório produzido em 1831 por comissão responsável pela verificação da situação dos prédios públicos destinados à caridade, dentre eles as cadeias, destacava que, em relação às mulheres retidas na Cadeia de São Paulo, era necessária a separação das condenadas das não condenadas, bem como a distribuição de alimentos e roupas, para que elas não precisassem se prostituir no recinto (SALLA, 1999, p. 51). De acordo com Salla, a Cadeia - um dos dois estabelecimentos prisionais que funcionavam na cidade no final do século XIX -, "misturava condenados e aqueles que aguardavam julgamento; condenados à pena de prisão simples permaneciam junto aos que cumpriam pena de prisão com trabalho; galés, dementes, homens, mulheres, crianças conviviam no mesmo espaço" (SALLA, 1997, p. 295).

Responsável por um relatório acerca da situação prisional brasileira - a ser entregue ao então ministro da Justiça -, o penitenciarista José Gabriel de Lemos Britto percorreu o Brasil, entre os anos de 1923 e 1924, analisando a situação carcerária nos principais estados. Tal relatório resultou em um livro denominado Os Systemas Penitenciarios do Brasil, publicado pela Imprensa Nacional em 1924, no qual o autor trata de temas nacionais como legislação e delinquência no país, bem como explicita a situação prisional em cada um dos estados visitados, registrando um vasto panorama do encarceramento no período².

As mulheres pouco aparecem em seu relato, pois a grande maioria dos encarcerados à época era do sexo masculino. Nas poucas informações sobre elas, Lemos Britto mostra que na cadeia de Fortaleza, no estado do Ceará, havia um total de 106 detentos, sendo 101 homens e cinco mulheres. Na Capital da Paraíba havia um total de 175 detentos, dentre os quais 173 eram homens. Na cadeia da capital do estado de Sergipe, que o autor classifica como hedionda, havia, à época, 74 ho-

2 Em geral as estatísticas reunidas em seu trabalho são das penitenciárias das capitais dos estados brasileiros, dada a dificuldade de percorrer todas as cidades com cadeias ou estabelecimentos prisionais de algum tipo. Mesmo quando o autor cita casas de detenção e cadeias em cidades interioranas, em geral não apresenta dados numéricos. 
mens e duas mulheres. Os encarcerados na Capital do Piauí eram 80 homens e uma mulher. Já em São Luís do Maranhão havia um total de três mulheres e 143 homens presos (LEMOS BRITTO, 1924). Especificamente sobre os estabelecimentos prisionais da cidade do Rio de Janeiro, então capital do país, Lemos Britto frisa que na Casa de Detenção havia uma ala separada para as mulheres e que essas "ocupam tres prisões do fundo, também isoladas, e a cargo de duas senhoras, mas essas prisões são de máu aspecto" (LEMOS BRITTO, 1925, p. 162).

Data de 1928 o relatório intitulado As Mulheres Criminosas no Centro mais Populoso do Brasil do então presidente do Conselho Penitenciário do Distrito Federal, Cândido Mendes de Almeida Filho, no qual o autor detalha dados de mulheres encarceradas entre julho de 1926 e outubro de 1927 nos Estados do Rio de Janeiro, São Paulo, Minas Gerais, Espírito Santo e no Distrito Federal. Publicado no Diário Oficial de 4 de Março de 1928, o relatório foi feito uma vez que a situação das mulheres condenadas e processadas muito preocupava o Conselho Penitenciário, dado o abandono em que se encontravam, o que denunciava a precariedade do sistema prisional nacional (ALMEIDA, 1928, p. 6293).

Segundo os dados publicados nesse relatório, no ano de 1926 havia oito mulheres presas no Distrito Federal, duas em Niterói, então capital do estado do Rio de Janeiro, 18 no Estado de São Paulo e 15 no Estado de Minas Gerais - a contagem reúne aquelas que ainda respondiam processo e as já condenadas. Em 1927 eram 16 as presas processadas no Espírito Santo e uma condenada. Naquele ano, somando todas as condenadas desses estados e do Distrito Federal, havia um total aproximado de 39 condenadas por crimes cumprindo pena em diferentes estabelecimentos. Dentre as razões para a condenação estavam as práticas de homicídio, infanticídio, ferimento, roubo e uso de tóxicos. Além destas condenadas, havia ainda aquelas mulheres consideradas contraventoras, que não se enquadravam legalmente como criminosas, mas eram recolhidas às casas de correção, em geral por "vadiagem". No Distrito Federal o autor mapeou, durante sua pesquisa, 16 contraventoras, porém não conseguiu reunir dados dos outros estados analisados (ALMEIDA, 1928, p. 6293). Uma pesquisa realizada pelo Conselho Penitenciário do Distrito Federal em 
1934 encontrou, no universo de todos os presos das capitais dos estados, 46 mulheres presas para 4633 sentenciados do sexo masculino, ou seja, 1\% da população carcerária das capitais era formada por mulheres ${ }^{3}$ (APB, 1942, ano II, p. 309).

Apesar do debate sobre os presídios femininos no país ser pauta da discussão carcerária desde as últimas décadas do século XIX, foi somente na década de 1940 que os estabelecimentos prisionais só para mulheres foram criados em alguns estados brasileiros. Tentativas anteriores de estabelecimento de presídios femininos no país foram feitas. Vale ressaltar, nesse sentido, a criação do Patronato das Presas, no ano de 1921, que tinha como objetivo principal conseguir "solução condigna" para o problema das criminosas, de preferência propiciar a instalação de uma prisão especializada para mulheres. Influenciadas pelas prisões femininas presentes em outros países latino-americanos - como Argentina e Uruguai - senhoras da sociedade carioca e Irmãs da Congregação de Nossa Senhora do Bom Pastor d 'Angers', presididas pela Condessa de Cândido Mendes, mulher do já mencionado presidente do Conselho Penitenciário do Distrito Federal, formavam o Patronato, cujo lema era "amparar, regenerando".

Ideias como centralizar em um único estabelecimento, de preferência agrícola, as mulheres condenadas dos estados de Minas Gerais, Rio de Janeiro e São Paulo, foram divulgadas pelo Patronato, com o apoio do Conselho Penitenciário do Distrito Federal'5 . De acordo com relatório do Patronato, escrito em 1927 e publicado no

3 A pesquisa "A prisão dentro da prisão: uma visão sobre o encarceramento feminino na 5. ${ }^{a}$ Região Penitenciária do Rio Grande do Sul”, coordenada pelo criminólogo Luiz Antônio Bogo Chies, de 2008, apresenta dados recentes do encarceramento feminino. Além de mostrar como as prisões mistas ainda são uma realidade no Rio Grande do Sul, o que denota o descaso governamental em relação às mulheres presas, aponta que, apesar do aumento do índice de mulheres encarceradas, estas ainda são minoria no sistema. Dados de 2011 do International Centre for Prison Studies, da University of London, destacam percentagens de aprisionamento feminino em 206 países e territórios. Destes, as Maldivas apresentam o maior percentual de mulheres presas (21,6\% do total da população carcerária) e as Ilhas Salomão, o mais baixo $(0,4 \%)$. O Brasil está na $43^{a}$ posição com um total de $7 \%$ de mulheres compondo o universo carcerário do país, o que representa, em números reais, aproximadamente 34.750 mulheres. Na maioria dos 206 países e territórios que compõem a tabela, a população carcerária feminina está na faixa de $4 \%$ a $8 \%$ do total de presos. http://www.prisonstudies.org/info/worldbrief/wpb stats. php?area $=$ all\&category $=w b \_$female, acesso em 29/10/2011.

4 Congregação originária da França, onde recebe o nome de Notre-Dame de Charité du Bon Pasteur D’Angers.

5 A proposta de um Reformatório centralizado para mulheres condenadas e processadas de diferentes estados brasileiros está presente no capítulo V do Anteprojeto do Código Penitenciário, publicado no Diário Ofi- 
Diário Oficial ${ }^{6}$, o governo teria pouquíssimo gasto com o estabelecimento prisional feminino, uma vez que este seria antes um local de receitas que de despesas, pois caberia às próprias internas a produção de alimentos, roupas e daquilo que precisassem para a sua subsistência. $\mathrm{O}$ pequeno número de mulheres condenadas e processadas era um fator positivo, pois facilitaria o trabalho das encarregadas pelos estabelecimentos. Apesar do apoio de governantes e do amparo legal ${ }^{7}$, os presídios femininos idealizados pelo Patronato das Presas tardaram a sair do papel, e, no final da década de 1930, quando finalmente o primeiro estabelecimento prisional surgiu, muitas foram as alterações em relação ao projeto proposto na década de 1920.

Datam de 1937 o Instituto Feminino de Readaptação Social no Rio Grande do Sul, de 1941 o Presidio de Mulheres de São Paulo e de 1942 a Penitenciária Feminina do Distrito Federal, em Bangu. O pequeno número de mulheres condenadas justificava, por vezes, o adiamento de soluções para a situação degradante na qual se encontravam. Algumas dessas instituições foram adaptadas em espaços já existentes, como no caso do Instituto de Readaptação Social do Rio Grande do Sul, bem como do Presídio de Mulheres de São Paulo. Já a Penitenciária de Mulheres de Bangu foi especialmente construída para tal finalidade.

Em relação a outros países europeus e americanos o Brasil estava atrasado, uma vez que muitos já tinham seus estabelecimentos prisionais femininos. $\mathrm{O}$ primei-

cial de 31 de agosto de 1933, pp. 17194 e 17195. No entanto, essa legislação não entrou em vigor.

6 Diário Oficial - 27 de julho de 1927, p. 16386 e seguintes.

$7 \quad$ No Relatório do Patronato das Presas, publicado no Diário Oficial de 27 de julho de 1927, há menções a leis e decretos que previam a construção de estabelecimentos prisionais femininos. Dentre estes, a Lei No 4212 de maio de 1921 que no inciso VI de seu artigo $3^{\circ}$ previa a construção de uma penitenciária agrícola para mulheres, nos limites do Distrito Federal, que deveria ser entregue à direção de "senhoras especialistas". Já o Decreto 16665 de 6 de novembro de 1924 reconheceu oficialmente o Patronato das Presas do Distrito Federal dando-lhe a atribuição de auxiliar a vigilância dos liberados condicionais. Por fim, o Código de Processo Penal do Distrito Federal, mandado executar pelo Decreto 16751 de 31 de dezembro de 1924, previa em seu artigo 549, inciso III, o cumprimento de pena na "Penitenciária Agrícola de Mulheres, logo que fôr installada, continuando, provisoriamente na casa de Detenção as mulheres condemnadas”. 
ro do qual se tem notícia na História ocidental data de $1645^{8}$. Denominado The Spinhuis, localizado em Amsterdã, na Holanda, era considerado uma instituição modelo, que abrigava mulheres pobres, desrespeitosas, criminosas, bêbadas e prostitutas, bem como meninas mal comportadas que não obedeciam aos seus pais e maridos. Era uma casa de correção e instituição prisional, voltada para o trabalho na indústria têxtil (ZEDNER, 1995, p. 329). Um letreiro no pórtico de estrada trazia o seguinte lema: Não Tenha Medo! Não queremos vingança para o mal, mas obrigá-lo a ser bom. Minha mão é severa, mas meu coração é bondoso (ZEDNER, 1995, p. 329). $\mathrm{O}$ modelo holandês de casas de correção pautadas no trabalho foi copiado em diferentes países europeus, como a Inglaterra, com trabalhos voltados tanto para a indústria têxtil - as internas costuravam e teciam -, quanto para a comunidade prisional, exercendo tarefas nas áreas de limpeza, cozinha e lavanderia. Segundo a criminóloga Lucia Zedner, muitas dessas casas de correção deturparam sua função inicial, sendo as mulheres aprisionadas obrigadas, pelos administradores, a se prostituírem, cenário comum em casas de correção europeias desde o século XVII. Há também relatos de aprisionamento de mulheres junto aos homens.

No século XIX, período no qual o debate acerca da necessidade de criação de instituições específicas para encarceramento feminino ganhou corpo em países como França, Inglaterra e Estados Unidos, as mulheres compunham um pequeno porcentual da população encarcerada, sendo 20\% na Inglaterra, entre 14\% e 20\% na França e entre 4\% e 19\% nos Estados Unidos. De acordo com Zedner, no século XIX, a segregação por sexo foi uma das maiores realizações da reforma penal em curso em alguns países (ZEDNER, 1995, pp. 329 a 333). Resgate da moral, da feminilidade e o aprendizado das tarefas femininas eram os principais objetivos dos que se dedicavam à causa das mulheres presas, sendo a presença de voluntárias de classe média, as "lady visitors" influenciadas pela militante Quaker inglesa Elisabeth Fry",

8 Há dados que apontam a criação do The Spinhuis em 1597, sendo 1645 o ano de construção de um prédio novo, erguido no mesmo local, após um incêndio em 1643. Fonte: http://didyouseethisinamsterdam.blogspot.com/2009/01/prison-gate-of-amsterdam-spinhuis.html, acesso em 01/07/2011.

9 Elisabeth Fry é considerada a grande mentora das instituições prisionais femininas tanto na Inglaterra quanto em outros países da Europa e nos Estados Unidos. Na primeira metade do século XIX, mulheres quaker 
fundamental na criação dos estabelecimentos prisionais femininos.

Nos Estados Unidos, a primeira prisão exclusivamente para mulheres, Mount Pleasant Female Prision, no estado de Nova York, foi estabelecida em 1835, tendo sido o único estabelecimento desse tipo até 1870, a partir de quando foram abertos vinte reformatórios até 1935, dentre eles os House of Shelter, no Estado de Michigan, Reformatory Institution, no Estado de Indiana e New York House of Refuge for Women. Já na Inglaterra, com o fim do envio de prisioneiros e prisioneiras para as colônias, em meados do século XIX, três estabelecimentos voltados para o aprisionamento feminino foram erguidos em Londres, na década de 1850: Millbank, Brixton e Fulham. Na França, as primeiras prisões separadas por sexo datam de 1820. De acordo com Zedner, dúvidas em relação ao modelo ideal de regime penitenciário a ser seguido nos presídios femininos se fizeram presentes à época da criação desses espaços, em especial se deveriam aplicar regimes de silêncio absoluto com celas individuais ou misto, que mesclava espaços e momentos de silêncio com o convívio em grupo. Na Inglaterra, optou-se pelo modelo de celas individuais, onde as mulheres ficavam a maior parte do tempo confinadas para evitar o convívio entre grupos de mulheres distintos ${ }^{10}$. Os reformadores penais ingleses concluíram que a natureza sedentária das mulheres facilitaria que passassem longo tempo em pequenas celas. $\mathrm{Na}$ França, apesar dos reformadores associarem a natureza feminina à sociabilidade, e, portanto à impossibilidade inata para o silêncio e isolamento completo, muitos advogavam pela necessidade de separação, para evitar as más influências das "corruptas" sobre as "inocentes" ${ }^{11}$, visão que acabou prevalecendo. Outros países adotaram o regime de isolamento, tendo este sido priorizado em grande parte da Europa ao longo do século XIX (ZEDNER, 1995, pp. 336 a 339).

Um dos objetivos do aprisionamento de mulheres era inculcar nas prisio-

de diferentes locais se engajaram em campanhas encabeçadas por ela em prol das mulheres presas. É de sua iniciativa a criação da Ladies Association for the Reformation of Female Prisoners, na Inglaterra, que posteriormente recebeu o nome de Ladies Society for the Reformation of Female Prisioners (Zedner, 1995, pp. 333 a 336).

10 Entende-se como grupos distintos aqueles formados por mulheres: de procedência social diversa; e/ou em distinto momento processual (condenadas ou processadas); e/ou agrupadas segundo o tipo de crime cometido.

11 A distinção entre os "tipos" de mulheres aprisionadas será aprofundada no capítulo 3. 
neiras sentimentos femininos e orgulho doméstico. Zedner cita um autor anônimo segundo o qual "uma mulher, ao adentrar uma prisão, deveria sentir que, por mais repleta de vícios que fosse sua vida passada, ela chegou a um lugar onde tem um caráter para recuperar e suportar"12 (ZEDNER, 1995, p. 341). As mulheres eram submetidas a grande vigilância e controle, mais que os homens, pois, além de terem de seguir as regras gerais do cotidiano prisional, deveriam aprender posturas e comportamentos femininos (ZEDNER, 1995, p. 342). Segundo a autora, havia em alguns presídios, como o do estado de Indiana, nos Estados Unidos, criado em 1874, uma tentativa de simular o ambiente doméstico, com "mulheres vestidas com vestidos acinturados, comendo em mesas cobertas com toalhas e decoradas com flores. O cenário doméstico permitia ampla oportunidade para treinar as internas nas tarefas de donas de casa, como cozinhar, limpar e servir" (ZEDNER, 1995, p. 354)

Os reformatórios femininos construídos nos Estados Unidos a partir da década de 1870 focaram, principalmente, a educação das mulheres para o lar, a vida em família e as tarefas femininas, objetivando a reinserção social das reclusas, seguindo propostas de um movimento de mulheres filantropas que reivindicava prisões que levassem em conta as peculiaridades femininas. Já na Europa, mudanças significativas no modelo de encarceramento ocorreram nas duas últimas décadas do século XIX, quando a medicalização do desvio, oriunda do avanço das ciências, em especial da psiquiatria, guiou o modelo de prisão terapêutica, que deveria ser voltada para o isolamento das pessoas perigosas do seio social, bem como para o tratamento das causas do desvio (ZEDNER, 1995, pp. 352 a 357).

Por fim, Zedner realça que houve, tanto na Inglaterra quanto nos Estados Unidos, um período de decadência das instituições prisionais femininas no início do século XX, atribuída, principalmente, a mudanças na quantidade e na qualidade da população prisional. Durante a Primeira Guerra Mundial, a política de aprisionamento de prostitutas para evitar que doenças venéreas se espalhassem na popula-

12 Nesta dissertação foram realizadas traduções livres do original para todas as citações de textos em inglês, espanhol e francês. 
ção masculina, bem como o aprisionamento de usuárias de drogas e alcoólatras levou para dentro das prisões mulheres estigmatizadas, consideradas pouco reformáveis, o que gerou um abandono por parte dos grupos de caridade e uma descrença no potencial reformador desses espaços. Nos Estados Unidos, o aprisionamento de mulheres por essas razões gerou o aumento da população carcerária feminina e desestabilizou os reformatórios, antes voltados para um público menor, com um trabalho mais personalizado. Outros fatores, como a depressão econômica de 1929, impediram a continuidade do projeto de reforma prisional e a manutenção do modelo personalizado dos reformatórios. Já na Inglaterra, uma queda no número de mulheres presas por volta dos anos 1930, possivelmente ocasionada por uma melhoria nas condições sociais da população, bem como pelo investimento em outras instituições que não as prisões para o tratamento de mulheres, gerou o fechamento de muitos reformatórios e o abandono, por parte das autoridades, desses espaços (ZEDNER, 1995, p. 357). Na América Latina países como Chile, Argentina, Peru e Uruguai ergueram seus estabelecimentos prisionais femininos antes do Brasil ${ }^{13}$.

Nas considerações escritas em 1941 por Lemos Britto - apresentadas ao então ministro da Justiça e Negócios Interiores, Alexandre Marcondes Campos -, acerca do Ante-Projeto de Regulamento da Penitenciária de Mulheres e do Sanatório Penal de Tuberculosos que estavam sendo construídos na capital federal, o autor reafirma a situação precária do aprisionamento de mulheres na cidade do Rio de Janeiro:

o que existe nesta Capital, como prisão de mulheres, é alguma cousa de oprobrioso e que faria corar a um burgo-pobre da velha Inglaterra. Trata-se, como Vossa Excelência sabe, de um pequeno barracão cimentado dos fundos da Casa de Detenção, gradeado à manei-

13 Tais instituições serão tratadas com detalhes no $4^{\circ}$ capítulo, em especial as argentinas e chilenas. 
ra de um xadrês das cadeias públicas, onde se acomodam as mulheres processadas e condenadas do Distrito Federal. (APB, 1942d, p. 27)

No mesmo documento Lemos Britto mostra um levantamento estatístico sobre o aprisionamento de mulheres no país, feito pelo Conselho Penitenciário do Distrito Federal, com a ajuda dos Conselhos Penitenciários Estaduais. Os dados foram coletados pelos Conselhos Estaduais em estabelecimentos das respectivas capitais e cidades do interior dos estados. Apesar de Lemos Britto apontar possíveis falhas estatísticas - alguns relatórios não diferenciam o número de condenadas e processadas, apresentando um total global de prisioneiras por estado; outros não explicitam claramente o número de mulheres presas no momento da pesquisa, mas tratam dos "últimos anos" - foi possível, a seu ver, traçar um panorama aproximado da quantidade de mulheres presas no país. Com as exceções dos estados do Mato Grosso e do Maranhão, que não enviaram os dados solicitados pelo Conselho Penitenciário do Distrito Federal, pôde-se apontar, dentre sentenciadas e processadas, cerca de 340 mulheres aprisionadas no país em 1941 (APB, 1942d, p. 27).

Estados como o Amazonas, o Espírito Santo e o Território do Acre não declararam mulheres em seus presídios. O Estado de Santa Catarina apresentou apenas uma presidiária, enquanto Piauí e Goiás indicaram três presas cada. O Ceará calculou cinco presas, o Paraná seis, e os estados do Rio Grande do Norte e Sergipe sete em cada um. Alagoas e Bahia apontaram ter, respectivamente, dez e onze presas em seus estabelecimentos prisionais. Dentre os Estados com o maior contingente criminal feminino estavam Rio Grande do Sul (68 mulheres encarceradas), Minas Gerais (58), São Paulo (46), Distrito Federal (34) e Pernambuco (30) (APB, 1942d, p.28).

Desagregando os dados quando possível, a pesquisa revela a existência de 165 condenadas e 77 processadas nas capitais, totalizando 242 mulheres. Já no interior dos estados havia 58 presas, o que totaliza 300 mulheres presas em todo o Brasil. Considerando uma margem de erro de $12 \%$ sobre esse total com o intuito de corrigir possíveis omissões, Lemos Britto afirma que à época havia menos de 400 mulheres presas no país. Segundo seus cálculos: "Isto dará uma proporção inferior a 
uma por cem mil habitantes tomando por base a população de 41 milhões, cálculo de 1939, e, possivelmente de uma por 400.000 mulheres adultas residentes no Brasil". Em comparação com os homens condenados e processados, o autor usa dados do Distrito Federal, apontando que havia nos presídios da capital do país cerca de 1500 homens presos, e 34 mulheres, o que daria uma proporção pouco maior que duas mulheres para cada cem homens (APB, 1942d, p.28).

Por fim, Lemos Britto em palestra denominada As Mulheres Criminosas e seu Tratamento Penitenciário, proferida em 1943, ressalta que a porcentagem de mulheres condenadas em todo o país era, em média, de 6\% da população masculina encarcerada. $\mathrm{O}$ autor afirmou que havia estados em que não existiam sequer mulheres cumprindo pena, e que “(...) São Paulo, Rio Grande, Minas Gerais, dada sua população e participação da mulher nas atividades econômicas, as tem em maior número" (LEMOS BRITTO, 1943, p. 9).

Os dados apresentados permitem contextualizar o cenário do aprisionamento feminino no Brasil desde o final do século XIX até o momento de criação dos primeiros presídios femininos no país, de modo a introduzir, com base em pesquisas realizadas no período, alguns elementos do cenário trabalhado nesta dissertação. Já os breves apontamentos sobre o aprisionamento feminino em países da Europa e nos Estados Unidos possibilitam situar o tema em um contexto mais amplo que o nacional. O presente trabalho resgata alguns aspectos da criação dos primeiros presídios femininos no Brasil. Retomando questões históricas, debates criminológicos, propostas e práticas de encarceramento, bem como discursos que evidenciam os lugares sociais ocupados por homens e mulheres no período, buscou-se recompor elementos relevantes que circundam essas instituições. 


\section{CONSIDERAÇÕES INICIAIS}

Pensadas e formadas pelas e para as pessoas, há, na base de cada instituição, ideologias, metas e ideais envolvendo suas razões de ser e as funções que deverá exercer. A presente dissertação buscou remontar o cenário que permitiu a construção das primeiras unidades prisionais femininas no Brasil, englobando elementos dos contextos legislativo e punitivo; expectativas sociais em relação à mulher e desvios de um modelo feminino padrão; classificações das mulheres delinquentes; e os projetos, perspectivas e práticas dos estabelecimentos prisionais para mulheres.

Pensar a edificação de instituições prisionais femininas implica verificar para quem tais instituições eram destinadas e o papel que deveriam cumprir intra e extramuros. Partindo do pressuposto de que a instituição cria o institucionalizado e vice-versa, uma vez que ela delimita quem são os que a comporão e de que forma esses devem reagir e interagir com os limites impostos, buscou-se, por meio da análise de registros institucionais, oficiais, discursivos, acadêmicos e legais relativos à criação dos presídios femininos no Brasil, na primeira metade do século XX, trabalhar o contexto que possibilitou a edificação dessas instituições. Quais os principais de- 
bates em torno das primeiras prisões femininas no Brasil; qual a função alegada para essa instituição e a quem, principalmente, ela estava voltada são as questões centrais que guiaram a pesquisa que originou a presente dissertação. Optou-se, para tanto, por identificar as instâncias e personagens que decidiram atentar para a delinquência feminina e como elas articularam discursos no investimento e autorização da criação destes estabelecimentos.

Privilegiou-se, inicialmente, uma contextualização histórica do momento punitivo, legislativo e político no qual se inseriram os primeiros presídios femininos no país. Em seguida, escolheu-se identificar quais modelos de "dever ser feminino" pautavam o ideário sobre a "boa mulher", para então delimitar os modelos "desviantes" do feminino, de modo a verificar se e/ou como tais estereótipos pautavam as classificações da criminosa e guiavam os "olhares" da justiça criminal. A quem os cárceres femininos eram destinados e quais eram as principais delineaçóes da delinquência feminina foi, igualmente, tema de análise. Por fim, explicitou-se como nesse momento específico - finais da década de 1930 e início da década de 1940 -, os presídios femininos foram estruturados de modo a abrigar mulheres consideradas delinquentes. Como deveriam funcionar esses estabelecimentos, qual deveria ser a função da pena para essas mulheres, bem como a quem caberia a tarefa de tutelar essas instituições em seus primeiros tempos foram igualmente pontos debatidos.

O Instituto Feminino de Readaptação Social em Porto Alegre, no Rio Grande do Sul, de 1937, o Presídio de Mulheres de São Paulo e a Penitenciária de Mulheres de Bangu, no município do Rio de Janeiro, inaugurados em 1942, por serem os primeiros estabelecimentos prisionais femininos no país, foram as três principais instituições analisadas. No projeto original desta pesquisa propôs-se delimitar o tema de modo a estudar a criação do Presídio de Mulheres, junto ao complexo do Carandiru em São Paulo, no ano de 1941. Supôs-se que tal delimitação não fosse um impedimento para a visualização de um panorama mais geral, uma vez que a ideologia da criação de instituições prisionais femininas baseou-se em pressupostos semelhantes nos diferentes estados da federação. No entanto, durante a pesquisa, verificou-se que o processo de criação dos estabelecimentos prisionais femininos se deu qua- 
se de maneira concomitante nos estados do Rio Grande do Sul, São Paulo e Rio de Janeiro, e que privilegiar um seria, para os propósitos do presente trabalho, deixar de lado pistas importantes de um processo mais amplo. O fato de o Rio de Janeiro ser a Capital Federal à época, e, portanto, abrigar a maioria dos órgãos federais oficiais, como o Conselho Penitenciário do Distrito Federal e a Inspetoria Penitenciária do Distrito Federal, justifica que grande parte da produção oficial, como revistas dos órgãos federais e pareceres, seja oriunda dessa cidade, sendo a reflexão sobre a criação dos presídios femininos no país menos concentrada em um só estabelecimento, mas transposta para todo o Brasil. Além disto, a Penitenciária de Mulheres de Bangu, no Rio de Janeiro, foi especialmente construída para ser um presídio feminino, ao contrário das outras que foram erguidas em prédios adaptados, sendo, portanto, os debates em torno de Bangu importantes para a análise dos moldes ideais de uma penitenciária feminina. Assim, optou-se por analisar o processo nacional de criação dos estabelecimentos prisionais para mulheres e não apenas o ocorrido no estado de São Paulo.

Como delimitação temporal, optou-se, além de um breve retorno à legislação e prática prisional do século XIX, por trabalhar as décadas de 1930, 1940 e 1950, período de edificação das primeiras prisões femininas no Brasil. Apesar das três primeiras unidades femininas datarem das décadas de 1930 e 1940, data da década de 1950 a maioria dos relatos e descrições do funcionamento dessas instituições. As estatísticas sobre criminalidade, detenções e condenações femininas utilizadas são igualmente dessas décadas.

\section{CONSIDERAÇÕES METODOLÓGICAS Pesquisa documental}

A ausência de uma etnografia nos moldes consagrados e tão detalhadamente tratados por Malinowski em Argonautas do Pacifico Ocidental não significa o abandono de uma metodologia fundamental à Antropologia, mas uma releitura do que seria a observação participante aplicada a fontes documentais. Malinowski privile- 
giava um estudo sincrônico das culturas, um registro do momento vivido. A valorização do "presente etnográfico" estava na ordem do dia da Escola Funcionalista, sendo fundamental a observação do funcionamento social em tempo real e sua descrição minuciosa. Era necessário vivenciar o cotidiano tribal para então cumprir o objetivo principal da pesquisa etnográfica que, segundo Malinowski seria: “(...) o de apreender o ponto de vista dos nativos, seu relacionamento com a vida, sua visão do seu mundo" (MALINOWSKI, 1984, pp. 33-34).

Giumbelli, ao questionar a indispensabilidade do trabalho de campo para a estruturação da Antropologia, ressalta que “(...) 'o objetivo fundamental da pesquisa etnográfica' deve ser buscado a partir de uma variedade de fontes, cuja pertinência é avaliada pelo acesso que propiciam aos 'mecanismos sociais' e aos 'pontos de vista' em suas 'manifestações concretas'”. O autor defende a tese de que a análise documental pode vir a ser mais importante que o trabalho de campo à medida que, em determinadas situações, documentos dizem mais ao antropólogo que a experiência in loco. Assim, ao explicitar as razóes que o levaram a privilegiar a pesquisa documental em detrimento da pesquisa de campo em determinado trabalho, justifica sua escolha: "a fonte textual não ganha privilégio por oposição ao trabalho de campo, mas pela razão de estarem nela inscritas as informações metodologicamente relevantes e socialmente significativas" (GIUMBELLI, 2002, p. 102).

Ainda para Giumbelli, "se na observação participante, o pesquisador deve deixar seus 'nativos' falarem, no uso das fontes textuais ele deve lidar com o que já foi dito" (GIUMBELLI, 2002, p. 102). Nesse sentido, parte-se do pressuposto que para a Antropologia, como para a História e as demais Ciências Sociais, um documento não possui status de verdade, mas é passível de interpretação e de avaliação, dado que é uma produção humana, datada e inserida em um determinado contexto social, que certamente reflete aquilo oficialmente registrado. Dessa forma, o documento adquire o status de um informante que, de alguma maneira, dialoga com o pesquisador, permitindo antes uma relação de interpretação e apreciação crítica que uma mera constatação de fatos oficiais. A análise documental, nesses termos, pode ser considerada uma meta-análise, pela qual se observa algo que é fruto de reflexões anteriores. 
A pesquisa de Ana Lúcia Pastore Schritzmeyer Sortilégio de Saberes: curandeiros e juizes nos tribunais brasileiros (1900-1990) é um exemplo de pesquisa documental em Antropologia que transita entre as Ciências Sociais e o Direito, na qual há uma meta-análise de acórdãos que versam sobre o crime de curandeirismo no Brasil. A autora, ao introduzir a metodologia utilizada em sua pesquisa, ressalta que:

valemo-nos, para tanto, da tradicional postura antropológica que observa o outro para conhecê-lo e conhece-o para entender a lógica pela qual ele dá sentido ao mundo. Deslocamos, porém, a experiência do trabalho de campo antropológico, que põe frente a frente observador e observado, para uma experiência de trabalho documental, que distancia carnalmente o estudioso de seu objeto, mas o aproxima de suas representaçôes escritas e de seus 'rastros' oficiais (SCHRITZMEYER, 2004, p. 15).

Ao refletir acerca do trabalho realizado pela antropóloga Ruth Landes ao longo dos seus últimos vinte anos de vida, durante os quais organizou minuciosamente os seus arquivos pessoais, Olívia da Cunha analisou a relação entre a Antropologia e os arquivos documentais. A autora ressalta o menosprezo que a Antropologia apresentou em diferentes momentos de sua trajetória para com outros tipos de pesquisa que não aquelas que envolvessem pesquisadores e pesquisados em relações sincrônicas, interpessoais e participativas. Em suas palavras,

(...) apesar da familiaridade da Antropologia com os arquivos, a relação entre ambos esteve sujeita a diferentes apropriações. A identificação da pesquisa em arquivos com as práticas antropológicas, entre elas a pesquisa de campo e a produção de etnografias, permanece sendo alvo de tensão. Tem sido associada à impossibilidade de estar lá e a formas secundárias de contato entre observadores e 'nativos' mediadas por camadas de interpretação intransponíveis e contaminadas. Descrever e interpretar a partir de informações contidas em documentos caracterizaria uma atividade periférica, complementar e distinta da pesquisa de campo e suas modalidades narrativas. Assim, a presença do arquivo na prática antropológica ou está afastada temporalmente daquilo que os antropólogos de fato fazem 
caracterizando a prática dos chamados antropólogos de gabinete — ou constitui marcadores fronteiriços da Antropologia com outras disciplinas - uma vez vinculados à prática dos historiadores, museólogos e arquivistas (CUNHA, 2004, pp. 292 e 293).

De fato, etnografar arquivos é estabelecer um diálogo necessário entre a historiografia e a etnografia, permitindo trânsitos presentes, mas menos evidentes, na observação participante. Se nas sociedades ocidentais a cronologia seria "nossa cosmologia particular" (SCHWARCZ, 2005, p. 126), pesquisar registros de tempos passados seria uma forma de colocar tempos em diálogo, contrastando passado e presente. Se, como ressaltou Lévi-Strauss, somos uma sociedade a favor da História e a temos como categoria explicativa, a análise de fatos passados serve como ponte para compreensão de fatos presentes (SCHWARCZ, 2005, p. 120). Estabelecer diálogos com a História é dialogar com o nosso próprio tempo.

Os arquivos são espaços privilegiados de registro em uma sociedade cuja cosmologia está centrada em uma perspectiva cronológica. Considerando que a Antropologia deve ser utilizada para problematizar conceitos e "verdades" que estão naturalizados, em uma pesquisa documental isso significa, mais uma vez, dialogar com fontes para conseguir identificar o que elas omitem, ressaltam e apresentam como dados oficiais.

A pesquisa documental pode ter diferentes propósitos, evidentemente, segundo os objetivos do trabalho que se pretende realizar. Dentre eles é possível que o pesquisador busque averiguar quem são os principais atores que encabeçam determinado processo oficializado nos documentos institucionais. Considerando que a instituição é formada por pessoas, possíveis pistas e respostas sobre quem são os sujeitos-chave e qual a sua contribuição para determinado processo oficial podem estar presentes nos documentos pesquisados. Na pesquisa documental, o olhar antropológico permite que o documento seja tratado como um interlocutor, ao qual perguntas são feitas.

Assim, no caso da pesquisa em curso, alguns atores são de extrema relevância para a recomposição do cenário punitivo nacional e para a análise do que estava em 
jogo na edificação e no dia a dia dos presídios femininos brasileiros nos seus primeiros anos. Não só os juristas e penitenciaristas da época são interlocutores privilegiados, mas também criminólogos com os quais dialogavam e as Irmãs da Congregação de Nossa Senhora da Caridade do Bom Pastor d' Angers, responsáveis pela administração de alguns estabelecimentos prisionais femininos em suas primeiras décadas.

Investigar esses atores é importante para compreender partes significativas do processo de edificação dos presídios femininos no país, afinal as instituições são formadas por pessoas que pensam, decidem, comandam e as vivenciam. Quem eram, o que liam, qual a sua formação educacional, quais cargos ocupavam, o que produziram oficialmente, se transitavam ou não pelas academias da época, com quais escolas dialogavam - são questões que devem ser levantadas, para que seja possível mapeá-los.

Segundo Lilia Schwarcz ${ }^{14}$ é importante fazer boa Antropologia sem fazer má História, sendo fundamental transitar pelas disciplinas utilizando o que cada uma tem de melhor a oferecer - incluindo não somente as discussões teóricas produzidas em cada campo, mas também os métodos e técnicas de pesquisa. Se cada disciplina "conquistasse" territórios metodológicos ou temáticos como sendo seus, as investigações seriam cada vez mais limitadas e menos reflexivas. Imagine as análises de fontes documentais pertencendo apenas à História, a observação participante à Antropologia, o método quantitativo à Sociologia? Haveria, indubitavelmente, uma grande perda no potencial analítico e crítico das ciências humanas. Esse trânsito por disciplinas e pelas fronteiras disciplinares não significa negar suas delimitações próprias, pelo contrário, a existência das disciplinas depende dos objetos de estudos, de sua delimitação e do referencial analítico e teórico utilizado. Significa, isso sim, assumir que os temas e os métodos podem ser compartilhados e (re) significados.

\section{Documentos e materiais pesquisados}

Para tratar dos temas propostos, optou-se por analisar documentos legais,

14 Em fala na aula da disciplina Metodologia de Projeto II, ministrada pela Profa. Dra. Ana Lúcia Pastore Schritzmeyer, no segundo semestre de 2009. 
como decretos, anteprojetos de leis, regulamentos e leis vigentes; artigos e relatórios publicados em periódicos temáticos; obras de autores que, em alguma medida, trataram do tema; discursos proferidos por atores envolvidos na elaboração das instituições em questão; cartas e outros relatos das Irmãs do Bom Pastor d' Angers; fotografias de diversas origens; anuários do Serviço de Estatística Policial do Estado de São Paulo; bem como a realização de entrevistas. A busca pela documentação foi feita, dentre outros, em bibliotecas, arquivos, museus e na internet. Merecem destaque a Biblioteca Nacional; Bibliotecas da Faculdade de Direito da Universidade de São Paulo; Biblioteca da Pontifícia Universidade Católica de São Paulo; Secretaria de Segurança Pública do Estado do Rio Grande do Sul; Museu Penitenciário de São Paulo; e Centro de Estudos e Pesquisas da Escola de Gestão Penitenciária do Estado do Rio de Janeiro.

Em um primeiro momento fez-se um levantamento exploratório de todos os periódicos brasileiros que tratavam de criminologia, penitenciarismo, direito penal, medicina forense e temas correlatos. A seguir, fez-se uma triagem por data, escolhendo aqueles cujos primeiros volumes foram lançados entre 1920 e 1940. Foram selecionados os seguintes periódicos: Revista de Criminologia e Medicina Legal, Revista de Criminologia, Revista Brasileira de Criminologia e Direito Penal, Revista Penal e Penitenciária, Arquivos Penitenciários do Brasil e A Estrela - Orgão da Penitenciária Central do Distrito Federal. Então, foram reunidos todos os periódicos ${ }^{15} \mathrm{e}$ realizada uma detalhada análise de seus sumários, de modo a selecionar artigos, casos, debates, análises doutrinárias, relatos, apreciações acerca da legislação, análise de casos criminais e jurisprudências que tratassem dos seguintes temas: história da criminologia no Brasil, sistema carcerário nacional, teoria criminológica, encarceramento feminino, presídios femininos, mulheres presas, crimes cometidos por mulheres e mulher e sociedade. Privilegiou-se dois periódicos para uma análise mais aprofundada, uma vez que ambos, cada um à sua maneira, tinham a questão penitenciária

15 A coleção quase completa da revista A Estrela e alguns volumes dos Arquivos Penitenciários do Brasil foram encontrados na Biblioteca Nacional, tendo sido os conteúdos desses periódicos microfilmados para a análise aprofundada que o presente trabalho exigiu. 


\section{aroutivos peittriguírios DO BRASIL}

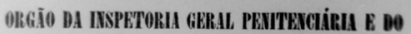
COSSELHO PENITETCLIRIO DO DISTRITO FEDERIL

ANO II - N. 4

fo TRIUESTRE OF 19!1

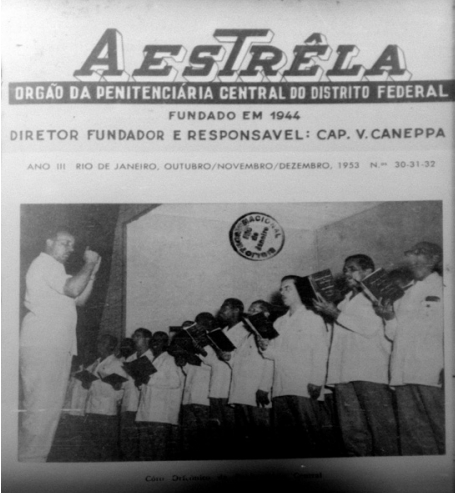

(5) हु)

ÓRGÃO DA PENITENCIÓRIA CENTRAL oO DISTRITO FEOERAL fundado em 1944

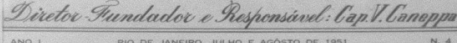

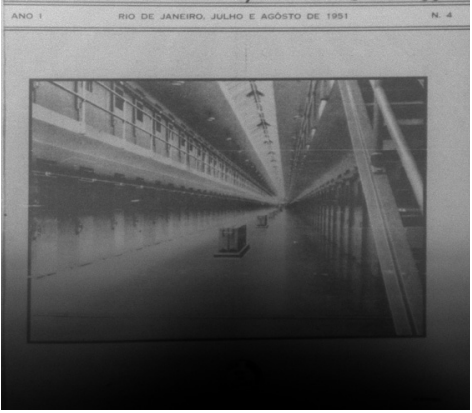

AESTREIA

DRGAOO DA PENITENCIÁRIA CENTRAL DO DISTRITO FEDERAL FUNDADO EM 1944

DIRETOR FUNDADOR E RESPONSAVEL: CAP. V.CANEPPA

ANO II

RIO DE JANEIRO, OUTUBRO 1952

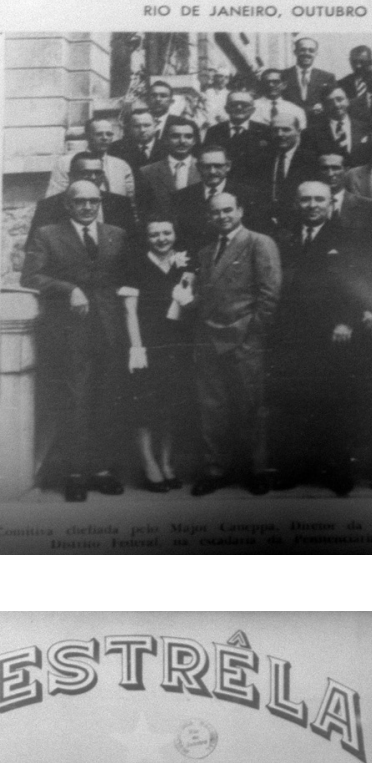

ÓRGÃO DA PENITENCIŔRIA CENTRAL DO DISTRITO FEDERRL f'undado em 1944

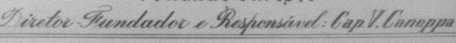

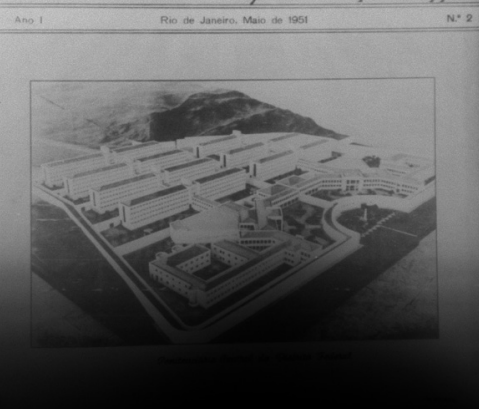

ALGUNS FRONTISPÍCIOS

D' A ESTRELA E DOS ARQUIVOS

PENITENCIÁRIOS DO BRASIL.

SEMPRE ILUSTRADAS COM

FOTOGRAFIAS OU DESENHOS,

AS CAPAS D' A ESTRELA

REFLETEM O "ENTUSIASMO

PENITENCIÁRIO” DAS

DÉCADAS DE 1940 E 1950 
como tema central, bem como apresentavam conteúdo referente a questões envolvendo criminalidade feminina e instituições prisionais para mulheres: os Arquivos Penitenciários do Brasil e a revista $A$ Estrela. Foram analisados também artigos esparsos publicados em periódicos da época, como os Arquivos da Polícia Civil de São Paulo, a Revista Penal e Penitenciária e os Arquivos da Sociedade de Medicina Legal e Criminologia de São Paulo.

Publicação considerada "Órgão do Conselho Penitenciário do Distrito Federal e da Inspetoria Geral Penitenciária ${ }^{16}$ ", pertencente ao Ministério da Justiça e Negócios Interiores, a Arquivos Penitenciários do Brasil foi impressa pela primeira vez em 1940. Catalogada na Biblioteca Nacional, sob os seguintes assuntos: I) prisões; II) crime e criminosos; III) direito penitenciário; e IV) direito penal; teve ao todo doze volumes publicados, sendo o primeiro de 1940 e o último de $1958^{17}$.

Seus primeiros redatores - muitos deles mantidos na elaboração da maioria dos volumes - foram: Lemos Britto, então presidente do Conselho Penitenciário do Distrito Federal, inspetor geral penitenciário, ex-professor de Direito nas faculdades de Direito e de Engenharia da Bahia, contratado da Faculdade Nacional de Direito e presidente da Sociedade Brasileira de Criminologia; Roberto Lyra, livre-docente da Faculdade Nacional de Direito, professor catedrático da Faculdade de Direito do Rio de Janeiro, promotor de justiça e conselheiro; Heitor Carrilho, conselheiro, livre docente na faculdade Nacional de Medicina, professor Catedrático da Faculdade Flu-

16 O Decreto No 16. 665, de Novembro de 1924, criou o Conselho Penitenciário. Cândido Mendes, seu primeiro presidente, ressaltou em discurso a importância da criação do Conselho, pois "no Brasil, mais que em nenhum outro país, infelizmente, não temos regime penitenciário. Fora o que verificara entristecido o Dr. Lemos Britto, há pouco incumbido pelo governo de percorrer as prisões do Brasil, apresentando trabalho notável, tanto na sua parte teórica, quanto na parte prática, de observações diretas feitas pelo ilustre jurista. Por esse trabalho, se verá que nos envergonha o que está sendo produzido em matéria penitenciária no Brasil. Forçoso é criar para nós, atendendo à índole dos nossos criminosos, um regime especial” (p. 264). O Conselho tinha como função elaborar propostas que viabilizassem a reforma carcerária, bem como "verificar a conveniência da concessão de livramento condicional; tratar de liberdade vigiada (em caso de menores delinquentes); manifestar-se sobre graça, indulto e comutação de pena". Já a Inspetoria Penitenciária foi criada pelo Governo Federal que, "com o intuito de obter recursos financeiros para a efetivação das reformas penais, criou o selo penitenciário, bem como a inspetoria geral, por decreto $\mathrm{n}^{\circ} 24.797$ de 14 de julho de 1934 . O decreto 1.441 de 8 de fevereiro de 1937 regulamentou esse decreto, tratando da organização da inspetoria" (Volume I, Números 1 e 2, $1^{\circ}$ e $2^{\circ}$ trimestre de 1940). 17 São eles: 1) - 01/1940 a 06/1940; 2) - 07/1940 a 09/1940; 3) - 10/1940 a 12/1940; 4) - 01/1941 a $03 / 1941 ; 5)$ - 04/1941 a 09/1941; 6) - 10/1941 a 12/1941; 7) - 01/1942 a 06/1942;08) - 07/1942 a 12/1942; 09) - 01/1943 a $12 / 1943$; 10) - 01/1944 a 12/1944; 11) - 01/1945 a 12/1945; 12) - 01/1958 a 12/1958. 
minense de Medicina e Diretor do Manicômio Judiciário; e Armando Costa, secretário geral do Conselho Penitenciário e professor da Faculdade de Ciências Políticas e Econômicas. De acordo com o editorial do primeiro volume, a revista objetivava

(...) reunir e difundir toda a matéria concernente ao direito e à prática penitenciária através dos estudos doutrinários, dos pareceres dos conselhos, dos conselhos e acórdãos dos tribunais, bem como a familiarizar os nossos administradores de estabelecimentos penais e especialistas da matéria em apreço com as leis e realizações dos demais povos (APB, 1940, p. 22)

Ainda segundo o editorial, o periódico deveria conter "artigos de doutrina e crítica, conferências, pareceres, sentenças e acórdãos, resoluções governamentais, noticiário relativo aos estabelecimentos penitenciários nacionais e estrangeiros, projetos e planos, plantas e fotografias e resenhas bibliográficas" (APB, 1940, p. 22). Distribuída para os Conselhos Penitenciários estaduais, para estabelecimentos prisionais, para faculdades de Direito e Medicina e diversos órgãos públicos, a publicação divulgava os trabalhos dos Conselhos e das Inspetorias brasileiros, em especial aqueles do Distrito Federal. Apesar de se tratar de um periódico vinculado a um órgão oficial, foi grata a surpresa de perceber que não tem um ponto de vista único e que um mesmo volume contém artigos que são contraditórios no plano teórico, mostrando encampar ideias conflitantes. Ainda, os pareceres sobre alguns presídios brasileiros são extremamente críticos, mostrando a situação dos cárceres nacionais.

Questôes de fundo, tanto teóricas quanto práticas, ocupavam espaço privilegiado da revista: qual seria a melhor teoria para explicar o delito; se deveria ou não haver um foco especial no delinquente; se seria correta a abordagem sociológica do crime; qual a fórmula ideal para o bom funcionamento dos estabelecimentos prisionais, dentre outras. Em relação a esta pesquisa, essas discussões de fundo chamam a atenção, na medida em que traçam um panorama do debate e da prática prisional na época, bem como abordam a situação prisional feminina. 
A Estrela ${ }^{18}$, boletim mensal da Penitenciária Central do Distrito Federal, à qual estava submetida a Penitenciária de Mulheres de Bangu, contém artigos de funcionários, presidiários, juristas, jornalistas e outros. Foi lançado pela primeira vez em outubro de 1944, na primeira gestão de Victorio Caneppa como diretor da Penitenciária Central do Distrito Federal. Foi um jornalzinho de 1944 e 1945 e durante os anos de 1946 a 1950 não circulou, pois foi o período em que outro diretor substituiu Caneppa, que retomou o cargo em 1950. Extremamente centrado na figura do diretor, o boletim assume o papel de cartão de visitas da penitenciária, que aparece sempre como local humanizado, centrado na recuperação social do detento. $\mathrm{O}$ tom da revista e a maneira como o diretor é retratado pode ser percebido pelo texto do editorial de maio de 1951:

A ESTRELA esteve presa também. Agora que já crescemos, já evoluímos, somos uma revista! (...) A ESTRELA, entretanto, não tinha morrido, porque ainda está vivo Victório Caneppa, o astrônomo que a descobriu. Ele usa um possante telescópio, e não nos admiremos se um dia chegarmos a ser um SOL, porque o SOL é uma estrela (AE, maio de $\left.1951, \mathrm{~s} / \mathrm{p}^{19}\right)$

Periódico comercializado com o objetivo de arrecadar dinheiro para dar assistência social à família do encarcerado, era enviado para assinantes pelos Correios e/ou vendido individualmente. Além disso, trazia em suas páginas anúncios de pro-

18 Foram analisados todos os 24 volumes presentes no acervo da Biblioteca Nacional, que agrega quase todas as publicações de $A$ Estrela. São eles: Ano II, 31 de janeiro de 1945; Ano II, 30 de junho de 1945; Ano II, 30 de novembro de 1945; Ano II, 24 de dezembro de 1945; Abril de 1951; Edição Especial sobre a Penitenciária Central; Ano 1, junho de 1951, No3; Ano 1, outubro de 1951; Ano 1, novembro e dezembro de 1951 ( ${ }^{\circ}$ 7 E 8), ano I; Ano I, janeiro de 1952, № 9; Ano II, fevereiro e março de 1952, № 9; Ano II, maio e junho de 1952, No 13 e 14; Ano II, julho e setembro de 1952, No 15 e 17; A Estrela, ano II, Rio de Janeiro, outubro de 1952, No 18; Ano II, novembro/dezembro de 1952, No 19 e 20; Ano III, Janeiro/fevereiro de 1953, No 21 e 22; Ano III, março/abril de 1953, No 23-24; Ano III, maio/junho de 1953, No 25 e 26; Ano III, julho/agosto/setembro de 1953, No 27,28 E 29; Ano III, /novembro/dezembro de 1953, No 30,31 E 32; Ano IV, Rio de Janeiro, janeiro e fevereiro de 1954, No 33 e 34 Ano IV, março, abril e maio de 1954, No 35, 36 e 37 ; Ano IV, junho e julho de 1954, No 38 e 39; Ano V, agosto a fevereiro de 1954/1955, No 40/46.

19 Alguns documentos pesquisados, em especial $A$ Estrela, por vezes não têm números de páginas, seja porque estão apagadas, ou por não terem sido numeradas. 
dutos - como vassouras, roupas e refrigerantes. Poucos artigos científicos reproduzidos na revista dividiam espaço com colunas sobre literatura, páginas de jogos e passatempos, notícias sobre o sistema prisional, descrição de eventos ocorridos na penitenciária e fotografias de ambientes prisionais, debates jurídicos, notícias esportivas, discursos de autoridades e anúncios. Quase todos os volumes apresentavam pedidos de colaboração de artigos para estudantes de Direito e profissionais da área, bem como para radialistas esportivos e outros. Era editada e impressa pelo jornal carioca $O$ Globo.

"Dar voz" ao preso era uma das bandeiras da revista, que tinha muitos textos escritos por presidiários, em geral assinados com suas iniciais e o número de suas identidades prisionais. "A Estrela tem a colaboração dos sentenciados que abrem suas almas, contam suas esperanças, tristezas e recordações", ressalta um dos inúmeros trechos sobre a participação direta dos detentos (AE, nov/dez de 1952, s/p). Um editorial de 1944 afirma que:

fundado por Victório Caneppa, o dinâmico diretor da Penitenciária Central do Distrito Federal, circula hoje, mais um número de "A Estrela" mensário que se propõe a acolher e defender os interesses e aspirações dos sentenciados. Como acertadamente disse Roberto Lyra, em lapidar conceito emitido nas colunas desse jornal, a falta de um órgão nesses moldes era lacuna que não mais podia substituir. Quem melhor que o próprio encarcerado poderá indicar aquilo de que mais carece? Para que legislar, decretar; para que conferências penitenciárias se àquele mais fundamentalmente visado por essas medidas é recusado o direito de falar, e quando os seus mais justos anseios devem ser recalcados? Nome mais sugestivo não pudera ser dado a esse periódico: "estrela" evoca alegria, um raio de luz nas trevas, esperança em melhores dias. (AE, jan de 1945, p.2)

Em 1951, um artigo que tratava do primeiro número da revista, ao remontar à fundação de $A$ Estrela e sua razão de ser, explica o nome dado à revista e reverencia figuras como Caneppa e Getúlio Vargas, em um tom próprio da maioria das colunas publicadas: 
ao ter a feliz iniciativa de suprimir a ignomínia que representava o número ostensivo no uniforme dos sentenciados da Penitenciária Central por uma estrela correspondente ao grau de comportamento de cada um - ótimo, bom e regular - talvez estivesse muito longe o seu diretor, o digno $1^{\circ}$ tenente do glorioso exército nacional, Victório Caneppa, de pensar na simpática afinidade que essa tão oportuna medida tinha não só para com o mais impressionante passado que enriqueceu a história, sagrada, como a própria natureza que nos colocou sob o auspício da formosa constelação do Cruzeiro do Sul, e ainda nos nossos tempos, da bela estrela que conduziu o maior estadista produzido pelo Brasil, à segura conquista de sua verdadeira e mesmo assombrosa propriedade. Sim, foi aos reis magos que a Estrela do Oriente conduziu ao encontro daquele que devia ser o Apóstolo Supremo do Bem, personificado no amor e na caridade - o meigo Jesus, o Cristo Redentor; foi ao nosso rico, generoso e tão cobiçado Brasil que o Cruzeiro do Sul quis servir de teto, e foi à boa estrela do grande presidente Vargas que o destino confiou: a descoberta e o aproveitamento das nossas incalculáveis riquezas sub-solares; a marcha para o Oeste e o povoamento dos Sertões; as modernas conquistas que, pondo a greve fora da Lei, congraçaram os elementos do trabalho com as classes conservadoras, a humanização da justiça e o amparo e tratamento condigno dos infelizes e deserdados da sorte que outrora, na expressão da justa revolta do ex-ministro da justiça, o grande jurista Dr. Francisco de Campos - "eram os mortos vivos"! (Abril de 1951, s/p)

A religião e a fé sempre aparecem como elementos essenciais à recuperação do condenado e as metáforas bíblicas, como as presentes no trecho acima, são recorrentes. A revista tinha um objetivo claro de propagandear o trabalho praticado na penitenciária, passando a imagem de um local humano, limpo, bem cuidado, respeitado e "civilizado". A própria proposta de "dar voz" ao encarcerado era uma forma de mostrar à comunidade que na Penitenciária Central do Distrito Federal o presidiário era respeitado, ao ponto de poder se comunicar com o mundo exterior por meio de um jornal. O tom festivo com o qual os eventos ocorridos na Penitenciária são noticiados é um exemplo da maneira como se queria mostrar esse espaço. Campanhas 
em prol da família do detento, peças teatrais e apresentações da banda penitenciária; competições de futebol entre os times da penitenciária e entre estes e times externos; festas e cerimônias que contavam com a presença de visitantes e autoridades - todos os eventos recebiam grande destaque nas páginas d'A Estrela.

A presença das mulheres presas no periódico é bem menor que a dos homens. $\mathrm{O}$ fato de a revista ser produzida na penitenciária masculina, sede da diretoria e da administração geral das unidades ligadas à Penitenciária Central do Distrito Federal ${ }^{20}$ justifica, em parte, a pouca participação feminina. Além disso, a unidade feminina era submetida à direção geral, mas, internamente, era administrada pela Congregação das Irmãs do Bom Pastor d'Angers, o que, em certa medida, isolava a unidade feminina das demais. A partir da edição de junho de 1951, uma presidiária passou a contribuir para $A$ Estrela - Dinoráh, presa nº370 - escrevendo alguns poemas ${ }^{21}$ e notícias sobre a Penitenciária Feminina. Apesar da pouca participação das mulheres na revista, há bastante material sobre a unidade feminina em $A$ Estrela: notícias sobre festas na penitenciária, inaugurações de novos espaços, visitas de autoridades e estudantes, aniversário da Madre superiora, descrições do prédio e do funcionamento da penitenciária - material rico para a presente análise.

É notório o fato d'A Estrela ser uma revista parcial, que nunca critica o sistema prisional, que vangloria a figura do diretor Caneppa e tem como função principal apresentar uma imagem específica de um ambiente prisional humanizado. No entanto, isso não invalida o uso, no presente trabalho, de conteúdos da revista, em especial das descrições e relatos sobre a Penitenciária de Mulheres de Bangu, uma vez que a forma como esse espaço é mostrado é de suma relevância para apontar quais elementos foram escolhidos para serem destacados na revista, bem como qual era o ideal de cárcere feminino que se queria compartilhar intra e extramuros.

20 Ligadas à Penitenciária Central do Distrito Federal estavam as seguintes unidades: Penitenciária de Mulheres de Bangu e o Sanatório Penal de Bangu (chamados juntos de "setor Bangu"). A Penitenciária Central situava-se na cidade do Rio de Janeiro, e o "setor Bangu" no distrito de Bangu, inaugurados em 1942, a 45 quilômetros da capital.

21 Um deles, intitulado "Pedrinha de Sal" está transcrito no quarto capítulo deste trabalho. 
É importante mencionar que as seleções dos artigos publicados em periódicos são marcadas por filtros que devem ser levados em consideração. $\mathrm{O}$ fato dos $A r$ quivos Penitenciários do Brasil serem publicados por um órgão oficial representa um primeiro filtro para o tipo de debate que poderia ser incluído na revista. Assim, não se trata de um periódico que reflete o cotidiano prisional, ou as vivências dos funcionários do sistema. Trata-se de um espaço no qual são publicados pareceres feitos por funcionários da inspetoria e artigos escritos por juristas e por diretores de instituições prisionais. Já $A$ Estrela, que pretende ser a "voz dos sentenciados", é na verdade a "voz permitida aos sentenciados", pois não mostra contradições e críticas ao sistema, mas uma "voz pacificada" de um preso feliz com a possibilidade de estar em um lugar que lhe permitirá uma "reintegração social digna". Assim, tem-se consciência de se estar analisando periódicos com linhas editoriais específicas e objetivos específicos, o que não só valida a análise sobre o contexto e a criação dos presídios femininos no Brasil, como possibilita o exame desse cenário por meio de atores diretamente envolvidos no processo, como é o caso dos inspetores e conselheiros penitenciários, bem como pela ótica de pessoas de dentro do sistema prisional, que mostram esse espaço da forma como se gostaria que ele fosse visto.

No material analisado, principalmente nos textos dos Arquivos Penitenciários do Brasil, foi possível verificar que a década de 1940 foi extremamente significativa para a criminologia e a prática penitenciária brasileira, estando esse contexto presente nas páginas do periódico. Data do primeiro ano da referida década a promulgação do Código Penal; de 1941 a promulgação do Código de Processo Penal e o decreto de criação do Presídio de Mulheres de São Paulo; de 1942 a inauguração do Instituto de Biotipologia na Penitenciária do Estado de São Paulo e a inauguração da Penitenciária de Mulheres do Distrito Federal; ocorreram, ainda, ao longo da década a reforma e construção de diversas penitenciárias nos estados brasileiros e um aprofundado debate sobre reforma prisional e humanização penitenciária. A efervescência do debate penitenciário marca as páginas dos Arquivos.

Além dos periódicos, outros documentos foram examinados. Dentre eles o Guia das Internas da Penitenciária de Mulheres do Distrito Federal; inúmeras obras 
de Lemos Britto, como A Questão Sexual nas Prisões, de 1934, Adultério, de 1933 e Os Systemas Penitenciários do Brasil, de 1924, além de palestras e discursos do jurista; Doutrinas jurídicas do período, como Novo Direito Penal de Roberto Lyra; a obra $A$ Educação da Mulher, do higienista Afrânio Peixoto; duas obras sobre a Congregação Nossa Senhora da Caridade do Bom Pastor d'Angers, escritas, respectivamente, por uma Irmã e uma simpatizante da Congregação; Diários Oficiais; e obras do antropólogo criminal Cesare Lombroso, em especial La Donna Delinquente, la Prostituta e la Donna Normale.

Com o objetivo de agregar material e histórias sobre os estabelecimentos prisionais, duas entrevistas foram realizadas, sendo a primeira com Maria da Penha Risola Dias, diretora da Penitenciária Feminina de Sant'Anna entre 2005 e 2008 (e de outros estabelecimentos prisionais femininos) e funcionária do sistema prisional do estado de São Paulo desde a década de $1970^{22}$; e a segunda com a Irmã Zulma do Amaral Goulart, atual provincial da Congregação Nossa Senhora da Caridade do Bom Pastor d'Angers no Brasil. As entrevistadas disponibilizaram fotografias, livros e outros documentos referentes aos estabelecimentos prisionais e à Congregação ${ }^{23}$.

Entre as obras citadas na bibliografia, dois trabalhos sobre aprisionamento feminino foram referências importantes para a presente dissertação: Origens da Prisão Feminina no Rio de Janeiro, de Elça Mendonça Lima; e Prisioneiras - vida e violência atrás das grades, de Bárbara Musumeci Soares e Iara Ilgenfritz. A primeira, publicada em 1983, apresenta uma análise aprofundada da criação da Penitenciária de Mulheres do Distrito Federal e utiliza, além de outros documentos, o periódico $A$ Estrela. Já o segundo, de 2002, traz um capítulo que trata do histórico da prisão feminina no Rio de Janeiro, e utiliza, além de outras referências, a obra de Elça Mendonça Lima.

22 Entrevista realizada em 31 de maio de 2010 na Secretaria de Administração Penitenciária do Estado de São Paulo, no bairro do Carandiru.

23 Entrevista realizada em 07 de janeiro de 2011 na sede da Congregação em São Paulo, no bairro da Aclimação. 


\section{Fontes visuais}

Por fim, vale ressaltar o uso de fotografias como fontes documentais visuais utilizadas neste trabalho. Oriundas de diferentes acervos e/ou copiadas dos periódicos analisados, as fotografias que, na sua linguagem própria, são fundamentais à análise do objeto proposto, permitiram observar elementos imperceptíveis por outros meios. Quatro grupos distintos de fotografias compõem esta dissertação. São eles: I) fotografias de registro criminal possivelmente das primeiras internas do Presídio de Mulheres de São Paulo; II) imagens presentes nos periódicos analisados, em geral ilustrando artigos sobre o tema em análise, publicadas em volumes das décadas de 1940 e 1950; III) fotografias do Presídio de Mulheres de São Paulo; IV) e conjunto de imagens da Penitenciária Talavera Bruce e do Sanatório Penal, no Rio de Janeiro;

O primeiro conjunto foi encontrado no Museu Penitenciário Paulista ${ }^{24} \mathrm{em}$ março de 2011, em álbuns sem insígnia específica. Considerando os números de identificação pregados nas roupas das fotografadas e o uniforme utilizado, é possível supor que são registros das primeiras presas do Presídio de Mulheres de São Paulo. Em geral havia em cada página dos álbuns 12 fotografias, assim distribuídas: um retrato de frente e outro de perfil da presidiária, com roupas próprias e, ao lado, um retrato de frente e outro de perfil da mesma com uniforme do presídio, cabendo em cada página três séries dessas, de três diferentes mulheres. São fotografias classificatórias ou tipológicas, utilizadas pela antropometria desde o final do século XIX, com o enquadramento padronizado, de frente e de perfil dos indivíduos, que, segundo Olivier Lugon "encarnou por décadas a cientificidade da fotografia" (2007, p. 293). Ao todo foram encontradas fotografias dos registros de 51 mulheres. Optou-se por fotografar as folhas desses álbuns de modo a reproduzi-las no trabalho. Tais imagens permitiram análises sobre a especificidade deste tipo de representação documental, em que se pode interpretar a despersonalização provocada pelos uniformes das detentas, as poses codificadas, além de sugerir associações entre as fotografias e as estatísticas criminais do período, em especial em relação ao perfil étnico-racial das fotografadas.

24 www.sap.sp.gov.br/common/museu/museu.php 
Já o segundo grupo de fotografias é composto por imagens reproduzidas das revistas citadas, em especial $A$ Estrela, nas quais se observa o uso de fotografias convencionais, amadoras, cuja função era ilustrar os textos sobre determinado tema. Nestas fotos modestas e circunstanciais, a pretensão artística está ausente. Não se pode buscar nelas expressão pessoal e originalidade, pois são registros anônimos cujo interesse se restringe ao testemunho documental. No entanto, é possível perceber que as fotografias não foram colocadas aleatoriamente na revista, mas são ilustrativas da representação do cárcere feminino que se queria mostrar: local limpo e em ordem, que pouco ou nada lembrava uma prisão. $\mathrm{O}$ discurso do cárcere humanizado então em voga se repete nas fotografias, que registram ambientes da Penitenciária de Mulheres de Bangu, no Distrito Federal. Estas acompanhavam pontualmente trechos do texto, podendo ser chamadas de "fotografias aplicadas". De simples registro, sem critérios estéticos de elaboração, em época de "popularização da fotografia”, considerado em certos círculos uma linguagem comum, ao alcance de todos, esse tipo de foto, na sua "banalidade e anonimato", apresenta interesse enquanto fonte visual e complementar para as indagações das ciências sociais e disciplinas afins, como é o caso do presente trabalho (LUGON, 2001, pp. 298 e 306). As fotografias selecionadas dos periódicos foram distribuídas ao longo do trabalho, materializando visualmente o que o texto descreve e analisa.

De acordo com o historiador Ulpiano Bezerra de Meneses, a Antropologia é a área das Ciências Sociais que "mais tem demonstrado sensibilidade para a dimensão social e histórica dos problemas introduzidos pela fotografia, multiplicando-se os enfoques", ou seja, os olhares sobre as imagens. Entre os aspectos que interessam à abordagem ora feita destaca-se a documentação de eventos ou situações, quadros do cotidiano, marginalização social e sua contrapartida, ou seja, imagens ideológicas de práticas no ambiente das prisões que buscam evidenciar o preparo da futura reinserção, imagens que são, enfim, "parte viva" de uma "realidade social" (BEZERRA de MENESES, 2003, pp. 11 a 36).

O terceiro grupo é formado por fotos do Presídio de Mulheres de São Paulo, disponibilizadas por Maria da Penha Risola Dias, em entrevista já mencionada, reali- 
zada em maio de 2010. São originárias do acervo das Irmãs do Bom Pastor D’Angers, da Casa de São Paulo. Foram selecionadas três fotografias posadas que ilustram personagens que transitavam pelo espaço penitenciário: as Irmãs do Bom Pastor, as presas e as funcionárias laicas. As fotos não estão datadas, o que impossibilita precisar o ano em que cada uma foi feita, sendo possíveis apenas algumas aproximações. As fotografias das Irmãs e das presas foram, segundo a entrevistada, tiradas "bem no comecinho”, possivelmente entre os anos de 1940 e 1950. Já a das funcionárias não religiosas certamente data do final da década de 1960 ou início dos anos 1970, quando elas foram contratadas. Apesar do retrato das funcionárias não fazer parte do período ora analisado, foi utilizado não só por anunciar outros tempos penitenciários, mas, principalmente, por mostrar, ao fundo, o prédio do Presidio de Mulheres de São Paulo. São fotografias nas quais é possível perceber que houve uma produção prévia, como a organização do espaço e da pose das pessoas.

Já o quarto grupo, composto por 130 fotografias da Penitenciária Talavera Bruce $^{25}$ e do Sanatório Penal, das quais foram selecionadas 40 para apreciação, foi encontrado no Centro de Estudos e Pesquisas da Escola de Gestão Penitenciária do Estado do Rio de Janeiro, que abriga um acervo sobre o sistema penitenciário do Es$\operatorname{tado}^{26}$. As fotografias, não datadas, são possivelmente da década de 1970, data aproximada à qual se chegou por meio de elementos da época presentes em algumas de$\operatorname{las}^{27}$. Apesar de escapar o limite temporal proposto nesta dissertação, o acervo foi incluído nesta análise no sentido de permitir um diálogo íntimo com o tema em pauta, ressaltando algumas permanências e descontinuidades com o momento analisado. Assim, optou-se por trabalhar as fotografias da Penitenciária Talavera Bruce e do Sanatório Penal em um epílogo que arremata o texto.

25 Nome dado ao complexo de Bangu após ter adquirido autonomia da Penitenciária Central do Distrito Federal, em 1966.

26 O acervo, já digitalizado, foi copiado no pen drive, mediante assinatura de um termo que autoriza o uso das imagens para fins acadêmicos.

27 São certamente posteriores a 1966, data em que o complexo de Bangu passou a se chamar Instituto Penal Talavera Bruce. Elementos prosaicos que aparecem nas fotografias como um refrigerante, carros, roupas e penteados (dos visitantes), permitiram concluir que são imagens da década de 1970. 


\section{ESTRUTURA DA DISSERTAÇÃO}

A década de 1940 e a primeira metade da década de 1950 representaram um período de grande ebulição do debate e da prática penitenciária no país e a criação dos estabelecimentos para encarceramento feminino fez parte desse contexto. Em outras palavras, os anos mencionados foram de grande atividade dos Conselhos Penitenciários, tanto dos estados quanto do Distrito Federal. Houve construções e reformas penitenciárias em todo o país visando a implementação de um modelo de cárcere ressocializador e voltado para a educação moral dos encarcerados; elaboraram-se grandes críticas a modelos penais ultrapassados, que imputavam sofrimento físico e moral aos presos; e foi intensa a produção legislativa no âmbito penal. Será por acaso que os primeiros presídios femininos saíram do papel nessa época, ou é possível inseri-los nesse movimento mais amplo que marca a teoria e a prática punitiva em questão? Certamente a segunda hipótese é mais plausível, dado que as instituições são socialmente construídas e fazem parte de cenários sociais muito mais amplos que elas próprias.

Assim, para compreender o momento de criação dos presídios femininos no país, fez-se necessário contextualizá-lo, traçando, ainda que brevemente, um panorama histórico do exercício prisional e da legislação criminal brasileira, efetuando o resgate da ideologia carcerária e dos projetos punitivos então em prática. Considerando que a História não é linear, mas formada por permanências e rupturas, transitar por seus momentos significa buscar entender os contextos nos quais as categorias e as instituições foram produzidas, para que então seja possível compreender, ainda que parcialmente, o que permanece e o que muda. Assim, no primeiro capítulo, fez-se uma breve recuperação dos debates prisionais, pautando-os, principalmente, nas legislações punitivas de cada período, bem como nas teorias filosóficas e criminológicas em voga no momento.

Optou-se por expor o cenário punitivo brasileiro do final do século XIX e das primeiras décadas do século XX de modo a compreender qual era o contexto criminológico e penitenciário no qual surgiu, no final da década de 1930, a primeira unidade prisional feminina brasileira. Para tanto, retoma-se alguns pontos relevantes desse cenário, desembocando no contexto punitivo e legislativo da década de 
1940, momento de investimento em reformas prisionais e da promulgação do Código Penal e do Código de Processo Penal. Igualmente analisou-se a influência de teorias criminológicas como o Iluminismo Penal, ou Escola Clássica do Direito Penal - oriunda principalmente da França e da Inglaterra do final do século XVIII - e a Antropologia Criminal, também chamada Criminologia - advinda principalmente da Itália da segunda metade do século XIX - sobre o pensamento criminológico nacional nos seus primeiros tempos, de modo a compreender em que medida essas escolas estiveram presentes na estruturação dos cárceres femininos nacionais e na delimitação das figuras das delinquentes.

Em seguida, ainda no primeiro capítulo, foram considerados alguns atores relevantes para o cenário punitivo do período, em especial aqueles que participaram da estruturação dos presídios femininos no país, os quais estão apresentados no item denominado penitenciaristas. Juristas em sua maioria, os penitenciaristas exerceram papel importante no cenário punitivo nacional do período, e o fato de serem algumas das principais vozes analisadas ao longo do texto justifica sua introdução neste primeiro momento. Por fim, tratou-se especificamente das práticas prisionais nacionais e do investimento na humanização carcerária como lema das reformas penitenciárias pretendidas a partir da década de 1930.

O segundo capítulo, intitulado "Dever ser" e "não ser" femininos, apresenta aspectos do que era esperado das mulheres em meados do século XX, e aponta quais eram as figuras desviantes desse "dever ser". Buscou-se identificar, por meio de pesquisas que denotam os papéis sociais femininos do período e a partir de autores da época, quais eram os modelos ideais de mulheres, quais os espaços sociais reservados às representantes do sexo feminino, qual o papel da mulher na sociedade e na família, para, em seguida, delimitar quais eram as figuras que representavam os desvios desses modelos. A dicotomia "mulheres honestas" versus "mulheres desviantes", que tanto aparece nas falas dos penitenciaristas, foi explorada neste capítulo de modo a verificar, adiante, até que ponto esses moldes foram usados para a classificação das figuras delinquentes e para a prática de ressocialização e recomposição moral das mulheres nos cárceres femininos brasileiros. 
Ainda no segundo capítulo, o item Agentes do desvio e o Sistema de Justiça Criminal traz dados do aprisionamento feminino na década de 1940 e 1950 que ilustram quais eram as características das mulheres sentenciadas e detidas no período analisado. Tais dados, presentes nos anuários do Serviço de Estatística Policial do Estado de São Paulo e apontados em um artigo do periódico Arquivos da Sociedade de Medicina Legal e Criminologia possibilitaram traçar o perfil daquelas a quem o sistema de justiça criminal estava voltado. Por fim, algumas fotografias de registro criminal do Presídio de Mulheres de São Paulo, seguidas de uma breve análise, fecham o capítulo.

Classificando a mulher delinquente foi o título escolhido para o terceiro capítulo, que trata da maneira como penitenciaristas e outros atores do período classificaram as mulheres criminosas. Partindo do pressuposto de que não existe o criminoso a priori, mas que tal categoria é socialmente construída, buscou-se identificar se nas falas e textos desses autores era possível delimitar "tipos criminosos femininos" e, em caso positivo, de que maneira esses tipos dialogavam com os modelos de criminalidade feminina traçados na época, em especial pelo principal teórico do tema, o já mencionado médico italiano Cesare Lombroso. Buscou-se, ainda, apontar em que medida os modelos de "dever ser" e "não ser" femininos, apresentados no segundo capítulo, pautaram tais classificações.

Finalmente, o quarto capítulo, denominado Projetos e práticas do cárcere feminino, trata das prisões femininas no Brasil - espaços destinados às figuras criminosas explicitadas no terceiro capítulo. Aborda elementos centrais que permitem compreender qual foi o projeto eleito para o aprisionamento de mulheres. Além da necessidade de separação de homens e mulheres de forma a impedir o contato entre presos de diferentes sexos e de garantir a ordem nos estabelecimentos prisionais, defendida por juristas desde o final do século XIX, outros elementos passaram a ser justificadores da separação. Dentre eles o fato de alguns países latino americanos, os Estados Unidos e países europeus terem seus presídios femininos desde meados do século XIX e de haver um investimento brasileiro para fazer parte do movimento de humanização penitenciária, que incluía a separação entre instituições femininas e masculinas. 
Nas décadas de 1940 e 1950, o cárcere tinha como funções alegadas a defesa social, ou seja, a retirada, da sociedade, de indivíduos considerados perigosos e uma função ressocializadora, capaz de recolocar os indivíduos reabilitados na sociedade. $\mathrm{O}$ trabalho era visto como elemento capaz de exercer essa função, mas era necessário assegurar que as tarefas exercidas na prisão pudessem ser reproduzidas fora dela, permitindo a ressocialização. Nesse sentido, às mulheres deveriam ser garantidos meios de reprodução de uma vida ideal feminina, em consonância com um modelo de "dever ser" mulher. Além disso, os penitenciaristas se perguntavam de que maneira deveria ser estruturado esse espaço de modo a garantir um tratamento próprio para mulheres, sem, contudo, tratá-las com privilégios e regalias não disponibilizados para os homens presos.

Outra questão relevante marcou a origem dos cárceres femininos no país: a quem caberia o cuidado cotidiano com as detentas? A escolha pela Congregação Nossa Senhora da Caridade do Bom Pastor d'Angers revela elementos importantes da forma como a delinquência feminina era vista no período, levanta questóes sobre a laicidade estatal, bem como sobre a prática prisional. Assim, o quarto capítulo aborda esses elementos, ressaltando brevemente o histórico e a "vocação" da Congregação de Nossa Senhora da Caridade do bom Pastor d'Angers, alguns elementos sobre sua presença nos cárceres femininos chilenos, argentinos e, logicamente, brasileiros, bem como dados referentes ao cotidiano prisional estabelecido pelas Irmãs e à relação entre o Estado brasileiro e a Igreja Católica. Ainda nesse capítulo, trata-se da arquitetura dos cárceres e do trabalho prisional nos estabelecimentos femininos. Fotografias retiradas dos periódicos e de personagens do Presídio de Mulheres de São Paulo compõem, igualmente, este capítulo. Por fim, nas considerações finais, no item Corpos e almas das detentas à luz de alguns teóricos clássicos, recorre-se a conceitos e análises feitas por Marcel Mauss, Erving Goffman e Michel Foucault para examinar, em diálogo com esses autores, elementos relevantes dos cárceres para mulheres. Um epílogo composto por uma narrativa de imagens e texto fecha esta dissertação. 


\section{Capitulo Um}

\section{BREVE HISTÓRICO \\ DOS DEBATES PRISIONAIS \\ E DA LEGISLAÇÃO \\ PENAL NO BRASIL}

\section{LEGISLAÇÃO PENAL}

A Constituição Imperial de 1824 e o Código Criminal de 1830 foram os primeiros instrumentos a refletir, no plano legal, o debate que vinha ocorrendo nos meios jurídicos e políticos sobre o encarceramento no país. Em seu artigo 179, incisos XIX, XX e XXI, a Constituição de 1824 ressaltava, respectivamente, que: "desde já ficam abolidos os açoites, a tortura, a marca de ferro quente, e todas as mais penas cruéis"; "nenhuma pena passará da pessoa do delinqüente (...)"; e "as Cadêas serão seguras, limpas, bem arejadas, havendo diversas casas para separação dos Réos, conforme suas circunstâncias, e natureza dos seus crimes”. Já o Código Criminal de 1830, apesar de manter as penas de galés, a pena capital e castigos corporais, inovou ao introduzir, em seu artigo 46, a pena de prisão com trabalho diário, em prática nos países cujas técnicas penitenciárias eram consideradas de vanguarda.

Essa mudança na legislação era fruto da tentativa de incorporar ao Direito brasileiro preceitos liberais de cunho iluminista em voga em alguns países europeus e nos Estados Unidos, sem, no entanto, colocar em risco o poder monárquico. 
A Constituição de 1824, ao mesmo tempo em que excluía os escravos de seu texto, inovava por estruturar os poderes, conferir competências e assegurar direitos individuais. Ao mesmo tempo em que detinha cláusulas liberais, centrava-se na figura do imperador, que possuía poderes para além de qualquer instância (FAUSTO, 2000, p.149). Ao analisar os anos finais do reinado de Dom Pedro I no Brasil, Sérgio Buarque de Holanda afirma que “(...) o seu liberalismo era teórico e, sobretudo, imaginativo, feito de distâncias como um binóculo, próprio para ver de longe. E o Brasil estava cada vez mais perto, apresentava-lhe um desafio cada vez mais permanente. $\mathrm{O}$ Brasil onde a revolução prosseguia o seu curso” (HOLANDA, 1985, p. 396).

Já o Código de 1830 fora inspirado nas mesmas bases ideológicas da Constituição de 1824, ou seja, o Iluminismo Penal do século XVIII. Os legisladores e juristas brasileiros foram influenciados em grande parte pela Escola Clássica do Direito Penal, cujos principais representantes são Cesare Beccaria e Jeremy Bentham ${ }^{28}$. A pena, para Beccaria, justificava-se antes na utilidade de prevenção, que em argumentos retributivos ou de vingança. Em outras palavras, esta deveria ser eficaz para prevenir e combater o delito, sendo os castigos cruéis contraproducentes, devendo a lei penal servir para proteger a sociedade do arbítrio estatal e para dar uma resposta punitiva aos que delinquiram.

Os juristas e legisladores brasileiros foram, aos poucos, argumentando em prol de uma prática punitiva que levasse em consideração a recuperação moral do indivíduo que cometeu um ato delituoso. Nesse contexto, o ato criminoso era fruto da escolha individual, e deveria ser punido de forma a expiar a culpa do condenado.

28 Cesare Bonesana, conhecido como Marques de Beccaria (1738 a 1794), autor de Dos Delitos e das Penas, é considerado um expoente do Iluminismo Penal. Seu trabalho é pautado em algumas teorias contratualistas, que são refletidas em seu texto, principalmente quando remete à origem das penas ao contrato social. (ANITUA, 2007, pp. 160 a 164). Em relação ao autor, Sant'Anna ressalta que “(...) as mudanças na forma de punir se inseriam em um conjunto de ideias liberais europeias, pertencentes ao campo da escola Clássica do Direito Penal, que tinha em Cesare Beccaria (...) um precursor"(SANT'ANNA, 2009, p.291). Já Jeremy Bentham (1748 - 1832) é considerado o criador do pensamento utilitarista, bem como de reflexões sobre a importância da disciplina para o controle social. Foi responsável pela criação do projeto do panóptico, que consiste em uma estrutura arquitetural carcerária capaz de promover vigilância constante. Nesse modelo arquitetônico, o princípio da masmorra é invertido, ou seja, não mais o condenado é trancado, privado de luz e escondido, mas sim, ainda que igualmente trancado, passa a ser exposto à luz e observado. Todos são observados, todos observam e, principalmente, todos se sentem, a todo instante, vigiados (ANITUA, 2007, pp. 208 e 209). 
A prática do crime poderia ter sido circunstancial e era possível, por meio do castigo corretamente aplicado, persuadir o indivíduo a não mais delinquir, bem como mostrar para a sociedade que para todo crime cometido haveria uma resposta do Estado.

A pena com trabalho, em prisões remodeladas, representava a modernidade punitiva em meados do século XIX. Estar na vanguarda era investir em novos cárceres e, principalmente, em outra ideologia punitiva, capaz de superar os açoites, as penas de morte, os castigos físicos e as masmorras. Nesse sentido, o criminólogo Gabriel Ignácio Anitua realça a aversão de Beccaria às penas com castigo, ao afirmar que o autor "manifestava sua repulsa em relação à pena de morte e aos castigos corporais, evidenciando-a na capa da edição alemã de seu livro, na qual aparece a deusa da justiça evitando olhar para várias cabeças cortadas e mirando, satisfeita, diversos instrumentos de trabalho" (ANITUA, 2007, p.163).

Aos poucos, a progressiva mudança legal se tornava uma necessidade prática. A Lei, naquele momento, tinha como uma de suas funções criar instituições nacionais, servindo como guia para a construção de uma nação civilizada. Apesar de muitos dos textos legais serem letra morta, sendo sua aplicação relativa, alguns deles de fato saíram do papel. Foi o caso da criação de estabelecimentos correcionais inaugurados para abrigar condenados a penas de prisão com trabalho, em conformidade com o Código Criminal de 1830.

A província de São Paulo e a Corte do Rio de Janeiro ${ }^{29}$ destacavam-se no cenário punitivo nacional, à medida que buscaram colocar em funcionamento estabelecimentos que investiam na correção, principalmente por meio do trabalho. Além das cadeias públicas então existentes, São Paulo e Rio de Janeiro construíram Casas de Correção como espaços-modelo para o encarceramento no período imperial, em consonância com as exigências do Código Penal de 1830, que previa a pena de prisão com trabalho. De acordo com o sociólogo Fernando Salla, "o aparecimento da

29 Outros estados, como a Bahia, o Rio Grande do Sul e Pernambuco, construíram suas casas ou escolas correcionais no final do século XIX e início do século XX. Optou-se por falar das casas de São Paulo e Rio de Janeiro por terem sido os primeiros locais do país a se adequarem ao código de 1830, investindo na pena de prisão com trabalho. 
Casa de Correção de São Paulo, em 1852, bem como a do Rio de Janeiro, em 1850, significou a materialização de uma nova percepção das formas de atribuição e execução das penas que vinha se dando desde o processo de independência" (SALLA, 1999, p.65).

O fato de o Brasil ser um país escravista, no entanto, refletia os paradoxos entre o humanismo iluminista que se buscava praticar e a estrutura social vigente. Como conciliar os princípios de regeneração do apenado para o convivo social quando considerados os presos escravos, e, de que forma equacionar a regeneração pelo trabalho em uma sociedade que o degradava são questões pontuadas por Koerner, ao analisar a legislação do período. Nesse sentido, o autor sublinha diferenças no tratamento recebido por escravos e criminosos comuns nas casas de correção. Segundo Andrei Koerner “(...) as prisões da sociedade escravista não visavam regenerar pelo menos uma parcela dos detidos: os escravos criminosos. Os excessos na punição, sua publicidade e o seu caráter ritual davam à punição dos escravos um caráter de vingança exemplar e de intimidação" (KOERNER, 2001, p. 212).

Em 1890, o Código Criminal Imperial foi reformado para se adaptar ao novo cenário político brasileiro. A República recém proclamada necessitava de uma mudança legislativa que marcasse o novo momento histórico, e o fim da escravidão era por si só um motivo relevante para que fosse revista a legislação criminal de 1830. Dentre outros, o Código de 1890, além de eliminar todos os artigos referentes à escravidão, aboliu as penas de galés e o caráter perpétuo das penas, que deveriam limitar-se a trinta anos de cumprimento máximo por condenação; consagrou a privação de liberdade como forma de punição privilegiada no país; instituiu a retroatividade da lei penal diante de uma lei mais benéfica para o condenado; fixou o modelo penitenciário Irlandê $s^{30}$ como padrão para as penitenciárias brasileiras e previu a progressão de regime para os apenados. Esse instrumento legal, no entanto, não rompeu com a ideologia predominante no código anterior, mas manteve seu embasamento no Direito Penal clássico. De acordo com Salla, o Código Penal de 1890

$30 \quad$ Esse modelo será explicado adiante. 
pode ser considerado decorrência de um "amadurecimento" de críticas que vinham sendo feitas ao código de 1830 e, em momentos posteriores, principalmente na década de 1870, às penas e sua aplicação (SALLA, 1999, p. 145).

No entanto, uma vez promulgado, críticas a esse novo instrumento legal não tardaram a aparecer. Além de reproduzir em grande medida os ditames filosóficos do Código de 1830, a principal desaprovação era de que este não incorporava diretrizes da Escola Penal Positiva, pensamento que já havia um tempo circulava nos meios intelectuais e políticos do país.

Produto de seu tempo, apesar, é claro, das influências advindas de pensamentos anteriores e contemporâneos - como o Positivismo de Auguste Comte, o degeneracionismo francês, os estudos biológicos de Charles Darwin ${ }^{31}$, dentre outros -, a Escola Positiva de Direito Penal, Antropologia Criminal, Criminologia ou Positivismo Criminológico ${ }^{32}$ deve ser analisada quando em pauta o pensamento intelectual brasileiro do final do século XIX e início do século XX. Nascida na recém unificada Itália, na década de 1870, tal escola é considerada a primeira a formular modelos científicos para a compreensão do crime e do criminoso. Negando a metafísica e as formulações teológicas, o Positivismo Criminológico reivindicava para si o status de ciência, uma vez que, colocando em prática o método de observação e experimentação sensível dos fenômenos, pretendia formular leis gerais que explicassem o comportamento criminoso de homens e mulheres.

O crime, fruto da atividade humana, deveria ser analisado enquanto tal. Em outras palavras, as explicações metafísicas não bastavam. Era preciso utilizar um método de análise capaz de dar respostas objetivas e comprováveis que rompesse com as especulações e investisse em uma "ciência" verdadeira ${ }^{33}$. A etiologia do crime não poderia deixar de passar pela análise do criminoso, já que este era o agente e a resposta para a sua ação desviante poderia estar nele mesmo. Se o crime era um produto da

31 Para uma análise mais detalhada dessas influências, ver FERLA, 2009, pp. 25 a 31; e SHECAIRA, 2008, pp. 84 a 97.

32 Ferla pontua ainda outros nomes atribuídos à Escola Positiva de Direito Penal. São eles: Escola Italiana, Escola Moderna e Escola Científica (2009, p. 23).

33 Nesse sentido ver CARRARA, 1998, pp. 62 a 68. 
atividade humana, logo a pergunta deveria ser: quem é o criminoso? Segundo a antropóloga Lilia Schwarcz, "contrária à teoria do livre arbítrio, a escola criminal positiva acreditava que o universo regido por leis mecânicas, causais e evolutivas, não dava margem às liberdades do indivíduo" (SCHWARCZ, 2008, p. 166).

Três são os autores principais que devem ser considerados quando em pauta a origem da escola positivista criminológica: Cesare Lombroso, Enrico Ferri e Rafaelle Garófalo. Influenciados pela escola degeneracionista francesa, representada por August Morel, segundo o qual a hereditariedade e os caracteres físicos e constitucionais estavam intimamente ligados aos transtornos mentais, esses autores propuseram elevar os estudos sobre a delinquência a um patamar "científico" (FERLA, 2009, pp. 25 e 26). Suas principais obras foram traduzidas para diversas línguas e distribuídas para além do continente europeu. Anitua pontua que "Lombroso, antes de constituir uma criação original, é o resumo genial e a conclusão das idéias frenológicas e psicofísicas de seu século, as quais recobre com o título de uma nova 'ciência', cuja ajuda era solicitada pelo penalismo do final do século." (ANITUA, 2007, p. 298). Muitos atribuem a fama de Lombroso ao caráter simplista de seus argumentos, o que facilitava a compreensão de suas teses por um público não especializado, popularizando-as (ALVAREZ, 2003, p. 46; ANITUA, 2007, p. 306). Em especial na América Latina, onde nações buscavam se modernizar e perder o estigma de "quintal dos países civilizados", a "nova ciência" de Lombroso e seus discípulos representou, no final do século XIX e início do XX, a modernidade científica capaz de transformar e erguer instituições nacionais.

Além de tratarem das características físicas dos homens delinquentes, autores da Antropologia Criminal se preocuparam também em traçar o perfil das mulheres delinquentes. Uma das primeiras obras a tratar especificamente da criminalidade feminina foi o estudo de Lombroso e Ferrero intitulado La Donna Delinquente, la Prostituta e la Donna Normale, de 1893. Os autores buscaram com esse estudo mostrar que as mulheres criminosas aparecem em menor proporção uma vez que seriam menos evoluídas biologicamente que os homens, sendo mais sedentárias e menos ati- 
vas, o que as levaria a menor capacidade de evolução da degenerescência ${ }^{34}$.

O ideário positivo-evolucionista que circulava nos meios intelectuais europeus e nos Estados Unidos desde meados do século XIX aportou em terras brasileiras na década de 1870, período importante na história do Brasil, já que o país se tornara havia quase meio século uma nação independente, e buscava edificar-se enquanto tal. $\mathrm{O}$ método experimental de investigação científica proposto pelos positivistas enunciava a "verdadeira ciência", livre dos dogmas religiosos e das variações metafísicas, encantando os estudiosos das ciências naturais e biológicas, aqueles que transitavam pelas humanidades, bem como políticos e militares. Os lemas positivistas de ordem e progresso passaram a estampar a bandeira do Brasil republicano, simbolizando a importância dada à filosofia positivista no país (SCHWARCZ, 2008, pp. 11 a 22).

Pensar o país para transformá-lo em uma nação exemplar significava refletir sobre temas latentes que precisavam ser resolvidos com urgência. Dentre eles, a questão racial brasileira incomodava sobremaneira os intelectuais nacionais, já que o país era retratado como sendo mestiço, mulato, e esse retrato, para muitos, poderia representar atraso, já que eram das nações de brancos que chegavam os exemplos de progresso, civilização e modernidade. Intelectuais estrangeiros também formulavam suas opiniões acerca do Brasil mestiço, em geral vinculando a miscigenação ao atraso e à pobreza. Nesse cenário, a entrada das teorias raciais no país, ainda que de maneira tardia - já que na Europa eram teorias em voga no início do século XIX -, representou um momento de reflexão sobre a nação e de incentivo à produção científica (SCHWARCZ, 2008, pp. 11 a 22).

Data igualmente da década de 1870 a reorganização e o investimento em instituições de ensino, pesquisa e produção científica no país ${ }^{35}$. Faculdades de Direito, de Medicina, Museus Etnográficos, Institutos Geográficos e suas respectivas

34 A obra La Donna Delinquente, la Prostituta e la Donna Normale será analisada detalhadamente no terceiro capítulo deste trabalho.

35 Reorganização, uma vez que as instituições de ensino como as faculdades de Direito do Recife e de São Paulo foram inauguradas na década de 1820. Já um decreto de 1832 autorizara a transformação das academias médico-cirúrgicas em faculdades ou escolas de medicina. Por sua vez, os Museus Etnográficos, Museu Paraense Emílio Goeldi, Museu Paulista e Museu Nacional, com a exceção do último, inaugurado em 1808, foram criados na segunda metade do século XIX (SCHWARCZ, 2008, pp. 70 e 196). 
Revistas compunham um conjunto de instituições científicas de onde emanavam saberes especializados, formando especialistas e homens de ciência que fariam parte dos quadros intelectuais da nação, e ajudariam a refletir sobre os principais temas em pauta no momento. Schwarcz, ao analisar a relevância e a utilização das teorias raciais no país entre 1870 e 1930, ressalta o momento peculiar vivido no Brasil, no qual teorias contraditórias como o liberalismo e as teorias raciais baseadas no ideário positivista-evolucionista conviviam de maneira original. Em suas palavras,

paradoxo interessante, liberalismo e racismo corporificavam, nesse momento, dois grandes modelos teóricos explicativos de sucesso local equivalente e no entanto contraditório: o primeiro fundava-se no indivíduo e em sua responsabilidade pessoal; o segundo reiterava a atenção colocada no sujeito para centrá-la na atuação do grupo entendido enquanto resultado de uma estrutura biológica singular (SCHWARCZ, 2008, p.14).

O conflito existente entre Liberalismo e Positivismo na formação dos saberes jurídicos e médicos, bem como a convivência dessas correntes de pensamento no plano legal e político, marcou o Brasil no final do século XIX. No entanto, apesar de algumas instituições serem mais liberais e outras mais positivistas (como era o caso, respectivamente, das faculdades de Direito de São Paulo e de Recife), ou mesmo de algumas profissões assumirem posturas mais positivistas que outras na disputa por privilégios de saber (a Medicina acusava o Direito de ser liberal), pode-se afirmar que houve no Brasil uma combinação dessas duas linhas de pensamento, sendo ao pensamento liberal incorporados preceitos positivistas e evolucionistas. Segundo a autora: "o mesmo contexto que encontra em um projeto liberal a solução para sua nova configuração política procura nas teorias deterministas e antropológicas subsídio para transformar diferenças sociais em barreiras biológicas fundamentais" (SCHWARCZ, 2008, p. 241). Essa equação entre política liberal e determinismo social poderia ser verificada tanto em relação às ques- 
tões raciais quanto àquelas envolvendo a delinquência ${ }^{36}$.

Em relação ao crime, ao mesmo tempo em que o Código Penal de 1890 trazia em seu bojo preceitos liberais, recebia críticas de que mais vanguardista em termos de tratamento penitenciário era o positivismo criminológico, ausente na lei. De acordo com Marcos César Alvarez,

desde a sua promulgação, e praticamente ao longo de toda a Primeira República, o Código de 1890 recebera inúmeras críticas, como se já nascesse ultrapassado, diante das mais avançadas teorias jurídicas da época e das novas urgências históricas locais. (...) É certo, no entanto, que o Código de 1830 aparece como defeituoso para muitos de seus contemporâneos porque estes já se baseiam em novas teorias jurídico-penais que começavam a penetrar no Brasil no início do século (ALVAREZ, 2003, p.18).

Segundo René Ariel Dotti, a discussão tanto no plano doutrinário, quanto no acadêmico, em relação aos postulados e ao confronto da Escola Clássica e Positiva instigava os movimentos de reforma precoce do diploma (DOTTI, 1995, p.225). Nesse sentido, Alvarez pontua que muitos juristas estavam insatisfeitos com a presença de dispositivos penais clássicos no Código Penal de 1890. Em suas palavras,

essa insatisfação revela a tensão, que perpassa toda a primeira república, entre a necessidade de constituir uma nação organizada nos moldes jurídicos-políticos contratuais, que colocasse o país na linha do progresso trilhado pelas demais nações civilizadas, e as particularidades históricas, raciais e sociais do contexto nacional que dificultavam, aos olhos das elites republicanas, essa constituição. O desafio era o de institucionalizar os ideais de igualdade, em termos jurídico-penais em face das desigualdades percebidas como constitutivas da sociedade (ALVAREZ, 2003, p. 71).

Apesar de não ter havido uma reforma formal, várias foram as novas leis que

36 Ver também CARRARA, 1998, pp. 61 a 126; e CUNHA, 1988. 
se somaram ao coro das leis criminais, havendo inclusive em 1932 a consolidação dessas leis em um instrumento único, de modo a garantir sua aplicação e mesmo sua divulgação. No entanto, um novo Código Penal seria promulgado na década de 1940, revogando o Código de 1890 e outras legislações penais que o acompanhavam. Se o Código de 1890 nasceu sob muitas críticas e pouco foi cumprido, principalmente no tangente às suas previsões sobre prática carcerária, o de 1940 tinha a pretensão de ser mais passível de cumprimento, buscando concatenar-se com a realidade.

\section{CENÁRIOS LEGISLATIVO E PUNITIVO NAS DÉCADAS DE 1930 E 1940}

não se póde tentar uma reforma penitenciária séria, definitiva, integral, sem começar-se pela base: a reforma do Código (Lemos Britto, 1924).

A criação do Código Penal de 1940, que entrou em vigor em 1942, representa um importante momento para o Direito Penal nacional. Fruto de um projeto original de Alcântara Machado, modificado em grande parte pela comissão revisora, formada, dentre outros, pelos penalistas Nelson Hungria e Roberto Lyra, o Código, segundo Nilo Batista e Eugênio Raul Zaffaroni, é produto de um tempo de intensa produção legislativa, já que, desde 1930, no início do governo Vargas, uma reforma política e administrativa estava sendo realizada. A necessidade de centralização política e administrativa do período exigia uma reconfiguração do plano legal nacional. Desde a década de 1930 o aparato legislativo estava em constante modificação (BATISTA e ZAFFARONI, 2003).

No início dos anos 1930, com a chegada de Getúlio Vargas à presidência do país, houve um empenho em reformar, elaborar e organizar a legislação existente, em sua maioria oriunda do início da República, pouco adaptada aos "novos tempos". De acordo com Rafael Queiroz: 
o Brasil pós 1930 assistiu à elaboração de muitos outros códigos [além do Penal e de Processo Penal], tanto na tentativa de organizar a legislação esparsa existente sobre determinadas matérias (como nos casos do direito processual civil, do direito do trabalho e, em um primeiro momento do direito penal), quanto no propósito de reformular a antiga legislação já existente sobre determinadas matérias, como o direito dos negócios, o direito eleitoral (1932) e o direito dos transportes (QUEIROZ, 2007, p. 118).

No ano de 1934, foi promulgada a Carta Magna que marcaria - apenas em tese - o fim do processo revolucionário iniciado em 1930, que fora profundamente questionado pela revolução constitucionalista de 1932 e finalmente pactuado entre Vargas e os paulistas com a convocação da Constituinte que elaboraria a nova Constituição do país. Com conteúdo ampliado, se consideradas as anteriores, a Carta inaugura na legislação brasileira o voto feminino e aumenta consideravelmente os poderes da União e do Executivo. Mesmo sendo resultado de uma conjunção de forças políticas, a primeira carta promulgada no período Vargas já traz consigo, explícita e implicitamente, a imagem do regime forte e do Estado centralizador. Já a Constituição de 1937 foi introduzida no início do período ditatorial do Estado Novo. Um Executivo fortalecido é uma das características principais deste texto. Por se tratar de um período ditatorial, muito do seu conteúdo não foi considerado por Getulio Vargas, o que colaborou para a ineficácia de grande parte da lei em questão.

A modernização do país passava pela modernização legislativa. Isso pode ser percebido pelo aumento da produção legislativa desde meados dos anos 30. Segundo Queiroz:

nesse ambiente intelectual de alinhamento com o 'novo' também se inseria o direito: visto por parte da elite da sua época como verdadeiro instrumento de engenharia social, o ordenamento jurídico e a ciência do direito tinham papel importante na implementação do 'novo', ou seja, na modernização que a elite de então vislumbrava para o Brasil daquela época. Por esse motivo o direito jogou importante papel nesse processo modernizador. Ele foi a um só tempo instrumento de modernização e objeto de ação modernizante: ou 
seja, percebia-se que o direito poderia mudar a sociedade, desde que ele mesmo mudasse com ela (QUEIROZ, 2007, p. 133).

É nesse cenário, portanto, que surgem os Códigos Penal e de Processo Penal de 1940 e 1941, respectivamente. Antes de dar início à análise do Código Penal, no entanto, é importante ter em mente que o fato das primeiras instituições prisionais femininas terem sido criadas na mesma década de sua promulgação não pode ser considerado mera coincidência, mas sim fruto de um momento histórico semelhante de criação, reforma e modernização de instituições e leis, que vinha ganhando corpo desde meados do século XX. Assim, a importância de situar aqui os pensamentos e debates presentes na elaboração e no texto final do Código Penal de 1940 reside, principalmente, na delimitação de um tempo histórico que coincide com o do objeto desta pesquisa.

Rafael Queiroz mostra que o embate entre o cientificismo positivista e a metafísica do Direito Penal Clássico era o principal ponto a ser considerado no projeto do Código de 1940. Como já mencionado, a legislação penal de 1890 foi considerada ultrapassada desde sua promulgação, por não estar em consonância com a modernidade científica preconizada pelo positivismo criminológico, logo a nova legislação deveria trazer em seu bojo a aplicabilidade dos preceitos dessa Escola. Esse embate entre as Escolas pode ser percebido tanto no projeto original de Alcântara Machado quanto no resultado final produzido pela comissão revisora.

Um exemplo do embate teórico presente no Código de 1940 é a estruturação do "sistema duplo binário", ou seja, a previsão de dois tipos de reações penais voltadas para os imputáveis. Em outras palavras, havia, além da pena de reclusão calculada com base na culpabilidade e na gravidade do ato, a aplicação de medida de segurança com base na periculosidade do autor, com o objetivo de promover a defesa social retirando o indivíduo do seio social, bem como de colocar em prática um tratamento curativo. Tal binarismo das reações penais pressupunha, segundo os antropólogos Peter Fry e Sergio Carrara, duas classes de indivíduos: 
na primeira delas, estavam aqueles que violavam voluntariamente o contrato social, considerado como base do direito; e, responsáveis por essa violação, deveriam restituir o equilíbrio social rompido ao se submeterem à punição prevista. (...) $\mathrm{Na}$ segunda classe, estavam colocados os indivíduos que compartilhavam de uma espécie de essência criminosa e que, por isso mesmo, romperiam contínua e quase que involuntariamente esse equilíbrio social (CARRARA e FRY, 1986, p. 49)

De acordo com esses autores, a existência dessas duas classes de indivíduos era irrelevante perante um quadro mais amplo da existência de duas concepções ideológicas sobre o indivíduo, ou seja, aquela baseada no paradigma Clássico e no paradigma Positivista. A convivência desses dois paradigmas ao longo da segunda metade do século XIX e da primeira do século XX acabou por ser representada na legislação penal promulgada no período. De um lado, havia aqueles influenciados pelos clássicos, que viam o delito como fruto de escolhas pessoais, colocando o livre arbítrio em primeiro plano. De outro, aqueles que, influenciados por Lombroso e seus discípulos, viam no delinquente um indivíduo enfermo, que deveria ser recolhido da sociedade e tratado em instituições especializadas. A medida de segurança responderia a um anseio positivista de encarcerar para tratar e isolar o indivíduo, ao passo que a pena seria uma maneira de expiar a culpa, conforme a lógica clássica. De acordo com Fry e Carrara:

ao nível do direito penal, o Código de 1940 parece ter representado a tentativa de conciliação desses dois paradigmas políticos e intelectuais divergentes. Naquele momento, porém, as forças pareciam estar em equilíbrio, resultando numa solução híbrida a que se chega em 1940 de impossível realização prática (CARRARA \& FRY, 1986, p.50).

Outro ponto inovador na legislação em pauta, que rompia com o modelo clássico e introduzia uma perspectiva positivista, era a consideração dos antecedentes criminais e da personalidade do agente no momento de individualização da pena. Queiroz, ao analisar a Exposição de Motivos do Código Penal de 1940, salienta a im- 
portância dada à personalidade e aos antecedentes na fixação da pena cominada ao réu. Em suas palavras, "para melhor cumprir com o seu desiderato de defesa social, o Código de 1940 também se afastou dos rígidos limites impostos pelo dogma clássico da proporcionalidade em abstrato entre crime e pena, conferindo ao magistrado larga margem de atuação no momento de aplicação da pena” (QUEIROZ, 2007, p. 220).

Para Batista e Zaffaroni, não é possível afirmar que o Código Penal de 1940 era uma legislação baseada no positivismo criminológico, mas, como bem ressaltaram Carrara e Fry, se tratava de legislação com traços de diferentes linhas teóricas. A citação de frase dita pelo penalista brasileiro Magalhães Noronha, segundo o qual o novo código "acendeu uma vela para Carrara [penalista clássico] e outra para Ferri [antropólogo criminal]", é oportuna para mostrar a ambiguidade teórica expressa na Lei (MAGALHÃES NORONHA apud BATISTA e ZAFFARONI, 2003, p. 464).

A disputa entre as distintas linhas teóricas que sustentam tal binarismo punitivo, explicitada por autores contemporâneos, pode ser verificada ao longo das páginas dos Arquivos Penitenciários do Brasil. O jurista Mario Lessa, em 1940, justificava a importância da individualização da pena, prevista pela legislação, com base nas patologias apresentadas pelo delinquente. $\mathrm{O}$ tratamento diferenciado para cada pessoa deveria ser colocado em prática na instituição prisional por especialistas treinados. A seu ver:

não basta julgar o indivíduo criminoso e condená-lo a uma pena de privação de liberdade por determinado tempo; É mister verificar qual espécie de criminoso é esse indivíduo, qual é o seu estado físico, o seu estado moral, as suas tendências, o seu caráter, os seus sentimentos, a fim de aplicar-lhe o regime penitenciário adequado a torná-lo um homem útil a si e à coletividade. O criminoso, especialmente o habitual ou profissional, deve, em regra, considerar-se como se fosse um doente físico. Diversas causas o determinaram e impeliram na trilha do crime: a idade, o temperamento, a instrução, a educação, o meio em que vivia, as condiçôes econômicas e psicológicas, deficiências, intelectuais ou psíquicas. Tudo isso tem que ser observado e remediado pelo regime penitenciário para que logre êxito a pena de prisão imposta ao delinqüente (APB,1941a, p.266) 
Todavia em entrevista concedida por Roberto Lyra, publicada nos Arquivos Penitenciários do Brasil de 1941, na seção Impressões de criminalistas e sociólogos sobre o novo código penal, ele sublinhava a pureza doutrinária do Código, pontuando a importância da individualização da pena para a obtenção de um melhor resultado. Há em sua declaração antes uma tentativa de mostrar que a nova legislação trazia o que havia de mais adequado à realidade nacional, que de mostrar que se haviam seguido os preceitos de uma ou outra Escola. Lyra, que fora membro da comissão revisora do projeto original de Alcântara Machado, se mostrava encantado não só com a individualização da pena, mas também com o produto final - a seu ver uma lei imparcial, em consonância com seu tempo e com uma técnica jurídica de alta qualidade. É possível verificar tal fascínio em sua afirmação de que:

o novo código não se filiou a qualquer escola e só levou em conta as realidades e as necessidades atuais do Brasil. É, portanto, um momento estruturado sob a inspiração do meio e da época, encerrando, porém, pela elasticidade de suas fórmulas e pela consistência de sua substância, os elementos duradouros de toda a codificação. É um código cientificamente unitário, politicamente defensista e tecnicamente pragmático, tanto vale dizer, orientado pelas opções da conveniência dentro da oportunidade, no tumulto das polêmicas doutrinárias. A sua filosofia é a da utilidade, segundo as peculiaridades brasileiras e as exigências de nossa cultura. Sem prescindir do método como conjunto de operações lógicas, serviu aos fins práticos da técnica, com simplicidade, clareza, precisão e harmonia. O juiz não mais julgará, o promotor público não mais acusará, o advogado não mais defenderá um réu de episódio limitada e artificialmente esclarecido, mas, apreciará, profunda e amplamente, um homem, uma vida, um destino... A indeterminação das sanções permitirá a correspondência entre o perigo ou o dano e a defesa social. Será uma realidade o ideal de van Hamel: depois de exortar os homens a conhecer a justiça, exortemos a justiça a conhecer os homens... (APB, 1941b, p.92)

Nas páginas dos Arquivos Penitenciários do Brasil e da revista A Estrela a combinação de teorias é constante, sendo possível afirmar que talvez esse seja o re- 
trato mais fidedigno do pensamento criminológico brasileiro na década de 1940: bricolagens teóricas que uniam o clássico ao moderno, o passado e o presente, com uma criatividade peculiar. No entanto, independentemente dos embates teóricos, havia uma preocupação cada vez maior com a humanização da pena e com a (re) constituição moral dos aprisionados em um cárcere salubre, disciplinado e organizado, o que, para além dos ensinamentos das escolas, representava um verdadeiro lema dos penitenciaristas do período.

Em relação especificamente ao encarceramento feminino, o Código Penal de 1940 , no parágrafo $2^{\circ}$ do artigo 29 , previa, pela primeira vez, o cumprimento de pena em estabelecimento específico para abrigar mulheres ou, quando não fosse possível, em espaço reservado nos estabelecimentos prisionais comuns aos dois sexos. Tal previsão acelerou, em alguns estados, como São Paulo, Rio de Janeiro e Pernambuco providências como a edificação de prisões só para mulheres e/ou a reorganização de espaços prisionais coletivos, de modo a cumprir a legislação ${ }^{37}$.

\section{PENITENCIARISTAS}

Muitos eram os administradores de estabelecimentos prisionais que participavam ativamente dos debates acerca da situação prisional no século XIX e na primeira metade do XX. Isso se dava, além de outras razões, "pela capacidade que demonstraram de argumentar a favor ou contra as diferentes formas de organização e funcionamento da prisão revelando a constante atualização com as linhas do debate formulado no exterior" (SALLA, 1999, p.110). Teoria e prática conviviam nos discursos, nos artigos, laudos e pareceres, bem como no cotidiano prisional. Salla aponta que eram frequentes as viagens de profissionais envolvidos direta ou indiretamente com as prisões para a Europa e Estados Unidos, com o objetivo de se inteirarem das novidades prisionais em prática naqueles espaços (SALLA, 1999, p.126). Além dos debates sobre as motivações do crime, o problema da delinquência e a importân-

$37 \quad$ Este tema será tratado detalhadamente no quarto capítulo. 
cia da punição, a estruturação das prisões e dos estabelecimentos para cumprimento de penas estava igualmente em pauta. Qual seria o melhor modelo punitivo e quais eram as maneiras ideais de organizar o cárcere eram questões sempre presentes.

O papel dos penitenciaristas, ou penalogistas, desde meados do século XX, era fundamental para a reflexão acerca do encarceramento no país e o implemento de reformas capazes de aliar ciência e prática carcerária. Na maioria juristas e médicos, os penitenciaristas eram homens empenhados em pensar o cárcere, seu papel e funções na sociedade e as soluções para o seu melhor funcionamento. A modernização da instituição prisional deveria, necessariamente, passar pelas reflexões, sugestões e projetos desses homens especializados na "ciência penitenciária".

Personalistas e com posicionamentos pragmáticos, como se poderá notar, esses penitenciaristas mantinham relações próximas com autoridades governamentais e políticos. Estavam sempre presentes nos congressos internacionais, nas academias, na mídia, nos meios políticos e, alguns, no cotidiano prisional. Eram considerados autoridades no assunto sendo acionados constantemente por governos dos estados ou pelos conselhos penitenciários locais para dar pareceres sobre a situação prisional e apresentar propostas de reformas. Representavam uma "elite penitenciária”, detentores de um saber específico e com as chaves para a modernização das instituições em suas mãos. Como o próprio Lemos Britto ressalta, no plano de reorganização do Sistema Penitenciário do estado da Bahia, havia no país disponível para a consulta “(...) uma elite de criminólogos e psiquiatras, de sociólogos e de pedagogos, para os quais podem os governantes apelar com segurança, em pretendendo reformar suas prisões e seus respectivos regulamentos" (APB, 1942a, p. 79).

Os penitetenciaristas eram reconhecidos por suas análises e propostas de melhorias para o sistema carcerário. Em um período no qual muito se discutia a importância da humanização do sistema penitenciário e da pena, de modo a permitir a reintegração do delinqüente no seio social, a voz dos penitenciaristas era tida como o eco de uma ciência humanizada e evoluída, que deveria ser escutada para a garantia da modernização das instituições prisionais. Em um dos primeiros volumes de A Estrela há um exemplo da função de proponentes e implementadores de soluções 
humanizadas para as questóes penitenciárias esperada dos penitenciaristas. Ao tratar da importância da individualização da pena para o sucesso do aprisionamento, o artigo assinado por Plauto de Azevedo pontua:

os penitenciaristas ensinam que a evolução das modernas conquistas sociais vem produzindo acentuada modificação na ciência e no regime penitenciário, impondo princípios de humanidade para com os delinqüentes, não só em benefício do próprio indivíduo, como também da coletividade (AE, janeiro de 1945, p. 2)

Já especificamente em relação aos presídios femininos, os penitenciaristas tiveram um papel relevante em sua estruturação, nas delineações da instituição, bem como na importância da separação dos espaços de encarceramento masculino e feminino. Lemos Britto, Victório Caneppa, Roberto Lyra e Cândido Mendes são exemplos de penitenciaristas brasileiros que se preocuparam com a distribuição de mulheres e homens em estabelecimentos distintos, como poderá ser verificado de maneira mais aprofundada nos próximos capítulos.

Cândido Mendes de Almeida Filho foi um jurista brasileiro, nascido em 1866, que participou de maneira ativa dos debates e das práticas em política criminal no início do século XX. Uma de suas grandes bandeiras era "elevar os nossos cárceres à altura da civilização brasileira" o que buscou fazer com a criação do Conselho Penitenciário e da Inspetoria Geral Penitenciária (Arquivos Penitenciários do Brasil, vol I, 1940, p. 68). Em seu discurso na ocasião da criação do Conselho Geral Penitenciário ${ }^{38}$, em dezembro de 1924, Cândido Mendes destaca que o sistema penitenciário brasileiro era vergonhoso, e que não era possível se falar em um regime penitenciário nacional. Era a favor da criação de um regime especial brasileiro, que

38 O Decreto No 16. 665, de 6 de Novembro de 1924 criou os Conselhos Penitenciários. Os conselhos deverão intervir (verificar a conveniência da concessão de Livramento Condicional; tratar de liberdade vigiada em caso de menores delinqüentes); manifestar-se sobre graça, indulto e comutação de pena. Já o Governo Federal, com o intuito de obter recursos financeiros para a efetivação das reformas penais, criou o selo penitenciário, bem como a inspetoria geral, por decreto $\mathrm{n}^{\circ} 24.797$ de 14 de julho de 1934 . O decreto 1.441 de 8 de fevereiro de 1937 regulamentou esse decreto, tratando da organização da inspetoria. 
respondesse às demandas do país e "à índole dos nossos criminosos” (Arquivos Penitenciários do Brasil, vol I, 1940, p. 264).

Foi incentivador das penitenciárias agrícolas, pois acreditava que a agricultura, sendo a base da produção nacional, seria o principal meio de reinserção do egresso na vida social. Além disso, defendeu assiduamente a regulamentação do livramento condicional, junto com outros membros do Conselho Geral Penitenciário, do qual foi o primeiro presidente. De acordo com Queiroz, Cândido Mendes foi um "representante da modernização conservadora do direito penal brasileiro", sendo defensor de reformas “(...) que fossem modernizantes (intelectualmente) e conservadoras (socialmente)". Isso significa que ao mesmo tempo em que via o sistema penal como forma de contenção das massas proletárias, era a favor da construção de instituições modernas e condizentes com as teorias em voga (QUEIROZ, 2007, pp. 176 e 177).

Em relação às mulheres presas, em 1928, Cândido Mendes, então presidente do Conselho Penitenciário do Distrito Federal, em seu trabalho As Mulheres Criminosas no Centro mais Populoso do Brasil, apresenta, como já mencionado anteriormente, estatísticas que revelam a situação do aprisionamento de mulheres no sudeste do país, entre 1926 e 1927. Aponta detalhes como porcentagem das sentenciadas e processadas em cada estado analisado, o nome das sentenciadas, e que a maioria era ré primária. Além disso, recomendava a criação de um estabelecimento agrário para mulheres, pois:

sendo em grande maioria longas as penas a que foram condenadas as mulheres criminosas, em conseqüência da gravidade do crime comettido, evidente é a vantagem da penitenciária agrícola especializada, na qual poderiam ser educadas, na prática de trabalhos ruraes e agrícolas próprios para mulheres, como sejam a avicultura, a apicultura, a sericultura, a pequena lavoura, a jardinagem, floricultura e industria de conservas (ALMEIDA, 1928, p. 6293).

Representou o país em inúmeros congressos internacionais penitenciários, dentre eles o IV Congresso Internacional Penitenciário de São Petersburgo , em 
1890, e os Congressos Penitenciários de Haia, Paris, Praga e Berlim. Faleceu em 1939, sendo relembrado a cada discurso dos conselheiros penitenciários durante os anos que seguiram o seu falecimento.

José Gabriel de Lemos Britto é personagem central dentre os penitenciaristas. Cadastrado na Enciclopédia de Literatura Brasileira ${ }^{39}$ como orador, poeta, teatrólogo, romancista, jornalista, jurista, sociólogo, historiador, criminologista, membro da Academia Carioca de Letras pode ser considerado um dos principais nomes do universo penitenciário brasileiro na primeira metade do século XX. Nascido em 1886 em Salvador, diplomou-se em Direito pela Faculdade da Bahia em 1907. Sua preocupação com as questões carcerárias o acompanhou desde a mocidade, o que fica claro em sua palestra denominada A Evolução do Sistema Penitenciário Brasileiro nos últimos 25 anos, proferida a pedido do Instituto da Ordem dos Advogados de São Paulo, publicada nos Arquivos:

eu vinha de longa data pedindo um pouco de atenção para os cárceres brasileiros e para os seus habitantes. Nos bancos acadêmicos havia agitado esse problema e num pequeno livro que publiquei em 1908, na Baía, disse verdades candentes sobre o que ali se verificava em matéria de prisões. Vali-me da imprensa para expandir meu pensamento, e de volta da primeira missão que tive no estrangeiro, como delegado ao Primeiro Congresso Americano da Criança, publiquei o opúsculo intitulado Colônias e prisóes no Rio do Prata, ao qual se seguiu outro, Um Problema Gravissimo, sobre colônias correcionais e tribunais para menores. Em 1919, quando o mundo começava a refazer-se da primeira grande guerra, transferi-me para o Rio, e ai, apresentado ao Ministro da Justiça, pelo saudoso Dr. Miguel Calmon, abordei o problema que tanto me preocupava (...) (APB, 1946, p.17).

Desde a publicação de seu, já mencionado, relatório sobre o sistema penitenciário nacional, baseado em pesquisa feita por ele entre 1923 e 1924, José Gabriel

39 Informação encontrada no sítio: http://www.literaturabrasileira.ufsc.br/Consulta/Autor_nav. php?autor $=10622$, acesso em 19/07/2010. 
de Lemos Britto tornou-se referência quando em pauta o sistema carcerário nacional, tendo escrito inúmeros artigos, pareceres e livros sobre este e outros temas. Dentre os livros que publicou estão: Psychologia do Adulterio de 1933; o já mencionado $O s$ systemas penitenciarios do Brasil, de 1924; A Gloriosa Sotaina do Império: Frei Caneca, de 1937; O Crime e os Criminosos na Literatura Brasileira, de 1946; e A questão sexual nas prisóes. Foi professor de direito nas faculdades de direito e de engenharia da Bahia, e professor na Faculdade Nacional de Direito no Rio de Janeiro. Sucedeu o jurista Cândido Mendes na presidência do Conselho Penitenciário do Distrito Federal e na Inspetoria Geral Penitenciária, tendo sido, enquanto presidente, responsável pela edição dos Arquivos Penitenciários do Brasil durante a década de 1940.

Assim como Cândido Mendes, Lemos Britto acreditava que a reforma carcerária era urgente, e que não era possível falar em uma nação civilizada com os cárceres brasileiros no estado em que se encontravam. Era favorável à individualização da pena, tese defendida pelos positivistas criminais, uma vez que era antiquado prescrever a mesma pena para crimes da mesma espécie (LEMOS BRITTO, 1924, p.16). O criminoso deveria ser considerado, devendo haver uma prescrição individualizada. Em sua obra Os systemas penitenciarios do Brasil, Lemos Britto se coloca veementemente contra a aplicação, pelo magistrado, de uma pena determinada e certa para cada indivíduo criminoso. A seu ver, não é possível ao magistrado saber se aquela pena irá ou não ser suficiente para determinado condenado. Assim, se coloca a favor das penas relativamente indeterminadas, ou seja, a favor da fixação, pelo juiz na sentença condenatória, do mínimo e do máximo da pena que o réu deverá/ poderá cumprir (LEMOS BRITTO, 1924).

Sua afinidade com a Antropologia Criminal aparece bastante na obra de 1924, como é possível verificar na seguinte citação: "o crime deve ser estudado de accôrdo com os conselhos e os principios da escola positiva. O criminoso há de ser tratado por processos racionaes, dentro de uma legislação que faça a pena elástica, dúctil, adaptável ao individuo". Sobre a abordagem do criminoso como um doente e do cárcere como um espaço de cura, típicos da antropologia criminal, Lemos Britto salienta ainda que "a pena carece de adaptar-se ao criminoso e não ao crime. Deve ser 
remédio, e não a expressão de uma vindicta social" (LEMOS BRITTO, 1924, p. 24).

Lemos Britto mostrava-se inconformado com o fato de que ao mesmo tempo em que muitos cursos de direito e medicina ensinavam as mais modernas teorias criminológicas e técnicas penitenciárias, o Estado Brasileiro não construía cárceres condizentes com essas teorias. As masmorras continuavam existindo, sendo muitas das prisões nacionais depósitos insalubres de pessoas. Em seus pronunciamentos públicos, como presidente do Conselho Penitenciário, e nos inúmeros textos escritos ao longo de sua carreira, é possível verificar que a regeneração e a readaptação social do sentenciado, bem como a defesa social eram, a seu ver, as principais funçôes da pena.

Em relação ao encarceramento feminino, Lemos Britto exerceu um papel importante no período de criação dos primeiros estabelecimentos prisionais para mulheres no país. Desde seu relatório escrito em 1924 chamava a atenção para a situação degradante do aprisionamento de mulheres, e sugeria a construção de espaços próprios para elas. Durante as negociações para a construção do Penitenciária de Mulheres de Bangu, em 1941, participou ativamente, como presidente do Conselho Penitenciário, tanto da criação do regulamento interno da casa, quanto da escolha das Irmãs administradoras e do regime penitenciário a ser adotado na Instituição ${ }^{40}$. Em sua conferência denominada As Mulheres Criminosas e seu Tratamento Penitenciário, publicada em 1943 pela Imprensa Oficial, chamava a atenção para a necessidade de separação urgente dos cárceres femininos e masculinos, defendendo a construção de estabelecimentos só para mulheres em terrenos separados dos homens.

Vitório Caneppa, por sua vez, foi diretor de estabelecimentos prisionais no Distrito Federal e no Estado do Rio de Janeiro - da Colônia Penal de Ilha Grande, durante cinco anos, e da Penitenciária Central do Distrito Federal. Nascido no Rio Grande do Sul, cursou Escola de Guerra do Realengo, e a Escola de Intendentes, tornando-se militar de carreira, chegando ao posto de capitão do exército ${ }^{41}$. Foi um dos idealizadores da Penitenciária Central do Distrito Federal, tendo acompanha-

\footnotetext{
$40 \quad$ Estes temas serão explicitados de maneira aprofundada no quarto capítulo.

41 O posto de maior hierarquia que acompanha o nome de Victório Caneppa é o de "capitão". Como não há uma biografia sobre ele, não é possível saber se chegou a ocupar cargos superiores a este no exército.
} 
do de perto a transformação da antiga Casa de Correção na penitenciária. Fez parte do Conselho Penitenciário do Distrito Federal, bem como foi o primeiro presidente da Associação Brasileira de Prisões, criada em 1952. Durante o tempo em que foi diretor da Penitenciária Central do Distrito Federal - de 1944 a 1946 e de 1951 a $1955^{42}$ - criou o periódico A Estrela, tendo contribuído ativamente com artigos, relatos de viagens a congressos, relatos de visitas a penitenciárias brasileiras e de diversos países, registros oficiais, comentários sobre temas referentes ao sistema prisional e à Penitenciária Central do Distrito Federal, bem como com impressões pessoais sobre temas variados. Nos anos do Governo Eurico Gaspar Dutra, entre 1946 e 1951, foi afastado do cargo de diretor, voltando à direção com o retorno de Getúlio Vargas ao poder, em 1951.

Pelo que é possível notar nas páginas de $A$ Estrela, Caneppa foi um diretor extremamente personalista e centralizador. Sua imagem aparecia constantemente nas páginas da revista, sempre associada a melhorias na Penitenciária, a eventos sociais beneficentes em prol dos presidiários e de suas famílias e a eventos científicos nacionais e internacionais de criminologia e penitenciarismo. Seu nome era repetido, não só em todas as capas das edições de $A$ Estrela como sendo seu fundador, mas ao longo de diferentes colunas do periódico, na maioria das vezes em exaltação à sua figura. A Estrela retrata um diretor que combinava em sua gestão a extrema disciplina, provavelmente aprendida no Exército, com um humanismo cristão, que enxergava o preso como ser humano e, portanto, digno de respeito e passível de regeneração.

Tamanha eram as referências a Caneppa na revista que o jornalista José Arthur Rios, publicou no jornal a Tribuna da Imprensa de 03 de janeiro de 1952, uma crítica ferrenha ao diretor da Penitenciária Central do Distrito Federal, acusando-o de ser personalista e de $A$ Estrela passar a impressão de que o presídio era um lugar delicioso. Além disso, criticava a quantidade de militares no local, não só alocados em cargos na penitenciária, como participando de eventos no interior desta. Nas palavras do jornalista:

$42 \quad$ É o que indica $A$ Estrela, mas não há nenhum registro oficial dessa data de 1955. 
a penitenciária que sua revista apresenta é alguma coisa próxima do paraíso, um céu aberto, com futebol, eleições e centros de pesquisa científica. É bem possível que muita gente, lendo as páginas cor de rosa dessa revista, comece a pensar seriamente em tornar-se pensionista do Capitão Caneppa (AE, janeiro de 1952, p. 32).

$\mathrm{O}$ artigo do Jornalista foi publicado integralmente na revista $A$ Estrela, juntamente com a resposta de Caneppa a ele, ressaltando, dentre outros, que a função da pena é a recuperação de indivíduos, de modo a permitir sua regeneração moral, por isso o tratamento dado aos presos na Penitenciária Central do Distrito Federal. Além disso, Caneppa convida José Arthur Rios a visitar a Penitenciária "a qualquer hora do dia ou da noite", sem hora marcada, para que pudesse verificar sem maquiagens o trabalho lá realizado (AE, janeiro de 1952, p. 32).

Para além dessa discussão, é possível apontar inúmeros elogios feitos a Caneppa e sua administração, oriundos de acadêmicos, juristas, artistas, visitantes da Penitenciária bem como de comissões de avaliação. O dramaturgo Pedro Bloch, que em 1952 foi assistir a uma peça sua, chamada As Mãos de Eurídice, encenada pelos presos no auditório da Penitenciária, ficou impressionado com o ambiente e escreveu um relato muito emocionado de sua visita, frisando que, naquele lugar, as "coisas" pareciam de fato ser organizadas (AE, jul/set. de 1952, pp.58 e 59). Dentre outros exemplos, há o relatório de uma Comissão Parlamentar que, após ter chegado de surpresa à Penitenciária, elaborou texto extremamente elogioso à direção de Caneppa e aos trabalhos lá realizados, inclusive o estabelecimento de um espaço de visita íntima, denominado "Pavilhão A" ${ }^{43}$, instalado por Caneppa em 1944 e reinstalado em 1951 com seu retorno à direção.

No que diz respeito à sua contribuição para o debate sobre o aprisionamen-

43 O "Pavilhão A" era um espaço experimental de visita íntima masculina na Penitenciária Central do Distrito Federal, com o objetivo de verificar se a prática de relações sexuais influenciava positivamente o comportamento do sentenciado. As visitantes deveriam ser as companheiras dos condenados com direito à visita. Caneppa incentivava a visita íntima, prática que combateria o onanismo, ao qual era contrário, e "acalmaria” os detentos. No entanto, de acordo com Caneppa em artigo denominado O problema sexual nas prisóes, muitos presos não queriam expor suas mulheres à visita, pois não achavam o local adequado (AE, Junho de 1951, s/p). 
to de mulheres, é possível pontuar alguns artigos e relatórios publicados nos Arquivos Penitenciários do Brasil e na revista $A$ Estrela, nos quais o autor tanto relata a situação de alguns presídios femininos visitados no Brasil e em outros países, quanto discute a criminalidade feminina e suas peculiaridades ${ }^{44}$. Além disso, vale destacar que Caneppa é considerado o primeiro diretor da Penitenciária de Mulheres de Bangu no Rio de Janeiro, inaugurada em 1942, uma vez que a Penitenciária de Mulheres era vinculada à Penitenciária Central do Distrito Federal. Isso significa que apesar de não estar no dia a dia da instituição, que era administrada internamente pelas Irmãs do Bom Pastor, Caneppa era o diretor geral de todas as penitenciárias vinculadas à Penitenciária Central do Distrito Federal, dando a última palavra quando se fizesse necessário.

Por fim, vale mencionar Roberto Lyra que, apesar de não reivindicar para si a categoria de penitenciarista, contribuiu para o debate acerca dos presídios femininos no país e participou ativamente do Conselho Penitenciário do Distrito Federal. Jurista brasileiro, redator de alguns volumes dos Arquivos Penitenciários do Brasil, contribuiu assiduamente para esse periódico, principalmente com artigos e comentários sobre a legislação penal. Membro do Ministério Público do Distrito Federal, jornalista, criminólogo e professor de direito penal e criminologia na Faculdade Nacional de Direito, Lyra foi um dos membros da comissão revisora do Código Penal de 1940. Publicou, dentre outros, Novas Escolas Penaes, de 1936; Noçôes de Direito Criminal, de 1945; O Socialismo para o Brasil, de 1962; e Criminologia, de 1964. Considerado por colegas de profissão e biógrafos ${ }^{45}$ um socialista utópico, de acordo com o historiador Carlos Henrique Serra, “(...) o socialismo professado por Lyra é ambíguo e possui um intenso caráter sentimental e idealista. É um socialismo romântico, em grande medida, por carecer de um embasamento teórico-filosófico. Lyra realiza uma combinação entre o nacionalismo, o positivismo e o cristianismo" (SERRA, 2006 p.159).

\footnotetext{
$44 \quad$ Ver: APB, 1941, pp. 257 e 258; AE set/out de 1951, pp. 23 e 24.

45 O historiador Carlos Henrique Serra analisou a obra de Roberto Lyra em seu doutorado História das idéias jurídico-penais no Brasil: 1937-1964 (Universidade Federal Fluminense, 1997). Lopo Alegria, aluno de Lyra, escreveu, em 1984, uma biografia do autor, chamada Assim foi Roberto Lyra. Já Evaristo Costa publicou Professor Roberto Lyra: o Socialismo para o Brasil - cristianismo, nacionalismo, democracia, de 1962 (SERRA, 2006, p. 154).
} 
Ao longo de sua carreira Lyra se aproximou cada vez mais da criminologia se distanciando da dogmática jurídica, tendo inclusive sido um dos primeiros juristas brasileiros a considerar a análise sociológica fundamental à criminologia. Lyra ressaltava que o direito deveria atentar mais para a realidade, para a sociedade, de modo a dar respostas eficientes para questões do presente. Nesse sentido, acreditava na potencialidade transformadora do direito quando associado à sociologia. Ao dizer que “os juristas puros são escafandristas do vazio; os filósofos puros são comensais das nuvens" o autor propunha um equilíbrio entre os saberes, compensando prática e teoria (LYRA, apud SERRA, 2006, p. 169).

Os penitenciaristas tiveram um papel importante na prática penitenciária brasileira, em especial ao longo das décadas de 1930, 1940 e 1950. Foram, em grande medida, responsáveis por levantar questões referentes às técnicas punitivas em voga e por incitar reformas penitenciárias que poderiam colocar o país dentre aqueles que faziam parte de uma "vanguarda punitiva". Victório Caneppa, Lemos Britto, Roberto Lyra, Cândido Mendes e outros aparecerão, em maior ou menor grau, ao longo do presente trabalho, uma vez que seus posicionamentos e reflexões acerca do aprisionamento, em especial de mulheres, não só permitem retomar aspectos importantes das origens das instituições prisionais femininas, como também enxergá-las no interior de um espectro mais amplo que é o de um momento fecundo das teorias e práticas punitivas nacionais.

\section{PRÁTICAS PUNITIVAS}

Aqueles preocupados com as questões prisionais na segunda metade do século XIX se desassossegavam cada vez mais com a imagem que o Brasil apresentava no exterior, já que os cárceres nacionais eram masmorras insalubres, onde a violência, a fome e as doenças conviviam, cotidianamente, com os condenados e os guardas. Como solução, em um primeiro momento, as Casas de Correção, construídas a partir da década de 1850 , representaram um passo importante para a mudança do quadro punitivo nacional, introduzindo a execução das penas com trabalho, volta- 
das àqueles para os quais havia sido prescrita, pelo juiz, pena laboral. Finalmente o condenado teria a possibilidade de, com o trabalho e as rígidas regras praticadas, ser corrigido e então voltar recuperado à sociedade. No entanto, o dia a dia das casas de correção foi marcado por insurreições e violências, o que adiou o sonho de alguns de solucionar os problemas prisionais e tornar o Brasil referência punitiva dentre os países "civilizados".

As Casas de Correção representavam um esforço no sentido de dar ao aprisionamento uma função, que não meramente a de retirar o preso do convívio social. Na Europa, desde o século XVI havia casas de correção voltadas para o treinamento laboral, tendo aumentado o número de estabelecimentos desse tipo principalmente após a revolução industrial, no século XVIII, de modo a receber o contingente de reserva fabril que não estava ativo (SANT'ANNA, 2009, p. 296). De acordo com Salla, a partir da década de 1870, principalmente a tentativa, iniciada com as Casas de Correção, de adequar os espaços prisionais para colocar em prática os modelos punitivos previstos em lei, bem como a reflexão sobre os modelos ideais de cumprimento das penas eram algumas das questões mais recorrentes entre os que refletiam a respeito do cárcere. Todo esse debate era permeado, como não poderia deixar de ser, por uma discussão teórica intensa.

Os sistemas de Filadélfia e Auburn eram os mais considerados quando da estruturação dos prédios e dos códigos disciplinares dos estabelecimentos prisionais brasileiros. O primeiro prezava pelo isolamento completo do preso em uma solitária, sempre em silêncio absoluto, para que tivesse de conviver consigo mesmo, buscar o arrependimento e o remorso. $\mathrm{O}$ trabalho aparecia como algo terapêutico, e não tinha um objetivo econômico. Silêncio, prece, meditação, arrependimento, isolamento celular eram palavras chave para esse modelo de encarceramento. De acordo com Salla, no modelo de Filadélfia, "a mesma capacidade de uso do arbítrio que leva o indivíduo ao crime o conduz também à sua regeneração. Há uma suposição implícita, de cunho igualitário, de que todos os indivíduos são capazes de usar livre e conscientemente o seu arbítrio" (SALLA, 1999, p. 111). Pavarini e Melossi, ao analisarem a origem do sistema penitenciário nos Estados Unidos no século XIX, afirmam 
que, para seus idealizadores, o confinamento solitário

(...) era capaz de resolver qualquer problema penitenciário; impedia a promiscuidade entre os detidos, que se revelava um fator criminógeno de efeito desastroso, além de promover, por meio do isolamento e do silêncio, o processo psicológico de introspecção que era considerado o veículo mais eficaz para o arrependimento (MELOSSI e PAVARINI, 2006, p. 189).

O modelo de Auburn foi pensado posteriormente ao de Filadélfia ter sido implementado em algumas cidades estadunidenses. Isso porque, com o aumento na demanda por mão de obra naquele país, a necessidade de tornar o cárcere produtivo entrou em pauta novamente ${ }^{46}$. Esse sistema previa o isolamento celular noturno e o trabalho coletivo, em silêncio, durante o dia. A Reforma moral se daria por meio do trabalho rigoroso e disciplinado ao longo do dia, e a meditação solitária e silenciosa durante a noite. Para Melossi e Pavarini, “(...) a originalidade do novo sistema consistia na introdução de um tipo de trabalho de estrutura análoga àquela então dominante na fábrica” (MELOSSI e PAVARINI, 2006, p. 191).

No Brasil, as Casas de Correção e as penitenciárias que as substituíram nasceram sob o debate de qual seria o modelo mais adequado aos cárceres nacionais. De um lado o isolamento completo previsto pelo sistema de Filadélfia e, por outro, o isolamento noturno com trabalho diário proposto pelo sistema de Auburn. Buscava-se conciliar a meditação com o trabalho, que deveria ser voltado antes para a disciplina que para o lucro. Conciliar trabalho, disciplina, silêncio, isolamento e oração poderia ser uma boa fórmula para combater o crime e recuperar o criminoso. Salla, ao refletir acerca da intensa participação dos diretores dos estabelecimentos prisionais nos debates sobre o melhor sistema de funcionamento prisional a ser colocado em prática no Brasil, ressalta que:

46 Novamente, pois, antes da criação do modelo de Filadélfia, já tinham sido colocados em prática, nos Estados Unidos, workhouses e casas de correção com trabalho obrigatório e gerador de lucro (MELOSSI e PAVARINI, 2006, pp. 184 a 188). 
no início da década de 1870, embora surgissem defensores radicais da adaptação de nossas prisões ao modelo de isolamento absoluto, o que predominou, entre estudiosos e administradores, foi a adesão ao sistema irlandês ou progressivo, que conciliava, com alguns acréscimos, o modelo auburiano e o de Filadélfia. Solução que se ajustou bem ao Brasil, uma vez que neste período, eram revalorizadas, na Europa, as concepções em favor do isolamento absoluto como melhor caminho para o tratamento penal. Mantinha-se, assim, afinado com as principais tendências no plano mundial, e, ao mesmo tempo, não abandonava a preocupação em fazer com que a prisão exercesse, por meio do trabalho, um claro papel de disciplinamento (SALLA, 1999, p. 112).

No entanto, o cotidiano das casas de correção não funcionava como previsto e como almejavam seus principais ideólogos. Isso fica claro nos estudos que analisam o aprisionamento na época, bem como na leitura de alguns relatórios, artigos, pareceres e opiniões sobre a situação prisional no Brasil, escritos no período analisado. ${ }^{47}$ Eram maiores os debates e os planos que a sua realização prática. Construir uma nação moderna implicava mais discutir os temas de maneira científica, refletir sobre as instituições e criar leis em consonância com outros países europeus e americanos do que propriamente investir na sua concretização ou aprimoramento. Salla chama a atenção para essa discrepância entre o discurso, o papel e a prática, realçando que o trânsito dos diretores e funcionários da Casa de Correção e, posteriormente, da Penitenciária da Capital, pelas instâncias de debate e pelo cotidiano prisional não garantia uma convergência entre teoria e prática (SALLA, 1999). Já de acordo com Sant'Anna:

apesar de todo o progresso da ciência penitenciária, do intercâmbio com experiências internacionais que comprovam a preocupação com o estabelecimento penitenciário na maioria dos países europeus e americanos, não havia investimento do poder público no interior das prisões brasileiras (SANT'ANNA, 2009, p. 309).

47 Ver SALLA, 1999; SANT'ANNA, 2009; FERLA, 2009. 
Estabelecimentos prisionais adequados deveriam ser construídos para que fosse possível colocar em prática um novo tempo penitenciário. Para tanto era necessário não apenas investimento público, mas também que o debate sobre as formas punitivas, o crime, o criminoso e as leis penais fosse seguido de uma prática igualmente de vanguarda.

Os esforços para mudar a situação carcerária nacional e atualizar o quadro punitivo brasileiro não foram poucos. Um exemplo disso foi o projeto de lei apresentado nos últimos anos do século XIX por Paulo Egydio, que propunha uma reforma penitenciária capaz de colocar o Brasil na vanguarda das técnicas punitivas. Os médicos, principalmente os psiquiatras, recebiam atenção especial no projeto, já que as penitenciárias seriam locais de cura e tratamento terapêutico. Profissionais especializados eram importantes para colocar em prática as minuciosas técnicas de classificação, medicalização e produção de laudos. Nesse sentido, Paulo Egydio propunha igualmente que fosse criada uma escola penitenciária, que incluísse, dentre outras, as disciplinas: antropologia geral e criminal, direito penal, psicologia, psiquiatria e história penitenciária (SALLA, 1999, pp. 161 a 167). Este projeto não foi colocado em prática, mas, ainda na primeira década do século XX, foi autorizada a construção de uma penitenciária em São Paulo com capacidade para abrigar mais de mil condenados e com o objetivo de ser um espaço de disciplinamento, tratamento, individualização da pena, produtividade do condenado, trabalho, ordem e de prática científica. (SALLA, 1999, pp. 178 a 183).

Inaugurada em abril de 1920, a Penitenciária do Estado colocava São Paulo na tão almejada modernidade punitiva. Disciplina, trabalho, silêncio e regeneração eram lemas da casa, que recebia condenados da capital e de outras regióes do estado. Ao ser recolhido à Penitenciária do Estado, o condenado passava a ser observado nos mínimos detalhes pelos funcionários e especialistas que compunham os seus quadros, sendo avaliado não só o seu comportamento durante o tempo de estadia na Penitenciária, mas também realizada uma anamnese psicológica com o objetivo de mapear traços comportamentais do indivíduo antes da condenação. Sua biografia era de suma importância para a compreensão do comportamento delituoso, as- 
sim como seus antecedentes familiares. Alcoolismo, epilepsia e outras doenças psicológicas, manifestadas tanto no sentenciado, quanto em algum parente, poderiam indicar degenerescência genética com influência no comportamento delinquente.

Elogiada por intelectuais brasileiros e estrangeiros, a Penitenciária do Estado era um exemplo a ser seguido no país, já que era considerada a primeira instituição capaz de cumprir o que estava previsto no Código Penal de 1890, como a implementação do modelo penitenciário irlandês ${ }^{48}$. Muitas pessoas visitavam diariamente a Penitenciária, que simbolizava, juntamente com outras instituições, como o Hospital do Juqueri, a vanguarda terapêutica paulistana em relação aos demais estados do país ${ }^{49}$. Vale sublinhar que a Penitenciária foi planejada com base nos princípios da Antropologia Criminal, sendo um espaço onde finalmente os preceitos teóricos desta escola poderiam ser testados e praticados. Nesse sentido, Salla pontua que "os seguidores das correntes criminológicas influenciadas por Lombroso e Ferri, principalmente, que desfrutavam no Brasil de ampla simpatia nos meios jurídicos e médicos, encontravam, enfim, um meio concreto de transformar suas propostas em práticas efetivas" (SALLA, 1999, p. 201).

A violência institucional, no entanto, não sumiu com a modernização da proposta e do edifício. Salla (1999, pp. 253 a 293), ao analisar laudos, prontuários e documentos relativos às duas primeiras décadas de existência da Penitenciária, pontua atrocidades cometidas no seu interior. Castigos físicos, punições, tempos prolongados nas solitárias sem luz e higiene, jejum, dentre outros, são relatados pelo autor. As contradições inerentes à instituição apareciam também, ainda que raramente, na mídia e nos relatos de visitantes, o que desmoralizava a Penitenciária e seus dirigentes (SALLA, 1999, pp. 216 a 221). Por outro lado, como não poderia deixar de ser, os internos não recebiam com passividade o tratamento a eles dispensado no cotidiano prisional. Houve muitos exemplos de resistência, revoltas individuais e coleti-

48 Salla dá exemplos de elogios ao estabelecimento publicados em revistas estrangeiras, como aqueles feitos por Ernesto Bertarelli, professor da Universidade Pavia-Milão, em 1922, e pelo o engenheiro Enrico Carrara, em 1926 (SALLA, 1999, p. 196).

49 O antropólogo francês Claude Lévi-Strauss visitou a Penitenciária do Estado na década de 1930 (SALLA, 1999, p.325). 
vas, tentativas e práticas de suicídio por parte dos sentenciados.

Nesse contexto, apesar de todo o aparato científico que fora construído e toda a pompa de ser o que havia de mais moderno no momento, as críticas de que os velhos tempos punitivos continuavam em prática maculavam a imagem da Penitenciária. A contradição entre a moderna ciência penal que emanava dos compêndios de medicina-legal, direito penal e antropologia criminal e as prisões do início do século XX, convivia dentro dos muros da Penitenciária do Estado. Se durante a primeira década de existência os elogios se sobrepunham às críticas, o mesmo não pode ser dito dos tempos seguintes, quando as opiniões de especialistas divergiram e propostas de reformas surgiram.

Vale ressaltar que Salla pontua constar no projeto original da Penitenciária do Estado de São Paulo, o pavilhão para mulheres, mas, no entanto, à época da sua inauguração, em 1920, tal pavilhão fora usado como hospital e enfermaria, tendo sido adiada por mais de vinte anos a inauguração da penitenciária para mulheres (SALLA, 1999, p. 181). O Presidio de Mulheres de São Paulo nasceu somente no ano de 1941, de maneira improvisada, pois se instalou na antiga residência dos diretores no terreno da Penitenciária do Estado no bairro do Carandiru. ${ }^{50}$

A Penitenciária do Estado de São Paulo, nos anos 1940, já era considerada ultrapassada, como mostra o seguinte trecho de um artigo publicado nos Arquivos Penitenciários do Brasil no qual o autor, ao refletir sobre a importância da criação de uma penitenciária modelo no estado do Rio Grande do Sul, notava que a de São Paulo não era mais modelo, justamente por não dialogar com os mais modernos métodos de humanização prisional:

50 Tal movimento de adaptar edifícios antes usados para outras funções para abrigar as mulheres condenadas é, ainda hoje, prática corrente. O próprio prédio da Penitenciária do Estado de São Paulo, inaugurado na década de 1920 para abrigar homens, foi transformado em 2005 na Penitenciária Feminina de Sant'Anna, hoje considerado o maior presídio feminino da América Latina, com mais de 2500 mulheres. 
a própria penitenciária de São Paulo, em face dos requisitos modernos de regeneração, está muito distante de uma penitenciária modelo. Penitenciária modelo não é suntuosidade. Não é possuir salas amplas, divertimento para os detentos, ou campeonatos para distrair-lhes o ócio. Mas uma competente orientação científico jurídica para o aperfeiçoamento moral do delinqüente e uma assistência técnica efetiva, afim de que, após abandonar o presídio, seja um homem honesto e um profissional apto (APB, 1942c, p. 194).

Lemos Britto, no primeiro volume dos Arquivos Penitenciários do Brasil, publicado em 1940, ao falar das funções do cárcere, ressalta que com o propósito de conseguir a regeneração dos criminosos, deveria ser organizado o plano das reformas penitenciárias no país (APB, 1942c, p. 22). Para regenerar era necessário, em primeiro lugar, tratar os presos com humanidade, não como delinqüentes irrecuperáveis, mas como pessoas que erraram e que, ao cabo de um tempo, deveriam retornar como cidadãos à sociedade. A valorização do investimento em um cárcere humanizado fica clara em relatório de Lemos Britto sobre as realizações penitenciárias no Distrito Federal, no qual o autor frisa a importância do fim dos uniformes zebrados na Casa de Correção do Rio de Janeiro, o fim dos números estampados nas roupas dos sentenciados bem como do chamamento por número, como forma de respeito à "dignidade humana". O autor se baseia na noção de que o uniforme zebrado e os números, "do tempo de 'El Rei' (...) remontam à ideia de vingança outrora atribuída à pena”. Não há, a seu ver, nada mais cruel que a despersonalização da pena, que massificava os aprisionados, tratando todos de igual maneira. No entanto, segundo o jurista, tais uniformes zebarados poderiam continuar sendo usados por indivíduos da "classe inferior" que seriam os presos insubordinados e indisciplinados, o que denota a hierarquização entre grupos de aprisionados (APB, 1942c, p. 136).

Impressões deixadas pelos juízes do Tribunal de Apelação do Distrito Federal, em 1944, no livro de visitas da Penitenciária de Mulheres de Bangu mostram o quanto o discurso da humanização da pena estava na ordem do dia para os operadores do direito. Segundo consta do livro, os visitantes tiveram 
(...) da visita a este estabelecimento uma impressão de agradável surpresa, pois não o sabíamos tão modelarmente instalado e dirigido. E sentimos também como que um grande conforto moral, por verificarmos que a pena que aplicamos é executada como nós entendemos que deve ser, isto é, sem ódio ou prevenção contra o delinqüente, mas, ao contrário, considerando-o como um semelhante (AE, janeiro de 1945, s/p).

Uma nota, publicada na revista $A$ Estrela, tratando da primeira reunião da Associação Brasileira de Prisões realizada no Salão Nobre da Penitenciária Central do Distrito Federal em 1952, cujo objetivo principal era o estudo dos problemas penitenciários à época, mostra a importância assumida pela humanização da pena como forma de adequar as prisões nacionais às recomendações da Organização das Nações Unidas sobre tratamento penitenciário ${ }^{51}$. Um dos focos centrais da reunião era justamente estudar maneiras que possibilitassem oferecer aos presos tratamentos mais humanos de modo a impedir que “(...) aqueles que erraram não sejam considerados animais, e como tal submetidos a castigos físicos e toda sorte de vexames" (A Estrela, ano II, Rio de Janeiro, novembro/dezembro de 1952, No 19 e 20P. 1). Já um artigo não assinado, publicado na revista $A$ Estrela sobre o serviço de Assistência Social na Penitenciária Central do Distrito Federal, ressaltava em relação à humanização da pena que:

(...) chegaram-nos os que nos desataram os grilhões; proscreveram os suplícios, arrancaram das nossas testas, peitos e costas os algarismos; desafogaram-nos o peito; deixaram-nos ver os entes queridos, ausentes e distantes, ascultaram nossos corações e abraçaram-nos profundamente como Irmãos; choraram conosco as lágrimas da saudade por tamanha ausência, trouxeram-nos o calor de suas almas, o amor, a fé e a esperança - por-

51 A International Penal and Penitentiary Commission, criada em 1872, com a função original de coletar dados estatísticos penitenciários e de estimular reformas penitenciárias foi transferida para a Organização das Nações Unidas em 1950, que deveria organizar a cada cinco anos um encontro denominado UN Congresses on the Prevention of Crime and the Treatment of Offenders, tendo sido o primeiro realizado em 1955 . Na ocasião do primeiro Congresso foram criadas as Regras Minimas para o Tratamento dos Presos. http://archives.un.org/ARMS/ sites/ARMS/uploads/files/ag_010.pdf. Acesso em julho de 2011. 
que passamos a viver juntos, como doentes é verdade, mas com humanidade e com respeito. (...) É verdade que haverá sacrifício e mesmo sofrimento; mas nunca desventura, dilaceramento, cisão ou intromissão. (...) A prisão não mais deverá significar “casa dos suplícios" ou "inferno de Dante" (AE, Abril de 1951, s/p).

$\mathrm{O}$ investimento em uma arquitetura penitenciária moderna igualmente fazia parte dos projetos de humanização da pena ${ }^{52}$. Um prédio novo, sem grandes muros e sem pesadas grades, era uma maneira clara de mostrar que as pessoas que habitavam os presídios não eram tão perigosas a ponto de serem absolutamente isoladas, bem como de refletir a ideologia carcerária humanizada em sua fachada. Quanto menos as instituições penais se parecessem com presídios, melhor seriam. Caneppa, em artigo no qual reflete sobre a influência da arquitetura no progresso penitenciário fala da importância de relacioná-la à administração prisional. Em suas palavras

pesados muros, parecendo verdadeiros 'fortes', produzirão, indubitavelmente, reações psiquicas, até mesmo no corpo de funcionários, reações essas que atuam fortemente contra a principal finalidade: a reabilitação e as obrigações funcionais. (...) Os legisladores, os psicólogos e os estudiosos da matéria há muito reconhecem a importância do meio para atingir a meta desejada, isto é, não se poderá tratar de regenerar ou educar os homens quando as próprias linhas dos estabelecimentos educacionais são os primeiros fatores a ofender esses homens (AE, junho de 1951, p. 63).

52 A relação entre arquitetura e ideologia institucional era uma preocupação constante no período. Além das penitenciárias que deveriam ser "esteticamente" humanizadas, é possível verificar essa postura em relação a outros estabelecimentos, como os asilos psiquiátricos. O processo de tombamento do Hospital do Juqueri, que tramita desde 1986, pelo Conselho de Defesa do Patrimônio Histórico, Arqueológico, Artístico e Turístico do Estado de São Paulo - CONDEPHAAT, reproduz um minucioso relatório do arquiteto Ramos de Azevedo, responsável plano arquitetônico e construção do Juqueri, no qual o autor ressaltava que "nesta construção procurei suprimir as grades de ferro das janelas, para dar às casas o aspecto de habitação comum. (...) essa pequena modificação deu às casas outro aspecto; não se lhes nota agora a feição de cadeia, feição sinistra e sempre desagradável" (RAMOS DE AZEVEDO, Apud, Secretaria de Estado da Cultura, Processo 24601/1986, p. 56). Note-se que a "feição de cadeia” é associada a algo negativo, à masmorra, imagem da qual as modernas instituições querem, a todo modo, se livrar. 
Lemos Britto, recorrentemente criticava os aspectos das penitenciárias antigas, que intimidavam tanto aqueles que estavam do lado de fora quanto os que estavam do lado de dentro. Em suas palavras "mais do que as altas muralhas, e as punições disciplinares, conserva pacíficos e submissos os sentenciados um bom regime inteligentemente aplicado por funcionários instruídos e humanos" (APB, 1942a, p. 109). O regime penitenciário humanizado, que incluía um plano arquitetônico específico, era muito mais eficaz, na visão do penitenciarista, que castigos e aspectos de masmorras. Segundo Lemos Britto:

estamos habituados a contemplar as penitenciárias circundadas de pesadíssimos e antiestéticos muros, alguns deles de mais de dez metros de altura. Tais muros visam a impedir as evasões e também que os sentenciados tenham a visão do mundo exterior, do qual se pretende que vivam inteiramente segregados. Daí a preocupação de isolar os estabelecimentos penais. O passado avança sobre o presente com o seu peso morto (...) (APB, 1942a, p. 109).

Frente a esse passado punitivo "bárbaro", que invadia o presente "moderno", deveria ocorrer a "evolução" do sistema prisional. É esse o tom que permeia as reformas prisionais do final da década de 1930 e das décadas de 1940 e 1950, e a construção dos primeiros estabelecimentos prisionais femininos no país. Espaços adequados à aplicação de penas capazes de recolocar o indivíduo na sociedade, cumprindo corretamente sua função social: esse era o ideal prisional apregoado nos discursos sobre o cárcere no período pesquisado.

Nesse cenário de reformas e inaugurações prisionais a presença e/ou as menções a autoridades políticas são marcantes. O presidente Getúlio Vargas é sempre mencionado como o grande incentivador das inovações penitenciárias e um homem visionário que colocava o Brasil em patamares de modernidade. $\mathrm{Na}$ inauguração do complexo de Bangu sua presença foi amplamente comentada, e os elogios a ele não faltaram. Apesar de tais elogios serem óbvios em um cenário de inauguração de obras públicas, Lemos Britto, em 1942, em oração proferida na ocasião da abertura da Pe- 
nitenciária de Mulheres e do Sanatório Penal para tuberculosos, ambos em Bangu, busca cuidadosamente desconstruir a obviedade, com o intuito de desarmar um futuro pesquisador ao saber que poderia vir a criticá-lo pelo excesso de homenagens ao presidente. Em suas palavras:

e se ao escrever a história destes monumentos, o escritor de amanhã encontrar nomes para citar como de devotados obreiros e colaboradores dessa nobre causa, o certo é que ninguém poderá ver nisto uma expressão protocolar ou um gesto de cortezanismo, a V. Ex. [Getúlio Vargas] cabem, a todas as luzes da verdade, as glórias deste acontecimento (APB,1942d, p. 10).

Ministros da Justiça e dos Negócios Interiores, como Francisco Luís da Silva Campos (ministro em 1932 e entre 1937 e 1942), Alexandre Marcondes Machado Filho (de 1942 a 1943 e durante o ano de 1945) Francisco Negrão de Lima (de 1951 a 1953) e Tancredo Neves (de 1953 a 1954) são também mencionados como nomes importantes nas realizações penitenciárias nacionais, estando sempre presentes nos eventos organizados pelo Conselho Penitenciário do Distrito Federal, como visitas a penitenciárias e inaugurações. Destacando especificamente a importância do ministro Francisco Campos, do presidente Getúlio Vargas e de penitenciaristas na viabilização do complexo de Bangu, Lemos Britto, na introdução ao volume dos Arquivos Penitenciários do Brasil dedicado especialmente a celebrar as inaugurações em Bangu, pontua que:

não é a história das aspirações e dos estudos feitos em torno da necessidade de dar-se alojamento condigno e educação às mulheres condenadas e às simplesmente processadas, ou tratamento especial aos sentenciados tuberculosos, o que se escreve nas páginas deste volume dos arquivos penitenciários do Brasil. Esta história virá ao seu tempo, e então quantos se empenharam na propaganda destas idéias e aspirações serão postos no devido realce, em sua auréola de precursores de uma iniciativa que afinal chegou à realidade graças à perseverança de um pugilo de penitenciaristas, à larga visão de um Ministro de Estado, 
e sobretudo a compreensão dessa necessidade que teve o Presidente Getúlio Vargas. Sua Excelência, de fato, tinha o problema penitenciário como um dos mais prementes do seu governo, e daí sua decisão de dotar a Capital Federal dos estabelecimentos penais que pudessem servir de padrão aos Estados nesta hora em que o novo Código impõe adaptações e reformas radicais (APB, 1942d, p.7)

É interessante notar que o presidente do Conselho Penitenciário atribuía tamanha importância à inauguração desses prédios, que inclusive previa que tal momento seria estudado posteriormente, como de fato está sendo feito neste e o foi em outros trabalhos.

Uma vez explicitadas as principais legislações, o momento político, os debates, reflexões e práticas penitenciárias no Brasil, bem como alguns atores que atuavam nesse cenário, faz-se necessário, para que seja possível compreender a quem o cárcere feminino era destinado, mapear os espaços sociais reservados às mulheres no período, bem como os lugares do desvio, ou seja, aqueles que não correspondiam ao “dever ser" feminino. Quais os papéis esperados das mulheres na sociedade brasileira na primeira metade do século XX e como deveriam se comportar aquelas consideradas "mulheres honestas"? Quem eram as que não se encaixavam nos perfis de mulheres ideais e qual o lugar que deveriam ocupar?

Uma das maneiras possíveis de tratar das delimitações do desvio é traçar o que é estabelecido como normal, de modo a, partindo do paradigma do correto, compreender as brechas e rotas que delineiam o incorreto. Desenhos do "dever ser" e "não ser" femininos mostram diferentes lados de um contexto social específico. Esses e outros pontos serão levantados a seguir. 


\section{Capitulo Dois}

\section{"DEVER SER" E \\ “NÃO SER" FEMININOS}

\section{O “DEVER SER"}

E como o homem comprehendeu, afinal, a necessidade de não dispensar os seus haveres, de procurar um remanso para a vida mais e mais intensa da sociedade e do trabalho, de garantir a pureza da linhagem de sua prole e de resguardar o patrimônio que lhes há de legar, deu uma base mais sólida à familia, redimindo a mulher da condição de escrava, santificando a união por concessöes e restriç̧óes reciprocas, emprestando ao amor o seu feitio mais encantador e bello. Lemos Britto, 1933, pp. 336 e 337

No início do século XX houve uma rápida mudança no cotidiano de algumas cidades brasileiras, como São Paulo, devido, principalmente, ao desenvolvimento econômico de polos da agricultura cafeeira. As elites locais passaram a investir na modernização das cidades, transformando-as em um espaço em constante movimento na tentativa de alcançar o tão procurado progresso, que deveria acompanhar a recém proclamada república. Morar nas cidades, abandonar o atrasado campo, 
educar os filhos nos padrões de uma metrópole são ações que passaram aos poucos a compor o imaginário de elites rurais que buscavam um padrão de vida semelhante ao das elites do "mundo civilizado". Mudanças significativas no modo de vida, principalmente no tangente ao "dever ser" dos atores no seio social, acompanhavam o trânsito da aristocracia rural à modernidade burguesa citadina.

Além disso, a criação de indústrias e aumento da demanda por profissionais liberais nas grandes cidades possibilitou modificações significativas desses espaços. O Rio de Janeiro, então capital do país, sofreu um crescimento populacional entre 1890 e 1940 de aproximadamente 200\%. Isso devido ao aumento do número de funcionários na administração da república e à chegada de imigrantes europeus e migrantes rurais, atraídos pelas oportunidades de empregos. Já durante o mesmo período, de 1890 a 1940, a população da cidade de São Paulo aumentou aproximadamente $2000 \%$, sendo tal crescimento ocasionado principalmente pela criação de indústrias e conseqüente alta no número de empregos, o que levou à migração do campo para a cidade atraindo inclusive imigrantes europeus e asiáticos, inicialmente destinados às fazendas de cafés3 (BESSE, 1999, pp.16 e 17).

Segundo o historiador Nicolau Sevcenko (1992), essa nova "sensibilidade urbana" das elites, que demandava um movimento rumo ao moderno, não acontecia de maneira refletida, mas representava a importação de um estilo de vida europeu burguês sem que houvesse um projeto político de ruptura com uma sociedade tradicionalista e conservadora; no cenário urbano a tradição se revestia de modernidade. A ocupação dos espaços urbanos pelas elites exigia novos padrões estéticos e higiênicos à altura das cidades européias e dos Estados Unidos, sendo necessárias reformas e adaptações.

No entanto, as modificações urbanas ocorridas nas primeiras décadas do século XX, como aquela comandada por Antônio Prado em 1910, na cidade de São Paulo, representaram mais um processo de embelezamento que de modernização efetiva da cidade (SEVCENKO, 1992, pp. 45 a 51). Embelezar e limpar a

53 A população de São Paulo aumentou de 64.934 habitantes em 1890 para 1.326 .261 em 1940. 
cidade para que correspondesse aos anseios de seus mais ilustres moradores era a tarefa principal a ser seguida pelos responsáveis pelas reformas. Era no investimento em beleza, na higienização, na ordem e na disciplinarização para o convívio na "nova cidade "que o imaginário moderno buscou introduzir disciplina e normalização no seio social.

O rápido processo de urbanização pelo qual passaram cidades como Rio de Janeiro e São Paulo alterou, em parte, as tradicionais estruturas patriarcais edificadas desde o Brasil colônia nos meios rurais. O patriarca, que tinha poderes quase absolutos em relação aos destinos de seus filhos, empregados, esposa e concubinas, passou a perder espaço para o modelo burguês de família seguido pelas classes médias e altas nas cidades. Nesse contexto, surgiram, aos poucos, novas dinâmicas em relação à profissão e casamento dos filhos e filhas, aos espaços ocupados pelas mulheres na casa e ao próprio papel da família que, paulatinamente, era remodelada. Segundo Susan Besse, historiadora que pesquisou o que chama de "reestruturação da ideologia de gênero" ocorrida no Brasil no início do século XX,

em meados de 1910, dezenas de anos de desgaste do poder patriarcal já haviam tornado obsoletas a organização tradicional da família da elite e as definições de gênero. Como instituições extrafamiliares haviam assumido muitas das funções da família patriarcal extensa, esta foi sendo gradualmente substituída pelo modelo de família nuclear burguesa urbana (BESSE, 1999, p. 19)

No tangente à elite, as mudanças vieram tanto em relação ao destino dos filhos dos fazendeiros, que, com a mudança para as cidades puderam cursar universidades (tanto no Brasil quanto fora), seguir carreiras públicas, ou se tornar profissionais liberais, livrando-se do destino de cuidar das propriedades rurais dos pais; quanto ao das filhas que passaram a freqüentar as ruas da cidade, ter acesso à educação e certa flexibilidade na escolha do futuro esposo. De acordo com as historiadoras Marina Maluf e Maria Lúcia Mott, 
era nas cidades, as quais trocavam sua aparência paroquial por uma atmosfera cosmopolita e metropolitana, que se desenrolavam as mudanças mais visíveis. (...) A nova paisagem urbana, embora ainda guardasse muito da tradição, era povoada por uma população nova e heterogênea, composta de imigrantes, de egressos da escravidão e de representantes da elite que se mudavam do campo para as cidades (MALUF e MOTT, 2008, p. 371).

Ainda, de acordo com Besse, a vida na cidade "aumentou drasticamente as oportunidades de investimento, emprego, mobilidade social e mobilização política - oportunidades que, por sua vez, fomentaram transformações na consciência e, gradativamente afrouxaram as relações patriarcais tradicionais" (1999, p.18). Na cidade em crescimento, mulheres de diferentes classes sociais passaram a ocupar partes do espaço público, até então predominantemente masculino. No centro das grandes cidades, mulheres transitavam nas ruas, flanando em passos lentos para compras e passeios - no caso das mulheres das elites - e apressadas para seus trabalhos nas fábricas - para as operárias (SEVCENKO, 1992, pp. 50 e 51). As novas rotinas femininas na urbe - que incluía o trânsito de mulheres nas ruas, a frequência em espaços coletivos - e dentro de casa - na relação com os pais e maridos - eram motivos de críticas e questionamentos de uma maioria conservadora que temia a desordem social e a quebra dos valores morais vigentes.

Um exemplo desses movimentos de avanço feminino no espaço urbano e desconcerto dos pensadores do período é o do conflito que a presença feminina nos espaços públicos gerava: ao mesmo tempo em que era exigido da mulher um refinamento, um cuidado estético consigo e com os filhos e uma imagem impecável, digna de ser exposta na cidade, a futilidade feminina era algo que deveria ser combatido. A mulher não podia se render aos excessos nas compras, ao culto a si mesma e ao consumo. $\mathrm{O}$ transitar feminino pela esfera pública, ao mesmo tempo em que exigia uma mulher bem apessoada e cuidada, poderia provocar a futilidade. Segundo a historiadora Margareth Rago: 
(...) se todas as transformações na vida urbana incitavam a uma maior visibilidade da mulher na esfera pública, o preço que pagava era o de enorme vigilância sobre seus mínimos gestos e a elaboração de uma nova imagem que associava à mulher ociosa e passiva do passado a figura da jovem sem nenhuma densidade, preocupada apenas com frivolidades (RAGO, 2008, p. 73).

Com o crescimento vertiginoso da mão de obra feminina nos trabalhos fabris - uma vez que, no início do período de industrialização, mulheres representavam grande parte do contingente operário da produção têxtil - e o aumento do número de mulheres em profissões liberais, o trabalho feminino fora de casa passou a ser debatido, nas primeiras décadas do século XX, juntamente com temas relacionados à sexualidade. Sair do ambiente doméstico poderia significar falar de tabus relacionados ao adultério, à virgindade, à prostituição e ao casamento, e questionar instituições sólidas como a família. Assim, o fato de as mulheres passarem a ocupar o cenário urbano, seja para o trabalho, seja para o lazer, não significa que as exigências sociais sobre elas afrouxaram e que os "olhares" da sociedade citadina seriam mais brandos que os do patriarca. De acordo com Rago,

(...) quanto mais ela escapa da esfera privada da vida doméstica, tanto mais a sociedade burguesa lança sobre seus ombros o anátema do pecado, o sentimento de culpa diante do abandono do lar, dos filhos carentes, do marido extenuado pelas longas horas de trabalho (RAGO, 1997a, p. 63).

O combate ao trabalho fabril feminino, no início do século XX, veio de diferentes frentes - como de médicos, juristas, políticos, operários - e por razões diversas. $\mathrm{O}$ discurso afinado de que o lugar do sexo frágil era dentro de casa, encobria interesses de reserva de mercado para homens, preservação da família, controle das camadas populares e garantia de prole sadia. Segundo Rago

muitos acreditavam, ao lado dos teóricos e economistas ingleses e franceses, que o trabalho da mulher fora de casa destruiria a família, tornaria os laços familiares mais frouxos 
e debilitaria a raça, pois as crianças cresceriam mais soltas, sem a constante vigilância das mães (RAGO, 1997b, p. 585).

Tanto Maluf e Mott (2008, pp. 371 e 372), quanto Besse (1999, pp. 63 a 65) ressaltam que houve um esforço de intelectuais e pessoas influentes da época no sentido de conter os efeitos nefastos que esta aparente modernização do papel social de mulheres poderia gerar. A valorização da família se dava no sentido de garantir a perpetuação de estruturas fundamentais à edificação de uma nação sadia e moderna, dentro dos valores de uma moral cristã e atenta às demandas de progresso. Nesse sentido, o casamento era a instituição que, por excelência, garantiria a formação da família, considerada a maior representação do Estado no âmbito privado (BESSE, 1999, p. 69 e p. 88). Investir no casamento significava auxiliar a construir o modelo ideal da família brasileira, estimular o nascimento de filhos sadios que seriam o "futuro da nação".

Nesse sentido, vale mencionar o papel da Eugenia - movimento científico que aportou em terras latino americanas no início do século XX com o objetivo de refletir sobre as formações raciais nacionais, e estimular uma identidade racial homogênea e civilizada na estruturação da família brasileira. Segundo a historiadora Nancy Stepan, houve na América Latina, a partir de meados dos anos 1920, o investimento em uma "eugenia matrimonial", de modo a estimular que apenas casais saudáveis, sem caracteres hereditários anômalos, pudessem ter filhos (STEPAN, 2005, pp. 115 a 141). Era uma forma peculiar de eugenia reprodutiva, uma vez que no Brasil e em outros países latino americanos o aborto e a esterilização eram práticas altamente recriminadas pela Igreja Católica. Assim, para garantir uma nação sadia, os casamentos deveriam se dar entre pessoas sadias, e para isso era necessário que os nubentes fizessem exames pré-nupciais "como forma de incentivar a formação de grandes e saudáveis famílias" (STEPAN, 2005, p. 133). A introdução de uma "cláusula nubente" na Constituição Federal de 1934, que "exigia que os casais que pretendiam contrair matrimônio apresentassem prova de sua saúde física e mental antes do casamento (...)", comprova a preocupação dos legisladores com a saúde hereditária da 
nação (STEPAN, 2005, p. 135). A eugenia seria uma forma de "cuidar da raça” eliminando a degeneração da sociedade brasileira (SCHWARCZ, 2008, p. 216).

Besse chama a atenção para o fato de que, dentre as classes mais pobres, o casamento legítimo fazia, igualmente, parte do plano da elite de ordenar a vida na cidade. Para as elites, as famílias da classe operária, constituídas de maneira legal, por meio do casamento, eram fundamentais para "por fim à militância da classe operária, garantir a permanência da dominação masculina (e, por extensão, a hierarquia social de que elas se beneficiavam) e assegurar o desenvolvimento físico e moral das crianças que iriam se tornar futuros operários” (BESSE, 1999, p. 64). À época, poucos eram os casamentos legais entre as classes mais baixas, sendo a organização familiar menos institucionalizada e, portanto, menos sujeita ao controle estatal.

A família nuclear, sadia, limpa, educada e feliz deveria ser o principal desejo dos trabalhadores, e prover a essa família o conforto e os bens necessários para a sua estruturação deveria ser a meta desses operários. Nesse sentido, Rago pontua que “(...) a domesticação do novo operariado implicou a imposição do modelo imaginário de família criado pela sociedade burguesa” (RAGO, 1997, p. 61). O Estado incentivava que o estilo de vida inacessível da família burguesa fosse perseguido, ainda que com pretensões mais modestas, pois isso garantiria o controle de homens e mulheres que, a partir do momento em que tivessem família, passariam a "ter algo a perder”. O psicanalista Jurandir Freire Costa, em seu estudo sobre ordem médica e norma familiar no início do século XX no Brasil, evidencia que o papel do homem no modelo higiênico de família, estimulado nas cidades em crescimento, seria pautado com base nos filhos:

vai casar para ter filhos; trabalhar para manter os filhos; ser honesto para dar bons exemplos aos filhos, investir na saúde e educação dos filhos; poupar pelo futuro dos filhos; submeter-se a todo tipo de opressão pelo amor dos filhos; enfim, ser acusado e aceitar a acusação, ser culpabilizado e aceitar a culpa, por todo tipo de mal físico, moral ou emocional que ocorresse aos filhos (COSTA, 1999, p. 251) 
Autoras que pesquisam o momento histórico em questão, como Besse (1999) e Maluf e Mott (2008), acentuam como o Código Civil de 1916 reforçava uma divisão sexual do trabalho enfatizando a supremacia do homem como chefe da família, provedor, e a subordinação feminina em relação ao marido. $\mathrm{O}$ esposo tinha como função central prover a manutenção da família, por meio do trabalho honesto e remunerado, enquanto a esposa deveria assumir uma identidade social de mãe, esposa e dona de casa. Além disso, segundo esse diploma legal, a mulher casada necessitava da autorização do marido para trabalhar fora de casa (BESSE, 1999, p. 88). Na década de 1930 algumas medidas em prol da família legalmente constituída fizeram parte da agenda legislativa nacional, o que pode ser visualizado, por exemplo, na Constituição Federal de 1934, que previa cota orçamentária para a promoção da saúde de mães e filhos; na Constituição de 1937, que colocava o cuidado com a família como uma das prioridades do Estado; bem como na criação da Comissão Nacional para a Proteção da Família, em 1939. Foi justamente essa Comissão que criou leis tornando o casamento gratuito, incentivando a maternidade, facilitando a compra de casas próprias e regulamentando a educação infantil (BESSE, 1999, p. 77).

Essa estrutura familiar estimulada pelo Estado previa arranjos específicos de papéis desempenhados por homens e mulheres, fundamentais para a manutenção das expectativas em relação aos sexos e, consequentemente para o controle da população. Enquanto o homem, saudável e forte, deveria trabalhar para sustentar a família, a mulher, frágil e doce, deveria cuidar dos filhos, do lar e do marido. Os rígidos papéis sociais redesenhados no início do século XX serviram para engessar homens e mulheres em locais sociais específicos, bem como para ditar regras de condutas estabelecendo um rigoroso "dever ser" de cada sexo. Maridos e mulheres deveriam exercer papéis complementares e bem definidos. Nesse sentido, segundo Maluf e Mott:

'a mulher, que é, em tudo, o contrário do homem’ foi o bordão que sintetizou o pensamento de uma época intranqüila e por isso ágil na construção e difusão das representações do comportamento feminino ideal, que limitaram seu horizonte ao 'recôndito do 
lar' e reduziram ao máximo suas atividades e aspirações até encaixá-la no papel de 'rainha do lar', sustentada pelo tripé mãe-esposa-dona de casa (MALUF e MOTT, 2008, p. 373).

O modelo ideal de casamento, que vinha sofrendo alterações desde meados do século XIX, teve seu apogeu com o crescimento das cidades. De acordo com Jurandir Freire Costa, a partir do século XIX, o casamento aos poucos passou a ser visto como instituição higiênica, capaz de gerar filhos sadios para a construção de uma nação sadia. A hereditariedade tornou-se mais importante que a herança quando em pauta estava o futuro da nação e sua inserção no mundo moderno (COSTA, 1983, pp. 219 a 226). O modelo da família burguesa era oficialmente incentivado pelas autoridades e especialistas, sendo considerado padrão de normalidade universalmente aceito nas sociedades civilizadas. No entanto, esse modelo de família conjugal, não foi facilmente aceito ou mesmo adotado pelas camadas populares. A história da família no Brasil, como bem aponta a antropóloga Cláudia Fonseca, é a história das famílias, e de inúmeros modelos de redes de parentesco, que não podem ser reduzidos unicamente à nuclear. (FONSECA, 1997, p. 513 e 522). Entre o esperado e o praticado havia uma gama de possibilidades e realidades que superava a imaginação de doutrinadores e especialistas do período.

No interior da família nuclear, monogâmica, heterossexual e sadia, preconizada nos moldes do ideal burguês, agia o Estado por meio, principalmente, do Direito e da Medicina. A família que interessava ao Estado era aquela sadia em termos médicos e psíquicos, com papéis bem definidos para maridos e mulheres, com filhos bem criados, e regulamentada nos termos da lei. Costa ressalta a função do "amor" na estruturação desse modelo de família:

no casamento produtivo, as diferenças harmonizavam-se porque homens e mulheres perseguiam um ideal superior, capaz de uni-los não obstante as divergências. Mais que isto, este ideal precisava justamente desta diversidade para ser levado a termo. A educação dos filhos começou, desta forma, a surgir como uma nova maneira de amar. O cuidado das crianças não era mais uma obrigação, mas um ato espontâneo de amor. Amor paterno e 
amor materno eram o denominador comum entre homens e mulheres. Só este modo de amar conciliava o inconciliável (COSTA, 1999, p. 238).

Os papeis desempenhados pelos diferentes sexos no casamento eram preestabelecidos em um contexto social no qual, em sua maioria, homens freqüentavam o espaço público, enquanto às mulheres eram reservados os afazeres do mundo doméstico, espaço principal da família. A maternidade, nesse contexto, surgia como um dom das mulheres oriundo da relação íntima com os filhos propiciada pela gestação. Enquanto a mulher nascera para a família e para a maternidade, o homem moderno deveria se realizar igualmente no casamento, na paternidade e no trabalho. Ambos eram provedores em diferentes sentidos, complementando-se na criação dos filhos e manutenção da família e do lar. De acordo com Costa "esta identificação entre masculinidade e paternidade e feminilidade e maternidade será padrão regulador da existência social e emocional de homens e mulheres" (COSTA, 1999, p. 239).

Majoritariamente o mundo do trabalho era masculino e representava o espaço do público, alheio ao universo privado das mulheres. Nas palavras de Rago "enquanto o mundo do trabalho era representado pela metáfora do cabaré, o lar era representado como o ninho sagrado que abrigava a 'rainha do lar' e o 'reizinho da família”" (RAGO, 1997 a, p. 588). Um moralismo crescente passou a fazer parte do pensamento acerca da mulher trabalhadora - fosse profissional liberal ou operária -, sendo constante o temor de que o trabalho feminino levasse à desagregação da família.

O trabalho feminino fora do âmbito doméstico era estimulado apenas para complementar a renda da família, quando necessário, assim como em casos de utilidade social, para a realização de tarefas tipicamente femininas, como a enfermagem, o magistério, os trabalhos domésticos. Em geral às mulheres eram reservados trabalhos nas fábricas, como secretárias em escritórios, atendentes em lojas, professoras primárias, floristas, bordadeiras e costureiras, domésticas, lavadeiras e telefonistas (BESSE, 1999, p. 147; LOURO, 1997, p. 454; RAGO, 1997a, p. 63; SOIHET, 1997, p. 365). 
A antropóloga Olívia Maria Gomes da Cunha, ao analisar o conceito de domesticidade e a relação entre as criadas de servir seus patrões e patroas, chama a atenção para as diferentes composições do trabalho feminino no ambiente doméstico. A função de mãe e dona da casa diferia da função de criada e empregada - diversos tipos de domesticidade no território da casa. Enquanto as mulheres de classe alta deveriam ser mães e educadoras, as criadas cuidavam dos trabalhos domésticos como lavar, passar, cozinhar e servir. A autora relativiza a rígida separação entre público e privado, ao mostrar que as fronteiras entre a casa e a rua eram menos rígidas que a dicotomia pressupóe, uma vez que o lar representava um importante espaço social no processo civilizatório e modernizador, sendo “(...) cada vez mais visto como uma esfera de relações cujo controle e o poder são, não mais naturalmente, mas socialmente desempenhados" (CUNHA, 2007, p. 395).

Cláudia Fonseca, por sua vez, destaca a necessidade da mulher pobre de trabalhar e auxiliar ou mesmo de ser a protagonista no sustento da casa, o que a colocava no difícil dilema de romper com o papel social a ela estipulado e enfrentar o mundo público, organizado pelos e para os homens. Segundo a autora, a mulher pobre sempre trabalhou no Brasil e essa era uma realidade que não se encaixava no modelo estabelecido de homem provedor e mulher submissa que o padrão da família nuclear preconizava, o que, no dia a dia, gerava inúmeros conflitos. (FONSECA, 1997, pp. 516 e 517; SOIHET, 1997, p. 379). Muitas das vezes a culpa por não corresponder ao ideal esperado recaia na mulher, que deveria arcar com a fama e o ônus de romper com o padrão estabelecido como normal.

Já estudar era prática incentivada para mulheres, mas com o cuidado de que não se desviassem do lugar social a elas destinado. Assim, disciplinas como economia doméstica, puericultura e higiene escolar passaram a fazer parte da grade das escolas normais, que visavam a formar educadoras e mulheres preparadas para as tarefas do lar (LOURO, 1997, pp. 457 e 458). As escolas eram espaços disciplinadores, que deveriam inculcar nas alunas a moral da vida conjugal, da maternidade e do cuidado para com o outro.

É ilustrativo dessas concepções o estudo do médico eugenista Júlio Afrâ- 
nio Peixoto ${ }^{54}$, em seu estudo denominado $A$ Educação da Mulher, de 1936, no qual ressaltava a importância de ensinar educação sexual nas escolas, de modo a garantir que meninos e meninas conhecessem de maneira científica as verdades da reprodução, e não ficassem na completa ignorância sobre o assunto. Com a educação sexual, as mulheres conheceriam melhor o seu corpo e entenderiam os processos orgânicos que nele aconteciam, como a menstruação e a gravidez. Tais ensinamentos eram fundamentais para uma vida reprodutiva sadia, bem como para garantir que os casamentos não se fundassem na ignorância completa dos deveres nupciais.

O ensino da puericultura, ou seja, "a arte de zelar as crianças" seria voltado para as meninas "desde a escola primária, de preferencia à escola normal, pois é na infância que as meninas mais se interessam pelas bonecas e, aprendendo a tratá-las, aprenderão do mesmo modo a cuidar das bonecas vivas, de amanhã" (PEIXOTO, 1936, p. 189). De modo a estimular que a prole fosse bem cuidada e bem educada, a puericultura passou a ser moda entre as mulheres na primeira metade do século XX, higienizando a relação mãe-filhos. Segundo Peixoto:

a educação começa no berço, se diz, á saciedade. Começa de antes. Uma mãi, não educada sexualmente, higienicamente, porá em perigo a vida de sua criatura, senão a própria vida... A educação é uma longa sequencia de actos e habitos, ordenados e uteis. A mãi educada começou a educar a sua derivação, o filho, que cria sadiamente nas suas entranhas e criará sadiamente vindo á luz: tudo isto é educação (PEIXOTO, 1936, p. 189).

Inclusive penitenciaristas, como Lemos Britto, em 1933, reafirmavam esses padrões ao alertar para o fato de que a educação feminina deveria ser realista, de modo a não formar pessoas destacadas da realidade cotidiana da vida em família. Não bastava o casamento para que houvesse a garantia de uma "vida harmôni-

54 Escritor, médico e educador que, durante a primeira metade do século XX, escreveu inúmeras obras sobre educação, higiene, medicina e literatura. Foi um ativo representante do movimento higienista. Sobre sua biografia, ver CÓSER, Silvana; MOTA, Joaquim e LOPES, Eliane, 1994. 
ca”, mas era necessário conhecer os percalços de modo a não se desiludir com ele. $\mathrm{O}$ despreparo para a realidade do matrimônio e com a vida a dois poderia gerar o desgaste e a infidelidade. De acordo com o jurista:

(...) a mulher carece de uma educação mais pratica, mais positiva, menos hypocrita, que a torne menos piegas, menos sonhadora e romântica, de modo a não ter tão funda desillusão no casamento (...). No lar, aprende a moça a esperar um marido ideal, que seja como os príncipes encantados, que lhe reserve uma existência de beijos e caricias, vivida em vilinos deliciosos, ou em retiros floridos, sem dissabores, sem difficuldades, sem enfartamentos, ignorando, portanto, que, ao menos para o homem, a posse traz o tédio desde quando o outro conjuge não saiba atrahil-o e captival-o sempre, renovando-se, impondo-se por esses mil meios de que a mulher intelligente e educada sabe lançar mão para prender o marido (LEMOS BRITTO, 1933, pp. 201 e 202).

Para Lemos Britto, um lar sadio, bem organizado, erguido sobre preceitos morais e éticos, no qual prevalecesse a harmonia, era fundamental para a manutenção da família, núcleo social principal na sociedade que se firmava. Uma solução plausível para romper com uma possível situação de submissão à qual a mulher estava sujeita na relação conjugal, seria o trabalho fora de casa, que garantiria a ela certa independência e satisfação na vida a dois. Em suas palavras:

se o casamento é hoje uma organisação economica, e a mulher se sente opprimida pela autoridade marital, procure ter uma relativa independencia, trabalhar, ganhar, constituir-se um elemento de acção, e dessa independencia economica resultará a outra - dentro do lar (LEMOS BRITTO, 1933, pp.202 e 203).

Vinte anos depois de Lemos Britto, em 1953, advertia a assistente da cadeira de Introdução à Criminologia da Escola de Polícia, Hilda Macedo, para quem os deveres da esposa deveriam ser ensinados em "escolas de noivas", garantindo que as recém casadas e recém mães soubessem como se portar para que fossem reproduto- 
ras de famílias bem estruturadas, éticas e herdeiras de uma boa moral e bons costumes. Em suas palavras:

bem hajam as escolas de noivas que já existem entre nós. Que elas frutifiquem, que ampliem seus programas, impedindo que se encaminhem para o casamento moças ignorantes dos deveres de esposa e mãe. Esposas e mães conscientes, moral e fisicamente sadias, hão de fazer de seus filhos seres conscientes, morais e sadios (MACEDO, 1953, p. 288).

Além do trabalho de educação formal, em espaços específicos, como as escolas e os cursos livres, a educação para o lar, de acordo com Lemos Britto, quando transmitida dentro de casa, por meio de bons exemplos familiares, era extremamente eficaz para gerar filhas fieis e bem casadas. Lições de comportamento e moral seriam transmitidas pelas famílias, de modo a reproduzir bons modelos de "mulheres honestas" e "moças de família”. Nas palavras de Lemos Britto:

(...) o ambiente domestico influe poderosamente na mulher. São raros os casos de infidelidade nas familias desenvolvidas á sombra da moral domestica sem falhas. As familias que se fizeram depositárias de grandes virtudes transmittem-n’as de paes a filhos, através de uma tradição rica em lições e fecunda em bons exemplos. Nada prepara melhor o caracter da mulher que essa respeitabilidade tradicional dos lares antigos, perpetuada através de gerações que lhe copiam os hábitos (LEMOS BRITTO, 1933, pp.177 e 178).

No entanto, Lemos Britto, em oração proferida na solenidade de entrega do diploma às alunas que terminaram o curso técnico de Serviço Social, em dezembro de 1941, salienta a ideia de que não era interessante mulheres "presas em casa” sendo mimadas e cuidadas. Estimulava que, assumindo suas posições de mulheres, trabalhassem, fizessem trabalhos de caridade, exercessem funções femininas, praticassem economia doméstica, complementassem com afazeres femininos a renda da casa. Nesse sentido o autor ressalta que: 
não foram as tendências e hábitos femininos que se modificaram em sua essência; o que distingue a mulher moderna da antiga é apenas a coincidência do seu valor e a coragem de suas atitudes. Não me fareis a injustiça de acreditar que incluo nessa coorte lúcida e intrépida aquelas mulheres que, como flores de estufa se estiolam na ociosidade e nos prazeres, vítimas de um caricato egocentrismo, morbidamente convencidas de que o mundo gira em torno de suas pessoas e de que nenhum dever de cooperação e solidariedade lhes assiste. São elas exceções que desprezamos como elemento infinitesimal das componentes de força da civilização (APB, 1942b, p. 358)

Lemos Britto era um homem de seu tempo que via a mulher com atributos naturais, que deveriam ser aproveitados pelos espaços sociais. Era a favor da presença da mulher no mundo do trabalho, especialmente exercendo funções que utilizassem as suas atribuições naturais de paciência, cuidado, educação, dentre outros. No mesmo discurso pronunciado na formatura de assistentes sociais o jurista dizia que:

nem pode o homem desempenhar esse papel à cabeceira dos enfermos, no interior dos seus lares, na catequese dos inadaptados. Falta-lhes a doçura, o espírito de acomodação do ambiente saturado de dor ou desespero, que caracteriza o elemento feminino. Cada qual tem o seu papel marcado nessa atividade. O dela é diferente. Mais sentimental. Mais afetivo. Mais cheio de condescendência e compassividade. Não pode haver povo feliz sem lar organizado (...). Ai está o campo naturalmente aberto ao exercício das faculdades femininas (APB, 1942b, p. 360).

Em relação a esse mesmo contexto, contemporaneamente, Besse avalia que as mulheres eram incentivadas a praticar a economia doméstica - bordar, costurar, plantar, cozinhar - para economizar. Os altos custos de vida na cidade obrigavam-as a fazer economia e não gastar de maneira perdulária o dinheiro que o marido ganhava. Algumas, além da costura, dos bordados e da produção de doces e plantio de verduras para consumo interno, faziam artesanato para vender (BESSE, 1999, pp. 86 e 87). A complementação da renda familiar pelo trabalho feminino era bem vin- 
da, principalmente quando não desviava a mulher de suas funções principais no lar, e era prolongamento dos trabalhos que já realizavam cotidianamente.

A valorização da maternidade como maior missão da mulher representava uma forma de resguardá-la no ambiente doméstico, contribuindo para o estabelecimento de rígidas fronteiras entre a casa e a rua, ou seja, entre o privado e o público. A mulher-mãe, santificada e pura, deveria doar-se ao lar e à prole com um amor incomensurável. Besse sublinha o uso de metáforas religiosas para designar essa mulher-mãe e a vida em família. Em suas palavras: “'os dez mandamentos das esposas transmitiam às mulheres a mensagem de que ser negligente quanto a seus deveres familiares era não só socialmente condenável, mas também pecaminoso" (BESSE, 1999, p. 79). A associação entre a mãe doadora e Maria, mãe de Jesus; a dedicação ao lar e a santidade; o lar e o sagrado; a negligência e o pecado, apareciam a todo momento nos discursos das autoridades, dos especialistas e de todos aqueles preocupados com a reprodução da família brasileira.

O discurso de valorização da maternidade rapidamente se alastrou nas diferentes camadas políticas e sociais - comunistas, anarquistas, liberais, positivistas, profissionais liberais, operários e industriais reafirmavam-no em suas práticas cotidianas (RAGO, 1997 a, p. 592). A presença das mulheres nas fábricas e no mercado de trabalho em geral representava uma concorrência em relação aos homens, já que estas recebiam salários menores e custavam menos para o empregador. Para conter a concorrência, várias foram as regulamentações sobre o trabalho feminino, como a proibição do trabalho noturno para mulheres, bem como de funções que exigissem esforço físico exacerbado.

Ser mãe era encarado como uma missão natural e divina das mulheres. O dom da maternidade deveria ser exercido por todas aquelas que fossem casadas, de modo a completar a família e gerar filhos naturais e legítimos. Casais saudáveis deveriam se reproduzir, para criar crianças sadias e sãs. $\mathrm{O}$ exercício da maternidade valorizava as mulheres, que cumpriam o mais nobre e precioso trabalho a elas destinado. Era a possibilidade de ser mãe que explicava a "naturalidade" dos sentimentos tipicamente femininos de cuidado e paciência, sentimentos tais que reforçavam 
o papel social das mulheres de cuidado com o lar, tolerância e compaixão para com os outros (BESSE, 1999, p. 101; RAGO, 1997, p. 75). A mulher, nesse cenário, foi, segundo Costa, "colonizada" por um discurso médico que exigia um cuidado de si que significava o cuidado da prole. A gestação, ocorrendo no corpo feminino, assim como o aleitamento, vinculava biologicamente a mulher ao filho, obrigando-a a ser saudável, para garantir a saúde dos descendentes (COSTA, 1999, pp. 256 a 264). Nas palavras de Fonseca:

a receita para a mulher ideal envolvia uma mistura de imagens: a mãe piedosa da Igreja, a mãe educadora do Estado positivista, a esposa companheira do aparato médico-higienista. Mas todas elas convergiam para a pureza sexual - virgindade da moça, castidade da mulher. Para a mulher ser 'honesta', devia se casar, não havia outra alternativa. E para casar, era teoricamente preciso ser virgem (FONSECA, 1997, p. 528).

Para garantir o nascimento de filhos sadios, era preciso garantir a saúde das mulheres, o que se dava tanto por meio da medicalização do corpo feminino, quanto pela regulamentação de sua sexualidade, já que doenças venéreas como sífilis comprometiam a saúde dos bebês.

Lemos Britto, em 1933, defendia a punição do adultério na esfera civil, e não criminal, uma vez que o casamento era uma instituição regulamentada pelo Direito Civil, e era nesse âmbito que deveria ser solucionado qualquer atentado contra ele. Para o autor, a solução contra o adultério estaria antes e principalmente em uma política eugenista, que em uma sanção penal. Casamentos entre sadios gerariam relações sadias, livres do fantasma da traição. Em suas palavras:

uma legislação que procure corrigir o adultério deve começar pelo exame pre-nupcial, pela prohibição de casar imposta a individuos atacados não só de enfermidades como a syphilis e a tuberculose, mas de nevropathias e psychopathias, ou que sejam sob qualquer aspecto incapazes para o casamento (LEMOS BRITTO, 1933, p. XXIII). 
O casamento monogâmico representava o espaço principal do sexo aceito, sendo, além de um local de combinação entre pudor e prazer, aquele, por excelência, da procriação. A noção de sexualidade respeitada para a mulher está intimamente ligada ao casamento, ou a relacionamentos estáveis. O espaço do casamento monogâmico e heterossexual é um espaço privilegiado de intervenção para a garantia da sobrevivência da espécie, para o "sexo seguro" e higiênico. Regulamentações da ordem da sexualidade se combinavam com normas disciplinares da conjugalidade, sendo o lar conjugal um ambiente saturado de regras e obrigações sociais, menos codificadas que socialmente introjetadas.

Assim, exigências voltadas à esposa-mãe-mulher-dona de casa eram por vezes contraditórias, sendo impossível a uma mulher conseguir conciliá-las sem contradições insuperáveis. Besse, ao analisar a posição social das mulheres em meados do século $\mathrm{XX}$, ressaltava que elas deveriam ser recatadas para a sociedade e ao mesmo tempo atraentes para os maridos; inocentes e espertas; frágeis e autoconfiantes; submissas e fortes (BESSE, 1999, p. 87). A impossibilidade de representar todos esses papéis recaía nas mulheres como incompetência e inabilidade. Ser boa esposa significava ser dedicada à casa, aos filhos e ao marido, sem exigir deste a participação nos trabalhos domésticos (MALUF e MOTT, 2008, p. 419).

Tais exigências sobre a esposa são claramente identificadas na reflexão de Lemos Britto sobre a importância da honra feminina e da manutenção desta dentro e fora de casa. A estima da honra como mantenedora da estrutura social primordial, a família, era central. Em suas palavras:

a mulher não tem somente o dever de ser honesta e fiel; cabe-lhe o dever de não permitir que esses postos sejam colocados em dúvida: se o forem estará abalada a paz doméstica e sacrificada a família no seu futuro. A murmuração social tem sido sempre causa de innumeras desgraças; cumpre, pois, à mulher, dentro do tecido social de que constitue uma das malhas, defender contra ella sua reputação (LEMOS BRITTO, 1933, p. 102). 
Adjetivos como paciente, amável, carinhosa, doce, benévola, complacente, foram vinculados à mulher como sendo características femininas naturais. A naturalização de comportamentos socialmente prescritos servia, além de outros, para identificar as mulheres consideradas desviantes, uma vez que não nasceram com tais qualidades. As mulheres que não cumpriam o esperado papel de mãe, esposa e dona-de-casa eram consideradas transviadas e a elas eram atribuídos estereótipos e classificações no plano dos desvios. "Não-lugares" de mulheres eram ocupados pelas prostitutas, lésbicas e por aquelas que não tinham profissões definidas - que viviam de "biscates" - sendo a socialização dos papéis sexuais definidora dos espaços que cada sexo poderia e deveria ocupar.

Vale salientar a análise de Lemos Britto, feita em 1933, sobre o lugar social ocupado pela mulher no período. $\mathrm{O}$ autor trata a mulher como um ser social moldado no interior de uma lógica do cuidado e da resignação. É em oposição a essa expectativa social da mulher que a prostituta é colocada, ou seja, ela é a negação do "dever ser" mulher. Características como recato, domesticidade, inocência e benevolência compõem a honra, qualidade que só pode acompanhar aquelas que estão em consonância com a expectativa social. Já a prostituta, por ser o oposto, não corresponde ao esperado e mesmo quando passa a fazê-lo, já possui um estigma social do qual não conseguirá se livrar. Lemos Britto pontua que:

a mulher é uma resultante não só da tradição doméstica, mas ainda daquelle egoísmo que a faz heróica, até o sacrifício, nos freios que põe aos seus instinctos e paixões naturaes. Desse amalgma, porém, resulta uma alma nova, transparente, vazada nos moldes clássicos da nobreza e da virtude. Nós nos habituamos a ver a mulher atravez desse fino cristal do seu recato, e por isso consideramos as prostitutas uma classe de gente que tem por dever viver nos escaninhos e desvãos da sociedade, quasi sem prerrogativas humanas. Se a mulher doméstica tivesse o direito de traçar e estatuir uma ethica para seu uso e conforme suas próprias tendências naturaes, não haveria porque relegar a esse subterraneo social aquellas que constituem, afinal, como escreveu Cezare Lombroso, a mais lógica resultante do celibato dos homens. Mas emquanto a sociedade exalta a mulher, que se torna, 
em verdade, a dona da nossa intimidade e o guia subtil dos nossos propósitos, rabaixa a prostituta de tal sorte que, se ella casou, e casada claudicou, a lei não vê nisto a figura do adulterio, porque adulterio pressuppõe honra domestica, e não tendo honra a mulher que já foi publica, o só facto do casamento não lhe adjudica essa qualidade intrinseca da alma feminina, de que despojára (LEMOS BRITTO, 1933, p. 166 e 167)

$\mathrm{O}$ jurista pontuava ainda, quais eram os principais males que ameaçavam a família e os lares honrados, ressaltando, porém, que bastava uma nação sadia e cautelosa para não se deixar levar por eles. Suas palavras são expressão de um analista que, ao mesmo tempo em que se mostrava preocupado com as mazelas da modernidade, entendia sua inexorabilidade e buscava formas de prevenir que estas afetassem a principal base social que era a família. Para ele:

o urbanismo, ou a emigração das populações ruraes para as cidades, o suicídio, o luxo, o aborto criminoso, o infanticídio, os processos malthusianos, o adultério, o amor livre... Não exageremos sua influência, por enquanto, no robusto organismo da nossa pátria; não permittamos, porém, que pelo receio de parecermos fúteis em contraste com a dissolução assoberbante dos costumes, esses males tomem um vulto inesperado, assumam, de chofre, a extensão de uma epidemia e acabem por dissolver, no seu desfarçamento, o caráter de aço e a rija organização dos lares (...) (LEMOS BRITTO, 1933, pp. 11 e 12).

$\mathrm{Na}$ cidade em crescimento, os lugares do correto também serviam para pontuar os lugares do desvio, e vice versa. Ao modelo da mulher ideal, se contrapunham modelos outros, que não se encaixavam nos anseios oficiais e sociais; ao modelo aceito de casamento inúmeras outras formas de família e conjugalidades eram contrapostas; à mãe protetora e presente, se opunha a mãe solteira, a mulher que abortava ou a que decidia não ter filhos. Quem eram e onde estavam, no mapa da cidade, aquelas que compunham as rotas dos desvios são questões que serão levantadas no próximo tópico. 


\section{DESVIOS}

$\mathrm{Na}$ contra-mão do "dever ser" estavam aquelas mulheres que desfaziam os arranjos esperados de esposas devotadas, boas mães e bons exemplos sociais: prostitutas, mães solteiras, mulheres masculinizadas, mulheres escandalosas, boêmias, histéricas e outras. Em geral, o desvio passava pelo plano da sexualidade, que, na mulher, deveria ser muito bem observado e mensurado, pois aos excessos e descaminhos do padrão sexual normal eram especialmente creditadas as descontinuidades do feminino e, consequentemente, as rupturas com um determinado modo de proceder social esperado.

Quaisquer variações do padrão considerado sadio na prática sexual feminina eram enquadradas no plano dos desvios, bem conhecidos e reproduzidos por médicos, juristas e demais especialistas da época. As mulheres honestas, dignas e distintas eram opostas às prostitutas, bem como a todas aquelas que de alguma forma não se adequavam ao padrão social imposto. Era preciso identificar urgentemente os limites da sexualidade sadia e incentivar o seu exercício.

A sexualidade aceita, aquela considerada sã, serve como parâmetro para a construção daquela que é desviante e perigosa. Igualmente, a sexualidade ameaçadora é também a responsável por delimitar aquela que é segura. Assim, o mapeamento do periférico gera o normal, bem como a reafirmação do normal possibilita a existência do periférico. Tal construção de sexualidade desemboca na produção de subjetividades, ou seja, de sujeitos dotados de sexualidades categorizadas e descritas por saberes especializados. Os discursos de saberes geram condições e posições de sujeitos. As pessoas passam a ser especificadas, bem como a se compreender enquanto sujeitos de identidades baseadas em categorias criadas socialmente.

A heterossexualidade monogâmica passou a ser, a partir de meados do século XIX, a conduta sexual paradigmática da normalidade, sendo a mulher aquela que mais deveria cumpri-la, sob o risco de ser considerada desviante, impura ou histérica. Foucault destaca que, a partir do século XIX, houve "um movimento centrífugo em relação à monogamia heterossexual" (FOUCAULT, 2006, p. 45), que a retirou da pauta central das discussões sobre sexualidade, ficando confinada ao espa- 
ço do discreto, do recatado, do austero. O casamento, local exclusivo da permissão dos prazeres legítimos, espaço reservado à procriação, foco de austeridade necessária e intensidade almejada, representava, segundo o autor, a “(...) codificação das relações morais entre os esposos, sob o duplo aspecto de uma recomendação moral de reserva, e de uma lição complexa de comunicação afetiva através dos prazeres sexuais" (FOUCAULT,1997, p. 61).

No entanto, dizer que a célula familiar é espaço "respeitado" no plano da sexualidade, em momento algum é afirmar que ali não há uma rede complexa de poderes e incitações sexuais. Pelo contrário, Foucault argumenta que a casa da família burguesa é um espaço de articulação de saberes e poderes que são distribuídos por todos os cômodos, constituindo um espaço de saturação sexual. Na família a incitação gera regulamentação. A família surge como espaço de poder, prazer, saber e opressão, num ciclo constante de incitação e controle.

Os casamentos estimulados nas cidades em crescimento eram aqueles pautados no modelo da família burguesa, no qual um casal geneticamente perfeito tinha filhos sadios e bem educados. No casamento higiênico, de acordo com Costa, o ato sexual era estimulado, uma vez que "do bom desempenho sexual dos cônjuges dependia a saúde dos filhos, a moralidade da família e o progresso populacional da nação. O direito individual de gozar tornou-se, para a higiene, uma obrigação cívica" (COSTA, 1999, p. 229). O sexo no casamento era garantia de sexo sadio, sem doenças e, portanto, incitado. Era o sexo legítimo e lícito.

De acordo com Foucault, nos séculos XVIII e XIX, o foco central da interrogação oficial passou a ser a sexualidade do outro: a criança onanista, o perverso, os loucos, os criminosos, as prostitutas. Nesse contexto era necessário conter as sexualidades desviantes, aquilo que fugia à regra e à norma. Era preciso conter o outro. Anne-Marie Sohn, ao analisar os caminhos do controle sobre o corpo, ressalta a análise foucaultiana segundo a qual "a burguesia do século XIX, com sua 'vontade de saber' e de controle dos corpos, havia definido uma biopolítica do sexo que tinha como intuito normalizar os comportamentos privados pelo controle das mulheres, das crianças e da sexualidade não reprodutiva" (2008, p. 118). Por meio 
das sexualidades periféricas cria-se o normal, estabelecendo-se o padrão do saudável, aceito e descente.

Foucault analisa alguns casos de produção de saberes e poderes específicos acerca do sexo que, a partir do século XVIII, são alvo de constante classificação, controle e ação. São eles a histerização do corpo feminino, a pedagogização do sexo da criança, a socialização das condutas de procriação e a psiquiatrização do prazer perverso (FOUCAULT, 2006, pp. 114 e 115). A histerização do corpo feminino se deu, segundo o autor, a partir de um processo tríplice pelo qual o corpo da mulher foi analisado como sendo um corpo saturado de sexualidade; foi associado ao campo das práticas médicas, principalmente por ser um corpo essencialmente dotado de patologias; bem como foi coligado ao corpo social (por meio da reprodução), ao espaço familiar e aos cuidados para com as crianças (FOUCAULT, 2006, p. 115).

A historiadora Magali Engel, em artigo intitulado Psiquiatria e Feminilida$d e$, analisa a regulamentação e o controle exercidos por saberes especializados sobre os corpos femininos considerados doentes, no final do século XIX, início do século XX. O corpo feminino, enquanto lugar central das intervenções normalizadoras, é apresentado pela autora como um laboratório de saberes médicos psiquiátricos é no corpo que está toda a doença e toda a cura para ela. A autora mostra como são contraditórios os estudos acerca das "doenças femininas" e das técnicas para curá-las. Alguns creditavam a histeria ao exercício maior ou menor do sexo, bem como à quantidade e freqüência desse exercício. Alguns viam o estado puerperal como extremo perigo para a saúde mental feminina, enquanto outros como a cura para as doenças mentais femininas.

Apesar dos posicionamentos contraditórios, segundo a autora, os alienistas da época percorriam o mesmo caminho para detectar e tratar a histeria: a correlação desta com o útero e o cérebro, bem como a direta consideração da sexualidade feminina como determinante para a doença. Divergiam apenas quanto à cura e as causas, criando um universo de contradições difícil de ser contornado. Em suas palavras: 
entre os muitos desdobramentos recorrentes da transformação do casamento em uma instituição higiênica, temos não apenas o reconhecimento, mas o estímulo à sexualidade feminina. Para os médicos, a ausência ou a precariedade da vida sexual poderiam resultar em conseqüências funestas para as mulheres: como o hábito da masturbação - causador da esterilidade, ou aborto - ou o adultério. Assim como a ausência ou insuficiência da vida sexual, os excessos ou perversões na realização do desejo e do prazer conduziriam a mulher fatalmente aos mesmos temidos destinos. Assim, a sexualidade só não ameaçaria a integridade física, mental e moral da mulher, caso se mantivesse aprisionada nos estreitos limites entre o excesso e a falta e circunscrita ao leito conjugal (ENGEL, 1997, p. 342).

Vale frisar que a saúde mental nas mulheres representava, juntamente com a dos homens a reprodução sadia que tanto almejavam os eugenistas. Assim, era necessário conter a loucura e, quando não fosse possível, impedir que esta se espalhasse pela reprodução. A higiene mental tornou-se preocupação central de médicos, eugenistas e higienistas da primeira metade do século XX, para quem era preciso erradicar a loucura de modo a garantir uma nação sã. Os higienistas e psiquiatras investiram energia para combater a loucura em diferentes espaços sociais, como as escolas, os lares e as ruas (STEPAN, 2005, p. 58).

São exemplos do esforço de sanear os costumes e os espaços e adequá-los a um modelo específico: a tentativa de inculcar ordem e domesticidade à classe operária, por meio da valorização do modelo de família nuclear; as grandes reformas urbanas e conseqüente derrubada de cortiços e organização da cidade; o mapeamento dos espaços de prostituição e sua regulamentação; a medicalização do corpo feminino, que era objeto de intervenção de uma política reprodutiva eugênica; identificação das drogas da moda, como cocaína, éter, morfina e ópio e "regulamentação" dos seus espaços de uso, dentre outros. De acordo com Stepan, “o regime Vargas ampliou o poder do Estado para gerenciar e controlar grupos 'socialmente problemáti- 
cos' como os doentes mentais, as prostitutas e os delinqüentes juvenis" (STEPAN, 2005, p. 173). O papel da polícia na identificação, mapeamento e aprisionamento do "outro" era de suma importância nesse contexto.

O outro é criado, segundo Foucault, por meio da "implantação das perversões múltiplas" - "efeito-instrumento" que isola, intensifica e consolida as sexualidades periféricas, permitindo que as relações entre sexo, poder e prazer se articulem, de modo a interferir no corpo e penetrar nas condutas (FOUCAULT, 2006, p.56). O outro passa a ser o principal alvo do poder disciplinar e regulamentar. Assim, aqueles que desviam de uma conduta social tida como normal deveriam de alguma forma ser perseguidos e levados aos espaços do outro: “(...) conselhos de disciplinas, as casas de correção, as colônias penitenciárias, os tribunais e asilos" (FOUCAULT, 2006, p. 47). O que não é normal deve sofrer as conseqüências de não sê-lo. $O$ "outro" deveria ser vigiado, isolado, extirpado e/ou identificado e mapeado. Era necessário saber onde estava o perigo, quem colocava a sociedade que se buscava construir em risco, e como proceder para prevenir que o "outro" se tornasse a regra.

Especificamente em relação aos desvios do feminino, a prostituta era, por excelência, o extremo do desvio. Mulher de sexualidade descontrolada, de vários homens, de impulsos bestiais, de postura escandalosa, potencialmente repleta de doenças venéreas, destruidora de lares, gananciosa, egoísta, degenerada, doente - o oposto do modelo ideal de mulher nas primeiras décadas do século XX. Segundo Rago a prostituição surge com o processo urbano que privilegiava a família burguesa monogâmica como núcleo da sociedade que se expandia. O lugar do desviante era aquele da sexualidade insubmissa, que deveria ser domada e padronizada nos modelos dessa família padrão (RAGO, 2008). De acordo com Costa, "as prostitutas tornaram-se inimigas dos higienistas principalmente pelo papel que supostamente tinham na degradação física e moral do homem, e, por extensão, na destruição das crianças e da família" (COSTA, 1999, p. 265). Ainda, para Rago,

'mulher pública', a prostituta foi percebida como uma figura voltada para o exterior, mulher do mundo sem vínculos nem freios, ao contrário da mãe, toda interioridade, confi- 
nada ao aconchego do espaço privado. Na superfície do seu corpo os médicos leram os traços de sua estrutura psicológica: no tamanho dos quadris, na largura da testa, no comprimento dos dedos decifraram os sinais de uma anormalidade estrutural. Pelo estudo anatômico do seu corpo, construíram sua identidade e o lugar da manifestação do seu desejo sexual (RAGO, 2008, p. 174).

Rago salienta que, com o aumento da prostituição nos centros urbanos, é possível identificar dois espaços bem diferenciados do seu exercício: os cabarés de luxo, voltados para um público de classe alta, ou seja, os "doutores" da elite; e o baixo meretrício, muito menos glamoroso, freqüentado pela classe baixa. Os cabarés elegantes eram espaços aceitos na cidade como sendo “(...) ambientes masculinos de prazer, onde se podia dançar acompanhado das cocotes, ao som de valsas bem tocadas, ou onde os homens jogavam pôquer e podiam consumir cocaína, éter e demais drogas da moda" (RAGO, 2008, p. 119). A prostituição de luxo, associada aos renomados cabarés franceses, apesar de mal vista, se inseria em uma lógica capitalista e moderna, sendo aceita como espaço necessário na "geografia dos prazeres" das cidades em crescimento (RAGO, 2008, pp. 95 a 124). Em outras palavras, no mapa dos "amores ilícitos" os cabarés da elite ao mesmo tempo em que eram considerados locais de devassidão, de exercício da infidelidade e de risco à família, eram considerados "mal necessário" em uma sociedade que via no casamento o lugar legítimo para exercício da sexualidade, criando regras rigorosas em torno da virgindade feminina.

Já o baixo meretrício era associado constantemente à pobreza, à boemia exacerbada, às doenças e ao descontrole. Era o espaço do exercício de uma sexualidade suja, perigosa e enferma. Eram espaços não regulamentados, não planejados, geralmente ocupando as periferias das cidades ou locais degradados. Era no baixo meretrício que morava o maior perigo das famílias e da saúde: mulheres depravadas, doenças venéreas, vadiagem e excessos. Segundo Rago,

se o mundo da prostituição chique pode ser metaforizado com imagens que evocam prazer e tranquilidade, ao mesmo tempo que violência e depravação, o baixo meretrício vem 
invariavelmente associado à idéia de animalidade da carne, da bestialidade do sexo, do gozo irrefreável e da orgia sem limites, atestando o último degrau da degradação atingido pela humanidade. Tudo ai passa pelo crivo do negativo, do sombrio, da brutalidade humana (RAGO, 2008, p. 273).

Para além dos desvios vinculados à prostituição havia também os preconceitos voltados à mãe solteira e à mulher que não queria se casar: ambas eram marginalizadas em uma época na qual o casamento tinha um altíssimo valor social. Ser mãe solteira era uma vergonha à família e à mulher, sendo constantemente, tanto nas classes altas quanto nas baixas, a gravidez, nessas condições, interrompida com o aborto (SOIHET, 1997, p. 380). Não querer se casar, por sua vez, era não só não querer reproduzir a nação, mas também fugir de uma conduta "natural" esperada das mulheres adultas.

Maria Clementina Pereira Cunha, em pesquisa histórica sobre o asilo do Juqueri, em São Paulo, enfatiza o "lugar da loucura" ocupado pela mulher nas primeiras décadas do século XX. O descumprimento de funções sociais dela esperada, e/ou de suas obrigações naturais, como ter filhos, tornava-a, aos olhos da sociedade, facilmente figura desviante, portadora de distúrbio de ordem psíquica. A autora ressalta que "no caso das mulheres, a busca do estranho é sensivelmente mais refinada e incisiva”, sendo a patrulha da loucura feminina acirrada. Associada pelos alienistas, em geral, à sexualidade desviante, a loucura feminina recebia especial atenção da literatura médica, que ao descrever as patologias próprias do sexo em questão, via de regra, ressaltava elementos como apatia sexual, muito apetite sexual, excesso de erotização, dentre outros. De acordo com Cunha:

vestir-se como homem, viajar só. Recusar o casamento, a maternidade, a família. Manifestar uma independência essencialmente estranha àquela sociedade. No caso da loucura feminina a transgressão não atinge apenas as normas sociais, senão à própria natureza, que a destinara ao papel de mãe e esposa (CUNHA, 1988, p. 144). 
Ainda, ocorria, também, a condenação das formas de vida das classes populares, em cortiços e lugares degradados das cidades em crescimento, nos quais as famílias se misturavam e os filhos, fossem oriundos de casamentos, ou de relações não conjugais, eram criados fora de um núcleo familiar identificável. Eram espaços que abrigavam "o outro", a classe perigosa. Tudo o que fugia ao modelo da família burguesa e higiênica significava um desvio do caminho correto das famílias, devendo o Estado se preocupar com esses espaços, pois eram locais de degenerescência e perdição. Locais "não civilizados" deveriam sofrer intervenção, ser demolidos e erradicados dos espaços citadinos. Um artigo não assinado da revista $A$ Estrela, escrito em 1951, é certeiro ao vincular aumento de criminalidade e locais de moradia "não higiênica", quando frisa que:

os motivos que levam os criminosos à prática do delito, e até mesmo a sua repetição, existem em todas as classes sociais, mas o fato se consuma, quase sempre, nos desprotegidos da felicidade do amparo social e econômico. Os mananciais do crime não estão nos bairros operários, onde habita gente pobre mas ocupada, tampouco ele está na vila de pequenos funcionários, nem nos bairros onde reside a abastança; são as favelas imundas, os botequins - esses lúgubres e infectos repositórios de micróbios da alma - e, principalmente, nos degradantes canteiros da herva da perdição: no meretrício, onde nascem, crescem e difundem-se os espécimes (AE, maio de 1951, s/p).

Contemporaneamente, a historiadora Rachel Soihet chama a atenção para a derrubada dos cortiços cariocas no início do século XX e para as dificuldades vividas pelas mulheres que habitavam e trabalhavam como costureiras e lavadeiras nesses espaços, uma vez que não só perdiam suas casas, mas também seus locais de trabalho (Soihet, 1997, pp. 364 e 365). Nesse sentido vale citar Soihet, segundo a qual:

(...) ao contrário dos 'bem situados' que se guardavam dentro de suas mansões, protegidas por altos muros, os pobres, homens e mulheres, tinham nas ruas e praças o espaço de 
seu lazer, em muitas das quais se buscava impedi-los de circular livremente, sendo a todo momento incomodados pela polícia (SOIHET, 1997, p. 365).

Por fim, nesse cenário deve ser realçado o lugar ocupado pela população negra e mestiça brasileira nas cidades em crescimento. Ex-escravos ou descendentes de escravos, os negros moravam, em geral, em espaços degradados e trabalhavam nos cargos menos qualificados e remunerados disponíveis. A associação entre negros e atraso, ou entre estes e a degenerescência era constante. Os negros representavam para muitos o passado de atrasos que o Brasil moderno desejava superar, ao mesmo tempo em que formavam um grande contingente populacional, impossível de ser varrido das cidades. Marginalizada, esta população era estereotipada como sendo indolente, pouco produtiva e subdesenvolvida, fadada à pobreza e à miséria. De acordo com Stepan, médicos, sanitaristas e pensadores brasileiros “(...) presumiam que doenças sociais se acumulavam na base da hierarquia sócio-racial - que os pobres eram pobres porque eram anti-higiênicos, sujos, ignorantes e hereditariamente inadequados" (STEPAN, 2005, p. 47). A associação do negro aos preconceitos de um passado escravista auxiliava na marginalização dessa população e na construção de estereótipos raciais que a degradavam. Havia um controle social voltado para a população negra, uma vez que ela representava a desordem na cena da cidade. Segundo Stepan:

a fé da intelligentsia na capacidade da branquidade em dominar a negritude foi reforçada pelo continuado uso de mecanismos informais de controle social sobre a mobilidade dos negros, bem como das formas mais institucionalizadas de repressão, como o uso da polícia para manter a 'ordem' social e racial (STEPAN, 2005, pp. 166 e 167).

O investimento no branqueamento da população foi incentivado pelos cientistas a partir de meados dos anos de 1920, como forma de garantir a purificação da "raça brasileira". Tanto a chegada dos imigrantes europeus, como o incentivo de casamentos entre brancos e mestiços de modo a branquear a raça foram estratégias utilizadas para eliminar os negros do seio social e construir uma nação cada vez mais 
branca e racialmente homogênea. O "bom mestiço" seria o fruto dos cruzamentos raciais, e resultado de uma purificação dos caracteres degenerados de gerações anteriores (SCHWARCZ, 2008, p. 214 a 217). A questão racial era crucial no momento de formação da nação civilizada que se pretendia o Brasil, sendo um dos temas centrais dos quais se ocupavam médicos e demais cientistas do período. O lugar social ocupado pela população negra não poderia receber destaque aos olhos dos estrangeiros, que deveriam enxergar o Brasil como um país cada vez mais civilizado e competitivo no mercado mundial. Assim, a difícil decisão sobre o que fazer com a raça negra desembocou no estímulo da mestiçagem.

Nesse contexto, é fundamental apontar o lugar das mulheres negras e mestiças na paisagem das primeiras décadas do século XX. Marginalizadas e subvalorizadas, estas mulheres eram vistas como inferiores às brancas. Herdeiras das mucamas escravas as negras eram consideradas seres dotados de sexualidade exacerbada, erotizadas ao extremo. Ocupavam espaços sociais considerados degradantes, sendo, em sua maioria, moradoras de cortiços e favelas. Muitas eram as responsáveis pelo sustento do lar, trabalhando fora para garanti-lo. Rago frisa que:

sabemos que sua condição social quase não se alterou, mesmo depois da abolição e formação do mercado de trabalho livre no Brasil. Os documentos oficiais e as estatísticas fornecidas por médicos e autoridades policiais revelam um grande número de negras e mulatas entre empregadas domésticas, cozinheiras, lavadeiras, doceiras, vendedoras de rua e prostitutas (...) (RAGO, 1997b, p. 582).

Em suma, nas rotas do desvio estavam aquelas que eram discrepantes na paisagem urbana ideal. As mulheres escandalosas, as vestidas de maneira vulgar, as prostitutas, as moradoras de favelas e cortiços, as que freqüentavam locais masculinos, as que se expunham ao mundo do trabalho, as negras e mestiças, as criadas e empregadas. Em um cenário mais amplo, é possível atribuir a criminalização dessas mulheres não apenas à criminalização dos desvios do feminino, mas também à criminalização da pobreza, uma vez que quem era pobre potencialmente poderia ser criminoso, 
pois habitava e frequentava locais "degenerados", como os cortiços e o baixo meretrício. Além disso, a legislação do país criminalizava condutas como a vadiagem e a mendicância, ou seja, agentes que não tinham empregos regulamentados, moradia, e que perambulavam pela cidade, evidenciando a desigualdade social e a desordem no espaço que tanto se buscava "civilizar". Pela prática punitiva do período é possível pontuar os "agentes do desvio" que se buscava punir, esconder e trancafiar.

\section{AGENTES DO DESVIO}

\section{E O SISTEMA DE JUSTIÇA CRIMINAL}

Para mapear a criminalidade feminina, de modo a identificar quais os desvios responsáveis pelas principais denúncias, detenções e prisões das mulheres, recorreu-se a dados estatísticos e a análises sobre a criminalização no período estudado. Considerando as delineações das figuras desviantes traçadas anteriormente, é possível afirmar que existe uma associação entre as rupturas com um esperado "dever ser" feminino e a criminalização de mulheres consideradas desviantes. A profissão, a classe social, a mobilidade no espaço público, dentre outros elementos, são importantes indicadores da perseguição a determinados estereótipos femininos, considerados os mais propensos à prática de condutas criminosas.

Tal mapeamento foi realizado por meio da análise de anuários estatísticos da Polícia Civil do Estado de São Paulo, produzidos no final da década de 1930 e primeiros anos da década de 1940, bem como por meio de dados apresentados em um artigo sobre o aprisionamento feminino no início da década de 1950, escrito por Hilda Macedo, assistente da cadeira de Introdução à Criminologia da Escola de Polícia, publicado no periódico Arquivos da Sociedade de Medicina Legal e Criminologia de São Paulo. Os dados encontrados permitem levantar alguns pontos acerca da criminalidade feminina no período.

Vale ressaltar, no entanto, que embora os anuários apresentem dados detalhados sobre a criminalidade feminina, há elementos que não são passíveis de análise, seja porque não constam no relatório, seja pela gama de crimes e condutas ilícitas 
não notificadas e, portanto, não registradas nos dados oficiais. Assim, o mapeamento feito a seguir tem limitações claras de uma pesquisa histórica baseada, principalmente, em documentos e dados oficiais que são falhos em alguns aspectos. Além disso, vale ressaltar ponto abordado pelo historiador Boris Fausto em sua pesquisa sobre a criminalidade em São Paulo entre os anos de 1880 e 1924. Segundo ele, é importante, ao analisar estatísticas criminais históricas, considerar que:

os dados imprecisos que chegam até nós tendem a mesclar pelo menos dois elementos de difícil separação: a criminalidade real, entendida na sua acepção simples de infração às normas do código penal, e a atividade policial, que vai muito alem da prisão de eventuais criminosos, exercendo uma atividade de amplo controle social (FAUSTO, 2001, p.41).

O papel de manutenção da ordem pública desempenhado pela polícia, por meio de ações visando a um rigoroso controle social, justificava a detenção de indivíduos considerados suspeitos, o que, como ressaltado por Fausto, denota um comportamento incriminador a priori. De acordo com o autor, no início do século XX, “as prisões contravencionais, bem como as realizadas para 'averiguações', revelam uma estrita preocupação com a ordem pública, aparentemente ameaçada por infratores das normas do trabalho, do bem-viver, ou simplesmente pela indefinida figura dos 'suspeitos"” (FAUSTO, 2001, p. 44). Tal quadro continua existindo nas décadas de 1930 e 1940, como é possível verificar pelas taxas de detenções policiais e correcionais apresentadas abaixo.

Os anuários do Serviço de Estatística Policial do Estado de São Paulo apresentam dados relevantes para a análise das mulheres presas e dos crimes atribuídos à autoria feminina no período analisado. Trata-se de relatório minucioso publicado desde 1938 contendo informações sobre detenções policiais, detenções correcionais, tipos de contravenções e crimes cometidos, aprisionamentos após condenação, por prevenção e em flagrante, ocorridos na capital e no interior do estado de São Pau- 
$\mathrm{l}^{55}$. Com o alegado motivo de revelar características fundamentais da criminalidade no estado e na cidade de São Paulo, de modo a "facultar aos estudiosos possibilidades de pesquisa sobre a delinquência e o delinquente", para facilitar a adoção de "medidas profiláticas, saneadoras e preventivas de eventos criminais", o Anuário "focaliza, em seus múltiplos aspectos, os fatos moralmente negativos ocorridos no estado de São Paulo durante o ano de 1943" (EPCSP, 1944, p. 9).

Dentre os dados do Anuário selecionados para o presente trabalho estão aqueles que permitem mapear as principais razões das detenções e aprisionamentos feminino no período, verificar quais crimes cometidos por mulheres foram notificados, bem como expor o perfil dessas mulheres, com base em dados como cor, idade, nacionalidade e estado civil. Assim, foram analisados quatro tipos de tabelas principais: I) os que contêm dados sobre detenções policiais e correcionais ocorridas na cidade de São Paulo e no interior do Estado; II) os que tratam dos delitos ocorridos (e notificados) na cidade de São Paulo; III) os que tratam dos aprisionamentos ocorridos na capital e no interior, tanto por condenações definitivas quanto por prisões provisórias; IV) e os que tratam dos dementes detidos na capital e no interior.

Os dados sobre detenções policiais e correcionais ${ }^{56}$ efetuadas no estado de São Paulo eram, segundo o Anuário, relevantes para a realização de “(...) estudo confrontativo das manifestações anti-sociais" - as contravenções - que embora fossem "pequenas falhas morais", e não crimes, eram em parte solucionadas pelas detenções policiais e correcionais que permitiam “(...) a observação do comportamento moral dos cidadãos que formam um agrupamento humano e que por isso mesmo requerem uma exaustiva vigilância e ininterrupto conhecimento de suas causas geradoras" (EPCESP, 1944, p. 15). Vale ressaltar que os comportamentos previstos na Lei das Contravenções Penais (Decreto-Lei No 3.688 - outubro de 1941) são transgressões de menor potencial ofensivo, ou seja, atos ilegais que são punidos com prisão sim-

55 Optou-se por trabalhar com os dados do anuário de 1943, pois ele é comparativo dos volumes anteriores, publicados, respectivamente, em 1938, 1939, 1940, 1941 e 1942.

56 Detenções feitas pela polícia, autorizada a apreender sujeitos contraventores. A detenção funcionava como um corretivo, e o detido estava sujeito ao processo policial, podendo haver condenação ao final. 
ples ou multa. Já os previstos no Código Penal (Decreto-Lei No 2.848 - dezembro de 1940) são denominados crimes, para os quais são previstas penas de multa, penas privativas de liberdade, penas restritivas de direitos e medidas de segurança.

Segundo o Anuário de 1943, o número de detenções policiais e correcionais verificadas no Estado de São Paulo foi de: I) 41.043 no ano de 1937; II) $46.336 \mathrm{em}$ 1938; III) 48.742 em 1939; IV) 48.261 em 1940; V) 45.786 no ano de 1941; VI) e 47.789 em 1942. O principal motivo de detenções policiais e correcionais apontado desde o relatório de 1938 era o alcoolismo e a desordem a qual, de acordo com o relatório, decorre, em geral, do primeiro. Durante o ano de 1943, no estado de São Paulo, verificaram-se 42.544 detenções policiais e correcionais (destes, 31.322 no interior do estado, o que corresponde a 62\%, e 11.222 na capital ou 38\%). A tabela 1 abaixo mostra as detenções policiais e correcionais ocorridas no interior do estado de São Paulo e na capital no ano de 1943, de acordo com os motivos que ocasionaram as detenções e segundo o sexo dos detidos, possibilitando um panorama do total de detenções no estado.

TABELA 1. DETENÇÕES POLICIAIS E CORRECIONAIS NO ESTADO DE SÃO PAULO (1943)

\begin{tabular}{|c|c|c|c|c|}
\hline CRIMES & $\begin{array}{l}N^{\circ} \text { HOMENS } \\
\text { CAPITAL }\end{array}$ & $\begin{array}{l}N^{\circ} \text { HOMENS } \\
\text { INTERIOR }\end{array}$ & $\begin{array}{l}N^{\circ} \text { MULHERES } \\
\text { CAPITAL }\end{array}$ & $\begin{array}{l}\mathbf{N}^{\circ} \text { MULHERES } \\
\text { INTERIOR }\end{array}$ \\
\hline AVERIGUAÇÕES & 751 & 9610 & 38 & 647 \\
\hline ALCOOLISMO & 2669 & 9261 & 478 & 1218 \\
\hline DESORDEM & 5176 & 5114 & 900 & 1106 \\
\hline AGRESSÃO & 287 & 355 & 24 & 28 \\
\hline DESOBEDIÊNCIA & 91 & 927 & 18 & 212 \\
\hline ESCÂNDALO & 48 & 133 & 60 & 285 \\
\hline $\begin{array}{c}\text { INSULTOS, } \\
\text { OFENSAS E } \\
\text { PROVOCAÇÕES }\end{array}$ & 198 & 363 & 24 & 67 \\
\hline $\begin{array}{l}\text { ÓCIO OU } \\
\text { VADIAGEM }\end{array}$ & 22 & 932 & 17 & 138 \\
\hline MENDICIDADE & 263 & 168 & 81 & 53 \\
\hline JÔGO & 12 & 213 & - & - \\
\hline $\begin{array}{l}\text { PEQUENO } \\
\text { FURTO }\end{array}$ & 8 & 137 & 3 & 8 \\
\hline $\begin{array}{l}\text { DE ORDEM DE } \\
\text { AUTORIDADES } \\
\text { DIVERSAS }\end{array}$ & ------ & 343 & ------ & 9 \\
\hline TOTAL & 9579 & 27551 & 1643 & 3771 \\
\hline TOTAL GERAL & \multicolumn{4}{|c|}{42544} \\
\hline
\end{tabular}


Sobre estes dados, um primeiro ponto que merece destaque é a grande diferença no número de homens e mulheres detidos, sendo diminuto o índice de detenção feminino em comparação ao masculino, tanto na capital quanto no interior, cenário que se repete nos anuários anteriores a 1943. As mulheres detidas na capital e no interior em 1943 representam 12,7\% do total de detenções ocorridas, enquanto os homens foram $87,3 \%$.

O alcoolismo foi, no ano de 1943, a principal causa geradora de detenções correcionais. Em todos os anuários analisados, aparece como principal "responsável pela degeneração social e moral dos indivíduos". Segundo texto do Anuário de 1943, “(...) o governo deve cada vez mais tomar medidas saneadoras e protetoras da coletividade evitando que o alcoolismo degenere a raça, formando irresponsáveis bandos de deficientes, atrasados mentais, vagabundos, criminosos, pequenos delinquentes, e o contingente enorme de mortalidade infantil" (EPCSP, 1944, p. 15). Fator de risco para a ordem pública, o alcoolismo preocupava as autoridades policiais, que buscavam contê-lo por meio do aprisionamento dos ébrios, uma vez que "agindo impulsionado por esse freio inibidor da vontade, o alcoolista por um nada descamba para o terreno das imoralidades das inconveniências quando não é levado a perpetrar delitos de maior gravidade" (EPCSP, 1944, p. 14). É alta a quantidade de mulheres detidas por alcoolismo tanto na capital quanto no interior, representando $31,3 \%$ do total das detenções femininas.

Sobre a rubrica de desordem foram detidas $37 \%$ do total das mulheres apreendidas na capital e no interior. Apesar de não ser uma contravenção tipificada na Lei das Contravenções Penais, a desordem abrange inúmeros comportamentos considerados anti-sociais, como aquele previsto no artigo 42 dessa Lei, que prescreve pena aos que perturbam o trabalho ou o sossego alheios, ou o previsto no artigo 61, que considera contraventor aquele que importuna a ordem pública de modo ofensivo ao pudor. De todas as condutas responsáveis por detenções correcionais e policiais na capital e no interior do estado de São Paulo, a única pela qual o número de mulheres detidas supera o de homens detidos é o "escândalo". "Causar escândalo" em público, prática associada à embriaguez, prevista no arti- 
go 62 da Lei das Contravenções Penais, foi conduta responsável pela detenção de 181 homens e 345 mulheres no estado de São Paulo, diferença numérica que não representa uma surpresa, considerando o recato esperado das mulheres em suas atitudes públicas.

As contravenções penais em geral, mas em especial aquelas constantes no capítulo VII da Lei, relativas às políticas de costumes, são as condutas consideradas antissociais em uma sociedade que buscava edificar-se sob a égide da ordem, da moral e dos bons costumes. A valorização do trabalho e do recato e o combate aos vícios guiam muitos dos tipos de contravenção previstos na Lei. Por exemplo, segundo o sociólogo Luís Antônio Francisco de Souza, em pesquisa histórica sobre a Polícia Civil e práticas policiais na São Paulo republicana (de 1989 a 1930), a definição de vadiagem como contravenção penal foi manobra política para a valorização do trabalho. As preocupações centrais nesse sentido eram: "a) coibir a vadiagem, fazendo com que os indivíduos fixassem suas residências; b) refrear a criminalidade; c) punir e regenerar o criminoso; e d) construir uma nova ordem social baseada na idéia de ordem pública” (SOUZA, 2009, p. 407).

A possibilidade da detenção para averiguação, bem como de detenções correcionais e policiais nos casos de práticas de contravenções penais, dava ampla margem para a atuação policial, que deveria zelar pela ordem pública, podendo retirar temporariamente do convívio social aqueles que provocassem algum tipo de desordem nesse cenário. Vale ressaltar que o processo para a condenação de contraventor era realizado majoritariamente pelo delegado de polícia, que encaminhava um parecer valorativo ao juiz, para que este pudesse, então, sentenciar. O processo policial, como era chamado, dava amplos poderes ao delegado, uma vez que ao conduzir o processo, inclusive a audiência, produzindo um relatório final, dava pouca margem para o juiz desautorizá-lo e pedir novas diligências, pois fora ele, a autoridade policial, quem acompanhara o processo desde sua abertura. Souza, ao falar da prática da contravenção de vadiagem, ressalta a possibilidade de a polícia deter os cidadãos sem que houvesse ordem judicial para tal, em uma dinâmica na qual "a justiça parecia se convencer da necessidade social da perseguição à vadiagem, mesmo que as regras do 
direito saíssem um pouco chamuscadas. Portanto, no processo policial, o acusado era detido e mantido preso sem base legal (...)" (SOUZA, 2009, p. 443).

Em relação à faixa etária das mulheres detidas no estado de São Paulo em 1943, pode-se notar um predomínio de mulheres jovens, entre 18 e 30 anos de idade. Trata-se de faixa etária de maior vulnerabilidade em relação ao sistema de justiça criminal. ${ }^{57} \mathrm{O}$ gráfico 1 mostra a proporção de detenções por faixa etária.

\section{GRÁFICO 1. DISTRIBUIÇÃO DE MULHERES}

DETIDAS NA CAPITAL E NO INTERIOR SEGUNDO FAIXA ETÁRIA (1943)

\section{Capital}

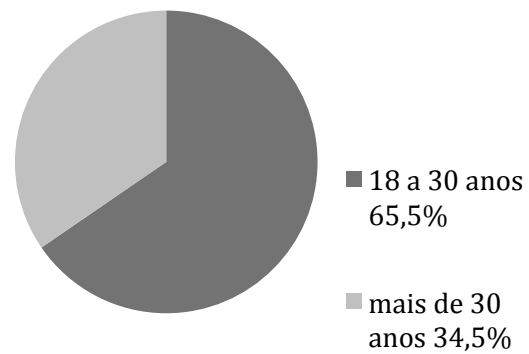

Interior

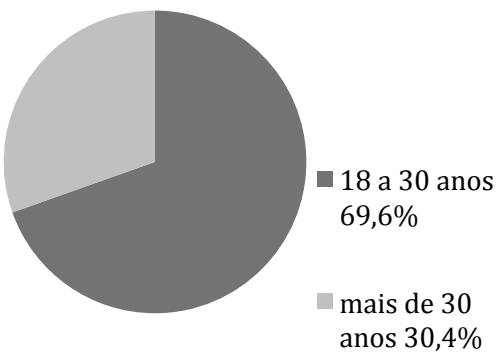

Em relação ao estado civil, a maioria das detidas no estado de São Paulo em 1943 era solteira - 53\% das mulheres na capital e 49\% no interior. Do total de detidas, as casadas representavam 32\% das mulheres da capital e 35\% no interior, e as viúvas, $15 \%$ na capital e $14 \%$ no interior. Enquanto $51,7 \%$ das mulheres detidas na capital declararam não ter filhos, apenas $23,8 \%$ declararam tê-los. Já as mulheres que foram fichadas como sendo solteiras representam $52,5 \%$ do total de detidas na capital, ao passo que as casadas, $32,4 \%$ e as viúvas, $15,6 \%$. Ainda, das detidas na capital, 34\% declararam não ter frequentado a escola, enquanto $66 \%$ receberam educação primária, ou seja, nenhuma foi além do primário.

57 Dados atuais do aprisionamento no Brasil mantêm concentração semelhante de detenção e aprisionamento de jovens entre 18 e 30 anos, segundo estatística do Ministério da Justiça disponível em http://portal. mj.gov.br/data/Pages/MJD574E9CEITEMIDC37B2AE94C6840068B1624D28407509CPTBRNN.htm. Acesso em $01 / 11 / 2011$. 
No tangente à nacionalidade, no ano de 1943 , aproximadamente $7,2 \%$ do total de mulheres detidas na capital eram estrangeiras, sendo esta proporção de 3,7\% para o interior. Em outras palavras, a maioria das mulheres detidas no estado de São Paulo era brasileira. A Tabela 2 expõe dados sobre a nacionalidade das detidas, indicando os países de origem das estrangeiras.

TABELA 2. DISTRIBUIÇÃO DE MULHERES DETIDAS NA CAPITAL E NO INTERIOR SEGUNDO NACIONALIDADE (1943)

\begin{tabular}{ccc}
\hline NACIONALIDADE & $\begin{array}{c}\text { ESTRANGEIRAS DETIDAS } \\
\text { NA CAPITAL }\end{array}$ & $\begin{array}{c}\text { ESTRANGEIRAS DETIDAS } \\
\text { NO INTERIOR }\end{array}$ \\
\hline ITALIANAS & 14 & 19 \\
LITUANAS & 20 & 6 \\
PORTUGUESAS & 42 & 23 \\
JAPONESA & 1 & 12 \\
ESTADUNIDENSES & 1 & - \\
ALEMÃS & 6 & 3 \\
ARGENTINAS & 1 & - \\
BOLIVIANAS & 4 & 22 \\
ESPANHOLAS & 9 & 2 \\
HÚNGARAS & 2 & 8 \\
IUGOSLAVAS & 4 & 8 \\
POLONESAS & 3 & 1 \\
ROMENAS & 3 & 3 \\
RUSSAS & 5 & 1 \\
SIRIAS & 1 & - \\
TURCAS & 1 & 1 \\
CHECOSLOVACAS & - & 1 \\
CHILENA & - & 1 \\
FRANÇA & - & 1 \\
INGLATERRA & - & 2 \\
IRLANDA & - & 8 \\
MÉXICO & - & 1 \\
PARAGUAI & - & 136 \\
URUGUAI & - & \\
TOTAL DE & 117 & \\
ESTRANGEIRAS & & 1 \\
\hline & & \\
\hline
\end{tabular}

Enquanto, segundo Fausto, entre 1894 e 1916 foram presos, em São Paulo, mais imigrantes, $(55,5 \%)$, que brasileiros, $(44,5 \%)$, os dados de detenções policiais e correcionais da década de 1940 mostram um cenário bem distinto, no qual os imigrantes correspondiam a 7,1\% do total de detidos na capital. Tal diferença se dá por algumas razões principais, sendo a mais relevante o fato de que, na década de 1940, a geração na faixa etária de maior incidência criminal já era filha e neta de 
imigrantes, dada a distância das principais levas de imigração ocorridas no final do século XIX, início do século XX. Se, como apontado por Fausto, no início do século XX os estrangeiros eram maioria na população da cidade, o mesmo não é verdadeiro nos anos 1940. Ademais, se, de acordo com o autor, "enquanto a correlação discriminatória entre criminalidade e população de cor constitui um elemento permanente ao longo de todo o período abrangido pela pesquisa, a correlação criminalidade/estrangeiro é conjuntural. Concentra-se no período da imigração em massa (...)", o mesmo pode ser dito da década de 1940, quando a conjuntura era de menor número de imigrantes que nas décadas anteriores (FAUSTO, 2001, p. 76). Vale ressaltar que no final da década de 1910 e nos primeiros anos da década de 1920, houve uma vinculação entre criminalidade, em especial relacionada à desordem pública, e os estrangeiros, dada a participação destes nas grandes greves ocorridas em São Paulo e ao posicionamento político libertário e de esquerda adotado por muitos deles, em especial pelos italianos, o que justifica, igualmente, um maior número de detenções destes que nos períodos posteriores (FAUSTO, 2001, p.81).

O Anuário apresenta, também, dados detalhados sobre a profissão das detidas no ano de 1943, conforme demonstram o Gráfico 2 e a Tabela 3.

Capital

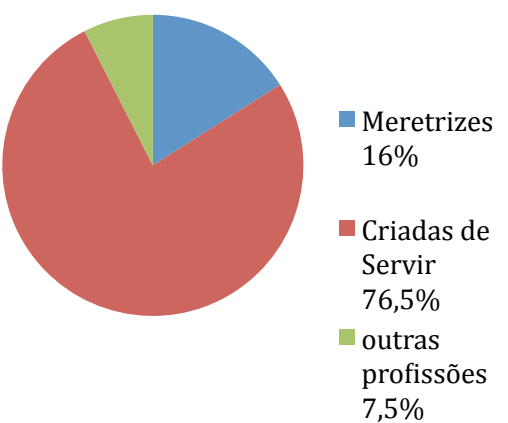

Interior

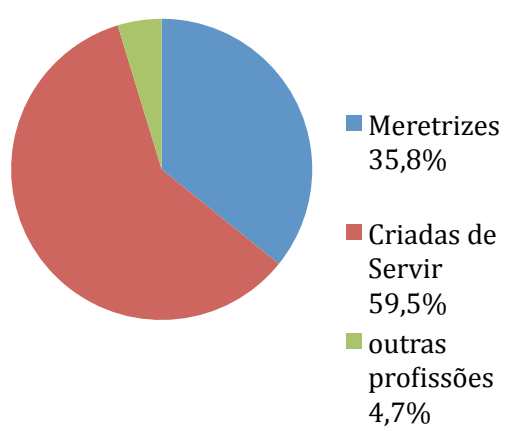


TABELA 3. MOTIVOS DA DETENÇÃO DE MULHERES POR PROFISSÃO NA CAPITAL E NO

INTERIOR (1943)

\begin{tabular}{|c|c|c|c|c|}
\hline MOTIVOS & $\begin{array}{l}\text { MERETRIZES } \\
\text { NA CAPITAL }\end{array}$ & $\begin{array}{c}\text { CRIADAS DE SERVIR } \\
\text { NA CAPITAL }\end{array}$ & $\begin{array}{l}\text { MERETRIZES } \\
\text { NO INTERIOR }\end{array}$ & $\begin{array}{l}\text { CRIADAS DE SERVIR } \\
\text { NO INTERIOR }\end{array}$ \\
\hline AVERIGUAÇÕES & - & 31 & 144 & 467 \\
\hline ALCOOLISMO & 66 & 391 & 478 & 676 \\
\hline DESORDEM & 182 & 658 & 472 & 594 \\
\hline AGRESSÃO & 4 & 17 & 143 & 15 \\
\hline DESOBEDIÊNCIA & - & & 63 & 142 \\
\hline ESCÂNDALO & 9 & 49 & - & 132 \\
\hline $\begin{array}{c}\text { INSULTOS, } \\
\text { OFENSAS E } \\
\text { PROVOCAÇÕES }\end{array}$ & - & 20 & 21 & 43 \\
\hline $\begin{array}{l}\text { ÓCIO OU } \\
\text { VADIAGEM }\end{array}$ & - & 17 & 12 & 113 \\
\hline MENDICIDADE & - & 56 & & 51 \\
\hline PEQUENO FURTO & - & 2 & 4 & 4 \\
\hline
\end{tabular}

As 42.544 detenções policiais e correcionais ocorridas no Estado de São Paulo no ano de 1943 mostram como a polícia de fato atuava na tentativa de contenção da desordem, perseguindo aqueles que desviavam de um "dever ser" aceito e estimulado: ter trabalho, não ter vícios, ter bom comportamento público eram as condutas estimuladas e paradigmáticas, que representavam a normalidade. Nesse contexto, as mulheres que freqüentavam de alguma maneira os espaços públicos estavam mais sujeitas às vigilâncias policiais, o que justifica o fato de a maioria das detidas pela polícia em 1943 ter uma profissão. As criadas de servir, apesar de trabalharem em geral nos ambientes privados, como as casas de família, frequentavam as ruas, e, mesmo dentro das casas particulares, estavam mais expostas aos controles sociais que aquelas que permaneciam resguardadas nos seus lares. A criminalização da classe trabalhadora é evidente quando analisados os dados desagregados por profissão, sendo, que, dentre as mulheres as criadas de servir compunham o grupo profissional mais atingido pelas detenções ${ }^{58}$.

58 Nesse sentido vale apontar a análise feita pela antropóloga Olívia Maria Gomes da Cunha ressaltando a vinculação, nas primeiras décadas do século XX, da empregada doméstica à criminalidade. Segundo a autora: "a associação entre trabalho doméstico e furtos é um tema constante na imprensa e em publicações especializa- 
Ainda em relação às profissões, vale frisar que o fato de a prostituição não ser crime justifica a criminalização das meretrizes com base nas contravenções que de alguma forma poderiam estar vinculadas à prostituição. $\mathrm{O}$ controle sobre essas mulheres se dava principalmente de modo a não permitir que a prostituição saísse dos espaços nos quais era tolerada, não perturbando os espaços moralizados da cidade. As apreensões, dentre as meretrizes, principalmente por alcoolismo, desordem e escândalo evidencia esse controle sobre o comportamento da prostituta.

Os dados referentes à cor mostram a criminalização de uma maioria de mulheres declaradas não brancas na capital, uma vez que somadas, as pardas e as pretas representam um contingente maior. Já no interior há praticamente um empate entre as declaradas brancas e as pretas e pardas. O gráfico 3 ilustra essas proporções.

\section{Capital}

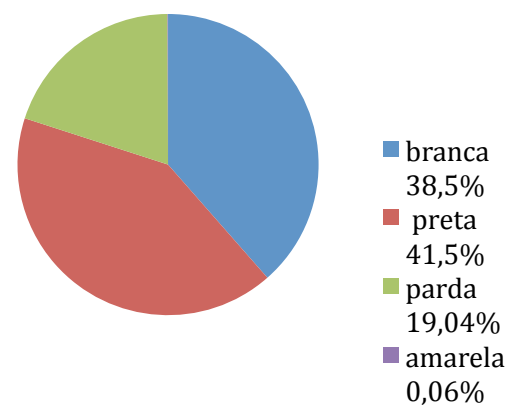

\section{Interior}

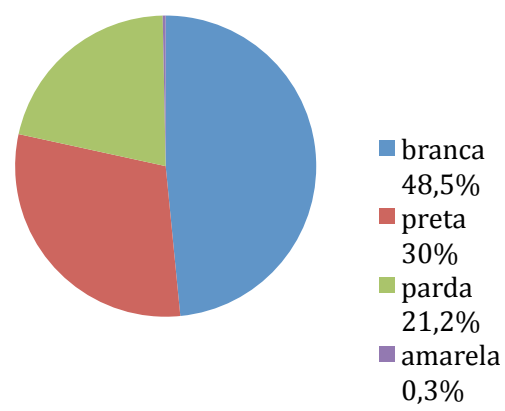

A preocupação com a ordem pública perpassava as classes consideradas "perigosas" e dentre estas estavam as pessoas de classe baixa, o operariado, as prostitutas, os imigrantes e os negros. No entanto, segundo Boris Fausto, no contexto de São

das em criminologia durante os anos de 1920 e 1930. Uma série de denúncias chega aos jornais, reforçando antigas propostas e esforços contemporâneos de obrigar os funcionários a se registrarem na polícia antes de se empregar nas "casas de família". A imagem da "criada ladra" alimentou a imaginação popular da capital do país num momento em que se verificava um relativo crescimento dos crimes cometidos por mulheres" (CUNHA, 2007, p. 411). O alto número de domésticas dentre as detidas nas estatísticas apresentadas, ilustra essa relação. 
Paulo é problemático considerar as punições por contravenções, como a desordem, um "instrumento repressivo a faixas da população discriminadas por cor”, pois se trata, antes, de atitudes contra "gentes suspeitas" estando a população negra dentre os suspeitos, figurando entre os estereótipos do desvio (FAUSTO, 2001, p. 48 e p. 71).

O Anuário de 1943 traz igualmente dados relevantes no tocante ao número de crimes registrados como cometidos na cidade de São Paulo. Desagregados, dentre outros, por sexo, profissão, idade e cor, tais informações, contidas na Tabela 4, denominada Características dos Delinquentes em Face do Código Penal e de outros Códigos ou Leis, permitem mapear quais condutas femininas eram mais notificadas e reprimidas, bem como quais as principais características das mulheres acusadas de as terem cometido. Optou-se por apresentar os dados referentes aos crimes do Código Penal, pois concentram a maioria das mulheres acusadas e/ou condenadas no período. A tabela a seguir ilustra os crimes cometidos na capital do estado de São Paulo segundo o sexo.

TABELA 4. CRIMES OCORRIDOS NA CAPITAL SEGUNDO SEXO (1943)

\begin{tabular}{|c|c|c|}
\hline $\begin{array}{c}\text { TÍTULO DO CÓDIGO } \\
\text { PENAL }\end{array}$ & $\begin{array}{c}\mathbf{N}^{\circ} \text { MULHERES NA } \\
\text { CAPITAL }\end{array}$ & $\begin{array}{c}N^{\circ} \text { HOMENS NA } \\
\text { CAPITAL }\end{array}$ \\
\hline $\begin{array}{c}\text { DOS CRIMES } \\
\text { CONTRA A VIDA }\end{array}$ & 335 & 2034 \\
\hline $\begin{array}{l}\text { DOS CRIMES } \\
\text { CONTRA O } \\
\text { PATRIMÔNIO }\end{array}$ & 111 & 1243 \\
\hline $\begin{array}{l}\text { DOS CRIMES } \\
\text { CONTRA O RESPEITO } \\
\text { AOS MORTOS }\end{array}$ & -------- & 1 \\
\hline $\begin{array}{l}\text { DOS CRIMES } \\
\text { CONTRA OS } \\
\text { COSTUMES }\end{array}$ & 5 & 236 \\
\hline $\begin{array}{c}\text { DOS CRIMES } \\
\text { CONTRA A } \\
\text { ASSISTÊNCIA À } \\
\text { FAMÍLIA }\end{array}$ & ------ & 14 \\
\hline $\begin{array}{c}\text { DOS CRIMES } \\
\text { CONTRA A SAÚDE } \\
\text { PÚBLICA }\end{array}$ & 2 & 8 \\
\hline $\begin{array}{l}\text { DOS CRIMES } \\
\text { CONTRA A FÉ } \\
\text { PÚBLICA }\end{array}$ & 3 & 15 \\
\hline $\begin{array}{c}\text { DOS CRIMES } \\
\text { CONTRA A } \\
\text { ADMINISTRAÇÃO } \\
\text { PÚBLICA }\end{array}$ & 8 & 47 \\
\hline TOTAL & 465 & 3598 \\
\hline
\end{tabular}


Chama a atenção o fato de $72 \%$ das mulheres registradas como delinquentes terem cometido crimes contra a pessoa, sendo a maioria deles lesões corporais leves. Já os crimes contra o patrimônio representavam 23,8\% dos crimes registrados sob autoria feminina.

Assim como nos índices de detenção no estado de São Paulo, a faixa etária entre 18 e 30 anos, concentra a maioria das mulheres acusadas e/ou condenadas por crimes na capital. Em relação ao estado civil há uma maioria de mulheres casadas, ou seja, $57 \%$ do total das acusadas e/ou condenadas na capital, $31 \%$ de solteiras e $8 \%$ de viúvas, dados que diferem do interior, que tinha uma maioria de solteiras entre as detidas. Já no tangente aos filhos é pequena a diferença entre as que têm, 33,5\%, e as que não têm, $36 \%$, filhos ${ }^{59}$. Destas mulheres, $23 \%$ não receberam educação formal, $71 \%$ tiveram educação primária e 1\% educação superior.

O índice de estrangeiras acusadas ou condenadas por crimes na capital é de aproximadamente $23 \%$, porcentagem alta quando comparadas às mulheres detidas no estado de São Paulo. A Tabela 5 especifica as nacionalidades das estrangeiras acusadas e/ou condenadas por crimes no estado de São Paulo, mostrando uma prevalência, entre as estrangeiras, de italianas, portuguesas, espanholas, alemãs e lituanas.

TABELA 5. DISTRIBUIÇÃO DE MULHERES ACUSADAS E/OU CONDENADAS POR CRIMES NA CAPITAL SEGUNDO NACIONALIDADE (1943)

\begin{tabular}{cc}
\hline NACIONALIDADE & MULHERES DELITUOSAS NA CAPITAL \\
\hline ITALIANAS & 16 \\
LITUANAS & 9 \\
PORTUGUESAS & 36 \\
ALEMÃS & 8 \\
ARGENTINAS & 1 \\
ESPANHOLAS & 12 \\
IUGOSLAVAS & 4 \\
POLONESAS & 4 \\
ROMENAS & 5 \\
RUSSAS & 5 \\
SíRIAS & 2 \\
NÃO ESPECIFICADAS & 4 \\
TOTAL DE & 106 \\
ESTRANGEIRAS & \\
\hline
\end{tabular}

59 Há um índice de 30\% sem especificação em relação à maternidade. 
Há uma continuidade no que se refere às profissões, que é a manutenção das domésticas e criadas de servir como a profissão principal das acusadas e/ou condenadas pela prática de crimes na capital. Duas novas figuras, no entanto, aparecem dentre as delinquentes femininas - a operária e a tecelã, profissões vinculadas principalmente aos centros urbanos.

GRÁFICO 4. DISTRIBUIÇÃO DE MULHERES ACUSADAS E/OU

CONDENADAS POR CRIMES NA CAPITAL SEGUNDO PROFISSÃO (1943)

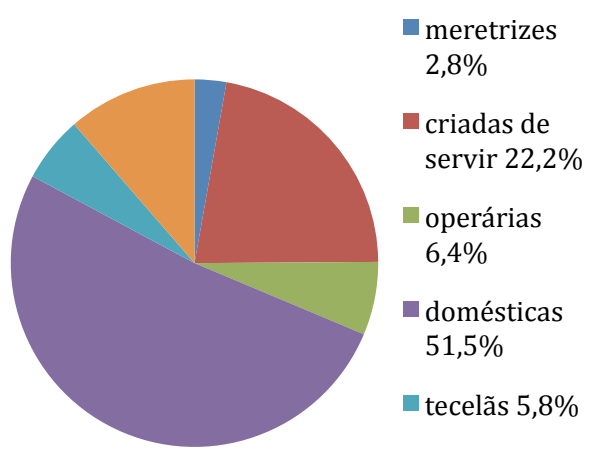

Já em relação à cor, diferentemente dos dados referentes à detenção a maioria das mulheres acusadas e/ou condenadas por crimes na capital foi declarada branca, conforme mostra o gráfico 5 .

GRÁFICO 5. DISTRIBUIÇÃO DE MULHERES ACUSADAS E/OU

CONDENADAS POR CRIMES NA CAPITAL SEGUNDO COR (1943)

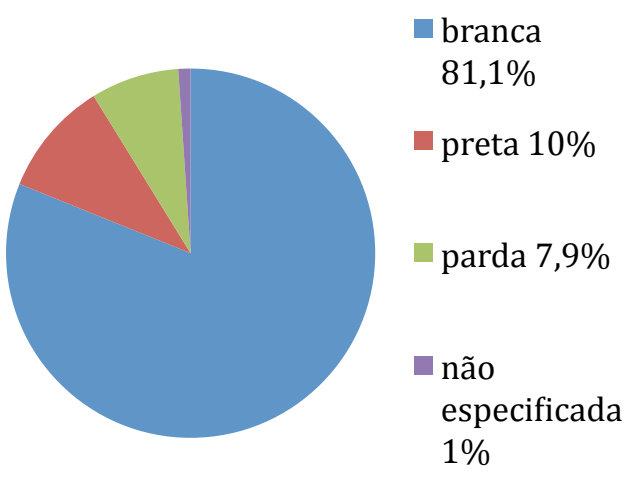


A tabela 6 expõe os tipos de prisão entre as mulheres no estado e São Paulo, na capital e no interior em 1943. Foram presas (sem contar as prisões correcionais e policiais) 26 mulheres na cidade de São Paulo e 77 no interior, enquanto, no mesmo ano, o total de homens presos na capital foi de 678 e no interior foi de 1942, reafirmando a discrepância de importância entre os sexos para o sistema criminal.

TABELA 6. DISCRIMINAÇÕES DOS TIPOS DE PRISÕES ENTRE MULHERES (1943)

\begin{tabular}{ccc}
\hline TIPO DE PRISÃO & $\begin{array}{c}\text { MULHERES NA } \\
\text { CAPITAL }\end{array}$ & $\begin{array}{c}\text { MULHERES NO } \\
\text { INTERIOR }\end{array}$ \\
\hline CONDENAÇÃO & 21 & 27 \\
FLAGRANTE & 3 & 9 \\
PREVENTIVA & 1 & 32 \\
PRONÚNCIA & 1 & 9 \\
TOTAL DE PRESAS & 26 & 77 \\
\hline
\end{tabular}

É possível afirmar que o número de pessoas presas é bem menor que o número de registrados como delinquentes. Isso se dá provavelmente pelo fato de registrados estarem respondendo ao processo em liberdade, de não terem sido processados e/ou de terem sido condenados por outras penas que não as privativas de liberdade.

O Anuário contém reflexões acerca do crime e de suas razões sociais. Atribuída principalmente aos espaços de degeneração moral, a criminalidade é retratada como sendo um problema de ordem social, bem como de ordem natural. Fruto do meio ou oriunda da própria fisiologia humana, a delinqüência deve ser combatida, e a polícia tinha um papel fundamental, de acordo com o relator nesse processo, pois a profilaxia do delito passava pelo trabalho de salvaguarda da ordem social exercido pela instituição. No entanto, o relator do Anuário atribuía os crimes e a degenerescência mais às causas sociais que propriamente a razões biológicas. Ao criticar longamente a situação social do país, a ela atribui, principalmente, os índices de criminalidade. Recrimina aqueles que exploram o povo e o altíssimo custo de vida, 
que não permite, a seu ver, a sobrevivência da população, e a leva ao cometimento de delitos, possibilitando, igualmente, a flexibilização moral e o afrouxamento dos laços. Em suas palavras:

as situações econômicas anormais, como a que atravessamos há cinco anos, têm geralmente influência sensível no aumento dos crimes. Mais do que o abuso do álcool, do que as taras e o analfabetismo, elas favorecem o progresso da moral negativa, por agravarem as dificuldades da vida, principalmente nas camadas inferiores da sociedade, onde os estados de miserabilidade são assaz comuns. Aliás, tais estados de miséria constituem uma das graves falhas da nossa organização social; possuem caráter permanente e são atenuados pela caridade pública, quando deviam, antes, ser extirpados pela reeducação, ou melhor, pela regeneração dos elementos que neles vivem por meio de higiene, alimentação adequada e do ensino primário e profissional. Um povo só será verdadeiramente forte e feliz nos casos de perfeito equilíbrio entre o custo de vida e o poder aquisitivo; não poderá haver felicidade relativa enquanto o homem for um escravo do trabalho, enquanto seus esforços não visarem mais do que o alimento para si e para os seus (EPCSP, 1944, p.195).

À criminalidade feminina, o relator igualmente atribuía a miséria social como fator preponderante. Era necessário melhorar o nível de vida da população e higienizar a classe baixa, antro da degenerescência, pois assim se evitaria a criminalidade. $\mathrm{O}$ útero sadio geraria a nação sadia, sendo este um ponto importante no qual, segundo o redator, deveriam ser investidas energias estatais. De acordo com o relatório:

pelos dados das apurações do Serviço de Estatística Policial desde 1937, conclue-se que as delinquentes pertencem em sua grande maioria às camadas inferiores da sociedade. São indivíduos de baixa formação moral, analfabetos, cheios de vícios, e trazendo muitas vezes os estigmas da degenerecência alcoólica, a gerar, por sua vez, entes que, futuramente, irão figurar destacadamente nas estatísticas policiais e criminais. Entretanto, essa criminalidade feminina e suas conseqüências são perfeitamente extirpáveis, pela melhoria do 
padrão de vida, pelo ensino obrigatório das primeiras letras e pelos cuidados higiênicos, completamente desconhecidos nos lares paupérrimos - abrigam geralmente os germens dos vícios, da prostituição e do crime (EPCSP, 1944, p. 197).

Além das prisões correcionais e policiais e da tarefa de prevenção do crime, a polícia também exercia a função de recolher, em asilos e hospitais, pessoas consideradas dementes, ação praticada tanto na capital quanto no interior, e que tinha um claro objetivo de manutenção da ordem social e de promoção da higiene mental dos recolhidos. Aqueles que se enquadravam como loucos, viciados e dementes poderiam sofrer intervenções diferentes das prisões policiais e correcionais, uma vez que, por vezes, eram levados a centros de tratamento médico, por serem considerados doentes sociais. Os dados, contidos no Anuário, relativos aos recolhimentos em asilos e manicômios mostram o número de homens e mulheres recolhidos entre os anos de 1938 a 1943, conforme pode ser verificado na tabela a seguir:

\section{TABELA 7. DISTRIBUIÇÃO DE HOMENS E MULHERES RECOLHIDOS}

EM ASILOS E MANICÔMIOS (1938 -1943)

\begin{tabular}{ccccc}
\hline ANO & $\begin{array}{c}\mathbf{N}^{\circ} \text { HOMENS } \\
\text { CAPITAL }\end{array}$ & $\begin{array}{c}\mathbf{N}^{\circ} \text { HOMENS } \\
\text { INTERIOR }\end{array}$ & $\begin{array}{c}\mathbf{N}^{\circ} \text { MULHERES } \\
\text { CAPITAL }\end{array}$ & $\begin{array}{c}\mathbf{N}^{\circ} \text { MULHERES } \\
\text { INTERIOR }\end{array}$ \\
\hline $\mathbf{1 9 3 8}$ & 489 & ----------- & 294 & ------------- \\
$\mathbf{1 9 3 9}$ & 428 & 1604 & 222 & 688 \\
$\mathbf{1 9 4 0}$ & 655 & 1380 & 259 & 527 \\
$\mathbf{1 9 4 1}$ & 518 & 1153 & 219 & 387 \\
$\mathbf{1 9 4 2}$ & 598 & 927 & 228 & 365 \\
$\mathbf{1 9 4 3}$ & 516 & 996 & 247 & 454 \\
\hline
\end{tabular}

A possibilidade de recolhimento em manicômio judiciário, por meio da aplicação de medida de segurança, era prevista tanto na lei das Contravenções Penais, de 1941, quanto no Código Penal ${ }^{60}$. Para tanto, era necessário que fosse com-

60 Conforme artigo 13 e seguintes da Lei das Contravenções Penais e 75 e seguintes do Código Penal. 
provada a periculosidade do agente do crime ou da contravenção, sendo considerados perigosos, dentre outros, os reincidentes, aqueles com doença mental e reduzida capacidade de discernimento, o reincidente em casos de mendicância e vadiagem, o reincidente em prática de jogos de azar e aqueles condenados por crimes cometidos em estado de embriaguez. O recolhimento deveria se dar em momento posterior ao cometimento do delito ou contravenção. Os degenerados mereciam o isolamento asilar, estando, dentre eles, os ébrios, os vadios, os mendigos e os viciados em geral.

A associação do alcoolismo à degenerescência era uma constante nas décadas de 1930 e 1940. Fruto do pensamento higienista, a necessidade de combate ao vício tornara-se uma questão de saúde pública que deveria urgentemente ser controlada e resolvida. A historiadora Maria Clementina Pereira Cunha, em pesquisa sobre a história do Asilo Juqueri, em São Paulo, ressalta que a preocupação com o alcoolismo ia além da ordem médica, uma vez que se julgava que os alcoólatras rendiam menos no trabalho e estavam mais expostos a acidentes de trabalho, sendo um "mal coletivo" que atingia o operariado, aproximando-o da criminalidade, do ócio e da vadiagem (CUNHA, 1988, pp. 196 e 197). Nesse cenário o lugar privilegiado de internação dos viciados e degenerados era aquele que não só o retirava do seio social, mas que tinha uma proposta de intervenção terapêutica.

Espaço destinado à regeneração e cura, o asilo do Juqueri, por exemplo, era referência, desde o início do século XX, de local de tratamento de desviantes. De acordo com Cunha:

joio no meio do trigo social, estes indivíduos nocivos são, no entanto, na maioria das vezes, intocáveis pelas malhas da polícia ou da justiça em seus comportamentos nem sempre criminalizáveis. Necessário assim, para a "defesa da sociedade", definir para os mesmos uma instância legal e legitimada de exclusão e controle: a medicina mental se encarrega de ocupar esse espaço (CUNHA, 1988, p. 112).

As classes perigosas, aqueles em desacordo com os papéis sociais deles esperados, os que causavam transtornos na ordem da cidade tinham como possíveis 
destinos o cárcere, as casas de correção e/ou os manicômios e asilos. Relegados aos últimos, os considerados degenerados sociais eram encaminhados para longe do convívio social. De acordo com Cunha:

ao lado dos negros outros setores da população perdem, na cidade que cresce e altera as rotinas da vida cotidiana, os seus espaços tradicionais. Setores improdutivos, como a velhice e os menores, certo tipo de doentes, débeis mentais, deficientes de várias qualidades terão reinventado o seu lugar. $\mathrm{Na}$ cidade eles tenderão a deixar de ser uma questão que afeta ao grupo familiar ou social mais diretamente concernido, para constituírem um problema efetivo para a administração pública. Alguns desses setores encontrarão no hospício, ao lado dos loucos, o seu definitivo 'lugar de repouso' (CUNHA, 1988, pp. 31 e 32).

Apesar de Cunha tratar especificamente do início do século XX, a prática de recolhimento daqueles considerados dementes continuava em voga nos anos de 1940 e era considerada importante pelos responsáveis pela ordem pública. O posicionamento do relator do Anuário em relação ao "problema da demência" evidencia uma preocupação antes profilática que repressiva, uma vez que, em suas palavras tal problema:

(...) é sem dúvida consequência da pobreza, responsável pelo analfabetismo, pela alimentação deficiente, pelo abuso do álcool e por outros vícios, em que milhares de desgraçados se afogam, para esquecer, provavelmente, a sua impossibilidade de reação. Assim, se é importante a construção de manicômios ou a ampliação dos já existentes, mais importa ainda dar a esses infelizes meios para fugir às suas atuais condiçôes de vida, evitar que os filhos deles encontrem as mesmas dificuldades e as mesmas misérias, preservando-se, desse modo, as geraçôes futuras dos estigmas da degenerescência alcoólica, das conseqüências terríveis da sifilis. Certo, o problema é bem complexo, pois exige, antes de tudo, um equilíbrio real entre o poder aquisitivo do povo e o custo de vida, mas também não é menos verdade que esse equilíbrio viria, por outro lado, facilitar o progresso do país, além de concorrer para a diminuição do crime e de outras manifestações moralmente negativas, como o suicídio (EPCSP, 1942, p. 75). 
No que se refere às mulheres dementes o relator apontava o menor número de recolhidas, quando comparadas aos homens, fato que justificava como sendo “(...) natural, pois a mulher, mesmo nas classes mais humildes da sociedade, leva uma vida mais higiênica ou menos viciosa que os homens, que, nesse setor social se destacam sobremaneira em todas as modalidades de vícios, muito especialmente no abuso do álcool e da bebida" (EPCSP, 1944, p. 87). Assim, as degeneradas representavam as desviantes no universo de suspeitos que compunham a classe baixa. Àquelas que não levavam a vida higiênica que delas era esperada, eram atribuídos os estigmas da demência e da alienação, e receitadas as internações asilares.

Além dos dados apresentados pelos anuários do Serviço de Estatística Policial do Estado de São Paulo, para que seja possível identificar quais os principais motivos de encarceramento feminino à época da criação e nos primeiros anos dos presídios femininos optou-se por analisar os dados apresentados por Hilda Macedo, assistente da cadeira de Introdução à Criminologia da Escola de Polícia, que em 1953 publicou no periódico Arquivos da Sociedade de Medicina Legal e Criminologia de São Paulo artigo denominado Criminalidade Feminina e sua Prevenção, no qual busca responder quem e como eram as delinqüentes no período. Fruto de uma aula ministrada pela autora na disciplina "Higiene mental e profilaxia criminal", seu artigo contém números que permitem não só traçar um mapa do aprisionamento de mulheres na cidade de São Paulo e um perfil social das encarceradas no período, como também apontar quais dados interessaram à pesquisadora, ou seja, o que era importante apontar em uma pesquisa sobre encarceramento feminino, de modo que os números se tornassem fundamentos de uma argumentação.

Os dados coletados mostram que havia um total de 179 mulheres presas em 1953 nos estabelecimentos prisionais da cidade, sendo que apenas em um deles, a Penitenciária do Carandiru, havia um prédio específico para o encarceramen- 
to feminino, que era a Penitenciária de Mulheres institucionalizada em 1941. Nessa casa havia um total de trinta presas, pois não existiam acomodações para abrigar mais mulheres. Na Casa de Correção estavam recolhidas, dentre sentenciadas e processadas, sessenta mulheres, e no Presídio do Hipódromo, oitenta e nove mulheres (MACEDO, 1953, p. 287).

Das presas que se encontravam no Presídio de Mulheres, apenas uma delas, condenada por crime de violação de privilégio de invenção e apropriação indébita, havia concluído o ensino secundário, dado que, de acordo com Macedo, é relevante, pois explica a complexidade do crime cometido, que exigia "um preparo". As demais vinte e nove mulheres lá estavam por crimes de furto, roubo, homicídio, lesões corporais, infanticídio e incêndio, sendo todas, segundo a autora, provenientes de meio social baixo, sem instrução ou apenas com a educação primária. Em relação à profissão, a pesquisa mostra que todas as vinte e nove eram empregadas domésticas. Destas, ainda, ressalta que nove delas eram reincidentes específicas por crime contra o patrimônio, ou seja, cometeram mais de uma vez um crime desse tipo, e apenas uma reincidente genérica, ou seja, cometeu ao menos dois crimes diferentes, sendo eles roubo e ferimentos leves (MACEDO, 1953, p. 287).

Em relação ao estado civil, vinte delas, ou seja, dois terços eram solteiras. Dentre as solteiras a pesquisa aponta que ao menos quinze "foram desviadas" antes dos 18 anos. Das restantes, sete eram casadas e uma viúva, que o era por ter matado seu marido. Além disso, a autora salienta que algumas apresentavam doenças como sífilis, que além da transmissão venérea permite outros tipos de contágio, como o congênito. Outras foram consideradas portadoras de "tendências toxicófilas", ou seja, com propensão ao uso de drogas. Por fim, aponta que cinco tiveram passagem, em algum momento de suas vidas, pelo asilo de menores (MACEDO, P. 287).

No tangente à Casa de Correção, das sessenta presas, quarenta lá estavam por crime de furto, três por assalto, seis por homicídio, quatro por ferimentos graves e leves, uma por abortamento, quatro por estelionato, uma por adulteração de cédulas e uma por venda de entorpecentes. A maioria, ou seja, quarenta e sete delas, era empregada doméstica; quatro eram donas de casa; uma era costureira; e uma 
exercia cargo de funcionária pública (MACEDO,1953, p. 287). Por fim, os dados apontam que oitenta e nove mulheres estavam no Presídio do Hipódromo por falta de espaço na Casa de Correção. Destas, setenta e cinco mulheres lá estavam por poucos dias para aplicação de medidas corretivas, por terem praticado contravenção penal. As contraventoras eram "vadias nas quais se incluem mendigas, prostitutas e alcoólatras" (MACEDO, 1953, p. 287).

Pelos dados apresentados por Macedo é possível concluir que as mulheres presas na cidade de São Paulo no ano de 1953 o estavam, principalmente, por crimes contra o patrimônio; contravenções penais, especialmente vadiagem; crimes contra a vida, em especial homicídio, infanticídio e aborto. Em relação às profissões, grande parte exercia trabalhos fora de casa, principalmente, como empregadas domésticas. Informações sobre estado civil, apenas consideradas as da penitenciária de mulheres, mostram que a maioria delas era solteira. Tais informações, em especial quando cruzadas com os dados sobre trabalho e crimes cometidos, apontam para a criminalização de mulheres de classe baixa, que provavelmente estavam mais vulneráveis à intervenção penal que as demais.

Tanto os dados apresentados pelos anuários, quanto por Macedo, denotam uma associação entre os "espaços sociais do desvio" e as condutas consideradas crime ou contravenção. Em especial a vinculação entre mulheres e condutas ilícitas voltava-se àquelas que não correspondiam ao estereótipo do sexo frágil. Possivelmente as principais vítimas do sistema de justiça criminal eram aquelas que estavam mais expostas aos seus olhares e que destoavam na paisagem da cidade moderna.

\section{REGISTROS E TIPOLOGIAS}

Fotografias das primeiras presidiárias do Presídio de Mulheres de São Paulo, encontradas nos arquivos do Museu Penitenciário Paulista durante a coleta de materiais para a presente pesquisa, retratam traços sociais que aparecem nos anuários estatísticos: há uma continuidade entre os tipos sociais identificados nos anuários e aqueles presentes nos álbuns que contém fotografias de identificação criminal das 
mulheres presas. Mulheres imigrantes, negras e pardas, em sua maioria jovens, compõem o universo das 52 fotografadas registradas nos álbuns encontrados. Não há, além das fotografias, e de poucas informações dos funcionários do Museu outros registros que as expliquem. Sabe-se que são álbuns oriundos do Presidio de Mulheres, instalada em 1941 nos terrenos da Penitenciária do Estado. A disposição das fotografias, a maneira como as fotografadas se apresentam, os uniformes que usam e outros detalhes, como o número atrelado a suas roupas, permitem concluir que são registros das primeiras mulheres presas daquele estabelecimento.

Em geral os registros aparecem da seguinte maneira nos álbuns: quatro fotografias de cada uma das mulheres, sendo as duas primeiras de frente e perfil com roupas próprias e as duas seguintes de frente e perfil com o uniforme da penitenciária. Nas duas fotografias de perfil aparece um número identificatório atrelado à roupa, ou desenhado na fotografia. Estes números são específicos para cada uma das mulheres, ou seja, não se repetem, e vão do número dois ao número 60 , com algumas lacunas. Em geral as fotografias dispostas nos álbuns respeitam a ordem numérica. O número possivelmente corresponde ao número de registro institucional de cada uma delas. 
FOTOGRAFIAS DE IDENTIFICAÇÃO CRIMINAL DO PRESÍDIO DE MULHERES

DE SÃO PAULO
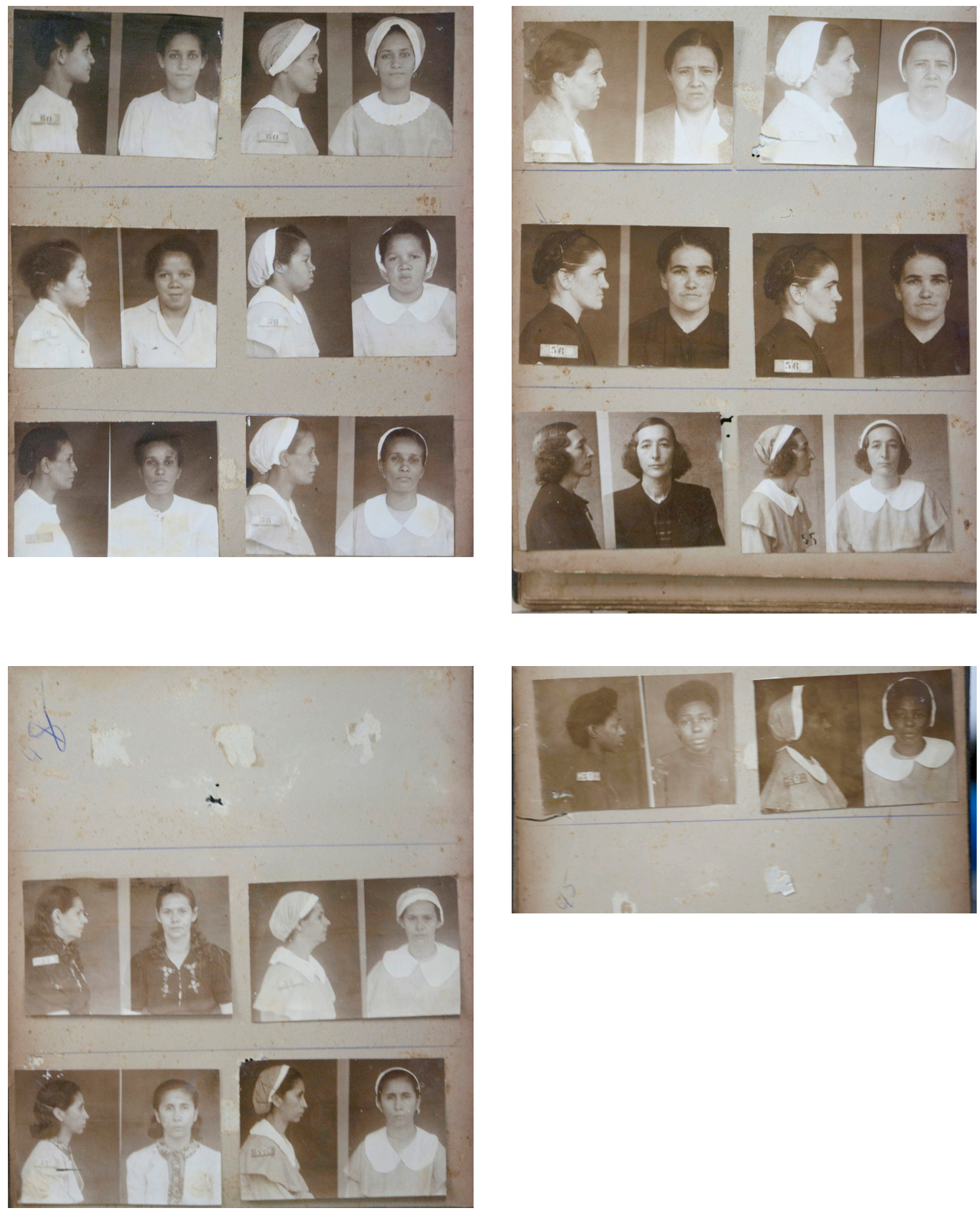
FOTOGRAFIAS DE IDENTIFICAÇÃO CRIMINAL DO PRESÍDIO DE MULHERES

DE SÃO PAULO
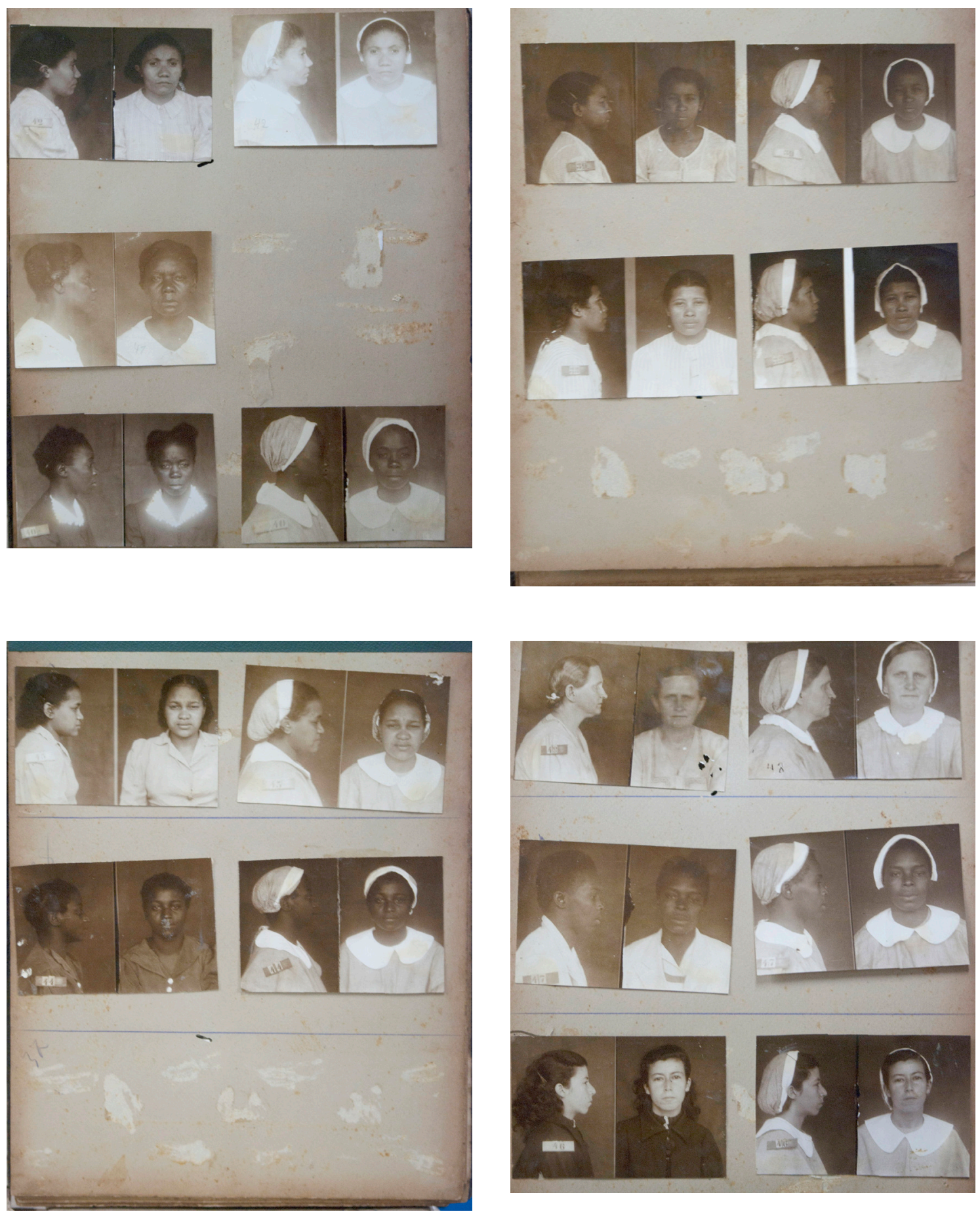
FOTOGRAFIAS DE IDENTIFICAÇÃO CRIMINAL DO PRESÍDIO DE MULHERES

DE SÃO PAULO
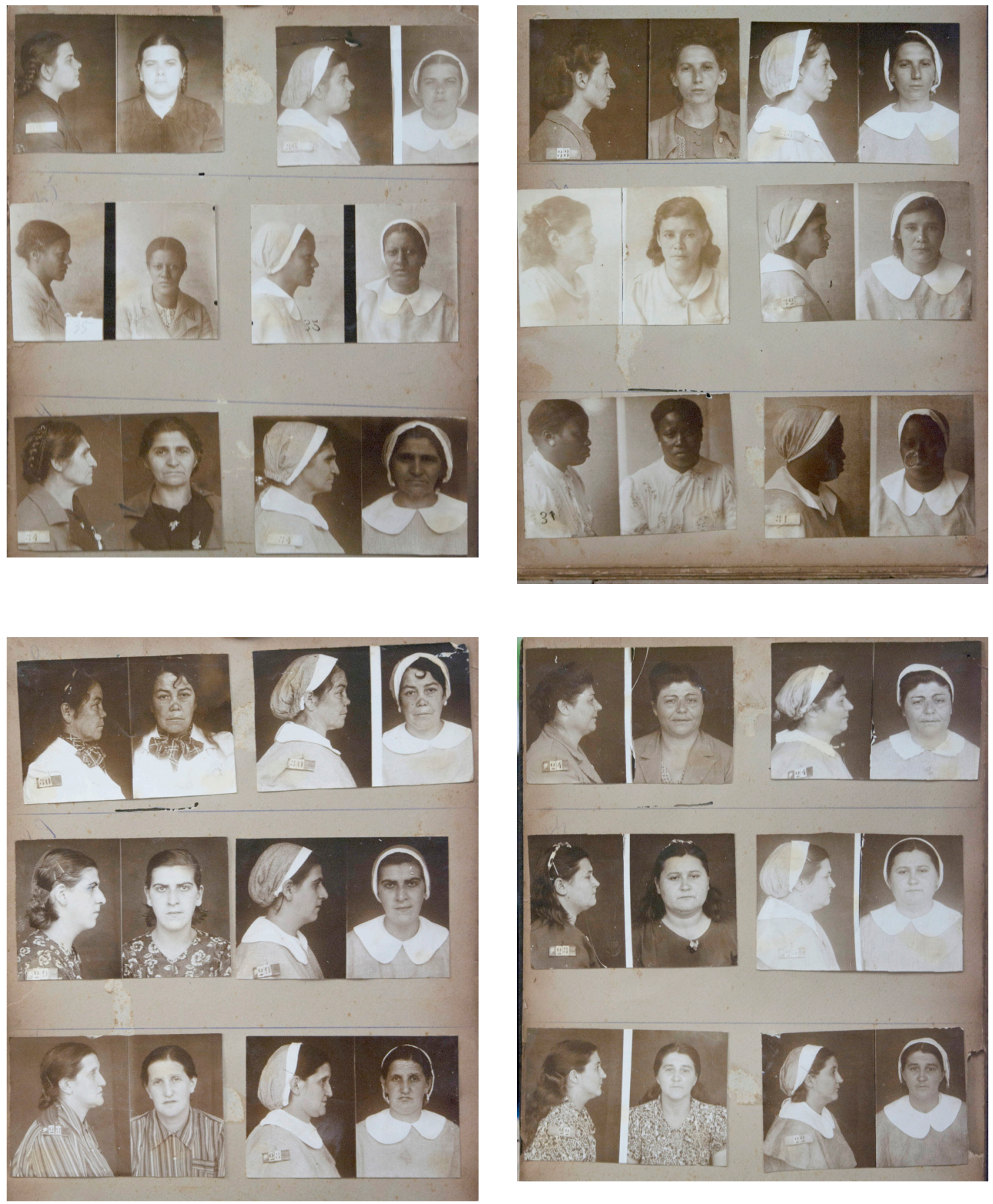
FOTOGRAFIAS DE IDENTIFICAÇÃO CRIMINAL DO PRESÍDIO DE MULHERES

DE SÃO PAULO
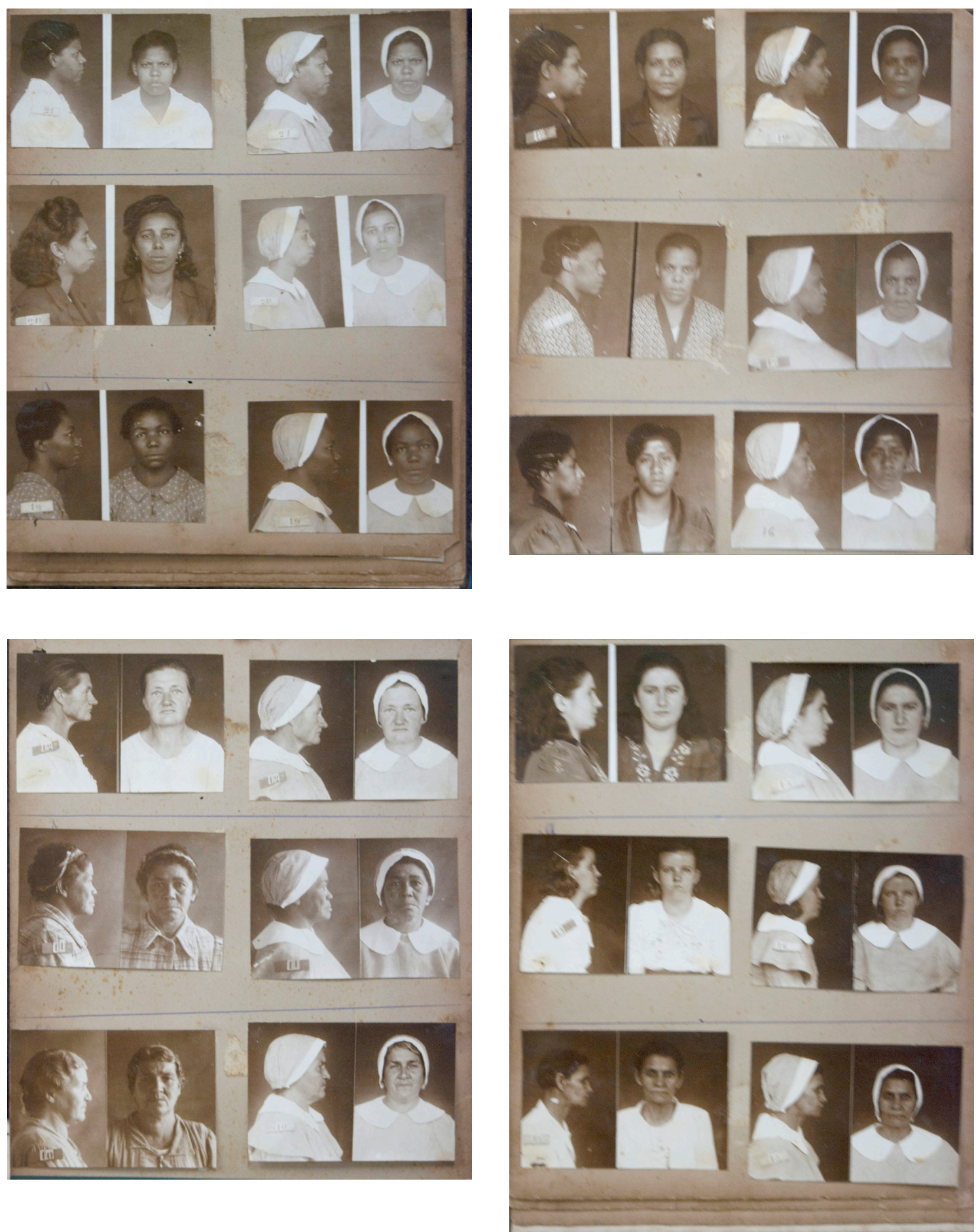
FOTOGRAFIAS DE IDENTIFICAÇÃO CRIMINAL DO PRESÍDIO DE MULHERES

DE SÃO PAULO
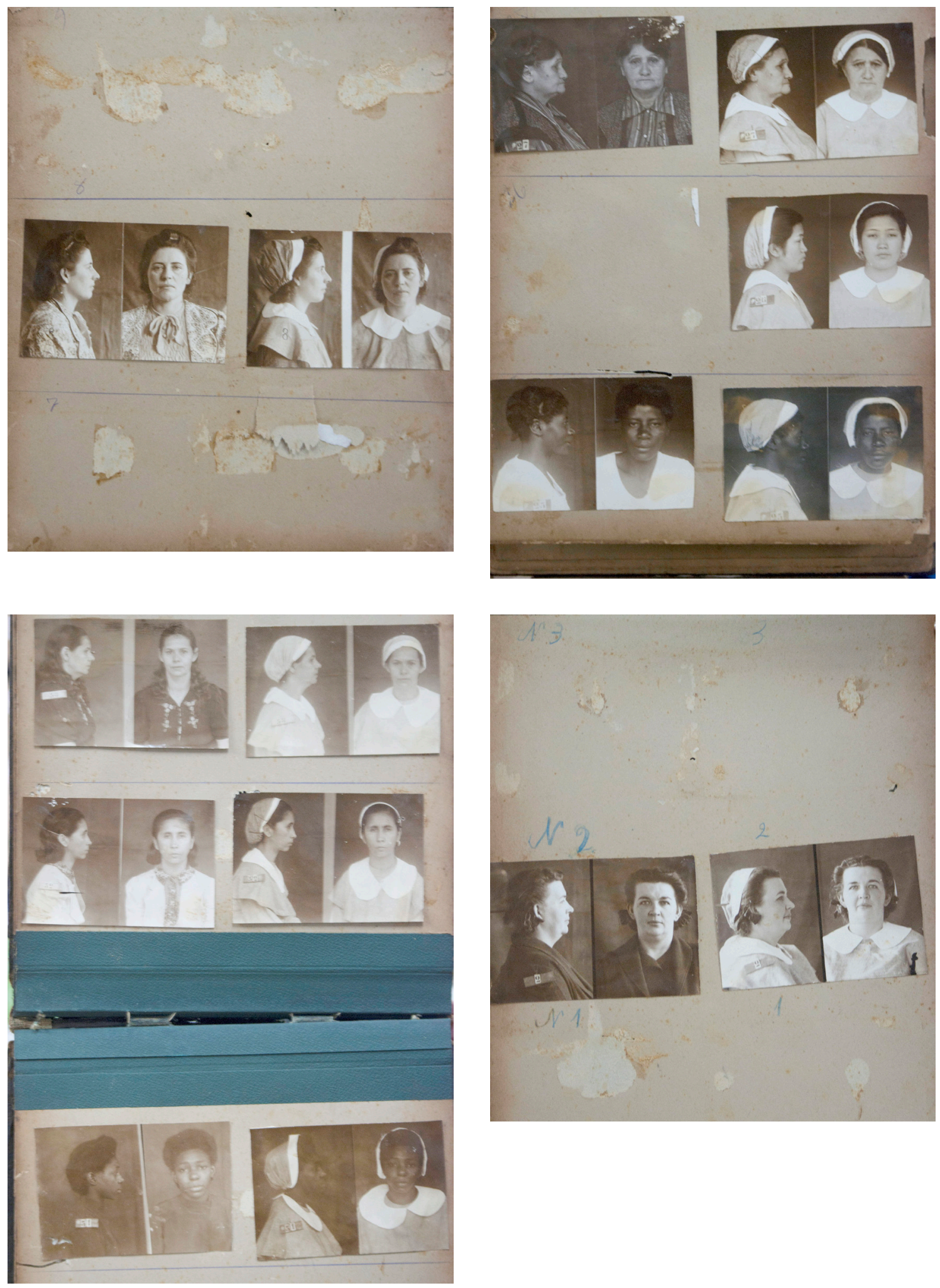
Desenvolvido pelo antropólogo e criminólogo francês Alphonse Bertillon, em 1879, o método de registro criminal, que envolvia a fotografia de frente e perfil, medidas antropométricas dos suspeitos ou condenados e maneiras específicas de arquivar essas medidas - o Bertillonage, como ficou conhecido - foi utilizado pela polícia brasileira a partir dos últimos anos do século XIX de modo a fichar aqueles que passavam pelas delegacias, buscando mapear os tipos criminosos, facilitar as investigações e evitar a reincidência. Bertillon propunha produzir um "mapa da pessoa" submetida à averiguação. De acordo com a antropóloga Olívia Maria Gomes da Cunha, o método de Bertillon e o datiloscópico, de análise de impressões digitais, criado pelo argentino Juan Vucetich, eram utilizados no Brasil no início do século XX. Há notícias da utilização desses métodos na identificação de mulheres presas na casa de detenção do Rio de Janeiro em 1906, ano em que houve um grande debate em torno da utilização da fotografia e da antropometria como método de identificação criminal (Cunha, 2002, p. 17). Segundo Cunha, até 1906:

todos os presos identificados deveriam ser fotografados de frente e perfil. E seriam esses rostos, faces compungidas e olhares cabisbaixos, de um indisfarçado constrangimento, que a partir da popularização do uso da fotografia judiciária passariam a fazer parte das colunas policiais dos vários jornais da cidade, embora a legislação prescrevesse o caráter sigiloso de tal prática (CUNHA, 2002, p. 18).

Para alguns atores do cenário político-jurídico nacional, como o senador Barata Ribeiro, o método de Bertillon era inadequado, pois expunha os presos a situações embaraçosas, como as medidas antropométricas, além de considerar os registros fotográficos uma invasão, pela sua inadequada veiculação na mídia, bem como pelo próprio registro. De acordo com Cunha

a fotografia judiciária povoaria um território cujo contato seria capaz de contaminar a imagem da pessoa, transformando-se no que Barata Ribeiro chamou de 'estigma da de- 
sonra'. A desonra resultaria da transposição das fronteiras de uma memória, cujo domínio era privativo, contaminando o corpo de um cidadão. (CUNHA, 2002, p.20).

Sobre as imagens de frente e perfil, o especialista em fotografia forense Archibald Rudolph Reiss advertia, segundo Cunha, que "porque tinham total consciência da sua condição de incriminados, os fotografados faziam tudo para dar a esses retratos um ar diferente daquele que se imaginava possuir um criminoso". Era importante, de acordo com o especialista, que as fotos fossem o mais natural possível (CUNHA, 2002, p. 24). Não é possível dizer até que ponto que no dia a dia penitenciário brasileiro as instruções de Archibald Rudolph Reiss e Bertillon eram seguidas, mas a detida análise das fotografias presentes nos álbuns do Presídio de Mulheres de São Paulo permite identificar algumas constantes nas expressões e posturas das fotografadas: corpo ereto, olhar direto para a lente, seriedade expressa nos lábios. Algumas, no entanto, subvertem a seriedade. As presas de número 2, 59 e 60 esboçam sorrisos, rompendo com a neutralidade possivelmente almejada pelo fotógrafo. A advertência de Archibald Rudolph Reiss parece fazer sentido.

Ainda, as fotografias permitem verificar a despersonalização provocada pelos uniformes, uma vez que a maioria das séries contém registros das mesmas mulheres com roupas pessoais e com as vestimentas institucionais. Os enfeites das roupas e dos cabelos desaparecem no padronizado uniforme, que lembra os hábitos simples e largos de algumas congregações religiosas. $\mathrm{O}$ pano que cobre a cabeça não só despersonaliza, pois encobre as particularidades dos cabelos, mas imprime às fotografadas ares de subserviência.

Tanto a ordem numérica, quanto a disposição nos álbuns e a identicidade dos uniformes permitem concluir que estas mulheres foram presas em um período semelhante, e que, durante um tempo, possivelmente cumpriram pena conjuntamente, formando o universo carcerário do Presídio de Mulheres de São Paulo nos seus primeiros tempos. É possível identificar, dentre as fotografadas, uma alta porcentagem de mulheres pretas e pardas - aproximadamente 50\% do total -, bem como de 
imigrantes, considerando "fenótipos" germânicos, ibéricos, asiáticos e mediterrâneos - registros que dialogam com as estatísticas do período.

O exame desses dados permite levantar algumas hipóteses sobre o perfil das mulheres aprisionadas no período pesquisado, em especial a vinculação entre os desvios do "dever ser" feminino e a criminalidade. No entanto, nas análises de penitenciaristas e estudiosos da época é possível encontrar argumentos que justificam a perseguição a determinado perfil, bem como a necessidade de criminalizar grupos específicos de mulheres. Os estereótipos da criminosa presentes em textos e falas de especialistas do período auxiliam na delineação da figura da mulher criminosa nesses primórdios dos estabelecimentos prisionais femininos do país. Para que seja possível identificar e entender a função atribuída pelos seus idealizadores aos cárceres para mulheres, é mister, antes, pontuar a quem esses estabelecimentos deveria servir. Algumas questões nesse sentido serão trabalhadas no próximo capítulo. 


\section{Capitulo Três}

\section{CLASSIFICANDO A "MULHER DELINQUENTE"}

que é o delito? Que é o crime? Sua definição está condicionada ao tempo e ao espaço. Dentro de um mesmo aglomerado humano, existe uma evolução no plano da sua concepção. Fatos que há um século e meio se achavam completamente deslembrados do Código Penal, das leis punitivas, dos regulamentos, das contravençôes, podem passar a figurar, mais tarde em artigos dos códigos. (...) a simples circunstância de local, para o mesmo fato, determina a existência de delito, de crime, de contravenção, passiveis de punição criminal. AEPCSP, 1944, p. 94

Partindo do pressuposto de que crimes são condutas consideradas socialmente negativas bem como situações conflituosas em determinado tempo e espaço, pode-se considerar relativo o conceito de crime, uma vez que adquire diferentes características em culturas, épocas e locais diversos. Não existe uma realidade ontológica do crime, ou seja, ele não existe naturalmente e por si só. Trata-se de um ato ao qual é conferido contextualmente um significado. Transgressóes às regras e leis e a 
não observância de condutas socialmente prescritas em relação a tabus e a interdições só podem ser reprimidas em contextos nos quais tais interdições foram criadas, não havendo, portanto, uma universalidade de condutas delituosas. São inúmeros os exemplos etnográficos da relatividade do conceito de crime e de como só é possível compreender as suas delineações de maneira relacional ${ }^{61}$.

Crime é uma conduta estabelecida por lei, e, na sociedade brasileira, por leis escritas. O próprio Código Penal de 1940 prevê a anterioridade da lei para a estipulação de uma conduta delitiva, ou seja, ressalta que "não há crime sem lei anterior que o defina". Se espelho da sociedade e/ou se modelo para a sociedade, a lei penal exerce um papel de enquadramento de condutas consideradas intoleráveis, que atentam contra determinados bens escolhidos para terem a proteção penal. Há, portanto, uma seleção prévia de quais são esses bens e quais atentados a eles são considerados transgressões. Vida, patrimônio, costumes, honra, saúde pública, entre outros, são bens tutelados na esfera penal, e determinadas afrontas a eles recebem o nome de "crime".

Durkheim, em meados do século XIX, já havia alertado para a necessidade de uma avaliação social e contextual do crime que o distanciasse de uma perspectiva naturalizada. Apesar do reconhecimento da generalidade dos atos criminosos, ou seja, da existência, em todas as comunidades humanas, de "atos que ofendem certos sentimentos coletivos dotados de energia e nitidez particulares" (DURKHEIM, 1963:62), chamando para si a repressão penal, havia uma extensa variação da qualificação sobre quais atos adquiriam estas características. A generalidade do fenômeno criminal, definida por Durkheim (1963, p. 60) como expressão da sua normalidade social, não deve ser confundida, assim, com a sua naturalização.

61 A literatura etnográfica e etnológica acerca do crime é extremamente ilustrativa dessa característica não ontológica do delito, uma vez que permite a constatação de que aquilo que é considerado crime em determinada sociedade não o é em outra. Um exemplo de descrição etnográfica que aborda a temática está presente na obra Crime e Costume na Sociedade Selvagem, de Malinowski. O antropólogo Robert Weaver Shirley (Shirley, 1987, pp. 12 e 13) cita exemplo etnográfico, coletado e narrado pelo antropólogo Knud Rasmussen, em 1929, entre os esquimós (Innuit) da Groenlândia. Trata-se do incentivo à morte de pessoas mais velhas no inverno, quando não há alimento para todos os membros do grupo. O que seria considerado pela legislação brasileira homicídio, ou instigação ao suicídio, era, entre eles, prática não só aceita como estimulada. 
A normalidade dos atos sociais está inscrita no tipo médio que é próprio a cada agrupamento social e "não pode ser definida in abstrato e nem de maneira absoluta" (DURKHEIM, 1963, p. 52). A noção de crime, por essa regra, não poderia ser definida fora da própria sociedade em foco. A caracterização destes atos se daria pelo choque entre o que Durkheim chama de "consciência moral da sociedade" e a diversidade de consciências individuais construídas a partir de referências ao meio social e às influências hereditárias, entre outras. No âmbito destas divergências se encubariam os atos criminosos, cuja determinação não poderia advir de uma característica intrínseca e sim da importância a eles atribuída pela "consciência coletiva" de determinada sociedade em espaço e tempo definidos.

A partir destas avaliações, o criminoso não deveria ser mais visto como um ser totalmente insociável e parasitário ou mesmo como um corpo estranho e inadmissível no ambiente social. Ao contrário, visto como um dado regular da vida em comunidade e não como uma doença, a compreensão sobre o crime e sobre o seu tratamento deveria ser repensada. Durkheim chega a afirmar que o crime tem uma importante função social ao indicar certa maleabilidade dos "sentimentos coletivos" e, por vezes, sinalizar suas transformações, antecipando "a moral que está por vir", prenunciando mudanças necessárias às sociedades (DURKHEIM, 1963, 65).

Já segundo o antropólogo Robert Weaver Shirley, um axioma fundamental da antropologia legal é o de que as normas são criadas em bases sociais e econômicas e precisam ser observadas em seu conteúdo social (SHIRLEY, 1987, p. 12). Assim, as regras são frutos de contextos específicos e, para que possam ser compreendidas, devem ser analisadas à luz desses contextos. As leis que estipulam quais condutas são, para determinada sociedade, consideradas delitos, refletem bens e valores essenciais a essa sociedade.

Não só há, em todos os agrupamentos humanos, padrões esperados de comportamento, como também previsões de sanções em casos de ruptura com esses padrões. O antropólogo Paul Bohannan frisa que "são esses três atos sociais, um após o outro, que criam a conduta legal de qualquer sociedade: primeiro a quebra do padrão; a seguir, a reação, e, finalmente, a correção" (BOHANNAN, 1966, p. 
170). Nesse sentido o "dever ser" seria pautado pelo "não dever ser" e vice versa, havendo um binarismo de condutas aceitas e não aceitas que possibilita a existência dos padrões de comportamentos e das rupturas com esses padrões. Os modelos de comportamento, os atos considerados rupturas com esses modelos, as reações possíveis quando há rompimentos e as correções prescritas aos agentes da ação variam de sociedade para sociedade. A lembrança de Bohannan de um provérbio do povo Gola, habitante do interior da Libéria, de que "a lei é como um camaleão - muda de forma em cada lugar e só pode ser controlada pelos que conhecem seus costumes" é oportuna para ilustrar a relatividade do conceito de lei (BOHANNAN, 1966, p.165).

Uma vez considerada a não ontologia da lei, pode-se, por analogia, aplicar o mesmo raciocínio às ações que compõem o "crime", pois estas são definidas por um aparato legal erguido de acordo com os valores morais e sociais de determinada sociedade. Se o conteúdo da lei e o que é crime não são categorias universais, o mesmo pode ser dito da categoria "mulher criminosa" uma vez que a criminosa não existe somente a partir do momento em que é julgada e condenada, mas existe antes disso, quando há uma delineação de quem pode ser considerada delinquente, de quais são as atitudes, os espaços, os lugares próprios da delinquência. Há uma seleção prévia do sistema penal que além de apontar condutas consideradas crimes, igualmente aponta quem são os sujeitos privilegiados do delito.

Assim como as categorias de crime não são dados que se encontram na "natureza”, universais e inquestionáveis, as de criminosas também não o são. Pelo contrário, são construtos sociais elaborados de maneira relacional, sendo importante questionar não apenas quais são os padrões esperados e os desvios intoleráveis, mas quem são considerados os possíveis agentes desses desvios. Há uma associação entre delinquência e estilos de vida, classe social, tipos de trabalho, localização espacial dos sujeitos nas cidades, dentre outros. Foucault, em Vigiar e Punir - história da violência nas prisões -, chama a atenção para essa seletividade prévia do indivíduo delinquente dentre os pertencentes às classes baixas. Em suas palavras 
não há natureza criminosa, mas jogos de forças que, segundo a classe a que pertencem os indivíduos, os conduzirão ao poder ou à prisão: pobres, os magistrados de hoje sem dúvida povoariam os campos de trabalhos forçados; e os bem nascidos 'tomariam assento nos tribunais e aí distribuiriam justiça' (FOUCAULT, 2004, p. 240).

De acordo com Bohannan a matéria prima do antropólogo do direito são os padrões e as ações que com eles rompem, sendo sua função investigar “(...) os axiomas éticos que estão por trás desses padrões, concentrando sua atenção, ao mesmo tempo, mais nas instituições de reação do que na lei, ou padrão, em si próprio" (BOHANNAN, 1966, p. 170). Mapear quem são os sujeitos principais a quem está destinado o aparato legal de reação ao crime, ou seja, quem é o agente privilegiado da ruptura com o padrão, permite compreender como as instituições de reação enxergam e criam o agente do delito.

Sendo assim, a seguir, será analisada a delineação das categorias "mulheres criminosas" no Brasil, naquele momento específico do surgimento dos primeiros estabelecimentos prisionais para mulheres. Como a mulher criminosa é pensada? É possível identificar quem era ela, ou seja, apontar a que classe, a que raça/cor, a que grupo social pertencia? Qual o modelo de criminosa desenhado no Brasil? Será que os penitenciaristas tinham modelos de criminosas em mente? Se sim, esses modelos correspondiam aos estereótipos de criminosas delimitados por grandes teorias criminológicas? As criminosas são sempre as protagonistas de desvios de um determinado modelo feminino? É possível que mulheres-padrão sejam enquadradas em categorias de criminosas?

\section{DIÁLOGO COM A}

\section{ANTROPOLOGIA CRIMINAL}

Antes de iniciar a análise das categorias de criminosas encontradas nas apreciações de penitenciaristas e estudiosos da criminologia no período pesquisado, faz-se necessário explicitar a opção teórico/metodológica de colocá-las em diálogo com 
a obra La Donna Delinquente, la Prostituta e la Donna Normale, do médico italiano Cesare Lombroso. Isso porque são muitas as associações entre os estereótipos criminais femininos traçados no país, à época e nos anos seguintes da criação dos primeiros presídios femininos, e as definições da "mulher normal", da "prostituta" e da "mulher delinquente" delineadas por Cesare Lombroso e Guglielmo Ferrero ${ }^{62}$ na obra escrita em 1893.

Nicole Hahn Rafter, criminóloga, e Mary Gibson, historiadora, tradutoras da obra de Lombroso para o inglês, em prefácio escrito em 2004 à tradução inglesa de La Donna Delinquente, la Prostituta e la Donna Normale, ressaltam que "esta obra, mais que qualquer outra na história ocidental, determinou direções seguidas nos estudos do crime feminino", talvez por ter sido a principal referência sobre criminalidade e mulheres em um período de mais de 50 anos, tendo tido muito mais influência nos estudos sobre mulheres delinquentes que sua obra L'Uomo Delinquente nas análises sobre a criminalidade masculina ${ }^{63}(2004$, p. 3). Foi o primeiro livro de Lombroso traduzido para o inglês, tendo sido o primeiro contato de muitos pensadores com o trabalho do criminólogo italiano, e com os ensinamentos da Antropologia Criminal ${ }^{64}$.

Esta observação das tradutoras é ratificado por Carol Smart, socióloga que publicou, no final da década de 1970, Woman, Crime and Criminology, um dos primeiros trabalhos sobre mulheres e criminalidade em uma perspectiva feminista. Smart realça a influência da obra de Lombroso nos estudos posteriores sobre criminalidade feminina ${ }^{65}$, todos marcados por um determinismo biológico pautado na

62 Segundo Gibson e Rafter, muito provavelmente a contribuição de Ferrero para a obra foi de um graduando, muito mais que de um co-autor. (2004, p. 33) Por esse motivo, ao pontuar as principais conclusões do estudo citam Lombroso e não Ferrero.

63 A teoria lombrosiana do criminoso nato foi bastante criticada, dentre outros momentos, no $2^{\circ}$ congresso de Antropologia Criminal de Paris, em 1889. Essas e outras críticas, segundo Gibson e Rafter, justificam, possivelmente, o tom defensivo utilizado pelo autor em La Donna Delinquente, la Prostituta e la Donna Normale (2004, p. 12).

64 Vale ressaltar, no entanto, que a primeira tradução feita para o inglês, em 1895, cujo título ficou The Female Offender, omitiu inúmeras partes do original, dentre elas, partes que tratavam de lesbianismo, ciclo menstrual e relação entre esses e a criminosa (Gibson e Rafter, 2004, p. 4)

65 Smart cita as obras de Lombroso e Ferrero (1895), W. I. Thomas (1923), e Otto Pollak (1950) como sendo estudos pioneiros sobre criminalidade feminina (SMART, 1976, p. 27). Gibson e Rafter citam também a 
"natureza feminina", conceito culturalmente construído que aparece como dado inquestionável nos trabalhos sobre o tema (SMART, 1976, pp. 27 a 30). Igualmente a socióloga Julita Lemgruber, autora do primeiro trabalho sobre criminalidade feminina nas ciências sociais brasileiras, escrito na década de 1970, ressalta a presença da perspectiva lombrosiana nas análises sobre o tema na primeira metade do século XX (LEMGRUBER, 1999, pp. 2 e 3).

La Donna Delinquente, la Prostituta e la Donna Normale permitiu uma associação direta entre a sexualidade feminina, a loucura e o crime ${ }^{66}$ (GIBSON e RAFTER 2004, p. 4). Escrita à época do surgimento da sexologia, Lombroso buscou conciliar as patologias e os distúrbios sexuais delimitados por sexólogos para explicar os desvios sociais da criminosa. Para o autor o comportamento monogâmico representava o topo da cadeia evolutiva feminina, sendo possível pontuá-lo em "mulheres morais", ou seja, "mulheres normais". Tratou, assim como Richard Von Krafft-Ebing ${ }^{67}$, considerado o pai da sexologia, da sexualidade normal e desviante nas mulheres, salientando que, quanto mais sexualizada uma mulher mais degenerada e desviante seria (GIBSON e RAFTER, 2004, p. 22).

Com o objetivo principal de reafirmar sua teoria sobre a criminalidade nata - segundo a qual os criminosos representam retorno a um estágio evolucionário ancestral, que o autor chama de "estado atávico", incompatível com as leis da civilização - Lombroso escreveu La Donna Delinquente, la Prostituta e la Donna Normale, agora buscando assinalar os traços degenerativos femininos (GIBSON E RAFTER, 2004, p. 7). Nas cinco edições de L'Uomo Delinquente, Lombroso havia exposto de maneira cada vez mais detalhada e aprimorada sua teoria sobre o criminoso nato, tendo tratado ainda que brevemente da criminalidade feminina, sendo que já na pri-

obra de Sheldon e Eleanor Glueck "Five hundred crimminal careers" de 1930 e outros (GIBSON E RAFTER, 2004, pp. 23 a 29)

66 A correlação entre sexualidade e criminalidade feminina está presente ainda hoje nos discursos sobre criminalidade feminina. A construção da imagem da mulher delinquente a partir de estereótipos sexuais é ressaltada por Natália Corazza Padovani em sua dissertação de mestrado denominada Perpétuos Espirais: Falas do Poder e do Prazer Sexual em Trinta Anos (1977 - 2009) na história da Penitenciária Feminina da Capital (2010).

$67 \quad$ Krafft-Ebing catalogou as sexualidades desviantes em sua obra Psychopatia sexualis publicada em 1886 (GIBONS E RAFTER, 2004, p. 21) 
meira edição de L'Uomo Delinquente considerava a prostituição o crime típico feminino (GIBSON E RAFTER, 2006, pp. 15 e 16).

Por que as mulheres delinquem menos que os homens foi uma questão que guiou Lombroso ao longo de sua carreira de pesquisador. Segundo Gibson e Rafter, em La Donna Delinquente, la Prostituta e la Donna Normale o autor se colocou uma tarefa complexa, pois, ao afirmar que as mulheres são menos atávicas que os homens, bem como que as mulheres são menos criminosas, pois inferiores a eles, criou um paradoxo: se menos atávicas por que inferiores, e não superiores? A partir desses pontos, lançou-se à pesquisa empírica, tendo como grupo de controle "mulheres normais" ou "mulheres morais" e se valeu não só de suas próprias análises, mas do auxílio de dados coletados por outros cientistas, como a médica russa Pauline Tarnowsky e Alexandre Parent-Duchatelet ${ }^{68}$ (GIBSON E RAFTER, 2004, p. 9).

Ao situar a obra em seu contexto histórico, Gibson e Rafter mostram como Lombroso foi influenciado por fatores externos na tipificação das mulheres delinquentes. Em especial, o crescimento populacional na recém unificada Itália, principalmente das classes baixas, aumentava a preocupação em relação às classes perigosas, nas quais estavam inseridas as prostitutas. Para as tradutoras:

a prostituta surge nesse contexto como iconografia das classes perigosas. Para observadores da classe média, o número crescente de mulheres desabrigadas e sem emprego nas ruas das cidades fazia parecer que todas fossem prostitutas. Culpadas por espalhar doenças venéreas, as prostitutas foram colocadas sob supervisão policial imediatamente após a unificação, tendo sido obrigadas a morarem em bordeis regulamentados pelo estado, nas chamadas 'casas fechadas' (GIBSON e RAFTER, 2004, p. 16).

68 De acordo com Gibson e Rafter, Pauline Tarnowsky publicou em 1889 estudo antropométrico em prostitutas russas, ao qual Lombroso teve acesso. Seu intercâmbio com a autora possibilitou o acesso a fotografias de prostitutas russas, já que a burocracia italiana dificultava a coleta de material desse tipo (LOMBROSO, 2004, p. 135). Já o estudo de Parent-Duchatelet, de 1836 denominado De La prostituition dans La ville de Paris também foi utilizado pelo autor, já nas primeiras edições de L'Uomo Delinquente (GIBSON E RAFTER, 2006, p. 16). 
Além disso, Gibson e Rafter chamam a atenção para o fato de que o livro foi escrito em uma época em que o movimento de mulheres por direitos - ao voto, à educação e ao trabalho - se organizava e se fortalecia na Europa. Possivelmente as mudanças estruturais na sociedade, que poderiam ser geradas por uma maior participação feminina na esfera pública, preocupavam Lombroso, que, apesar de politicamente liberal, temia profundas mudanças sociais. Segundo Gibson e Rafter, ao dedicar a primeira parte de sua obra La Donna Delinquente, la Prostituta e la Donna Normale a mostrar a inferioridade das mulheres o autor as coloca em seu devido lugar social, inclusive "sua ridicularização do intelecto feminino e sua insistência na maternidade como aspiração própria de toda mulher, cientificamente afirmava os estereótipos tradicionais e desafiava diretamente a visão da mulher emancipada" (GIBSON e RAFTER, 2004, p. 16). Lombroso utilizou suas conclusões científicas para naturalizar as diferenças dos papéis sociais de cada um dos sexos presentes na sociedade do período ${ }^{69}$ (GIBSON e RAFTER, 2004, p. 18).

Influenciado por Darwin e sua A Origem das Espécies, Lombroso tinha uma visão evolucionista do desenvolvimento humano. São inúmeros os momentos em que busca explicar o desaparecimento de determinada categoria ou de determinados traços de degenerescência com base na teoria da seleção natural. $\mathrm{O}$ autor assumia um ponto de vista monogenista, segundo o qual a origem humana era a mesma, apresentando-se o homem em diferentes estágios evolucionários, estando o branco europeu no topo da escala evolutiva e o negro africano no mais baixo degrau (GIBSON e RAFTER, 2004, p. 17; GIBSON e RAFTER, 2006, p. 17) .

Lombroso certamente incorporou à sua pesquisa preconceitos de seu tempo, tratando das representações sociais acerca das diferenças entre homens e mulheres, entre "raças" e grupos em conformidade com os padrões da época (GIBSON e RAFTER, 2006, p. 15). Assim, não é possível saber até que ponto suas teorias influenciaram criminólogos e estudiosos do tema, pois, por vezes, não se pode identi-

69 De acordo com as tradutoras, a teoria de Lombroso sobre a inferioridade intelectual e física feminina representou um retrocesso para o movimento de mulheres que se fortalecia na Itália e na Europa (2006, p. 17 e 2004, p. 16). 
ficar o que é oriundo do senso comum do período e o que vem dos ensinamentos de Lombroso e seus discípulos, a não ser quando explicitamente citados. Até que ponto a análise de Lombroso não é uma compilação de conceitos e preconceitos presentes na época com uma "roupagem científica", assim como as afirmações dos autores e penitenciaristas nacionais?

No entanto, a opção por explicitar as convergências entre os principais pontos da teoria lombrosiana sobre a criminalidade feminina e as análises de criminólogos brasileiros não perde sua força, pois, seja porque reproduz "cientificamente" (pré) conceitos do momento ou por inovações teóricas por ele propostas, nos traçados de Lombroso é possível visualizar um padrão de identificação da criminosa, presente nas falas dos penitenciaristas e autores nacionais, que ajudará a delimitar os estereótipos da delinquente à época da criação dos presídios femininos no país.

\section{ESTEREÓTIPOS - TRAÇANDO A “MULHER DELINQUENTE"}

Ao lado da mulher honesta e de boa familia condenada por um crime passional ou culposo, ou que aguarda julgamento, seja por um aborto provocado por motivo de honra, seja por um infanticídio determinado muita vez por uma crise psíquica de fundo puerperal, estão as prostituidas mais sórdidas vindas como homicidas da zona do baixo meretricio, as ladras reincidentes, as mulheres portadoras de tuberculose, siflis e moléstias venéreas ou de pele, hostis à higiene, quando não atacadas de satiriase, tipos acabados de ninfômanas, que submetem ou procuram submeter pela força as primeiras aos mais repugnantes atos de homossexualismo (...).

Lemos Britto, APB, 1942d, p.27

No trecho acima, que compõe o ante-projeto da Exposição de Motivos do Regimento da Penitenciária de Mulheres de Bangu, entregue por Lemos Britto ao Ministro da Justiça e Negócios Interiores, Alexandre Marcondes Campos, em 1942, 
é possível identificar uma "escala de criminosas". Há as mulheres honestas e de boa família condenadas, ou aguardando julgamento, por crimes passionais ou culposos; as mulheres honestas e de boa família já condenadas por aborto provocado por motivo de desonra, ou por infanticídio oriundo de crise puerperal; as prostituídas homicidas do baixo meretrício; as ladras reincidentes; as que possuem doenças contagiosas, em especial venéreas; e as portadoras de ninfomania. Não é possível separar tipos de mulher de tipos de crime, ou seja, o autor associa as categorias "mulher honesta" e/ou "de boa família", a determinados tipos de crime, enquanto as prostitutas do baixo meretrício são associadas a outros. A "promiscuidade" a qual se refere Lemos Britto diz respeito à mistura dessas mulheres de diferentes classes sociais, de diferentes índoles, e/ou de condenadas e processadas. Trata-se de uma promiscuidade que permite o contágio da pura pela impura, da recuperável pela irrecuperável.

As mulheres "honestas" e "de boa família" estão associadas a crimes: mais brandos, como os culposos; provocados por um estado próprio da natureza feminina, como o infanticídio; decorrentes da atitude de um terceiro que as desonrou, como o aborto; ou fruto de um estado de loucura, muitas vezes também vinculado ao feminino, como o crime passional ${ }^{70}$. Todos os crimes associados a elas são ocasionais, ou seja, é uma ocasião atípica que fez com que essa mulher se tornasse delinquente, como é o caso da desonra, do estado puerperal e/ou do crime culposo. A matéria do crime é também muito específica: o feto fruto da desonra, o objeto do ciúme, o bebê recém-nascido de uma mãe que não se controlou no pós-parto. Segundo o autor, essas mulheres não são criminosas a priori, mas por um acidente.

Por outro lado, há as "abomináveis" prostitutas oriundas do baixo meretrício, aquelas que não somente são prostitutas, mas vindas de um local sujo, vulgar, amoral e anti-higiênico. Essas mulheres estão associadas ao homicídio. Não há uma especificação se culposo ou passional, ou qualquer qualificação para o crime - são homicidas. Já as ladras reincidentes são aquelas que teriam uma índole criminosa. $\mathrm{O}$ autor

$70 \quad$ Sobre o crime passional, Lemos Britto ressaltava em seu livro Psychologia do Adultério, de 1933, que o Brasil era o país em que mais se "matava por amor no mundo", o que assemelhava o seu povo aos povos mais bárbaros. Havia muitos assassinatos de mulheres por seus maridos. 
não explicita o crime cometido por aquelas portadoras de doenças mas, ao mencioná-las, as coloca em oposição às mulheres honestas, que estariam no outro extremo da "classificação". Além da tuberculose e de doenças de pele, Lemos Britto ressalta ainda as doenças venéreas e a sífilis, moléstias típicas da atividade sexual promíscua e desregrada, colocando todas as portadoras de doenças no balaio das "avessas à higiene".

Finalmente, associa as mulheres da categoria "impura" - prostitutas, ladras e contagiadas - à possibilidade de sofrerem de distúrbios sexuais, como a satiríase e/ ou a ninfomania. Satiríase é uma patologia específica de homens, configurada pela excitação sexual exagerada masculina, considerada mórbida. Já a ninfomania é a versão feminina da satiríase. $\mathrm{O}$ autor vincula esses males masculinos e femininos àquelas que, em uma posição ativa, submetem as "mulheres honestas", passivas, a práticas homossexuais. Na visão do autor, a perversidade nessas mulheres é tamanha, que chega ao ponto de adquirirem características típicas de uma patologia sexual masculina, ou seja, não só "se tornam homens", como os mais perversos exemplares de homens. Assim, no trecho em questão, é possível notar que para o autor prostituta e boa mulher são categorias opostas, representadas, respectivamente, pelos adjetivos "sórdidas" e "honestas".

É ainda Lemos Britto que, em conferência denominada As Mulheres Criminosas e seu Tratamento Penitenciário, publicada em 1943 pela Imprensa Oficial, ao falar sobre a situação das detentas na Casa de Detenção na cidade do Rio de Janeiro, reitera a clivagem feita anteriormente entre os tipos de criminosas. Mais uma vez, é possível perceber que na escala traçada pelo autor, prostitutas, reincidentes e mulheres com doenças contagiosas se opõem às "delicadas" moças de família que cometeram seus crimes sob impulso ocasional. Em suas palavras:

(...) viviam e ainda vivem juntamente a moça delicada que sob a influência puerperal, ou por motivo de honra, praticou um infanticídio, ao lado da prostituta nauseabunda que matou para roubar e a homicida passional ombro a ombro com a ladra profissional e com as mulheres cobertas de enfermidades transmissíveis como os vícios de que são portadoras (LEMOS BRITTO, 1943, p. 8). 
O artigo 266 do Anteprojeto de Código Penitenciário ${ }^{71}$ de 1933, ao mesmo tempo em que proibia a existência de seções de mulheres no mesmo edifício das casas de detenção, possibilitava "a construção de pequenos pavilhões a elas destinados, com a natural separação entre as condenadas e as que aguardavam sentenças, e, quanto às condenadas, entre mulheres honestas e as de maus precedentes" (grifo meu) (APB, 1942d, p.29). Tal anteprojeto, redigido por membros do Conselho Penitenciário, como Cândido Mendes, Lemos Britto e Heitor Carrilho, refletia o posicionamento de que havia tipos distintos de mulheres delinquentes, e que era necessário separá-las.

Entre os documentos que tratam especificamente da criminalidade feminina, nenhum outro faz separação tão maniqueísta como a de Lemos Britto no texto do Anteprojeto do Regimento da Penitenciária de Bangu. Em geral, os estereótipos criminosos são destilados em análises "sociológicas" sobre a delinquência feminina, que indagam se a mulher é ou não mais criminosa que os homens e questionam os baixos índices de mulheres delinquentes no país. Nesses textos é possível, no entanto, verificar a vinculação entre pobreza, prostituição e criminalidade, também presente no texto de Lemos Britto.

Em artigo já mencionado, publicado no periódico Arquivos da Sociedade de Medicina Legal e Criminologia de São Paulo, Hilda Macedo frisa que as mulheres que cometem crimes “(...) são, em geral, vítimas da miséria; da miséria moral, da miséria econômica, da miséria eugênica, da miséria pedagógica" (MACEDO, 1953, p. 287). A seu ver, contribuem para a criminalidade fatores endógenos, que são internos e próprios de cada indivíduo, bem como exógenos, que são referentes às influências do meio no qual ele convive. No caso da criminalidade feminina, o fator exógeno de maior influência é o econômico. Em suas palavras, a mulher,

71 De acordo com Dotti, em 1933, Cândido Mendes de Almeida, José Gabriel de Lemos Brito e Heitor Carrilho redigiram e apresentaram ao Governo Federal um Anteprojeto de Código Penitenciário. Outros juristas e estudiosos da questão penitenciária, como Oscar Stevenson, Roberto Lyra e Benjamin Moraes Filho, apresentaram anteprojetos penitenciários respectivamente nos anos de 1957, 1963 e 1970. No entanto, nenhuma das quatro propostas chegou sequer à votação no Congresso (A reforma penal e penitenciária 25 anos depois, disponível em: www.dotti.adv.br/artigosjp 319.html, acesso em 30/05/2011). 
predisposta diante da falta de recursos econômicos, começa, quase sempre, enveredando pela prostituição, e da prostituição ao crime é um passo, já que esta, se não for um crime, é entretanto equivalente dele. $\mathrm{E}$ as nossas delinqüentes, via de regra, são mulheres de escassos ou nulos recursos econômicos. (MACEDO, p. 288, 1953).

A prostituição aparece novamente vinculada ao crime, como se fosse impossível distinguir uma do outro, já que ambos são considerados comportamentos oriundos de uma fraqueza moral. A autora relaciona falta de recursos econômicos à prostituição e esta à criminalidade, criando um estereótipo possível da criminosa feminina. Para ela, além da questão econômica, há outro fator exógeno que pesa bastante na balança da criminalidade feminina: o déficit pedagógico e moral. A ausência de família, ou o convívio em famílias desorganizadas, que não passam ensinamento ético e moral a seus descendentes, é catalisadora da criminalidade. Em sua análise, pode-se notar de forma clara a diferenciação entre "boa família”, "ausência de família" e "família desestruturada", e o peso que isso tem na formação de delinquentes. A autora pontua que:

das famílias honestamente constituídas é lícito esperar representações morais, trato eugênico, orientação pedagógica. Mas, e se a criança não tem família, ou se a tem, esta não lhe proporciona o mínimo indispensável para que não sobrevenham no futuro esses déficits? Fica ela, em geral, abandonada pela própria sorte, candidata, fatalmente, à delinqüência (MACEDO, p. 289, 1953).

Ora, é possível concluir, pela linha de raciocínio da autora, que mulheres vindas de uma família organizada, "honestamente constituída" e sadia, quando delinquem, o faz ou por razões endógenas ou por uma "ironia do destino". Já as que são oriundas de famílias que não lhes proporcionaram ensino ético e moral poderão, com facilidade, tornar-se delinquentes. Macedo, no entanto, trata das famílias de maneira indiscriminada, não associando diretamente classe social a famílias mais ou menos estruturadas. 
Na seção de pareceres dos Arquivos Penitenciários do $4^{\circ}$ trimestre de 1940, há o parecer de número 3.327, assinado por membros do Conselho Penitenciário do Distrito Federal, no qual todos eram favoráveis à diminuição da pena de H. C. C., condenado por ter matado sua amante, A. R. C., "mulher de vida fácil". A posição dos conselheiros, para além dos argumentos jurídicos, se dava porque o condenado, antes homem honesto, bem casado e trabalhador, havia sido ludibriado pela vítima, mulher por quem se apaixonou. De acordo com os pareceristas:

a situação desse homem não deve e não pode ser encarada apenas no período de arruinamento moral que precede ao crime - é preciso confrontá-la com o seu passado antes que a mulher em apreço lhe houvesse despertado a paixão sob cuja influência foi sendo aos poucos soterrado entre ações que mais do que a abjeção do caráter parecem concretizar, através da obsessão amorosa, a abolição do caráter consciente (APB, 1941a, p. 218)

A contraposição entre "a primeira parte de sua vida” e os tempos em que viveu ao lado da "mulher de ínfima condição moral" funciona para os pareceristas como uma balança, na qual o peso da moralidade pregressa supera o da imoralidade posterior: o homem honesto é contraposto à mulher imoral, a família organizada é contraposta à vida na casa de prostituição e o trabalhador decente ao homicida ocasional. A sordidez da amante parece justificar, ao longo do parecer, o crime cometido pelo condenado, bem como a certeza da diminuição da pena em cumprimento. Mesmo quando, como neste caso, a mulher é a vítima, a "escala” dos tipos femininos é colocada em uso, e o fato da vítima ser desqualificada justifica, em alguma medida, o ato de seu amante agressor.

Os diferentes níveis de criminosas expostos pelos penitenciaristas brasileiros já apareciam em 1893 na obra La Donna Delinquente, la Prostituta e la Donna 
Normale, de Cesare Lombroso, que apresenta uma escala que vai da criminosa nata - a pior de todas - à mulher honesta, que contém em si a potencialidade criminosa. Entre os dois pontos da escala estariam a prostituta nata, a prostituta ocasional e a criminosa ocasional. Dentre estas há ainda uma sub-escala, que considera as criminosas ocasionais que cometem crime com violência mais próximas da criminosa nata, ao passo que as demais são posicionadas mais perto das mulheres normais. Algumas mulheres normais poderiam, segundo Lombroso, cometer crimes ocasionais, como os crimes contra o patrimônio, dada a latente imoralidade feminina.

Em geral, as mulheres seriam, para o autor, inferiores aos homens tanto fisicamente quanto moral e intelectualmente. Existia, segundo Lombroso, duas categorias de mulheres: a) aquelas más, masculinizadas e primitivas; b) as civilizadas, femininas e seguidoras das leis. Apesar desta enorme diferença entre uma categoria e outra, havia traços comuns às mulheres, tais como a potencialidade intrínseca para o desvio e algumas características físicas e morais como: maior resistência à dor, semelhanças com as crianças, deficiência de senso moral, impulsos vingativos e ciúmes. Esses defeitos eram minimizados por sua capacidade de sentir pena, pela maternidade, pela frieza sexual, a fraqueza psicológica e a inteligência pouco desenvolvida (LOMBROSO, 2004, p. 183).

De acordo com Lombroso, a criminosa típica, ou criminosa nata, era mais rara entre as mulheres que os criminosos natos entre homens, pois o padrão de desvio de uma mulher normal ao seu ancestral atávico seria muito pequeno, devido à pouca mobilidade evolucionária feminina. Já os homens, por terem evoluído mais e atingido maior grau de civilização, quando se aproximavam do tipo primitivo, seriam desviantes absolutos, já que regrediriam muitos patamares na linha evolutiva. Segundo o autor:

a criminosa feminina é menos típica fisiologicamente que os homens criminosos, uma vez que ela é menos essencialmente criminosa, já que todas as formas de degeneração fazem com que a criminosa se desvie a um patamar mais próximo que os homens, pois sendo organicamente conservadora (há pouca variedade e evolução), ela mantém as caracterís- 
ticas do tipo "normal" mesmo quando desvia dele; e finalmente porque a beleza, sendo para ela de uma necessidade suprema, resiste aos assaltos da degenerescência (LOMBROSO, 2004, p. 149).

Isso explicaria porque Lombroso apresentou dificuldades em mapear características degenerativas em mulheres criminosas natas e prostitutas. Já nos homens, seria mais fácil identificar no corpo os estigmas do desvio, pois do degenerado ao civilizado havia muitas diferenças. O pequeno caminho percorrido pelas mulheres na escala evolutiva se daria, principalmente, pelo fato de que a natureza da mulher era pela manutenção, pela pouca mobilidade, pela pouca criatividade. As mulheres seriam conservadoras tanto socialmente quanto fisicamente, e a origem desse conservadorismo estaria na falta de mobilidade do óvulo feminino quando comparada à mobilidade do espermatozóide masculino. Ainda, o cuidado com a família, atividade tipicamente feminina, tornava a mulher reclusa ao lar, impedindo-a de evoluir como os homens, que estariam mais expostos socialmente (LOMBROSO, 2004, p. 147). Em relação à criminosa nata, Lombroso pontuava que era

(...) duplamente excepcional: como mulher e como criminosa. Isso porque criminosas são exceções dentre as pessoas civilizadas, e as mulheres criminosas são exceções dentre os criminosos, sendo a forma natural feminina de regressão a prostituição, não o crime. Por ser uma dupla exceção, a criminosa feminina nata é um verdadeiro monstro (LOMBROSO, 2004, p. 147).

É raridade mulheres com o tipo criminoso completo quando comparadas aos homens. Para Lombroso, o tipo criminoso feminino completo se aproximava moralmente do tipo criminoso masculino completo:

a fisionomia moral da mulher criminosa se aproxima daquela do homem criminoso. Há nas mulheres criminosas uma diminuição atávica dos caracteres sexuais secundários, o que é possível de se ver na antropologia do sujeito e nas suas características morais. A crimi- 
nosa é fraca em sentimentos maternais, inclinada à dissipação, astuta e audaciosa. Ela domina pessoas mais fracas, muitas das vezes por sugestão, algumas pela força. Seu amor por exercícios violentos, e mesmo as suas roupas se assemelham aos homens. Esses traços viris são, em geral, associados aos piores traços femininos: sua paixão pela vingança, a fofoca, a crueldade, sua astúcia, o amor pelos enfeites, a falta de honestidade, tudo pode ser combinado tornando um tipo extraordinariamente maléfico. Quando força muscular e poder intelectual vêm juntos em uma mesma pessoa, temos uma criminosa feminina do pior tipo possível (LOMBROSO, 2004, p. 183).

Uma das grandes provas de degeneração residiria, para o autor, no fato de as mulheres criminosas natas não terem afeição maternal. Essa falta de amor materno era compreensível, dadas as suas características masculinas, como o excesso de sexualidade. Em geral, nas mulheres morais a sexualidade estaria canalizada na maternidade, enquanto as criminosas não teriam sentimentos dessa ordem, e, portanto, seriam péssimas mães. A insanidade mental, em geral oriunda da epilepsia, também estava presente nessas mulheres (LOMBROSO, 2004, p. 185).

Para Lombroso, a verdadeira criminalidade feminina, a mais recorrente e marcante, era a prostituição. Nesse sentido, a prostituta nata seria a principal representante da criminalidade feminina, assim como o criminoso nato seria o principal representante da criminalidade masculina. Segundo o autor, a prostitu$\mathrm{ta}^{72}$ nata se assemelhava psicologicamente e anatomicamente ao criminoso nato, pois ambos “(...) apresentam a mesma falta de senso moral, coração embrutecido, apetite juvenil pelo mal, indiferença para com a opinião pública, (...) o mesmo gosto por gratificações imediatas, orgias e bebidas, o mesmo tipo de vaidade" (Lombroso, 2004, p. 221). Assim, a prostituição e a criminalidade seriam fenômenos paralelos. A prostituta tinha a índole criminosa e só não cometia crimes comumente pois ganhava seu sustento de forma mais fácil. Nas palavras do au-

72 De acordo com Gibson e Rafter, ao tratar da prostituta, Lombroso foi provavelmente influenciado pela obra de Richard Dugdale, autor estadunidense que em 1877 escreveu The Jukes obra em que equiparava as prostitutas aos criminosos natos (GIBSON E RAFTER, 2004, p. 11). 
tor, apesar de ser uma forma de criminalidade “(...) a prostituição é socialmente útil como uma saída para a sexualidade masculina, e previne crimes masculinos. Às vezes a criminalidade funciona de maneira útil. O comportamento criminoso e a prostituição são duas formas, uma masculina e uma feminina, de criminalidade" (LOMBROSO, 2004, p. 221). Ademais, de acordo com o criminólogo, a mulher primitiva era prostituta e não criminosa, sendo, portanto, a prostituição mais próxima do comportamento primitivo que a criminalidade. $\mathrm{O}$ ancestral feminino natural seria, dessa forma, antes a prostituta que a criminosa (LOMBROSO, 2004, p. 148).

A origem da prostituição seria a "insanidade moral", possível de ser verificada nas prostitutas pela ausência de sentimentos como amor pela família. Tal "insanidade moral", ou "degeneração moral", impediria a manifestação das virtudes de evolução apresentadas nas "mulheres morais", apagando os sentimentos mais civilizados, como o respeito à vida, à família e aos outros. A patologia também geraria a criminalidade, motivo pelo qual as prostitutas praticavam, por vezes, crimes como roubo e homicídio. De acordo com o autor, aquelas que nasciam prostitutas não tinham o freio social que teria a mulher honesta, não resistindo às intempéries da vida. A seu ver, "à falta de modéstia e à insanidade moral se soma a facilidade, indiferença e mesmo alegria que as prostitutas têm de participar da profissão mais mal falada do mundo, que as banem da sociedade" (LOMBROSO, 2004, p.216).

Havia, ainda, as prostitutas ocasionais, que não nasceram prostitutas, mas se tornavam por necessidade. Em geral, elas amavam seus filhos e se prostituíam para colaborar com seus entes próximos. Sua devoção maternal as estimulava a fazer qualquer coisa para ajudar a família. Quando não estavam trabalhando, elas provavelmente sentiam vergonha e remorso de sua condição. As principais circunstâncias que levavam essas mulheres à prostituição eram, de acordo com Lombroso, a) a perda da virgindade (oriunda de uma sedução seguida de abandono ou estupro); b) a violência social e a esperteza dos que as enganavam levando-as contra vontade para o mercado da prostituição; c) pobreza e maus exemplos. A prostituta ocasional apresentava fraqueza para o vício, pois a mulher completamente honesta preferiria 
a morte à prostituição, já a prostituta nata teria uma necessidade orgânica para o vício (LOMBROSO, 2004, p. 222 a 226).

Existe uma clara continuidade entre os estereótipos da delinquência feminina traçados por Lombroso e a produção nacional sobre o tema, por exemplo, a vinculação entre prostituição e delinquência, as caracterizações do crime e da criminosa ocasional, e o próprio escalonamento de categorias mais ou menos criminosas dentre as mulheres. Apesar de a maioria dos artigos citados não mencionar explicitamente a obra de Lombroso, e as abordagens feitas serem menos biologizantes que as do autor italiano, é possível destacar pontos comuns entre eles. Há uma associação direta entre criminalidade e prostituição para os estudiosos brasileiros, que, apesar de não tratarem a prostituta como uma "criminosa nata" nos moldes lombrosianos, a apontam como figura criminosa e perigosa. A prostituta é associada, sem ressalvas, pelos autores nacionais citados, à criminalidade, como se fosse intrínseca a relação entre crime e prostituição, como pode ser verificado nas reflexões de Macedo e de Lemos Britto, no anteprojeto de Código Penitenciário e no parecer dado pelos conselheiros, mencionados anteriormente.

As criminosas ocasionais, para Lombroso, compunham a maior parte do universo de crimes femininos. Desprovidas de traços degenerativos, elas não apresentavam, em sua maioria, problemas com sensibilidade e sentidos. São considerados crimes ocasionais: o roubo, o furto, em alguns casos a mendicância, o aborto e o infanticídio. As mulheres que cometiam esses crimes por pressão de outros teriam em si latentes ímpetos criminosos, mas deveras fracos para se manifestarem sozinhos. Haveria casos em que os sentimentos maternos seriam fracos e elas acabariam caindo no crime. $\mathrm{O}$ autor cita o depoimento de uma freira com quem conversou em um presídio, segundo a qual as criminosas ocasionais “(...) não são como homens. Elas não cometem crimes por uma paixão maléfica, mas para satisfazerem seus amantes. Elas roubam e se comprometem pelos homens, algumas vezes sem mesmo ter interesse no crime cometido" (LOMBROSO, 2004, p. 194).

Lombroso ainda tratava dos crimes de paixão, em geral cometidos por excesso de amor que levava as mulheres a delinquir, sendo tais criminosas semelhantes aos 
criminosos passionais. No entanto, para ele, elas premeditavam mais e organizavam melhor o crime que os homens. As criminosas passionais eram, em geral, mulheres morais que apresentavam afetos mais exaltados que o padrão, e não conseguiam conter os seus instintos criminosos. Os crimes passionais originados de um egoísmo extremo, segundo o autor, eram resultado de "uma lenta fermentação da maldade latente em mulheres normais" (LOMBROSO, 2004, pp. 201 a 208).

Classificava Lombroso, dentre esses crimes, os cometidos por pressão social, por exemplo, o infanticídio, que seria mais frequente quando a ilegitimidade de crianças era tratada com maior rigor, pois o medo da desonra conduziria as mulheres ao crime. $\mathrm{O}$ aborto, ainda para Lombroso, poderia ser cometido devido à pressão social. Assim, a seu ver, alguns crimes de paixão eram causados pela opinião pública e pelo preconceito ${ }^{73}$. Nesses casos, o autor era a favor de uma punição menos rígida para as mulheres, uma vez que seus crimes não vinham de características natas, mas sim de estigma social (LOMBROSO, 2004, p. 204).

Igualmente, as delineações das criminosas ocasionais feitas por Lombroso se repetem nas configurações desse tipo de criminosa realizadas por autores brasileiros. A criminosa ocasional seria menos perigosa que a criminosa habitual, e cometeria seus crimes por razões específicas, como para a manutenção da honra, e por questões econômicas e sociais. Essa perspectiva também estava presente entre os penitenciaristas brasileiros, para quem, por exemplo, o aborto e o infanticídio poderiam ser uma resposta ocasional de uma mulher a uma agressão social, como o abandono e a desonra.

Apesar de Lombroso não tratar especificamente de soluções carcerárias em sua obra, é possível pontuar, em sua escala, as mulheres passíveis de recuperação, pois acometidas de ímpetos criminosos súbitos e anuláveis por elementos como o "sentimento materno"; e aquelas que nascem degeneradas e, portanto, estariam fadadas à criminalidade e à não-recuperação. A despeito dos mais de quarenta anos que sepa-

73 De acordo com Gibson e Rafter, Lombroso propunha alternativas para o aprisionamento feminino nos casos de aborto e infanticídio, pois eram crimes cometidos devido à forte pressão social (2004, p. 20). 
ram os penitenciaristas e outros autores nacionais da análise lombrosiana, sua tipologia da delinquência feminina é repetida com naturalidade, o que denota a pertinência, ainda nas décadas de 1940 e 1950, das observações feitas na primeira grande obra escrita sobre a delinquência feminina, no final do século XIX.

Estava presente nas análises dos penitenciaristas brasileiros a ideia de que quanto maior a proximidade de componentes civilizatórios - como a educação e a moral - e quanto mais distante de uma natureza descontrolada, menor seria o potencial delitivo de uma mulher. Esses penitenciaristas associavam as mulheres mais delinquentes a um descontrole que remetia à sexualidade exacerbada, aos vícios, à falta de moral e à ausência de senso de honestidade. Essa associação estava presente na obra de Lombroso, que relacionava a mulher a uma natureza primitiva enquanto os homens estariam em um estágio mais avançado de civilização. Interessante notar que tanto para Lombroso quanto, mais tarde, para os brasileiros, alguns crimes femininos são associados à sexualidade patológica, a loucuras próprias da "natureza feminina", ao estado puerperal e, portanto, a certos elementos "naturais"; enquanto outros são gerados pela civilização, como os crimes ocasionais de furto e o aborto. A solução para saná-los é encontrada tanto na educação e na moral quanto também em aspéctos da "natureza feminina", especialmente em seu potencial materno. Enfim, na "natureza feminina", para Lombroso, residia tanto o perigo quanto a salvação das mulheres. Seria no plano das construções sociais de uma "natureza feminina boa" - o potencial reprodutivo a ser trabalhado na maternidade - que aquilo que é intrínseco à mulher deveria ser retomado, ao passo que a "natureza feminina negativa" - a sexualidade não reprodutiva e os ímpetos associados à loucura - deveria ser afastada, com o apoio dos métodos civilizatórios de educação e moral.

Por fim, vale ressaltar que no caso específico do crime de adultério, há uma alusão direta feita por Lemos Britto em seu Psychologia do Adulterio a La Donna Delinquente, la Prostituta e la Donna Normale, na qual o autor discorda, em parte, de alguns pontos levantados por Lombroso, mas não deixa de citá-lo como referência no tema. Segundo Lombroso, toda mulher era naturalmente e organicamente monogâmica e frígida - por essa razão, as mulheres eram socialmente punidas de ma- 
neira mais severa que os homens em casos de adultério, uma vez que seria contra a sua natureza ser adúltera. Já o adultério masculino não era tratado sequer como um delito, o que Lombroso considerava uma injustiça, dada a maneira rigorosa como as adúlteras eram tratadas. Tal ausência de sentimento feminino apresentava, a seu ver, um paradoxo quando em pauta a necessidade feminina de “amor", já que este é o que há de mais importante na vida de uma mulher. Importante notar que, segundo Lombroso, "a necessidade de amor não é oriunda do erotismo, mas sim do instinto maternal presente nas mulheres e na necessidade de ser protegida, sem o que a existência feminina estaria incompleta”. O autor exemplificava a necessidade feminina de ser mãe com uma frase bíblica, na qual Raquel dizia ao seu marido Jacob "faze-me ter filhos (...) ou eu morro" ${ }^{74}$. Para ele, tal clamor continha em si uma verdade fisiológica - todas as mulheres necessitam da maternidade, sendo esta a mola propulsora feminina. A seguir, reproduziu como máxima de verdade uma frase do ginecologista italiano Giordano, segundo o qual: "os homens amam as mulheres por suas vulvas, enquanto as mulheres amam os homens como esposos e pais" (LOMBROSO, 2004, p. 60).

Ao refletir sobre o adultério feminino em seu Psychologia do Adulterio, Lemos Britto cita Lombroso apontando que "o grande revolucionador da criminologia sustentou a these de que a sensibilidade sexual é menor na mulher do que no homem” (Lemos Britto, 1933, p. 169), e ressalta, inclusive, o exemplo bíblico dado pelo autor. Lemos Britto, porém, discorda de Lombroso: a seu ver, o fato de as mulheres serem menos adúlteras que os homens não é proporcional à sua falta de sensibilidade, mas diz respeito a hábitos socialmente atribuídos às mulheres. Ao seu ver,

a mulher não é a fria e insensível organização a que se referem Sergi e Lombroso, nem a exaltada amorosa que cede facilmente e que, por força de sua própria sensibilidade, de-

74 Gênesis 30,1 - Diálogo de Raquel com Jacob em que ela, ao não conseguir engravidar - enquanto sua irmã Lia, também casada com Jacob, já havia tido quatro filhos - suplica ao marido: "faze-me ter filhos também, ou eu morro"Jacob prontamente responde: “acaso estou eu no lugar de Deus que te recusou a maternidade?”. Só depois de bastante tempo deu à luz seu primeiro filho biológico. São os doze filhos de Jacob, com Raquel e Lia, que darão origem às 12 tribos de Israel. 
pressa esquece os freios moraes, e cae. O que se observa é isto: - a mulher é tão amorosa quanto o homem, e soffre, como elle, a acção de seus instinctos, mas o habito ancestral fixado da castidade e do pudor deram-lhe molas especiaes de dominio sobre si mesma (LEMOS BRITTO, 1933, p. 171).

De acordo com Lemos Britto, os sentidos pouco pesam na prática do adultério, sendo as motivações das mulheres adúlteras oriundas antes de fatores educacionais e econômicos que sensoriais. A justificativa econômica do adultério jazia no fato de, no casamento, muitos homens não conseguirem arcar com as despesas do lar e da família, abandonando-os. As mulheres precisavam, então, de fortes motivações morais para não caírem na tentação de se relacionar com outro homem que lhes garantiria conforto e cuidado. É, na visão do autor, difícil que uma mulher seja adúltera quando o marido for presente e cumprir todos os requisitos do matrimônio. Já em relação às razões educacionais para o adultério, Lemos Britto afirma que quanto mais uma mulher aprendesse uma "moral doméstica sem falhas" e fosse educada em um ambiente virtuoso, menores seriam as chances de se tornar adúltera (LEMOS BRITTO, 1933, pp. 171 a 179). Já em famílias que apresentassem traços degenerativos, o atavismo poderia ser responsável pelo adultério em mulheres bem educadas e moralmente sãs, uma vez que as leis naturais poderiam superar as leis morais. Nesse sentido, culpar o excesso ou a ausência de sentidos pelo adultério, como o fazia Lombroso, faria sentido, para o jurista, apenas em casos específicos “(...) de mulheres predestinadas, por taras orgânicas, a se fazerem adúlteras, como fóra do casamento, seriam fatalmente prostitutas (...)” (LEMOS BRITTO, 1933, p. 172). O autor conclui que a única forma de evitar os adultérios seria pelo investimento na família, que deveria se organizar "sobre a base de um verdadeiro amor, limpa de prejuisos sociaes e economicos e que nada se obterá de valioso se não proceder uma educação severa e cautelosa dos futuros cônjuges, especialmente da mulher" (LEMOS BRITTO, 1933, pp. 199).

Embora Lemos Britto cite Lombroso para apresentar outro ponto de vista, a menção demonstra que o criminólogo italiano faz parte do universo de referência 
do autor e, especificamente, que teve acesso a La Donna Delinquente, la Prostituta e la Donna Normale. É possível fazer uma aproximação entre a abordagem de Lemos Britto em relação ao adultério e a perspectiva biologizante da antropologia criminal, no sentido de que, ao ressaltar que as mulheres sujeitas a herdarem caracteres degenerados eram mais suscetíveis a serem adúlteras, Lemos Britto atribuía à conduta delitiva características inatas. No entanto, a abordagem do jurista é principalmente sociológica, pois aponta soluções para combater o adultério que apelam para a educação e para a reestruturação social, e não para um "tratamento" que cure degeneradas.

\section{MAIS OU MENOS CRIMINOSA?}

Como se constata à primeira vista, a criminalidade feminina em São Paulo é representada por totais quase insignificantes, correspondendo a $11 \%$ da criminalidade masculina. Aliás, como frisamos em várias oportunidades, o elemento feminino, quer nas estatísticas brasileiras, quer nas alienigenas, pouco aparece nos delitos, em virtude de sua constituiçãa frágil, da força e agilidade limitadas. Com efeito, as particularidades fisicas e fisiológicas da mulher tornam-na incompativel com determinadas modalidades de crime, sem que, todavia, ela deixe de figurar nas estatisticas de moral negativa. Surgem em número apreciável nas pequenas ocorrências, sobressaindo, principalmente nos chamados pequenos furtos, que, em dezenas e dezenas de casos näo chegam sequer a ser objeto de investigação policial, pela ausência de provas e até mesmo pela não apreciação da queixa, o que se dá frequentemente em relação aos furtos praticados por domésticas (criadas de servir). Em geral o prejudicado prefere sofrer a perda do dinheiro e de objetos de valor, a ficar sem empregada.

Estatística policial criminal do Estado de São Paulo, 1944, p.197

O trecho acima, retirado do anuário estatístico policial do Estado de São Paulo, do ano de 1943, reforça estereótipos da época em relação à criminalidade feminina. $\mathrm{O}$ relator atribui a pequena porcentagem de mulheres detidas a elementos 
físicos, como a reduzida força física feminina, e sociais, como a opção, feita por algumas pessoas lesadas, de não denunciar mulheres. Além da seleção dos estereótipos criminosos femininos, havia, no período analisado, uma tentativa de explicar os baixos índices de criminalidade feminina: era recorrente o questionamento, feito por penitenciaristas e demais pensadores, se a mulher era menos criminosa que os homens, uma vez considerados os reduzidos percentuais de mulheres cumprindo pena ou aguardando julgamento no Brasil e em outros países. Na avaliação de alguns autores é possível notar lugares comuns sobre as mulheres criminosas, bem como apontar razões atribuídas à criminalidade feminina, a fim de traçar o perfil da criminosa.

Lemos Britto, ao falar sobre a importância de separação entre mulheres e homens, independentemente do baixo número de mulheres presas, cita obra de Roberto Lyra, Direito Penal, na qual o autor sintetiza opinião prevalente na doutrina jurídica sobre o tema da seguinte maneira: a) a mulher está menos sujeita aos choques e às necessidades da vida; b) a mulher não usa armas, nem bebidas alcoólicas, nem frequenta lugares viciosos; c) as emoções da mulher são de outra natureza e a encontram preparada pela educação doméstica e religiosa para a resignação e para a abstinência; d) porque os seus crimes ocorrem no ambiente doméstico escapando ao controle da autoridade pública; e) porque o cavalheirismo dos homens não as pune nem as delata, e, quando excepcionalmente ocasionam processos, a regra é a absolvição ou comutação ${ }^{75}$ (APB, 142b, pp. 309 e 310).

Os cinco pontos levantados por Lyra são bastante elucidativos da visão predominante sobre a criminalidade feminina à época. $\mathrm{O}$ argumento de que a mulher está menos sujeita aos choques e às necessidades da vida aparece em outras análises, que igualmente associam os baixos índices de criminalidade feminina à ausência da mulher no mundo público: enquanto restrita ao universo privado, protegida no lar tanto pelos pais quanto pelo marido, não precisa enfrentar o "mundo lá fora", logo

75 Tais pontos são igualmente ressaltados no anuário estatístico criminal do Estado de São Paulo do ano de 1938, no qual o relator se questiona como é possível que um ser mais irritável e emocionalmente instável como a mulher cometa menos crimes que os homens. Além destes, o relator apresenta outros pontos de ordem biológica, que atribuem a criminalidade feminina a períodos de alterações hormonais, como o de menstruação (pp. 156 e 157). 
são menores as possibilidades de delinquir. Nesse mesmo sentido argumenta Hilda Macedo, para quem quando as mulheres passam a frequentar o universo público, espaço social criado e frequentado pelos homens, estas se deparam com muitos obstáculos, e muitas vezes, despreparadas para enfrentá-los, delinquem na tentativa de superá-los. Isso significa, segundo a autora, que a mulher não é biologicamente inferior ao homem, mas sim socialmente (1953, p. 287).

Nesse mesmo sentido, Victório Caneppa se manifesta em artigo d' A Estrela questionando se a mulher é ou não mais criminosa que o homem. Caneppa, assim como os demais autores citados, vincula os baixos índices da criminalidade feminina à pequena presença desta no âmbito público, estando, portanto, o homem mais suscetível a delinquir. Para o autor: “(...) ainda estamos muito atrazados, porque o índice de criminalidade da mulher traduz o progresso de uma coletividade. Parece ironia que esta evolução possa ser definida por aquela involução, mas a realidade tem desses absurdos". Concorda com Macedo ao afirmar, ainda que "vivendo à margem das atividades mais agudas, seus menores contactos com a vida isentam-na dos perigos sociais que conduzem mais frequentemente os homens ao crime. Estes defrontam-se com os problemas, ao passo que as mulheres dependem do resultado deste embate" (AE set/out de 1951, pp. 23 e 24).

É interessante como a associação entre aumento da criminalidade feminina e acesso à esfera pública está igualmente presente na obra de Lombroso, que associava diretamente a maior participação das mulheres na esfera pública ao aumento dos índices de criminalidade entre mulheres. Ele ressaltava que, na medida em que oportunidades para delinquir surgiam, mais subiam os índices de delinquência feminina. A interação entre as mulheres, que eram naturalmente fúteis e levianas, e a cidade em crescimento chamava a atenção do autor, que associava a chegada das lojas de departamentos às grandes cidades à tentação das mulheres que, para suprirem suas futilidades, cometiam roubos e furtos. Lembra também as empregadas domésticas que roubavam com frequência as casas onde trabalhavam, associando o trabalho fora de casa à possibilidade de delinquir. De acordo com o autor, a ganância feminina é despertada em algumas ocasióes envolvendo patrimônio e dinheiro, o que, 
na cidade em crescimento e nos novos papéis assumidos pela mulher, acontecia cada vez mais (LOMBROSO, 2004, p.199).

Ainda em relação à esfera pública, Lombroso fazia uma comparação entre a mulher e o homem no mundo de então: apesar das críticas que um capitalista recebia, dizendo que os homens estavam cada vez menos leais e honráveis, não havia como comparar a vaidade e a fofoca femininas com o mundo dos negócios, pois:

a desonestidade de um banqueiro é necessária na luta comercial, uma vez que ele é desleal com o parceiro na competição do trabalho, e isso faz parte da regra do jogo. Já a fúria vingativa feminina contra uma rival mais bem vestida é imoral, na medida em que denota seu egoísmo e é focada em alguém que está meramente exercitando um direito (LOMBROSO, 2004, p. 80).

O segundo ponto levantado por Lyra, o fato de a mulher não usar armas, nem bebidas alcoólicas, nem frequentar lugares viciosos remete-se ao primeiro ponto, ou seja, vincula a mulher ao lar, e, portanto, a um lugar mais protegido, ao mesmo tempo em que "explica" a criminalidade de prostitutas e mulheres "desviadas". Quanto mais vicioso o lugar que frequentam, mais viciosas se tornam. A oposição entre o lar e a rua aparece, mais uma vez, bem como a assimilação de homens com o público e mulheres com o privado.

Vale ressaltar a menção feita por Lombroso em La Donna Delinquente, la Prostituta e la Donna Normale de que as mulheres estariam distanciadas do canibalismo, do álcool e das armas por serem fracas. Fracas em caráter, em sensibilidade e em personalidade, as mulheres teriam menos sensibilidade, maior impulsividade e menor grau de controle sobre sentimentos maléficos, o que justificava não terem acesso a práticas e elementos perigosos. (LOMBROSO, 2004, p. 73).

$\mathrm{O}$ argumento biologizante de que as emoções da mulher são de outra natureza, justificam o argumento social de que tal natureza facilita a educação doméstica e religiosa recebida, que as prepara para a resignação e para a abstinência. Essa associação entre naturezas emocionais distintas e tratamento social adequado, está calca- 
da na divisão social de papéis entre homens e mulheres explicada por diferenças biológicas. A mulher, que tem o potencial de ser mãe, carrega em si o dom do cuidado e da doação para o próximo. Abrir mão de seus desejos, se os tiver, e se entregar aos cuidados do lar, dos filhos, dos mais velhos, do marido, é ação facilitada pela natureza feminina, que lida com resignação com o seu destino. Isso justificaria o menor número de crimes de autoria de mulheres do que de homens.

Nesse sentido, os argumentos de Hilda Macedo que relacionam delinquência e déficit de instruções éticas e morais dialogam com o terceiro ponto levantado por Lyra. Para ela, era urgente que fosse feita “(...) uma campanha veemente e sem tréguas pela volta do ensino de instrução moral e cívica nas escolas, e pela criação de cursos pré-nupciais - não apenas nos grandes centros, mas em todos os rincões da nossa terra" (1953, p. 288). Esta seria uma forma de conter a criminalidade tanto das mulheres, quanto de seus filhos, e permitir que a sociedade não caísse num abismo de imoralidade e falta de valores.

A subnotificação dos crimes femininos, quarto ponto explicitado por Lyra, se dava pelo fato destes ocorrerem no ambiente doméstico escapando ao controle da autoridade pública. A relação entre a esfera pública e privada, mais uma vez aparece de modo a frisar que o lar, ao mesmo tempo em que protege a mulher, pois a deixa resguardada dos desafios do mundo público, a resguarda do olhar do sistema de justiça, que raramente consegue adentrar no mundo privado. Quanto mais expostas ao mundo público, tanto mais passíveis de serem desmascarados os possíveis ilícitos por elas cometidos. Hilda Macedo também levanta este ponto em sua análise ressaltando que, possivelmente, se fossem contabilizados todos os abortamentos dolosos cometidos no âmbito privado, o número de homens e mulheres delinquentes se equipararia (153, p. 288). Lemos Britto, nesse sentido, realça, porém, que há também uma possível subnotificação de crimes ocorridos por homens no âmbito privado, uma vez que a mesma lógica funcionaria para eles. Em suas palavras:

quantos, porém, serão os atos idênticos praticados intra-muros pelos homens e que igualmente escapam à ação policial e da justiça? Bastaria lembrar os ébrios, os epiléticos, os 
impulsivos, que praticam diariamente nos lares atos que a lei capitula como crimes, injúrias graves e sevícias, contra esposas e filhos, que sofrem em silêncio, apenas com o testemunho dos vizinhos mais próximos, e, por amizade misturada com resignação, não os denunciam". (APB, 1942b, p.310)

Por fim, Lyra pontua um jargão comum nas análises sobre a criminalidade feminina à época, qual seja, o cavalheirismo dos homens que fazia com que estes não punissem ou delatassem as mulheres. Esse cavalheirismo se manifesta tanto no âmbito público como no privado, uma vez que o homem não denuncia as mulheres de sua casa - mãe, filhas, esposas, irmãs -, ao mesmo tempo em que operadores do direito não as julgam com o mesmo rigor com que julgam os homens. O cavalheirismo no âmbito privado se remete às relações particulares, ao universo doméstico e aos poderes nele estabelecidos, o que acaba influenciando a subnotificação dos delitos cometidos por mulheres.

Já o cavalheirismo público seria aquele refletido em uma justiça leniente em relação às mulheres, dada a sua "fragilidade" e "candura", ou mesmo a uma inabilidade masculina em lidar com o outro sexo. De acordo com o argumento exposto por Lyra, uma vez notificados os crimes femininos, ou seja, uma vez rompida a barreira entre a casa e a rua, a mulher é exposta ao sistema de justiça. $\mathrm{O}$ "segundo tipo de cavalheirismo" entraria em ação a partir dessa exposição ao sistema de justiça, pois, quando excepcionalmente as condutas femininas delitivas ocasionam processos, a regra é a absolvição ou comutação. Tal “cavalheirismo” é claramente definido por Victório Caneppa, em análise feita em $A$ Estrela. Para Caneppa a mulher

(...) não é mais criminosa do que o homem porque o próprio homem a corteja, mantém para consigo um tratamento diverso daquele que usa no trato com seu semelhante em sexo; releva muitas faltas de sua parte e não revida suas ofensas e agressões. Há um ditado que ainda hoje regula a benevolência do homem com a mulher: "numa mulher não se bate nem com uma flor”...Há da parte dos homens um cuidado todo especial, e muito justo, pela mulher, pois ela é nossa esposa, nossa mãe. Em todo setor da vida a mulher 
desfruta do homem uma atenção muito compreensível. Um patrão nunca trata uma empregada da mesma maneira com que trata um empregado; um magistrado não condena a mulher com rigor idêntico ao que aplica ao homem, mesmo que seus crimes sejam iguais; o homem nunca revida os insultos da mulher com a mesma violência com que revida os de outro homem. Enfim, a mulher é a criatura delicada de quem o homem sempre espera alguma coisa e por quem alimenta uma admiração que o impede de julgá-la com a mesma severidade com que julga um varão (AE, set/out de 1951, pp. 23 e 24).

Para além dos cinco pontos levantados por Lyra, há ainda alguns argumentos que merecem explicitação, pois ajudam igualmente a traçar os estereótipos da criminosa. Dentre eles está a co-autoria feminina ou o estímulo ao crime por parte das mulheres. A mulher ardilosa seria a mentora de crimes executados por homens. Seria incentivadora direta de delitos, influenciadas por ciúmes, pirraça, futilidades. Segundo Victório Caneppa, “(...) a mulher, embora domesticamente virtuosa, não possui a consciência social do homem; extremamente vaidosa, é capaz de, por mero capricho, estimular o homem ao crime. Não pretendemos com isso afirmar que ela é mais responsável; queremos afirmar somente que não é menos responsável" ( $\mathrm{AE}$, set/out de 1951, pp. 23 e 24).

Essa visão da mulher chantagista e manipuladora aparece em Lombroso, para quem as mulheres seriam dissimuladas, sendo capazes de mentir e trapacear os homens por meio de suas ameaças. O autor apontava o poder que as mulheres possuíam de chorar e conseguir o que queriam, utilizando-se de provérbios italianos para mostrar como o choro se tratava de hábito feminino recorrente: "as mulheres guardam as lágrimas nos seus bolsos", "as mulheres choram quando elas podem e choram quando elas querem", “as mulheres têm dois tipos de lágrimas: um para a tristeza e outro para a dissimulação" e "as mulheres choram assim como os cachorros urinam" (LOMBROSO, 2004, pp. 63 e 64).

A mulher infantilizada é outra representação entre os estereótipos femininos que surge na análise de penitenciaristas. Lemos Britto, em artigo dos Arquivos Penitenciários, no qual explicita os motivos da necessidade de separar homens e mu- 
lheres nos estabelecimentos prisionais, cita a penitenciarista espanhola Concepción Arenal, em sua obra Estudios Penitenciarios, para quem não deveria haver um regime diferenciado para homens e mulheres, apenas menor severidade na disciplina em casos excepcionais, pois as mulheres se assemelhavam mais às crianças que os homens. Segundo Arenal, a distância entre o homem adulto e a criança era maior que entre a criança e as mulheres adultas, o que justificava, por vezes, tratamento penitenciário diferenciado para mulheres (APB, 1942b, pp. 309 e 310). A infantilização da mulher, aqui citada para justificar algumas diferenças nos tratamentos prisionais entre os sexos, também aparece na descrição das mulheres presas, como será demonstrado no próximo capítulo.

A comparação entre mulheres e crianças era recorrente na obra de Lombroso, para quem o que diferenciava umas das outras era o instinto materno e a compaixão das primeiras. Graças a esses sentimentos elas não tinham inclinações recorrentes às maldades, como tinham as crianças. A mulher seria má apenas quando impelida por circunstâncias externas ou quando tivesse um caráter perverso. Já em relação à mentira, o autor frisava que "as mulheres são crianças grandes e as crianças são mentirosas por excelência. É mais fácil para as mulheres mentir, e elas têm mais razões para fazê-lo do que nós" (LOMBROSO, 2004, p. 77 e 80).

A associação, presente tanto na literatura científica quanto no senso comum, entre as peculiaridades biológicas da mulher, como a menstruação e a gravidez, e alterações comportamentais, se fez presente nos documentos pesquisados. Lemos Britto, em sua obra sobre a questão sexual nas prisões, cita inúmeros autores com o objetivo de mostrar como a menstruação é um período patológico feminino, que deve ser considerado, inclusive, na prescrição de pena para crimes cometidos por mulheres durante a menstruação. O corpo feminino e suas alterações hormonais era objeto de análise científica e, em especial os criminólogos as vinculavam à maior propensão ao cometimento de ilícitos penais. De acordo com Lemos Britto:

nos períodos característicos de sua sexualidade, a mulher sofre não somente alterações orgânicas como padece de profundas modificações na sua afectividade e emotividade. É por esse 
motivo que já se considera, nos domínios da criminalidade, mui attenuada a responsabilidade da mulher nos períodos catameniaes [mesntruais] (LEMOS BRITTO, 1934, p.194).

O posicionamento de Lemos Britto seguia aquele de Lombroso, para quem a menstruação influenciava a prática de condutas femininas criminosas e violentas. De acordo com o criminólogo italiano, o roubo, as rebelióes e o roubo de perfumes e bibelots por histéricas eram crimes e condutas que o estado menstrual poderia facilitar. Em tempos de menstruação, gravidez e menopausa as mulheres ficariam em pior estado e cometeriam os piores crimes, segundo Lombroso, para quem o ciclo menstrual feminino era visto como parte de um fenômeno maior chamado sexualidade. Afirmava que mulheres com lascívia exacerbada tinham, geralmente, menstruação prolongada e exagerada, ou que o apetite sexual feminino aumentava ao longo da menstruação. Toda manifestação exacerbada do corpo feminino - menstruação em excesso ou escassa, desejo sexual aumentado (ou mesmo presente), a gravidez em si - era razão para uma alteração psíquica perigosa (LOMBROSO, 2004, pp. 159 a 164 e pp. 227 a 230$).$

A mulher, segundo Lemos Britto, era um ser de pouco desejo sexual, afirmação também presente na obra de Lombroso, para quem o desejo sexual feminino era percebido como uma possível patologia. Nesse sentido, Lemos Britto ressalta que "a erotização feminina faz-se mais por força da imitação e dos reflexos produzidos pela vida social, seducção do homem, leituras amorosas, embriaguez alcoólica, do que por influência espontânea do próprio instincto". Havia, a seu ver, poucas mulheres erotizadas, sendo estas exceções. De qualquer forma, a maternidade era vista como um componente capaz de anular o erotismo feminino e canalizá-lo de uma maneira eficiente, pois, em suas palavras, “(...) uma vez atingido o objectivo para que a natureza destinou a mulher, esta mesma erotização se transforma no complexo de sentimentos que caracterisam a maternidade" (LEMOS BRITTO, 1934, pp. 195 e 196). Era necessário canalizar a sexualidade feminina de modo a utilizá-la de maneira positiva, o que era possível por meio da maternidade. Aquelas que não eram mães deveriam ser estimuladas a constituir famílias ao sairem das prisões. Já as que eram mães, de- 
veriam desenvolver, no cárcere, compaixão e sentimentos capazes de estimular que o amor materno aflorasse, como forma de anulação da criminalidade.

Vale ressaltar a consonância desse discurso com a postura lombrosiana em relação à potencialidade da maternidade como fator de contenção da criminalidade, o que se dava por meio do despertar do sentimento de compaixão. Para o criminólogo italiano, quanto mais evoluído um povo, mais compaixão deveria haver entre seus membros. O cristianismo teve, a seu ver, o mérito não de criar a compaixão, mas de liberá-la e estimulá-la dentre seus seguidores. Em suas palavras:

com o cristianismo teve início o heróico período da piedade feminina. O cristianismo certamente não criou a compaixão feminina, como alguns alegam, uma vez que a compaixão teve uma formação lenta e evolucionária. Mas o cristianismo liberou a compaixão, trouxe-a à vida, colocou-a em movimento" (LOMBROSO, 2004, p. 67).

O amor materno seria o grande responsável por gerar compaixão nas mulheres. Lombroso ressaltava que "as crianças, os velhos, os doentes, os prisioneiros, os condenados, os animais incapazes de se defender são todas criaturas fracas que imploram por compaixão. Desde as origens da humanidade, a mulher tem cumprido um papel de defesa dos fracos: o da maternidade". A compaixão nas mulheres relacionava-se à abnegação e ao sacrifício, sentimentos oriundos tanto na fraqueza feminina quanto na maternidade, pois a mulher se abandonava e se doava tanto na caridade quanto no amor (LOMBROSO, 2004, p. 70). A sua fraqueza física e mental fazia dela cruel e compassiva ao mesmo tempo. Por ser fraca, a crueldade seria um sentimento que faria com que elas se sentissem superiores. As mulheres seriam menos sensíveis, mais impulsivas e maléficas. Por outro lado, a fraqueza fazia a mulher ser mais compassiva, uma vez que a forçava a usar a gentileza como forma de ganhar a afeição dos mais fortes (LOMBROSO, 2004, pp. 66 a 72).

Este potencial compassivo das mulheres, ressaltado por Lombroso, era uma das principais apostas dos idealizadores das penitenciárias femininas como forma de recuperação das delinquentes. Por mais perversa que fossem, existia uma espe- 
rança em sua recuperação por meio da ativação dos caracteres próprios do "sexo frágil”. A natureza feminina comportava sentimentos que permitiam às mulheres o exercício de tarefas do âmbito do cuidado, estando no estímulo ao zelo de si e do outro uma possível cura para a criminalidade. A crença na potencialidade ressocializadora das mulheres passava por esses atributos naturais, que, quando estimulados, possivelmente se sobressairiam. A alegada função do cristianismo de estimular o sentimento de compaixão feminina, ressaltada por Lombroso, foi considerada pelos idealizadores dos estabelecimentos prisionais femininos, uma vez que elas foram entregues à administração das religiosas da Congregação de Nossa Senhora da Caridade do Bom Pastor d'Angers.

De que maneira recuperar as mulheres desviantes para um "dever ser" feminino socialmente esperado? Como lidar com as diferentes categorias de delinquentes femininas, impedindo a contaminação de umas pelas outras e promovendo a recuperação de seus caracteres? Como deveriam ser os cárceres femininos que abrigariam os diferentes tipos de criminosas existentes? De que maneira aliar o encarceramento e a maternidade? A quem entregar a administração desses espaços, considerando que não era recomendada a presença de homens nos cárceres para mulheres? Como estimular a manifestação de características positivas tipicamente femininas sem, contudo, despertar a futilidade atribuída às mulheres? Como anular a sexualidade exacerbada e canalizá-la de uma maneira positiva? De que forma organizar o espaço prisional para receber mulheres delinquentes? Qual a função do trabalho no cárcere para mulheres? Questões como essas e outras estavam presentes no final da década de 1930 e na década de 1940, primeiros tempos dos estabelecimentos prisionais voltados exclusivamente para mulheres no país.

Qual o cárcere ideal para mulheres, pensado pelos penienciaristas, desenhado pelos arquitetos e debatido nos meios penitenciários? Esta questão, que sintetiza as apontadas acima, será a pergunta principal a ser respondida no próximo capítu- 
lo. Antes os discursos e os debates em torno desses espaços serão considerados, uma vez que a proposta central do presente trabalho é elucidar como foi pensado o cárcere feminino nas suas origens no país e quais eram as principais propostas de organização dessas instituições que abrigariam mulheres desviantes de um determinado "dever ser" feminino, social e cientificamente construído. 


\section{Capitulo Quatro}

\section{PROJETOS E PRÁTICAS \\ DOS CÁRCERES FEMININOS}

não é o crime em si, ou a capacidade de delinqüir das mulheres que interessa ao regime penitenciário, mas o dever de segregá-las da sociedade, quando forem condenadas, dando-lhes a assistência compativel com seu sexo. Não se pleiteia para elas a impunidade, ou o deleite, ou a inércia na prisão, mas um regime de execução da pena que se adapte à sua condição de mulheres. Assim, o que se deve fazer não é transformar em paraiso as prisöes destinadas às mulheres que matam, roubam, injuriam, incendeiam, produzem ferimentos e praticam crimes como os homens, tendo a consciência dos seus atos, na medida em que a ciência admite a auto-determinação humana.

Lemos Britto, APB, 1942b, p.311

A citação de Lemos Britto transcrita acima traz elementos importantes para a análise dos primórdios dos estabelecimentos prisionais femininos nas décadas de 1930 e 1940. Isso porque, apesar de o autor deixar claro que o "regime penitenciário" se preocupava com a necessidade de segregação daquelas sentenciadas 
com a privação de liberdade, há preocupação explícita com o tratamento diferenciado voltado para as mulheres, que deveria ser "compatível com seu sexo". A fala oficial do presidente do Conselho Penitenciário remete a uma austeridade institucional legal que considera, em primeiro lugar, o cumprimento de uma ordem: retirar da sociedade os condenados por crimes. Mas a separação por sexo é uma forma de individualizar o cumprimento da pena, o que vai além da mera segregação. Sendo assim, não apenas a segregação estava em jogo, mas a forma como esta se daria. Afinal, o que seria atentar para o sexo e colocar em prática um regime compatível com este?

Lemos Britto logo refuta as regalias geralmente associadas ao "sexo frágil" - as mulheres não seriam tratadas como delicadas criaturas, recebendo tratamento brando e punição pró-forma. Sua colocação denota que não haveria uma leniência institucional, em se tratando de prisioneiras, mas uma adequação das regras prisionais às características próprias do sexo feminino. $\mathrm{O}$ que seria atentar para o sexo feminino em termos institucionais? Quais providências seriam tomadas pela instituição para abrigar corretamente as mulheres? Quais objetivos deveriam ser perseguidos nesses espaços? Haveria um projeto de reinserção específico para mulheres? Se sim, em que consistiria? Essa individualização do tratamento destinado às mulheres, da qual fala Lemos Britto, deveria ser observada desde a instituição de trabalho adequado para o sexo feminino, à criação de creches para os filhos das sentenciadas, passando pela arquitetura prisional, os uniformes, a administração.

$\mathrm{Na}$ revista $A$ Estrela há menção a uma visita surpresa feita pelo vereador Elizeu Alves à Penitenciária Central do Distrito Federal. Ao deixar por escrito suas impressões, o vereador frisou que as mulheres deveriam ser tratadas de maneira bem mais diferenciada do que pretendiam os penitenciaristas, colocando em xeque a visão de igualdade jurídica entre os sexos. A resposta d' A Estrela ao vereador ressalta a igualdade de todos perante a lei, e está afinada com o discurso de Lemos Britto transcrito acima, pois defende o tratamento diferenciado apenas na medida em que for necessário. Segundo a revista: 
naturalmente que a mulher, mesmo presa, é mulher! Dá-se-lhe, portanto, o tratamento que melhor se adapte ás condições especialíssimas do sexo, dispensando-as de deveres mais rigorosos exigidos aos condenados do sexo oposto. Somos testemunhas de que a mulher presa, na penitenciária ou no anexo de Bangu, recebe toda a assistência carinhosa que sua constituição física e moral condiciona. Não é razoável que o senhor Elizeu exija mais, argumentando com a Constituição da República, cuja perfectibilidade é baseada, principalmente, na igualdade de direitos, seja para Eva, seja para Adão... (AE, set/out de 1951, p. 34)

Tanto no discurso de Lemos Britto quanto na resposta de $A$ Estrela é possível notar, também, uma neutralidade que não está presente quando os penitenciaristas tratam da mulher criminosa. Quando em pauta as novas instituições, as falas de promiscuidade, os escalonamentos de diferentes tipos de criminosas, as menções às corrigíveis e incorrigíveis e às perigosas ou vítimas do acaso desaparecem, cedendo lugar a um discurso institucional que homogeiniza suas internas, transmitindo a ideia de que, uma vez na instituição, todas são iguais - todas são mulheres.

O crime em si aparece, na citação de Lemos Britto, como um ato preestabelecido que pode ser cometido tanto por homens quanto por mulheres, sujeitos de suas razões e responsáveis por seus atos. O jurista retoma o paradigma clássico segundo o qual o crime seria um ato de livre arbítrio, devendo o agente responder por ele de modo a pagar sua dívida para com a sociedade. A autodeterminação humana é um conceito tão metafísico como o próprio livre-arbítrio, e seu uso denota o quanto a escola clássica de Beccaria não havia abandonado de vez a prática prisional e, como ressaltado no primeiro capítulo, a própria legislação penal. Nesse contexto, cabe questionar, se no cárcere para mulheres havia lugar para positivismo criminológico inaugurado por Lombroso, ou se este aparecia com maior potência na delineação da figura delinqüente.

É interessante notar que o Direito Penal Clássico e a Antropologia Criminal estavam presentes no CP de 1940, bem como nos discursos de penitenciaristas e operadores do direito, tencionando em pontos chave, como aqueles em torno da 
responsabilidade penal do sujeito delinquente, dos contrastes entre o determinismo biológico e o livre-arbítrio metafísico, e das propostas de estabelecimentos adequados para o encarceramento dos sujeitos delinqüentes. Há um paradoxo chave entre as duas Escolas: enquanto o Direito Penal Clássico privilegiava o sujeito como centro decisório, prevalecendo a ideia de que o sujeito é senhor das suas vontades, e quem decide praticar o ato criminoso, a Antropologia Criminal pensava o sujeito como um doente, autor do crime porque vítima de uma patologia.

No entanto, quando em análise a construção dos cárceres femininos no país, é possível apontar uma convivência entre esses pensamentos criminológicos de maneira menos paradoxal do que se poderia supor. Isso porque, cada um deles, a seu modo, prevê o cárcere como espaço de cura, seja do corpo, como no caso dos antropólogos criminais, seja moral, como no caso dos clássicos. Para o iluminismo a prisão era um espaço para remissão, expiação da culpa, arrependimento, local para os condenados repensarem suas vidas, seu crime, para "curar suas almas"; para a Antropologia Criminal, a pena era a cura da doença, da degenerescência. Fazendo dialogarem essas duas propostas cabe a seguinte questão: por que cuidar da alma difere do cuidar do corpo? Até que ponto essas propostas não são mais convergentes que paradoxais? Por que é paradoxal pensar a cura moral e a cura física? Cura como algo que deve ser retomado em sua normalidade. A reflexão, a cura, a higiene, a disciplina parecem não deixar de ser elementos redentores. O espaço da prisão como espaço de redenção e recomposição de mulheres para ocupar um lugar social atribuído ao feminino mesclava ensinamentos dessas escolas, em uma peculiar tarefa de curar corpos e almas, normalizando-os dentro de um padrão de feminino.

\section{PRIMEIROS TEMPOS}

Preocupação constante desde a década de 1920, o encarceramento feminino estava, por razões diversas, cada vez mais na ordem do dia para os penitenciaristas. Inserido em um contexto mais amplo, em uma época de intensa ebulição penitenciária, como foram as décadas de 1930 e 1940, quando reformas prisionais eram 
pensadas e executadas, o Conselho Penitenciário do Distrito Federal, bem como os Conselhos de alguns estados, tornaram-se órgãos ativos. A institucionalização do país acelerava-se; todo o sistema penal se reformulava haja vista a promulgação do CP em 1940 e do CPP em 1941; havia um projeto de cárcere modelo bem definido, que previa a pena individualizada com a função principal de ressocialização. $\mathrm{O}$ cárcere para mulheres surgiu, assim, como outras instituições, sob a égide de compor um novo tempo penitenciário.

O CP de 1940 e os debates anteriores a ele contribuíram especialmente para esse "entusiasmo" penitenciário, uma vez que o texto do Código previa, em diferentes momentos, a individualização da pena, bem como a tratava como "defesa social humana, mas eficiente e justaposta, através de sanções reparadoras, porem, intimidantes" (APB, 1940, p. 32). Roberto Lyra, membro da comissão revisora do Código Penal, ressalta em artigo dos Arquivos Penitenciários do Brasil que a legislação penal não pode se pautar pelos estados atrasados, mas sim deve "nivelar pelo alto, forçando o avanço". Nas palavras do jurista, "sempre que se cogita a elaboração de um Código Penal digno do Brasil, os descrentes lembram o desaparelhamento penitenciário e a falta de magistratura especializada, sobretudo nos Estados" (APB, 1940, p. 29). Para Lyra uma legislação que forçasse a reforma penitenciária era positiva, a medida que possibilitaria ao Brasil finalmente começar a investir na modernização carcerária.

Em especial o parágrafo $2^{\circ}$ do artigo 29 do CP de 1940 acelerou a construção de estabelecimentos prisionais para mulheres, uma vez que o texto era taxativo ao afirmar que "as mulheres cumprem pena em estabelecimento especial, ou, à falta, em secção adequada da penitenciária ou prisão comum, ficando sujeita a trabalho interno". A partir da promulgação do CP, o estado da Federação que não atentasse para o aprisionamento feminino, criando um novo espaço para reclusas, ou adequando um já existente, estaria agindo contra a lei.

Soma-se a isso a pressão dos penitenciaristas e do Conselho Penitenciário do Distrito Federal que, há décadas, chamava a atenção para a situação carcerária feminina. As razões dadas para a separação entre homens e mulheres eram inúmeras, sendo as principais a promiscuidade sexual em ambientes nos quais conviviam jun- 
tos; a precariedade dos espaços que sobravam para as mulheres nas penitenciárias e cadeias; e a promiscuidade das próprias detentas entre si, pois além dos possíveis envolvimentos sexuais entre elas, e de estarem juntas condenadas e mulheres aguardando julgamento, eram presas na mesma cela "mulheres honestas" e as "criminosas mais sórdidas".

O atraso do Brasil em relação a outros países latino-americanos que já tinham seus presídios femininos também representava mais uma pressão importante: o Chile, desde 1864, delegou o cuidado das primeiras casas de correção voltadas para as mulheres à Congregação do Bom Pastor d'Angers; o Peru o fez em 1871 e a Argentina em meados da década de 1880. A proximidade dos penitenciaristas nacionais de seus pares latino-americanos permitia um intercâmbio de idéias e de experiências sobre a situação prisional dos países, em especial nos congressos de criminologia. No Segundo Congresso Latino-Americano de Criminologia, ocorrido em 1941, por exemplo, temas como reforma prisional atendendo aos princípios democráticos; união criminológica latino-americana; importância do serviço social como colaborador indispensável das ciências penais; adoção de pena de tempo indeterminado em casos de periculosidade extrema do apenado; substituição de penas privativas de liberdade de curta duração por outras medidas; tratamento aos perversos conforme sua periculosidade; superação da ideia de descendência criminal; inclusão da psicanálise entre os sistemas de estudo, repressão e profilaxia do delito; e cumprimento da pena privativa de liberdade em local higiênico, com possibilidade de trabalho e disciplina foram centrais nas discussões desse foro. Publicadas no Arquivos Penitenciários do Brasil do $1^{\circ}$ trimestre de 1941, tais conclusões são representativas do debate penitenciário latino-americano da época, uma vez que resumem as principais discussões ocorridas durante a Conferência, ressaltando os arremates comuns aos quais chegaram os países em relação aos assuntos em pauta. É possível notar, pelos temas, uma preocupação geral em superar práticas e classificações ultrapassadas, e investir em uma modernidade punitiva.

Diante desse cenário, nos últimos anos da década de 1930 e nos primeiros da década de 1940 surgiram os primeiros estabelecimentos prisionais brasileiros 
para o recolhimento exclusivamente de mulheres. Tendo sido alguns estabelecidos em edifícios adaptados para recebê-las, e outros instalados em prédios construídos para tal fim, é possível verificar que as semelhanças entre essas instituições são maiores que as suas diferenças. A administração das Freiras da Irmandade do Bom Pastor d'Angers, as funções esperadas da pena, o tipo de trabalho realizado pelas detentas e o cotidiano prisional são alguns exemplos de similitude entre os primeiros presídios femininos. Nas manifestações de penitenciaristas e visitantes a respeito desses estabelecimentos, é possível apontar impressóes muito parecidas mesmo em se tratando de presídios distintos, o que aponta para uma sintonia entre essas instituições.

No ano de 1937 foi criado, na cidade de Porto Alegre, o Reformatório de Mulheres Criminosas, que posteriormente passou a ser chamado Instituto Feminino de Readaptação Social, primeira instituição prisional brasileira voltada especificamente para o aprisionamento de mulheres ${ }^{76}$. Apesar de não ocupar edifício construído especificamente para abrigar mulheres presas, mas um "prédio senhorial" no centro da cidade, foi a primeira vez que mulheres foram encarceradas no Brasil em espaço totalmente apartado do presídio masculino. Visto como um grande passo no sentido da modernização prisional no estado, o Instituto, de acordo com matéria publicada no jornal gaúcho Correio do Povo, e reproduzida nas páginas dos Arquivos Penitenciários do Brasil, permitiu que as "condições de vida na prisão [fossem] mais compatíveis com os modernos princípios da Criminologia e com a 'velha' dignidade humana”. A matéria ressalta, ainda, que:

desde 1937, toda mulher condenada pela justiça do Rio Grande do Sul cumpre a pena que lhe foi imposta nesse Reformatório. Ainda não é a solução, mas foi um largo passo no caminho de obstáculos que se deve percorrer até conseguir-se a integral solução do problema penitenciário do Estado (APB, 1942d, p. 259).

$76 \quad$ No decreto estadual No 7601 de 05 de dezembro de 1938, publicado pelo Governo do Rio Grande do Sul, com o objetivo de "dar nova organização à Polícia de Carreira do Estado do Rio Grande do Sul" há menção explícita, em seu artigo 108, ao Reformatório de Mulheres Criminosas, que deveria estar subordinado à Diretoria de Presídios e Anexos. 
Já em 1941 o decreto 12.116 de 11 de agosto instituía o Presídio de Mulheres de São Paulo, que nasceu, assim como o Instituto do Rio Grande do Sul, de maneira improvisada, pois foi instalado na antiga residência dos diretores no terreno da Penitenciária do Estado, no bairro do Carandiru. Apesar de ocupar casa já existente, o decreto previa que o imóvel fosse "previamente adaptado" de modo a acolher apenas "mulheres definitivamente condenadas".

Em 08 de novembro de 1942 foi inaugurada no Rio de Janeiro a Penitenciária de Mulheres do Distrito Federal, criada por meio do decreto 3.971, de 24 de dezembro de 1941. Construída especialmente para ser um estabelecimento prisional feminino, ergueu-se em terreno que, segundo informação presente nos Arquivos Penitenciários do Brasil um (...) "industrial e capitalista Brasileiro, conhecido por seus gestos de filantropia, doou, como presidente da Companhia Industrial do Brasil, em uma vasta área de terras planas, situada num dos melhores pontos de Bangu, na Capital Federal" (APB, 1940, p.267). Foi construída e inaugurada juntamente com o Sanatório Penal para Tuberculosos. Em discurso proferido na ocasião da inauguração desses dois estabelecimentos, Lemos Britto, então presidente do Conselho Penitenciário do Distrito Federal, frisou que, ao abrir

(...) a todos os presentes as portas das penitenciárias de mulheres e do sanatório penal para tuberculosos onde, sem luxo, que seria irritante, e sem demasias incompatíveis com a função social da pena, o Estado poderá aparecer perante a sociedade como uma organização que não foge a seus deveres, e que para cumpri-los não rompe com os sentimentos de simpatia e de solidariedade humana (APB, 1942d, p.10)

Ao mencionar a importância das inaugurações da Penitenciária de Mulheres e do Sanatório Penal, Lemos Britto retoma o passado para mostrar a "evolução penitenciária" que estava em curso no país e, em especial, na Capital Federal. Em suas palavras: 
para dar o significado destes estabelecimentos basta realçar o que era até ontem, dia 08 de novembro de 1942, na capital do Brasil, o alojamento das mulheres criminosas postas sob a tutela e proteção do Estado, e o que tem sido, através de mais de um século da nossa vida como nação soberana, o tratamento dispensado aos condenados; ali, uma dependência de rés do chão, acanhada, úmida e mal iluminada de um presídio de homens, em condições tais que todo devotamento e boa vontade dos respectivos diretores pouco podiam fazer para lhes suavisar os sofrimentos, sofrimentos mais para lamentar quando se tratavam de mulheres de boa condição social atiradas à promiscuidade daquela inadjetivável prisão (APB, 1942d, p.10).

Menções a outros estabelecimentos femininos que deveriam funcionar em um futuro próximo aparecem nos documentos pesquisados. No ano de 1939 o decreto 11.214, de 06 de Fevereiro, que organizava o serviço penitenciário do Estado da Bahia, previa a criação de um reformatório para mulheres criminosas, que deveria funcionar nos dois primeiros pavilhões de oficinas da própria penitenciária. $\mathrm{O}$ baixíssimo número de mulheres condenadas no estado da Bahia, bem como a falta de dinheiro, justificavam o aproveitamento de espaço no prédio para o estabelecimento do reformatório (APB, 1942d, pp. 309 e 310). A principal exigência era que houvesse a certeza de completa separação entre o espaço ocupado pelos homens e pelas mulheres. A solução temporária previa que:

o reformatório de mulheres ficará, pois, sob a mesma direção da detenção, designando-se apenas algumas guardiãs encarregadas dos serviços presentemente a cargo dos homens, na promiscuidade do indefensável presídio em que se encontram juntamente com os criminosos do outro sexo. Esta é a única solução viável, dadas as possibilidades financeiras do Estado, a não ser que se pudesse apelar para alguma ordem religiosa, em que as irmãs tomassem aos seus cuidados, como acontece na República Argentina e em outros países, as referidas mulheres, postas sob ação da justiça, mediante certas condições e subvenções pagas pelos cofres públicos (APB, 1941b, p.324). 
Já nos Arquivos Penitenciários do Brasil do $2^{\circ}$ e $3^{\circ}$ trimestre de 1941, aparece uma menção à inauguração, no Presídio de Pernambuco, de um pavilhão destinado às mulheres criminosas que recebeu o nome de "Prisão de Mulheres" (p. 144). Roberto Lyra, em artigo de 1940, cita inúmeras instituições prisionais em construção no país. Dentre elas, especificamente sobre as femininas, realça, além da já mencionada Penitenciária de Mulheres, em Bangu, a Penitenciária para Mulheres de Santa Catarina. Segundo o autor todas essas instituições em construção garantiriam a execução correta do novo $\mathrm{CP}$.

A partir do momento em que os estabelecimentos femininos saem do papel, algumas perguntas devem ser feitas para buscar compreender como estas instituições se encaixavam em um cenário político, criminológico e social específico do momento em questão. Como se ergueu o cárcere para mulheres em um período no qual se esperava posturas específicas de acordo com normativas de um "dever ser" feminino? Em que medida os tipos de criminosa delieneados no período eram contemplados por um cárcere voltado para a sua correção? Em que consistia essa correção?

\section{A CONGREGAÇÃO DE NOSSA SENHORA DA CARIDADE DO BOM PASTOR D' ANGERS}

Compreender a história, a missão e o funcionamento da Irmandade Nossa Senhora da Caridade do Bom Pastor d' Angers, responsável pela administração dos primeiros presídios femininos no Brasil, é de suma importância para entender não só a estruturação do cárcere para mulheres no país e o papel dele esperado, mas também para compreender o lugar por ele ocupado no período. $\mathrm{O}$ material de pesquisa coletado sobre a Irmandade se resume principalmente a textos publicados pela própria Congregação, informações contidas em sites ${ }^{77}$ da Congregação de diferentes países e entrevista realizada com a Irmã Zulma do Amaral Goulart. O conteúdo reuni-

77 Sites consultados: www.goodshepherdsisters.org; http://catholique-angers.cef.fr; http://www.buonpastoreint.org/ 
do nesses documentos e entrevista traz a história que suas autoras selecionaram para contar, sendo uma expressão da maneira como a própria Instituição se vê e quer ser vista. O modo como a Instituição se mostra foi a forma encontrada de contar a sua história e destacar o que há de mais interessante para a presente pesquisa.

Marie Dominique Poinsenet - autora de livros religiosos e biógrafa de personagens da história católica, como Santa Tereza d' Ávila - em seu livro Nada Impossivel ao Amor, traduzido do francês para o português pela Irmã Margarida de Moraes Campos, conta a história das origens da Irmandade Nossa Senhora da Caridade do Bom Pastor d'Angers por meio da biografia de sua fundadora, Madre Maria Eufrásia Pelletier. A autora utiliza como fonte bibliográfica, dentre outras, atas do Instituito de Nossa Senhora da Caridade do Bom Pastor d'Angers, escritos e partes do processo de canonização da Madre fundadora. Já a obra da Irmã Margarida de Moraes Campos intitulada A Congregação do Bom Pastor na Província Sul do Brasil pinceladas históricas, conta a história da Congregação no país, e apresenta versões das Irmãs que mostram outro lado dos convênios firmados com os estados para a administração dos presídios de mulheres, bem como apontam conflitos não explicitados nos periódicos e outros documentos pesquisados.

Apesar do tom romanceado e da parcialidade de suas autoras, os trabalhos, além de apresentar dados históricos importantes sobre a Congregação, mostram seu ethos, fundado na doação ao próximo, no enfrentamento de dificuldades, no sacrifício para a salvação, na superação dos obstáculos e na ideia de que a misericórdia divina se obtém por meio do sacrifício, da doação e do desapego. O tom destes trabalhos, muito tem a dizer sobre a filosofia da Congregação e a maneira de vida das ordenadas. As repetições incansáveis, nas duas obras, de algumas máximas proferidas pela fundadora da Congregação, como "nosso instituto fundou-se sobre a cruz" e "nada impossível ao amor", são exemplos dos lemas de sacrifício e auto doação privilegiados pela Ordem. Com a lente das irmãs e de simpatizantes da Congregação foram redigidos os documentos pesquisados e, é a partir deles que se buscará reconstituir partes dessa história e analisar, juntamente com dados sobre os presídios brasileiros, a presença das Irmãs nesses estabelecimentos. 
O Instituto Bom Pastor de Angers foi fundado na cidade de Angers na França, em 1829, com o objetivo de cuidar de "jovens, que o mundo, de alguma forma, seduziu" (POINSENET, 1968, p. 73). Resultado do "empréstimo" de irmãs do Instituto Nossa Senhora da Caridade, estabelecido em diversas cidades francesas, a nova ordem, que nasceu em Angers, teve como fundadora a Madre Maria Eufrásia Pelletier, oriunda da Congregação de Nossa Senhora da Caridade da cidade de Tours. No ano de 1838, a Ordem recebeu o nome definitivo de Nossa Senhora da Caridade do Bom Pastor d'Angers, uma junção das alcunhas do Instituto recém fundado e da Congregação de origem de sua fundadora. Nascida no ano de 1796, a Irmã foi a principal mentora e incentivadora da Congregação d' Angers, sendo responsável pela disseminação dessa Ordem pelos cinco continentes (POINSENET, 1968).

A principal missão do Instituto Nossa Senhora da Caridade do Bom Pastor d'Angers é a "salvação das almas" e a "cura moral" de meninas e mulheres em estado de abandono material e moral. "Cooperar com Deus na salvação das almas" é a vocação primeira das Irmãs que fazem voto de pobreza ao vestir o hábito e prometem se dedicar à reeducação e reabilitação das "desafortunadas" por meio da moral cristã. As palavras de Jesus de que "os sãos não têm necessidade de médico, mas sim os doentes" são reiteradas desde a fundação da Congregação, de modo a justificar e esclarecer o trabalho realizado pelas Irmãs.

Passagens bíblicas nas quais Jesus perdoa mulheres pecadoras servem como metáforas para o trabalho realizado pela Congregação Nossa Senhora da Caridade e posteriormente pelas Irmãs de Nossa Senhora da Caridade do Bom Pastor d'Angers, de levar mulheres pecadoras ou perdidas ao encontro de Deus (POINSENET, 1968, p. 36). No Evangelho de Lucas 7-8 (p. 1810), há uma parábola chamada $A$ pecadora perdoada e que ama, que narra passagem na qual Jesus perdoa os pecados de uma mulher pecadora que demonstrou seu profundo amor e seu respeito por ele. A função das Irmãs de permitir o encontro de suas "reeducandas" com Deus é explicitada, algumas vezes, por meio desta metáfora. Apesar de não serem elas responsáveis pelo 
perdão, elas proporcionam e facilitam o encontro dessas meninas e mulheres "moralmente abandonadas" com Deus para que este possa perdoá-las. Se todas as pessoas têm em si, de acordo com a doutrina católica, o potencial do arrependimento e Deus o perdão ilimitado, as Irmãs do Bom Pastor d'Angers buscam promover o arrependimento das que pecaram, de modo que elas possam obter o perdão divino.

Não são apenas aquelas em conflito com a lei as "ovelhas" da Irmandade, mas, mulheres desamparadas socialmente, sem família, sem trabalho honesto, sem proteção, prostituídas e perdidas. Em entrevista realizada em janeiro de $2011 \mathrm{com}$ a Irmã Zulma do Amaral Goulart - que foi diretora da Penitenciária Feminina de Tremembé, fundada na década de 1960, e diretora das presas na Penitenciária de Mulheres de Porto Alegre - ela ressaltou que o Carisma da Congregação é de misericórdia, para auxiliar aquelas que mais precisam. Usou a seguinte metáfora para caracterizar o público alvo e o trabalho: "sabe um vestido usado, gasto, que ninguém quer mais? Pois é, nós o costuramos, o consertamos, o aceitamos”.

De acordo com Poinsenet, o Padre Breton, um dos responsáveis pela fundação da Congregação, no dia da chegada das Irmãs de Nossa Senhora da Caridade à cidade de Angers, no ano de 1829, bradava pelas ruas decadentes, ao lado das Irmãs: "venham com estas senhoras todos os que vivem afastados de Deus!" (POINSENET, 1968, p. 71). A ideia de que Jesus veio à terra para chamar que se juntassem a ele não os justos, mas os pecadores é ressaltada constantemente nas obras pesquisadas.

Poinsenet narra a ocasião da chegada, em 1853, de trinta e oito jovens transferidas do Quarteirão Correcional da Casa Central de Rennes à Colonia Agricola das Jovens Detidas de Angers, dirigida pelas Irmãs, ressaltando as palavras de Madre Pelletier, segundo a qual:

no princípio pareciam tristes e tímidas. Logo, porém, que se viram diante do fogo de lenha que crepitava no grande fogão da cozinha, nossos passarinhos puseram-se a gorjear. Servimo-lhes sopa bem quente, carne, vinho etc., etc. Então seus corações se expandiram: havia muito tempo que não tinham semelhante festim! No dia seguinte nova surpresa: 
as roupas da prisão foram trocadas pelos vestidos que vocês confeccionaram com tanta solicitude e caridade. Olhavam-se umas para as outras nada compreendendo desta metamorfose. Mas, coisa diferente foi quando as levamos para passear numa parte do sítio! Então, não estamos mais na prisão? Pergunta uma delas? (POINSENET, 1968, p. 166).

$\mathrm{O}$ oferecimento às mulheres de um lar, roupas femininas, alimentação farta e passeio, aparece em clara oposição ao que a prisão proporcionava. A Irmandade buscava assumir uma imagem de acolhimento e cuidado, não de trancafiamento e opressão. A ideia, ressaltada por Poinsenet, de que "o amor guarda com muito maior segurança do que as mais sólidas grades e ferrolhos das prisões aqueles que vêm a descobri-lo ou redescobri-lo”, tornou-se um lema da Congregação. O potencial salvador do amor que deveria ser dedicado pelas Irmãs às “pensionistas” é igualmente destacado por Poinsenet, segundo a qual,

é uma maravilha constatar o desenvolvimento dessas jovens nesse clima de amor. Não! Para elas não estava tudo perdido, desfeito, liquidado para sempre. Chegará aquele dia em que, fundando seu próprio lar, poderão dispensar a ternura afetuosa, o amor dedicado de que seu coração transbordava - inconscientemente, talvez (POINSENET, 1968, p. 168).

A noção de penitência está presente na Congregação desde sua fundação. $\mathrm{O}$ sofrimento pelo outro, a doação extremada, o voto de pobreza mostram que as Irmãs, assim como as "pensionistas", pagavam suas penitências e buscavam a redenção dos seus pecados. O "desabafo" da Madre Pelletier transcrito por Poinsenet ressalta não só o objetivo da Congregação, mas ilustra como a penitência está na sua origem:

sinto um ardor pela salvação das almas que me abrasa e me consome. A glória de Deus e a salvação das almas, eis minha vida (...). Oh! Se soubessem como eu temo ao considerar a possibilidade de faltar ao que devo a Deus e a todas as minhas filhas... Quanta necessidade tenho de orações! Que missão! Quando penso no que fazem os médicos para salvar a vida dos corpos, a quantos estudos se dedicam para esse fim, acuso-me, a mim 
mesma, censuro-me por não trabalhar tanto para salvar a vida das almas, infinitamente mais preciosas que os corpos. Para chegar a esse fim é preciso saber sofrer, suportar muitas privações e muitas penas...Sinto-me consumida de zelo quando medito em nossa vocação (POINSENET, 1968, p. 190).

No "desabafo" da Madre fundadora é possível destacar o conflito entre corpo e alma. A função das Irmãs não é salvar o corpo, como devem fazer os médicos, mas a alma, tarefa árdua, que requer o sofrimento daquelas que a fazem. A alma eterna é "infinitamente mais preciosa" que o corpo efêmero, necessitando, portanto, de mais cuidados, mais devoção e entrega. Curar a alma é ação que se dá pela entrega a Deus, pelo arrependimento dos pecados, pelo desejo e prática de uma vida cristã.

A potencialidade do discurso de salvação das almas femininas para a reconciliação e/ou aprendizado de uma vida cristã possivelmente justificou a rápida expansão da Congregação do Bom Pastor d'Angers pela Europa e demais continentes. O sucesso da multiplicação das Casas do Bom Pastor d'Angers pode ser creditado a duas razões principais: por um lado, desde a criação da Casa, Madre Pelletier visava à sua ampliação, objetivo que parece associado à própria fundação da Congregação; por outro, o papel desempenhado pelas Irmãs do Bom Pastor d' Angers seduzia governantes, religiosos e a população em geral, uma vez que elas atentavam para aquelas das quais ninguém queria cuidar, mas que cada vez mais apareciam como um incômodo nas cidades crescentes.

A máxima "nosso zelo é abraçar o mundo inteiro" repetida pela Madre fundadora, de fato surtia efeitos: durante as décadas de 1840, 1850 e 1860 foram abertas filiais em diversos países da Europa, como Alemanha, Inglaterra, Itália e Bélgica, bem como em países de outros continentes, como Estados Unidos, Canadá, Argélia, Egito, Índia, Chile e Austrália. No ano de 1858 existiam 92 Casas do Bom Pastor d'Angers, 1868 religiosas e 349 noviças. Em meados de 1860 já eram 110 Casas. De acordo com Poinsenet, Madre Pelletier certa vez ressaltara que: "quanto a mim, não quero mais que digam que sou francesa. Sou italiana, inglesa, 
alemã, espanhola, americana, africana, indiana. Sou de todos os países onde há almas a salvar" (POINSENET, 1968, p. 123).

A primeira Casa do Bom Pastor d'Angers na América Latina foi construída em Santiago do Chile, em 1857, tendo, logo em seguida, em 1860, sido inaugurada uma segunda casa em Valparaíso, no mesmo país. Segundo Poinsenet, na ocasião da inauguração de uma das casas, o Bispo de Valparaíso saudou as Irmãs do Bom Pastor d'Angers declarando que era grande o número de meninas que reclamavam seus cuidados, cujos trabalhos eram conhecidos no mundo todo (POINSENET, 1968, p. 124). Na década de 1920 na América Latina, além do Chile, havia Casas no Brasil, Paraguai, Uruguai e Argentina.

No mês de novembro de 1891 as Irmãs do Bom Pastor d'Angers fundaram sua primeira Casa no Brasil, na então capital federal, o Rio de Janeiro ${ }^{78}$. No ano de 1892 foi fundada a segunda Casa, na Bahia, e em 1893 teve início o noviciado brasileiro. No ano de 1897 foi aberta a Casa de São Paulo e em 1902 uma nova filial na cidade de Juiz de Fora. Em 1906 havia um total de quatro Casas e 35 religiosas no Brasil. Na década seguinte foram abertas duas Casas no sertão da Bahia, nas cidades de Barra e Caetité. Já nos anos 20 foram inauguradas filiais nas cidades de Belo Horizonte, Recife, Pelotas, Petrópolis e no estado do Ceará (CAMPOS, 1981).

Em 1924 as Irmãs do Bom Pastor d'Angers assumiram os cuidados das menores infratoras na cidade do Rio de Janeiro. Foi a primeira vez, desde que chegaram ao Brasil, que às Irmãs foi delegado um trabalho desse tipo. A Casa de Prevenção e Reforma, como passou a ser chamado o abrigo de menores após a entrada das Irmãs, deveria inicialmente abrigar 100 menores. A Irmã Margarida de Moraes Campos, responsável por escrever a história da Congregação no Brasil, ressalta que não foi fácil a adaptação das menores ao estilo de vida das Irmãs, sendo que estas também tiveram

\footnotetext{
78 Vale ressaltar que o trabalho da Igreja Católica com a educação de meninas e mulheres pobres, de modo a garantir a estas o aprendizado de tarefas femininas, no interior da ética Cristã, já era praticado no país, sendo notório o trabalho da Escola Doméstica Nossa Senhora do Amparo, fundada oficialmente em 1871, que tinha “(...) o propósito de educar, orientar e proteger meninas desvalidas e desamparadas da cidade de Petrópolis através de instrução laica e religiosa” (CUNHA, 2007, p. 384). Sobre os trabalhos realizados por esta Escola (e suas demais ramificações), ver CUNHA, 2007, pp. 384 a 396.
} 
muitas dificuldades em lidar com as menores. A autora transcreve trecho de uma carta na qual a Irmã assistente Maria do Amor Divino Fernandes Pinheiro relata as diffculdades que surgiram nos primeiros tempos da Casa de Prevenção e Reforma:

nossa fundação era um verdadeiro abrigo de revoltosas. Nossa luta começou desde a instalação da obra e durou mais de um mês. Fomos obrigados a despedir várias meninas que já estavam pervertidas demais e impediam a recuperação das companheiras. Dez entre elas eram doentes mentais. Com o certificado médico e ordem do juiz de menores, foram internadas no Asilo de Alienados. Quando menos se esperava surgia uma revolta na classe. A Me. Maria Rosa lutou corpo a corpo com uma destas pobres criaturas que quase mata uma de suas colegas. Estas cenas eram constantes. Todos temiam por nós. Entretanto permanecíamos sempre calmas e serenas. Deus concedeu-nos a força e a coragem necessárias para não nos deixarmos abater (Irmã Maria do Amor Divino Fernandes Pinheiro, Apud. CAMPOS, 1981, p. 109).

Mais uma vez sacrifício e doação aparecem como marca registrada da Congregação. $\mathrm{O}$ tom da carta reflete a posição da Ordem de sempre se mostrar resistente às adversidades e de enfrentá-las com coragem e fé. Presente desde a fundação da Ordem em Angers, esse discurso é inerente à Congregação. O lema repetido com exaustão: "nosso instituto fundou-se sobre a cruz" não só enobrecia o trabalho das Irmãs, como ressaltava o tamanho de sua doação à vocação. Nesse sentido, Lemos Britto, ao advogar pela administração das Irmãs no estabelecimento para Mulheres de Bangu, mostrava o trabalho realizado por elas ressaltando que:

as casas do Bom Pastor dividem-se geralmente em duas secções: a destinada a menores preservadas contra o mal e a corrupção e a consagrada às arrependidas ou penitentes. Em muitas cidades, porém, se lhes acrescenta, como em Buenos Aires, Montevidéu, Santiago do Chile, Porto Alegre, uma secção, a mais pesada do ponto de vista dos sacrifícios, que é a destinada às mulheres criminosas (APB, 1942d, p. 43). 
A função de administrar os estabelecimentos prisionais femininos brasileiros foi assumida pela Congregação do Bom Pastor d'Angers, que ficou por mais de trinta anos em alguns desses estabelecimentos. Sua tarefa de recuperar moralmente as condenadas era alardeada como a missão que deveria cumprir nesses espaços. A facilidade inicial de delegar às Irmãs o cuidado com as presas foi aproveitada pelos penitenciaristas que trabalharam a função da pena feminina em consonância com um discurso de recuperação. Assim, a presença das Irmãs do Bom Pastor d'Angers nos cárceres femininos foi possível graças à confluência de facilidades observadas pelos responsáveis por sua organização no país, como poderá ser observado a seguir.

\section{A PRESENÇA DAS IRMÃS DO BOM PASTOR D' ANGERS NOS CÁRCERES FEMININOS}

Como ressaltado anteriormente, a Congregação do Bom Pastor d'Angers rapidamente se alastrou pelos continentes. Com a missão de cuidar de mulheres desvalidas, as Irmãs assumiam diferentes missões nos países nos quais se estabeleciam, visando à cura moral de meninas e mulheres em situação de abandono, prostituição ou em confronto com a lei. Em alguns países latino americanos, como Argentina e Chile, as Irmãs do Bom Pastor d'Angers já estavam presentes nos cárceres femininos desde as últimas décadas do século XIX, fato, aliás, que serviu como motivação para os argumentos daqueles que eram favoráveis à administração das Irmãs. A experiência da Congregação no trato com as detentas era elemento importante que justificava a entrega dos cuidados dos cárceres femininos brasileiros a suas representantes.

Não apenas o trabalho realizado pelas Irmãs nos cárceres dos países vizinhos, mas também as facilidades em contratá-las foram levadas em conta pelos penitenciaristas e governantes brasileiros. Sendo assim, antes de tratar especificamente da presença das Irmãs nos estabelecimentos prisionais nacionais, vale ressaltar, ainda que brevemente, alguns aspectos de sua administração nos cárceres femininos chilenos e argentinos. 


\section{Chile e Argentina: pioneiros sul-americanos}

As historiadoras María José Correa Gómez (2005), em artigo sobre as discussões e reformas dos cárceres para mulheres, no Chile, e Lila M. Caimari (1997), que analisa o trabalho do Estado, da Igreja e dos patronatos na reabilitação das presas na cidade de Buenos Aires, tratam da presença das Irmãs do Bom Pastor d'Angers respectivamente, nos cárceres chilenos e argentinos. Cada novo cárcere ocupado pelas Irmãs era considerado uma nova filial da Irmandade, estabelecida com os mesmos objetivos originais de cuidado para com as desvalidas e trabalho de reeducação moral.

No Chile, desde 1864 as Irmãs do Bom Pastor d'Angers eram responsáveis pelo trabalho com as mulheres presas, com o objetivo de oferecer-lhes caminhos de redenção, transformando "vícios em virtudes" (GÓMEZ, 2005, pp. 13 e 14). A correção, que era baseada "na educação cristã, deveria reforçar o modelo de mulher/mãe, imagem situada como pedra angular que deveria sustentar e manter 'firme e imóvel' o edifício social" (GÓMEZ, 2005, p. 14). Com tarefas baseadas em funções típicas do universo feminino, como o cuidado com o lar e com a prole, as detentas deveriam se dedicar a (re) aprender os papéis sociais que a sua condição de mulheres thes exigia. No entanto as mulheres delinquentes rompiam com os papéis femininos que deveriam cumprir: ao contrário dos homens, de quem se esperava comportamentos violentos, próprios de sua natureza, das mulheres era esperada docilidade e ternura. Assim, a delinqüência masculina era explicada pelo excesso de violência inerente ao homem, e a transgressão feminina era enxergada como um pecado (GÓMEZ, 2005, p. 14).

$\mathrm{Na}$ medida em que as mulheres transgressoras eram vistas como pecadoras, que rompiam com um "dever ser" feminino, o trabalho das Irmãs de educá-las para uma vida sem pecados era considerado pelas autoridades uma tarefa peculiar, que só poderia ser realizada por elas. Havia igualmente um interesse do Estado em manter as Irmãs cuidando dos estabelecimentos prisionais femininos, uma vez que era pouco dispendioso para os cofres públicos. Ainda, de acordo com Gómez, os discursos que promoviam uma ideia de responsabilidade social vinculada à caridade católica justificavam o contrato firmado entre o Estado e a Congregação, argumento cômo- 
do para aqueles que pouco pagavam, pouco cobravam e delegavam às Irmãs o cuidado para com as presas (GÓMEZ, 2005, p. 14).

A principal função atribuída à pena era a reabilitação, tarefa que deveria ser realizada pelas Irmãs, por meio do silêncio e da oração. A cargo da Congregação estavam todas as principais responsabilidades pelos cárceres femininos, como a administração, o cuidado com as internas, a relação com o Governo, e o cotidiano prisional (GÓMEZ, 2005, p. 16). Segundo Gómez, a autoridade das Irmãs era:

(...) exercida dentro do contexto de uma prisão, ou seja, um espaço de punição e supressão da liberdade, acompanhada por práticas ritualizadas que, por meio de ritmos repetitivos, extraíam a individualidade de cada presa, tentando dar forma a novos corpos e movimentos, criando mulheres contidas, silenciosas e cristãs (GÓMEZ, 2005, p. 17)

Instalações e infraestrutura péssimas marcaram as Casas de Correção femininas chilenas nos seus primeiros anos. As Irmãs eram as principais responsáveis também pela manutenção financeira dos estabelecimentos, sendo o financiamento estatal insuficiente para aprimorar ou mesmo manter o cárcere com um mínimo de dignidade. Relatos de assaltos, invasões e ameaças de fuga mostram a precariedade desses estabelecimentos e como o governo os colocava em segundo plano. Desde o início do século XX, críticas ao silêncio e pobreza que permeavam os cárceres femininos, bem como ao abandono por parte do Estado, passaram a aparecer na mídia chilena.

Se, por um lado, para um imaginário popular mais conservador, a nobre tarefa das Irmãs de buscar a reabilitação das encarceradas por meio da caridade e da salvação era fundamental para promover a reinserção social da mulher nos espaços a ela destinados, por outro lado havia críticos do funcionamento do sistema correcional praticado pelas Irmãs, uma vez que era distanciado das modernas práticas carcerárias, sendo, portanto, inadequado o método educacional das religiosas (GÓMEZ, 2005, p. 15, 17 e 18). Associações de mulheres chilenas criticavam, a partir principalmente da década de 1930, o sistema penitenciário feminino, chamando-o de colonial e atrasado. As críticas dessas mulheres iam desde a situação precária das Ca- 
sas Correcionais, ao método religioso rigoroso praticado pelas Irmãs, que, segundo elas, "desmulheralizava" as mulheres, tornando-as despersonalizadas, amorfas, inexpressivas, que só aprendiam a rezar e cultuar um Deus que para algumas nada representava (GÓMEZ, 2005, p. 19).

As associações chilenas de mulheres propunham que os cárceres femininos passassem para a tutela estatal, pois consideravam que as Irmãs não conseguiam cumprir o dever de reabilitação. Alem disso, propunham que as mulheres aprendessem ofícios que permitissem sua ressocialização na saída da prisão, tornando-se cabeleireiras, costureiras, lavadeiras e enfermeiras (GÓMEZ, 2005, 21). A implementação, em algumas Casas, de trabalhos de lavanderia e costura, pouco alterou o cenário punitivo feminino, pois as reformas necessárias eram muito mais amplas que o estabelecimento de oficinas pontuais de trabalho, uma vez que havia um "abismo" entre o que de fato as mulheres presas precisavam para sua possível reabilitação e o que o sistema prisional lhes proporcionava (GÓMEZ, 2005, p. 23). No entanto, mesmo com as reivindicações, as críticas ao trabalho das Irmãs e à postura do Estado, a administração dos cárceres femininos chilenos pelas Irmãs do Bom Pastor d'Angers durou mais de cem anos, encerrando-se apenas na década de 1970.

$\mathrm{Na}$ Argentina, desde 1890, foi delegada às Irmãs do Bom Pastor d'Angers a tarefa de cuidar dos estabelecimentos prisionais femininos. Em estudo sobre a presença das Irmãs nas prisões femininas argentinas, a historiadora Lila Caimari busca desvendar a aparente contradição de um governo conhecido por seu posicionamento positivista, científico e anticlerical, como foi o governo argentino no final do século XIX, permitir que uma ordem religiosa tomasse conta dos cárceres para mulheres no país. Segundo a autora, houve forte pressão por parte das lideranças religiosas e mulheres católicas influentes, mas foram, principalmente as seguintes razões que incentivaram o governo argentino a delegar ao Bom Pastor d'Angers a administração desses estabelecimentos: I) os perigos morais de deixar as mulheres nas mãos de administradores do sexo masculino; II) a necessidade de um staff feminino que pudesse não só trabalhar, mas também morar com as detentas; III) a ausência, na burocracia estatal, de mulheres capazes de cumprir essa função, e o longo tempo que o 
Estado levaria para contratar e treinar possíveis funcionárias; IV) o fato de as Irmãs morarem em conventos e estarem habituadas à vida de privação e às celas; V) a posição de autoridade que as Irmãs exerciam, tanto em relação às funcionárias, quanto em relação às presas; VI) o baixo custo que seria para o Estado a administração das Irmãs; VII) o fato de o aprisionamento feminino não justificar altos gastos governamentais; VIII) o fato de a criminalidade feminina ser vista como um problema de ordem moral, portanto, adequadamente endereçado às Irmãs.

Assim como no Chile, na Argentina não havia, por parte das Irmãs, uma preocupação em educar as mulheres para o moderno mundo do trabalho que se organizava do lado de fora dos cárceres. A principal preocupação era realizar um trabalho moral de redenção da alma e aprendizagem dos valores cristãos. Todo o trabalho que faziam, como a costura, o bordado e os trabalhos de lavanderia, no máximo as treinavam para tarefas domésticas nas suas casas ou em casas de família, mas não permitiam uma mudança estrutural que as colocasse no mercado de trabalho citadino. Tanto o Estado quanto as freiras concordavam em relação à vocação das mulheres pobres para cuidar das tarefas do lar (CAIMARI, 1997, p. 191)

De acordo com Caimari, as Irmãs mediam o sucesso de seu trabalho pelo número de detentas que conseguiam converter ao catolicismo: mulheres que "(...) foram começar famílias cristãs, fazer primeira comunhão ou ser batizadas, para que se confirmassem em sua fé" (CAIMARI, 1997, p. 192). A ex-interna perfeita seria aquela que representasse um modelo de gentileza, subserviência e humildade, e que seguisse a doutrina cristã.

A situação prisional feminina argentina em muito se parecia com a chilena: péssimas condições de encarceramento, poucos recursos, pouca contribuição estatal, superpopulação, convívio de mulheres perigosas com criminosas ocasionais (CAIMARI, 1997, p. 194; GÓMEZ, 2005). Tamanha era a precariedade dos cárceres argentinos que havia uma relutância dos operadores dos aparatos estatais em mandar as mulheres para a prisão. As poucas Casas para aprisionamento feminino, e o estado precário em que se encontravam, bem como a superlotação, justificavam o fato de muitos juízes abrandarem as penas femininas, condenarem 
menos as mulheres e/ou encaminhá-las para asilos religiosos (CAIMARI, 1997, pp.198 e 199).

Assim como no Chile, a administração das Irmãs se deu em meio a críticas. No início da década de 1930 foi criado, por estudantes de direito que se indignaram com a situação prisional feminina na Argentina, o Patronato de Recluidas y Liberadas, com o objetivo de aplicar aos cárceres as mais modernas recomendações da criminologia em relação à prevenção do crime e à reabilitação das presas e das egressas. Ensinar às mulheres uma profissão, que permitisse a elas trabalhar de maneira digna no retorno à sociedade, era parte de projeto de reinserção social e prevenção do crime traçado pelo Patronato. O grupo criticava a atuação das Irmãs, que se preocupavam principalmente com a salvação moral das reclusas, não as preparando para a reinserção no mundo do trabalho, ou mesmo para enfrentar as dificuldades com as quais poderiam se deparar fora do cárcere. Além disso, ressaltavam que a educação praticada pelas Irmãs não visava à formação de cidadãs, mas de cristãs. Caimari frisa que de acordo com um dos mentores do Patronato "a religião não só era inútil na regeneração moral das presas, mas também perigosa, uma vez que tendia a embasar a moralidade e o respeito à autoridade apenas em termos religiosos e não civis" (CAIMARI, 1997, p. 204).

O Patronato acusava as Irmãs de serem ultrapassadas e de viverem e educarem as detentas em um mundo absolutamente alheio à realidade, no qual prevalecia a oração e o binarismo entre o pecado e o perdão. As Irmãs representavam, assim, um grande obstáculo ao trabalho do Patronato, não só porque tinham objetivos completamente distintos entre si, mas também pelo fato do primeiro representar uma ameaça à administração e ao espaço ocupado pelas Irmãs. Apesar de sua insistência, os membros do Patronato não conseguiram grandes progressos, pois, além da resistência das Irmãs, não conseguiram o apoio do Estado, para quem era conveniente não ter preocupações com as mulheres presas, deixando-as nas mãos das Irmãs. Prova disso é o fato de que, em 1936, uma nova prisão de mulheres na província de Buenos Aires ter sido entregue aos cuidados das Irmãs do Bom Pastor d'Angers (CAIMARI, 1997, pp. 200 a 208). 
Diante do exposto, é possível notar que tanto o Chile quanto a Argentina vivenciaram experiências semelhantes em relação à edificação das prisões femininas e nos dois países houve convergências entre os objetivos, cotidiano e resistências a esses espaços. Ambos, na segunda metade do século XIX, contaram com a presença das Irmãs do Bom Pastor d'Angers na estruturação dos seus estabelecimentos prisionais para mulheres, sendo o dia a dia de orações e investimentos na recuperação moral das detentas a base do trabalho realizado pela Congregação. Igualmente, como ressaltado, não foi sem resistência que as Irmãs do Bom Pastor d'Angers administraram as casas correcionais para mulheres nesses países, uma vez que tanto na Argentina quanto no Chile, a partir principalmente da década de 1930, surgiram críticas profundas e relutâncias de diferentes grupos à entrega da administração dos cárceres destinados às mulheres às Irmãs. $\mathrm{O}$ fato de os trabalhos realizados pela Congregação não estarem de acordo com as tendências mais modernas da criminologia, bem como de haver negligência das Irmãs na promoção de uma reinserção social que realmente permitisse às mulheres egressas a ruptura com ciclos delitivos e de violência, eram os principais pontos criticados pelos grupos que se opunham à presença das Irmãs. Menos os lugares sociais ocupados pelas mulheres nas sociedades chilenas e argentinas, e mais a possibilidade das presas aprenderem ofícios e serem capazes de se sustentarem ao retornar à sociedade, moviam aqueles que criticavam a metodologia aplicada pelas Irmãs no trato com as presas. Como se deu a entrada das Irmãs como administradoras dos estabelecimentos prisionais femininos no Brasil? É possível apontar convergências entre os processos chileno, argentino e brasileiro? Qual o papel desempenhado pelas Irmãs no cotidiano prisional feminino brasileiro? Estas e outras questões guiarão os debates a seguir.

\section{Gerenciamento e tutela - as Irmãs nos estabelecimentos prisionais femininos brasileiros}

Apesar das Irmãs estarem no Brasil desde a segunda metade do século XIX, foi apenas no final da década de 1930 que a primeira penitenciária feminina brasileira ergueu-se, na cidade de Porto Alegre, no Rio Grande do Sul. Campos 
ressalta que desde os primeiros anos da Irmandade no Brasil a Superiora Provincial, Madre Xavier Novoa, desejava que a Congregação cuidasse das presas brasileiras, como já acontecia na América Latina, em países como Chile, Argentina e Peru (CAMPOS, 1981, p. 152). No entanto, foi apenas no final da década de 1930 que as conjunturas políticas e legislativas confluíram para que um primeiro passo fosse dado nesse sentido.

A criação dessa primeira penitenciária para mulheres, em 1937 em Porto Alegre, coincide com um acordo realizado entre a Congregação e o Governo do Estado do Rio Grande do Sul. As Irmãs do Bom Pastor d'Angers estiveram na Base do Reformatório para Mulheres de Porto Alegre criado graças à garantia de que elas, que tinham experiência de mais de um século no cuidado com as mulheres desvalidas, iriam assumir a administração. Um texto do jornal Correio do Povo de Porto Alegre sobre este estabelecimento, publicado nos Arquivos Penitenciários do Brasil, justifica a entrega da administração às Irmãs, e fala do apoio oficial ao trabalho da Ordem:

a finalidade maior da Ordem não é propriamente a que tem exercido nesta capital: serviço carcerário ou guarda a mulheres criminosas. Muito mais complexa, a finalidade do seu trabalho em todo o mundo consiste em reconduzir à vida social, pela assistência e pela educação, as mulheres abandonadas e as mulheres decaídas. No mais amplo sentido, usando termos da Ordem, seu trabalho é a regeneração da mulher que foi jogada ou se lançou à margem da sociedade e da família. Para isso, conta a Ordem com normas de ação seguramente traçadas através dos seus trezentos anos (sic) de experiência em todo o mundo. Está claro que a execução dêsse delicado e complexo trabalho antes de tudo precisa de uma organização material e técnica de vulto. É isso que as Irmãs do Bom Pastor vão realizar aqui em Porto Alegre. Animadas pelo apôio oficial e popular que a sua obra no Reformatório tem merecido (...)" (APB, 1942d, pp. 260 e 261). 


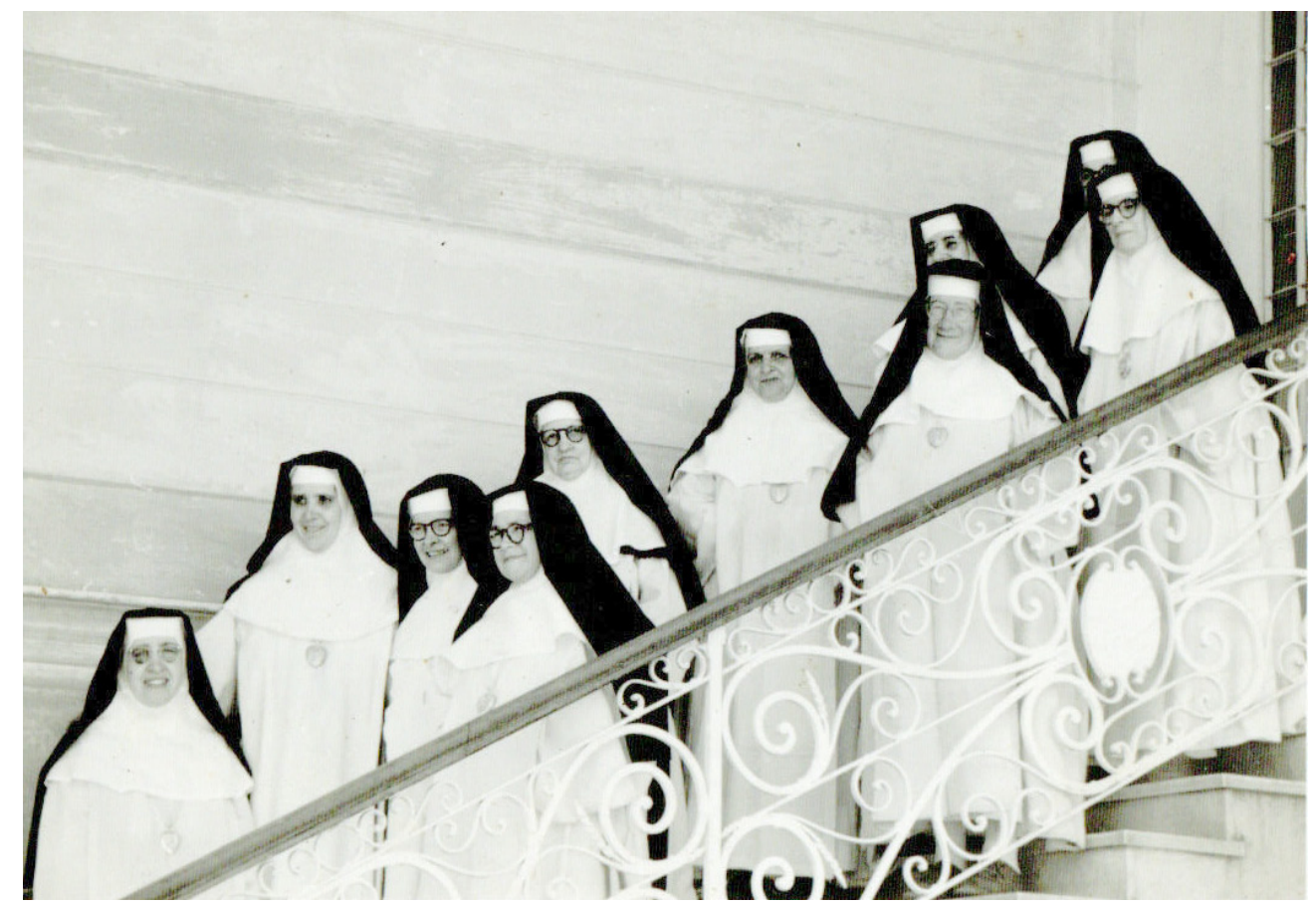

IRMÃS DO BOM PASTOR D’ANGERS NA ESCADARIA DO

PRESÍDIO DE MULHERES DE SÃO PAULO.

Conforme ressalta a Irmã Margarida de Moraes Campos, o General Flores da Cunha, então governador do estado, saudou as Irmãs com as seguintes palavras:

a prisão de mulheres, em miserabilíssimo estado, é uma espada que me atravessa a garganta. É, pois, com plena e inteira satisfação que acolho o Bom Pastor para transformá-la numa verdadeira escola de reforma, de regeneração e de educação moral (General Flores da Cunha apud. CAMPOS, 1981, p. 154).

A opção pela administração das Irmãs nos estabelecimentos prisionais femininos possivelmente se deu por razões semelhantes às dos vizinhos Argentina e Chile. Não havia no Brasil, naquele momento, outro grupo de mulheres capaz de se dedicar ao trabalho com as presas, uma vez que eram ainda poucas as mulheres no mercado de trabalho e raras as funcionárias públicas, alocadas, em geral, em setores mais "femininos", como os escritórios. Conseguir um grupo de mulheres laicas dispostas a trabalhar com aquelas que se desviaram do seu papel social, consideradas 
por vezes perigosas, violentas, perdidas e/ou degeneradas seria uma tarefa das mais complexas. Ainda, o lugar ocupado pela mulher delinquente, como ressaltado anteriormente, era o do desvio dos papéis do feminino, dos excessos, da falta de recato, das rupturas morais, soando a proposta das Irmãs de salvação moral e educação para uma ética cristã a mais adequada para o trato com essas mulheres desviantes.

Lemos Britto, ao apresentar ao Ministro da Justiça duas propostas para a gerência da Penitenciária de Mulheres de Bangu, comenta as vantagens da administração religiosa das Irmãs frente as de uma administração laica:

senhor Ministro, tenho a honra de pedir a Vossa Excelência orientação, quanto à direção a que deveremos confiar a Colônia Reeducacional de Mulheres, para a imediata elaboração do respectivo regulamento. Duas opiniões se apresentam a êste respeito: a da direção laica e a de direção a cargo de Irmãs do Bom Pastor, especializadas neste serviço em alguns países. Cada qual delas tem por si argumentos valiosos. Pela última depõem a experiência dessa ordem, a simplicidade da organização administrativa, uma certa economia com o pessoal. Pela primeira, o respeito ao regime penitenciário em vigor, as necessidades da instrução e educação das reclusas nos moldes estabelecidos na Lei e no regulamento, a facilidade da fiscalização por parte do Conselho Penitenciário e a fé pública que devem ter as informações, calcadas em estudo individual de cada sentenciada para concessão do livramento condicional. Ainda mesmo confiando-se às veneráveis irmãs a direção e a administração do estabelecimento, forçoso será dar-lhes diversos auxiliares que serão funcionários públicos, como médico, farmacêutico, dentista, armazenista, escriturárias, cozinheira, guardas, de vez que a organização dos serviços públicos, as exigências do regime penitenciário e as relações a serem mantidas com o Conselho Penitenciário e a Justiça, impõem a existência de tais serventuários, com funções previamente definidas (...). Rogo, assim, a Vossa Excelência uma palavra orientadora para que possamos apressar o Regulamento da Referida Colônia, cujas obras estão sendo concluídas (APB, 1942d, pp.23 e 24).

É interessante notar como os argumentos em favor da administração laica podem ser incorporados pela administração das Irmãs. Ora, uma administração re- 
ligiosa não era contrária ao regime penitenciário em vigor; as Irmãs se propunham a realizar um trabalho educacional de reinserção social com as reclusas; subordinadas ao Estado, as Irmãs responderiam ao Conselho Penitenciário, órgão ligado ao Ministério da Justiça e Negócios Interiores, não havendo, a priori, entraves para a entrada do Conselho. Alem disso, a contratação dos funcionários alegada por Lemos Britto deveria se dar em ambos os casos, sendo, a contratação das Irmãs, como ele mesmo ressalta, mais econômica, pois além desses funcionários em comum, a administração laica exigiria um rol maior de funcionários que seria dispendioso ao Estado. O Ministro, sem maiores delongas, sem explicações das razões de sua escolha, respondeu brevemente a Lemos Britto, presidente do Conselho Penitenciário: “(...) deve ser preferida a segunda das soluções alvitradas, tendo as Irmãs do Bom Pastor d'Angers o auxílio dos funcionários que se tornarem necessários".

Em outro momento, Lemos Britto, ao fazer considerações em torno do ante-projeto de regulamento para o estabelecimento de mulheres de Bangu, posicionou-se claramente a favor da administração das Irmãs, destacando a função da Congregação de uma perspectiva religiosa. O presidente do Conselho Penitenciário deixa transparecer sua fé católica, ao usar as palavras de um autor não citado para demonstrar os "milagres" que a educação das Irmãs poderia proporcionar:

não careço repetir a história da gloriosa instituição católica, cujo fim altruístico um autor assim resume: trata-se nestas fundações de obras erguidas pelo sacrifício e para o sacrifício, se bem impulsionadas, sustentadas e premiadas por amor nobilíssimo e sem fim. De onde constituir cada qual delas uma vitória da graça sobre a natureza, do amor sobre o egoísmo, da Igreja sobre o mundo e de Cristo sobre o mal. Quero, todavia, lembrar que sua disseminação [da Congregação do Bom Pastor] pelas terras da América do Sul mostra bem as qualidades intrépidas destas religiosas no esforço quotidiano de reerguer almas transviadas e de formar, da massa informe da ignorância, dos vícios e dos crimes, caracteres elevados e consagrados à virtude, ao trabalho e à própria abnegação (APB, 1942d,p.43). 
A ideia de sacrifício e "fundação sobre a cruz", sempre ressaltada pelas Irmãs, está também presente nas palavras de Lemos Britto sobre a Congregação. A doação das Irmãs à sua difícil função de "salvar almas" é destacada pelo jurista, segundo o qual: "sabem elas que essa missão social e religiosa é muito difícil e complexa. Por vezes lhes custa, mesmo, momentos amargos ou risco de vida” (p. 43).

A revista $A$ Estrela, publicou palestra de Victório Caneppa sobre os serviços religiosos e morais nas prisões, irradiada pela Rádio Jornal do Brasil, em 02 de maio de 1951, na qual este ressaltava a importância do trabalho das Irmãs do Bom Pastor d’Angers na Penitenciária de Mulheres de Bangu. Em sua fala, é possível pontuar os mesmos argumentos de Lemos Britto, para quem a vocação das Irmãs era extremamente adequada ao trabalho com as detentas. Segundo Caneppa:

missão nobilíssima e voltada para Deus, o apostalado dessas quase santas criaturas encontra fundamento na ação da caridade, mas também, ao mesmo tempo, por necessidade, mantêm uma vida profundamente ligada a Deus na conviç̧ão de poder aparecer, cheias de fé, para acalmar essas criaturas presas, que por vezes se mostram desconfiadas e revoltadas. Esse é o verdadeiro e delicado trabalho de reeducação que só a ciência pedagógica-penitenciária, acompanhada das virtudes e talento dessas abnegadas Irmãs, pode encontrar bom êxito. Ai está pois a verdadeira influência da religião nas prisões. (AE, p. 37 e 44)

Tanto o documento firmado entre a Secretaria de Justiça do estado do Rio de Janeiro e a Congregação do Bom Pastor d'Angers, que cede às Irmãs a administração da Penitenciária de Mulheres de Bangu, de 1942; quanto o contrato consolidado entre a Congregação e a Secretaria de Justiça e Negócios do Interior de São Paulo, referente à contratação das Irmãs para a administração do Presídio de Mulheres do Carandiru, de 1946, elucidam os termos dessas parcerias. São documentos com cláusulas semelhantes que estabelecem, dentre outros, que os estados deveriam cobrir as despesas de alimentação, roupa de cama e lavanderia das Irmãs; fornecer habitação a elas; possibilitar a realização dos atos religiosos; bem como que as Irmãs deveriam receber um salário anual. 


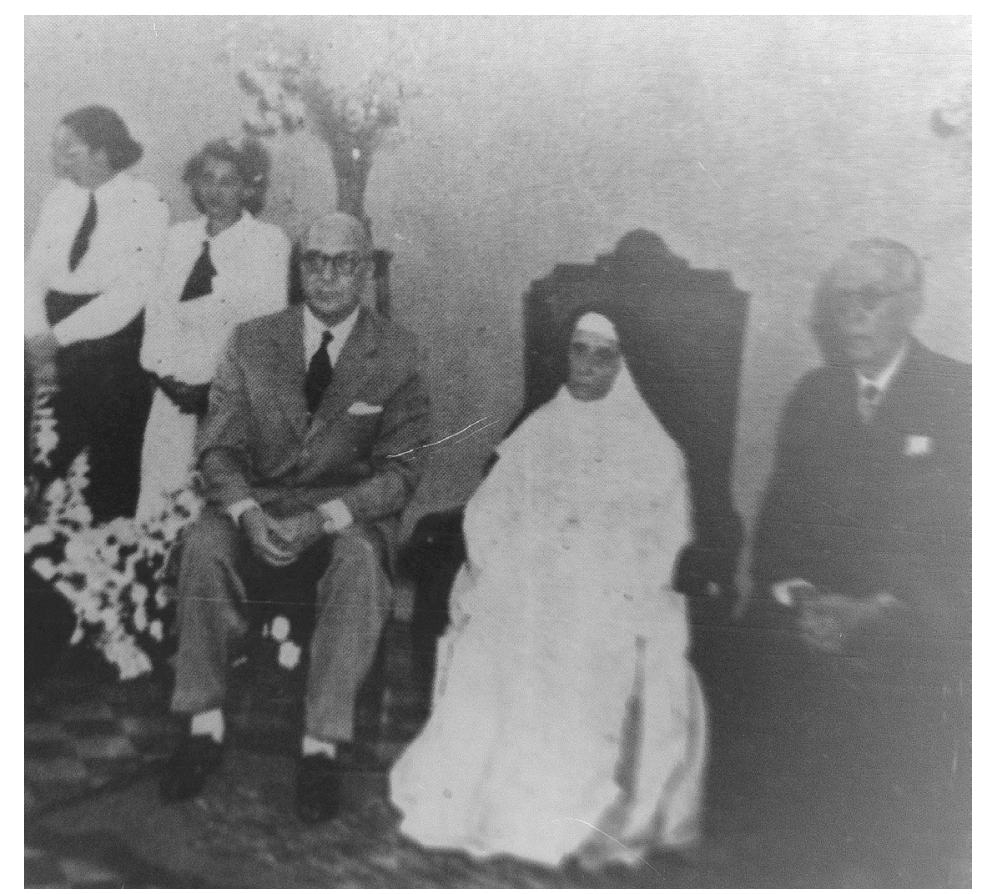

DA ESQUERDA PARA DIREITA - VICTÓRIO CANEPPA, MADRE SUPERIORA MARIA DE SÃO FRANCISCO DE ASSIS BRÍGIDO E LEMOS BRITTO. AO FUNDO INTERNAS DA PENITENCIÁRIA DE MULHERES DE BANGU (AE, JUNHO DE 1951, S/P).

A Primeira cláusula do contrato firmado no Rio de Janeiro, que trata das atribuições da Irmandade no cotidiano prisional, ressalta que, além de executar serviços de enfermagem as Irmãs deveriam "zelar pela educação, disciplina e trabalho das presas, e pela higiene e economia do Estabelecimento (...)” (APB, 1942d, p.56). Apesar da ampla atribuição conferida às Irmãs, elas estavam representadas no documento como "coadjuvantes" do serviço penitenciário. Isso porque a administração superior cabia à direção da Penitenciária Central do Distrito Federal, que poderia interferir no cotidiano prisional, inclusive ditando ordens e dando instruções sobre o serviço penitenciário praticado na Penitenciária de Mulberes. Além disso, cabia ao diretor da Penitenciária a autorização para a saída de presas do Estabelecimento, e ser consultado sobre a aplicação de medidas disciplinares às reclusas. Já o contrato de São Paulo frisava que as Irmãs deveriam "trabalhar pelo progresso moral e instrução doméstica das sentenciadas entregues aos seus cuidados”, bem como "encarregar-se da administração interna, ordem, asseio e economia do presídio e dar a cada uma das reclusas trabalho adequado (...)" (DO, 10 de julho de 1946, s/p). As- 
sim como o carioca, o documento paulista atribuía às Irmãs o cuidado cotidiano da Penitenciária de Mulheres e a missão de educá-las, acrescendo que a educação deveria estar focada, principalmente, no plano moral e no aprendizado de tarefas para o trabalho doméstico. Em São Paulo as Irmãs, da mesma forma que na Capital Federal, estavam submetidas à administração do estado, representada pela Diretoria Geral do Departamento de Presídios do estado, a quem deveriam submeter relatórios, averiguar o tratamento prisional vinculado às detentas e apresentar estatísticas mensais sobre a entrada e saída de sentenciadas.

A leitura dos contratos permite notar que havia uma institucionalização das tarefas das Irmãs, ao mesmo tempo em que havia o cuidado, por parte dos governos, de não perder o controle das Casas, mantendo uma administração superior. Portanto simultaneamente as Irmãs eram subordinadas ao diretor do complexo penitenciário, ou seja, a um poder central, e tinham uma autonomia significativa nos domínios do Presídio de Mulheres. Assim, apesar de terem bastante poder na administração dos espaços carcerários a elas concedidos, as Irmãs eram oficialmente auxiliares do poder central.

Elça Mendonça Lima, pesquisadora que na década de 1980 investigou a criação do presídio feminino do Rio de Janeiro, interpreta o contrato firmado entre as irmãs do Bom Pastor d'Angers e o governo do Distrito Federal como um atestado da submissão da Congregação a um poder central masculinizado. As Irmãs, apesar de certa autonomia que tinham na administração prisional, prestavam contas a um órgão público que contratualmente limitava sua atuação, uma vez que a palavra final em termos disciplinares e jurídicos era do Estado e não da Congregação. É possível se fazer uma analogia entre as funções dos homens e das mulheres no mundo de então: às Irmãs cabia a recuperação moral das detentas, o trabalho cotidiano de educar, bem como de economizar, tarefas que, em um lar, geralmente são femininas, enquanto ao Estado cabia lidar com a lei, com o castigo e com as questões práticas do mundo público, tarefas geralmente masculinas. Nas palavras de Lima: "as freiras se constituem em 'governantas' da casa e sua autonomia é reservada às tarefas 'domésticas' da instituição e à função auxiliar de observação e vigilância interna: o 'olho' auxiliar do poder" (LIMA, 1983, p. 57). 
No entanto, mais que uma limitação administrativa imposta pelo Estado, como aponta Lima, é possível pensar a concessão da administração das penitenciárias femininas às Irmãs como uma troca interessante para ambas as partes: a Irmandade, que desde as suas origens visava à sua expansão com a missão de salvar almas, contratava com o Estado que precisava aprisionar as mulheres delinqüentes em estabelecimento próprio. Em favor das Irmãs pesava o fato de serem mulheres disponíveis para esta tarefa; de terem experiência na lide com "mulheres perdidas"; de terem uma proposta de trabalho com as reclusas que agradava as autoridades, uma vez que visava à doutrinação de mulheres desviantes dentro de um "dever ser" cristão, que valorizava a família, a prole e o aprendizado de funções que estavam de acordo com um "dever ser" feminino; além disso, pouco custavam ao Estado. Já por parte da Congregação, assumir um estabelecimento prisional representava uma nova Casa da Irmandade no país - o que coincidia com a proposta originária de expansão pregada pela Madre fundadora - onde elas poderiam exercer a vocação principal de trabalhar com aquelas que, a seu ver, precisavam de salvação moral. Ambas as partes contratantes tinham vantagens que facilitavam a instauração do contrato. Tais vantagens se assemelhavam à contratação das Irmãs para os cuidados dos cárceres femininos argentinos, conforme já ressaltado anteriormente.

Nesse cenário é possível questionar de que maneira o Estado laico permitiu a administração de um estabelecimento público por uma congregação religiosa. Como, com a garantia constitucional de laicidade estatal, o Governo permitiu a presença das Irmãs nos primeiros institutos prisionais femininos no país? Trata-se de questão importante, em especial para se compreender as concepções de encarceramento feminino que habitavam o imaginário punitivo do período, bem como a função da religião no universo carcerário como um todo. 


\section{Presença da religião nos cárceres nacionais}

Desta vez nosso Diretor

Alegre conosco vai ficar,

Vendo carinho e amor

A todo castigo suplantar.

Um lar também já tivemos...

Por maior que seja o nosso crime,

O perdão dos homens merecemos,

Porque Deus - que é Deus - nos redime

Poema "pedrinha de sal", escrito e recitado pela presa no 370 , na ocasião da visita de Victório Caneppa à Penitenciária de Mulheres, AE, junho de 1951, s/p.

A aparente contradição entre o Estado laico, constitucionalmente garantido, e a administração das religiosas é resolvida quando se considera que não se tratava de um estado laico, mas da afirmação legal de um estado laico, o que são duas posturas distintas. A legislação pátria seguia as Constituições mais modernas dos países ocidentais, que encontrava na liberdade religiosa uma maneira não apenas de garantir formalmente a igualdade de todos, mas também de controlar as religióes existentes. Assim, pode-se afirmar que a garantia formal da liberdade religiosa não era sinônimo de Estado laico. Getúlio Vargas ${ }^{79}$ utilizou-se do simbolismo católico na tarefa de controlar as massas e organizar a nação, colocando-se no lugar de um grande pai capaz de proteger e cuidar dos mais desvalidos, possibilitando-lhes a salvação por meio da fé em Deus e nas instâncias estatais. Por mais paradoxal que possa parecer a utilização dessa figuração religiosa pelo líder político de um Estado formalmente laico, era com ela que cooptava a admiração e a obediência daqueles que buscava controlar.

A simbologia católica servia para dialogar com uma sociedade que compreendia essa estrutura, e que, principalmente, acreditava nela. A mediação entre Esta-

79 No poder de 1930 a 1934, como chefe do Governo Provisório; de 1934 a 1937 foi Presidente da República; entre 1937 e 1945 foi Presidente-ditador durante o Estado Novo, após golpe de Estado de 1937; e de 1951 a 1954 foi presidente eleito pelo voto direto. 
do e Povo era feita também pela religião, que doutrinava e controlava as classes sob uma ótica interessante ao Estado. A família cristã, nuclear, sadia, crente, e organizada era a célula social que permitiria o sucesso do plano civilizatório colocado em prática por Vargas. Nesse contexto, não é de se admirar que a religião católica estivesse presente em diferentes níveis da administração, e em instituições como as escolas, os hospitais e orfanatos, e que o recurso religioso fosse utilizado como instrumento de controle social. Além disso, a expansão da Igreja Católica, dos espaços da elite para as bases populares, fez estrategicamente parte do projeto desenvolvimentista de Vargas, que visava a controlar as classes menos favorecidas, temendo a ameaça da esquerda. Assim, foi a partir, principalmente, da década de 1930, que a Igreja passou a realizar no Brasil trabalhos de base entre a população de classes mais baixas, em parceria com o Estado.

De acordo com o historiador Ralph Della Cava, "o aspecto crucial da subsistência do catolicismo na sociedade brasileira é atribuído à sua qualidade de religião oficial de facto do Estado, da nação e das elites dominantes" (DELLA CAVA, 1975, p. 10). Em outras palavras, o fato de o catolicismo estar representado tanto nas instâncias de poder, por meio das elites, quanto numericamente, dentre os componentes da nação, garantia à Igreja uma série de privilégios e um grande poder político. Vargas, segundo o autor, sabia da importância da Igreja para a nação, já que se tratava de um país majoritariamente católico, tendo aprendido rapidamente a mantê-la ao lado de seu governo.

A pressão feita pela cúpula católica nacional, na década de 1930, para apoiar o novo presidente foi explícita, fato que fica claro na ocasião da inauguração da Estátua do Cristo Redentor, no morro do Corcovado no Rio de Janeiro, em 1931, na qual o cardeal Dom Sebastião Leme de Oliveira Cintra bradou publicamente que "ou o Estado... reconhece o Deus do povo, ou o povo não reconhecerá o Estado" (LEME, apud. DELLA CAVA, 1975, p. 15). As concessões feitas pelo governo Vargas às demandas da Igreja certamente se deram como forma de garantir o apoio da maioria da população ao novo presidente. Della Cava mostra o poder da Igreja ao ressaltar que: 
(...) embora constitucionalmente [constituição de 1934] se mantivesse a separação Igreja-Estado, as três concessões (que indicarei a seguir) levariam, na prática, em direção à união entre Nação e fé: primeiro o casamento religioso foi inteiramente reconhecido pela lei civil e o divórcio foi proibido; segundo foi facultada a educação religiosa em escolas públicas durante o período de aulas; terceiro foi permitido ao Estado financiar escolas da Igreja, seminários, hospitais e quaisquer outras atividades e instituições relacionadas e legalmente designadas como de 'interesse coletivo' (DELLA CAVA, 1975, p. 15).

A garantia de espaço para a Igreja junto aos serviços voltados para a sociedade permitia a esta se expandir em diferentes meios e exercer cargos de poder junto à população. E era justamente a relação estabelecida com a sociedade que fazia com que a Igreja ocupasse um lugar privilegiado junto ao Estado, já que tinha poder de influenciar não apenas os fiéis, mas também aqueles que dela dependiam em alguma medida, como os beneficiários de suas ações sociais. Assim, era conveniente ao Estado relacionar-se com a Igreja e vice versa, pois o poder concedido ao serviço social católico permitia à Igreja aproximar-se daqueles que a fortalecia, e, portanto, isto lhe possibilitava negociar com o Estado e pressioná-lo. Quanto para o Estado, era importante relacionar-se com esta instituição que exercia influência sobre aqueles que era preciso controlar de alguma forma.

Assim como nas escolas, hospitais e orfanatos, a religião católica também estava presente no cotidiano carcerário no período pesquisado. Não são raras as menções à religião e aos seus benefícios, nas falas, análises e reflexões dos penitenciaristas, que enxergavam a crença nos ensinamentos religiosos como possibilidades de salvação daqueles que haviam entrado em conflito com a lei. Apesar de dialogarem com a ciência e com as teorias criminológicas que se pressupunham neutras e científicas, como a Antropologia Criminal, esses penitenciaristas recorriam à religião como instrumento de transformação da moral do sentenciado, recurso que para muitos não atrapalhava o trabalho de tratamento físico e de disciplina voltados ao encarcerado, mas, pelo contrário, complementava-o. 
Não foi apenas nos presídios femininos que a religião se fez presente. Por exemplo, diferentes volumes da revista $A$ Estrela narram a constante participação de entidades religiosas na Penitenciária Central do Distrito Federal. Em nota sobre o "dia do encarcerado", publicada na revista, é possível perceber não só a presença de distintas religiões cristãs nas celebrações, mas principalmente a importância dada pelo periódico à presença desses vários credos. A doutrina cristã da salvação, presente nos discursos religiosos, reforçava a importância desse pensamento na educação moral dos sentenciados. De acordo com a nota:

depois do café começou a celebração dos cultos religiosos; no auditório reuniram-se os presbiterianos, os Batistas da igreja de São Francisco Xavier, da Igreja Metodista de Vila Izabel e da Primeira Igreja Batista do Rio de Janeiro, representados por ilustres reverendos que vieram trazer aos adeptos a palavra confortadora e a luz dos ensinamentos evangélicos de que são portadores. No parlatório C estavam os espíritas ao lado dos seus Irmãos livres da liga espírita do DF que falaram sobre o dia dos encarcerados, sobre o dia das mães, antes de suas habituais pregações. Na capela, celebrou-se missa solene pelo Ver. José Alberto Castro Pinto e pelo Seminarista Cândido Ribeiro Corrêa auxiliados pelo sacristão, nosso companheiro Aurélio Costa. O coro da Congregação Mariana da Penitenciária, entoando os cânticos sagrados, completou com as belas palavras do reverendo sobre o dia do Espírito Santo, o das mamães, o nosso e a intenção do culto às nossas famílias, um espetáculo que faz transbordar os corações dos que amam a Deus sobre todas as coisas, e ao próximo como a si mesmo. O nome de Deus esteve presente em todas as confraternizações - e isso é bastante para dizer que o dia iniciou da melhor forma possível (AE, maio de 1951, pp. 17 e 18).

Outra nota publicada na revista $A$ Estrela narra a visita da imagem de Nossa Senhora à Penitenciária Central do Distrito Federal. O tom devocional do texto se repete em outras narrativas do periódico, que buscam mostrar a receptividade com a qual os sentenciados lidam com a temática religiosa: 
não poderíamos deixar de incluir nas páginas do terceiro número uma passagem que ficará eterna na história da penitenciária Central do Distrito Federal: a visita de Nossa Senhora, representada pela imagem secular de Nossa Senhora do Carmo do Convento das Carmelitas do Recife (...). E foi cercada da mais intensa expectativa que chegou à pentenciária a Imagem sagrada: os corredores ficaram povoados dos fieis penitenciários que desde cedo esperavam a chegada da mãe querida dos céus após a visita dos entes queridos (AE, junho de 1951, p.45).

Encontrar Deus representaria uma forma possível de receber o perdão e por meio deste a liberdade. Não necessariamente a liberdade física de livrar-se do cárcere, mas a liberdade moral de livrar-se da culpa. Isso fica claro na conclusão da nota sobre a visita da imagem de Nossa Senhora, segundo a qual: "os fiéis puderam depois beijar a imagem da Santa entoando o 'queremos Deus' - expressão decisiva do penitenciário pela Liberdade” (p. 46). Cumprir a pena não bastava, era necessário se arrepender e ser perdoado, pois era a recuperação moral uma importante garantia contra a reincidência e o retorno ao mundo do crime. Victório Caneppa em palestra proferida na II Reunião Penitenciária Brasileira, que ocorreu no Paraná, em 1953, tratou do tema "Deus e as Prisões". Transcrita na revista A Estrela sua fala deixa clara a função que a religião deveria exercer no cárcere, em especial devido ao fato de as populações carcerárias, em geral, serem oriundas de "uma sociedade carente de melhor orientação, onde se nota graves estigmas de uma deficiência acentuada na formação de uma moral recomendável” (AE, jul/ago/set de 1953, p. 19). De acordo com Caneppa:

o homem, no fim de tudo, ao término de sua sentença, que lhe impôs a lei pelo seu erro, pode enriquecer-se de conhecimentos vários, desde a noção de fraternidade do convívio social, que se estabeleceu, pode contar com o arrimo de um ofício, e desta forma obter trabalho com facilidade, pode, não mais ser assim um vadio, um inútil, um problema grave para as nossas polícias, pode a partir dos ensinamentos que paradoxalmente grangeou na oportunidade da pena, por tudo que conseguiu obter de construtivo, até constituir 
família e dar exemplos bons, ele, o transviado de outrora. (...) Assim, a tarefa penitenciária ganha altura no desejo de reparar e a religião, lenitivo das dores recônditas do nosso mundo interior, tem que ser ministrada na docilidade da impregnação do conselho diuturno (AE, jul/ago/set de 1953, p. 19).

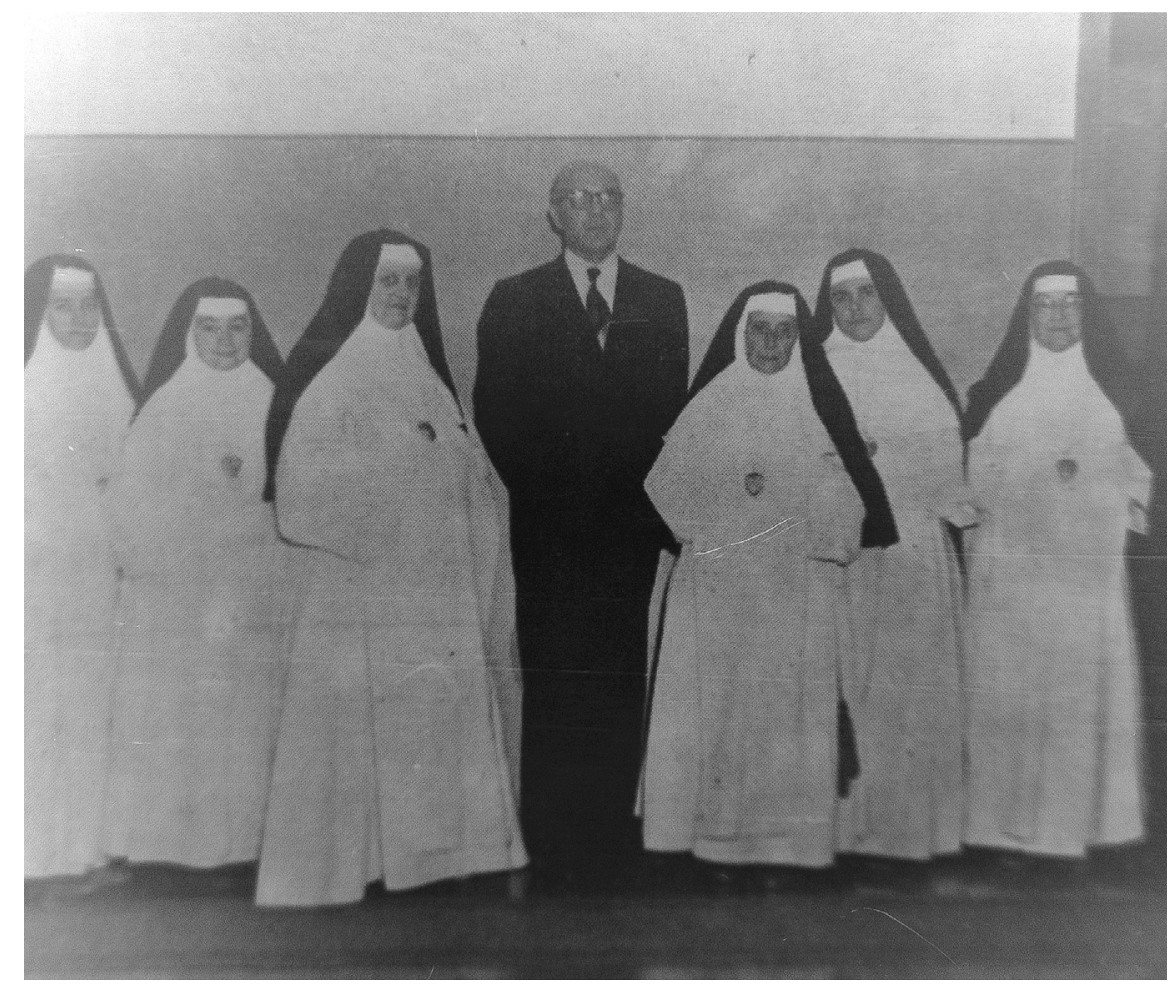

VICTÓRIO CANEPPA LADEADO PELAS IRMÃS DO BOM PASTOR D’ANGERS NA PENITENCIÁRIA DE MULHERES DE BANGU (AE, JUNHO DE 1951, S/P).

Em artigo publicado nos Arquivos Penitenciários do Brasil, denominado $O$ Código Penal Brasileiro e as Novas Teorias Criminológicas, Nelson Hungria, penalista, membro da comissão revisora do ante-projeto do novo Código Penal, critica sobremaneira o determinismo biológico do Positivismo Criminológico, e, em alguma medida as teorias psicanalíticas, que, a seu ver, retiram do homem a sua capacidade de livre pensamento e ação. Hungria se pergunta, também reportando-se a Deus:

por que havemos de aceitar a hipótese determinista, que rebaixa o homem à condição do irracional, ao invés de preferirmos a hipótese indeterminista, cuja verossimilhança é um 
dado empírico da nossa própria consciência, e que nos enobrece pela afirmação da nossa responsabilidade moral? Por que havemos de nos degradar, por hipótese, a joguete de glândulas de secreção interna, ao invés de nos afirmarmos uma consciência impregnada de Deus e voltada para Deus? Por que havemos de reduzir a nossa alma ao imaginário barato de misérias e torpezas do inconsciente freudiano, ao invés de a considerarmos um raio refracto da divindade? (APB, 1942c, p. 42).

Esta reflexão do jurista é interessante na medida em que refuta a ciência que atribui o crime a elementos orgânicos e psíquicos alterados, e reivindica a moral religiosa como elemento essencial de uma responsabilidade ética capaz de desviar os sujeitos das condutas criminosas. Tanto nas aspas de Hungria e Caneppa quanto nas notas anônimas publicadas n'A Estrela é possível perceber que o pensamento científico está aquém do pensamento mágico-religioso, mais poderoso que a Ciência, embora não a exclua. Ou seja, creditar à religião a cura moral dos aprisionados, não significa abrir mão de modelos carcerários que estão em consonância com as recomendações criminológicas do período, mas expandir as atuações sobre o preso para além do corpo material, do qual a ciência, por vezes, se ocupava. A instituição prisional poderia buscar sanear o corpo e a alma, o imanente e o transcendente, sem que isso representasse uma contradição insuperável, uma vez que as curas eram de ordens distintas, mas, na prática, uma não atrapalhava a outra. Assim, é possível afirmar que a lógica globalizante do pensamento mágico englobava o pensamento científico coexistindo com este nos estabelecimentos prisionais do período.

No caso específico dos presídios femininos, idealmente a religião deveria ser eficaz na formação de uma mulher conveniente às expectativas do Estado - controlada, catequisada e moralmente sadia. Também o desoneraria de organizar e administrar uma instituição voltada para um público com o qual não tinha experiência. Por outro lado o trabalho com mulheres presas permitiria à Igreja expandir suas missões em parceria com o Estado, conquistar novas fiéis e, no caso específico das Irmãs do Bom Pastor d'Angers, colocar em prática não só um trabalho que já realizavam em outros países, e que tinha direta ligação com sua vocação, como também prosseguir 
com a expansão da ordem que crescia vertiginosamente em todo o mundo. $\mathrm{O}$ papel da religião nos cuidados com a mulher é ressaltado por Lemos Britto, que, ao justificar a presença das religiosas nos cárceres femininos pontua a importância da educação religiosa nesses espaços.

O penitenciarista demonstra, em seu discurso, entusiasmo com a Igreja e seus métodos para a cura das delinquentes. $\mathrm{O}$ potencial feminino de crença e superstição, já apontado por autores como Lombroso, é retomado por Lemos Britto para justificar a importância da educação religiosa praticada nos cárceres para mulheres. Temer a Deus era ação capaz de transformar as prisioneiras de maneira positiva, uma vez que:

(...) a grande maioria delas ainda conserva a crença e o temor do supremo artífice do universo, tendo a religião uma influência decisiva sobre seu espírito, valendo por um freio a suas paixões e por um tônico maravilhoso para suas almas aflitas, nas quais mantem acesa a lâmpada da fé num dia mais límpido e mais feliz. De um certo modo poder-se-ia dizer que democracia é o cristianismo aplicado às relaçôes do Estado e da Sociedade (LEMOS BRITTO, 1943, p. 25) (grifo meu).

Nesse sentido, é possível concluir que a presença católica no Brasil em instituições vinculadas ao Estado é menos paradoxal do que parece, uma vez que fez parte de uma articulação política que beneficiava ambas as partes. Especificamente no caso do cárcere feminino, a presença das Irmãs facilitou sobremaneira a implantação dos presídios para mulheres no país. Naquele momento, a estruturação do cárcere e sua função eram bem mais importantes que qualquer preocupação com a laicidade: era necessário resolver a questão prática de serem criados e funcionarem devidamente os cárceres femininos. Ademais, considerando que o crime praticado por mulheres era percebido por vezes como da ordem do pecado, sendo, portanto, a transgressão traduzida como um ato pecaminoso, era na cura dessa alma pecadora que o tratamento carcerário deveria agir. Igualmente, o fato de a mulher criminosa ser tida como uma degenerada social, a quem faltava educação e ensinamentos de 
um "dever ser" mulher, o antídoto a ela prescrito era a regulação moral e a doutrinação do corpo desordenado. A prostituta, a vadia, a criminosa reincidente, e toda sorte de mulheres criminosas deveria ser levada a conter a sua sexualidade e a canalizá-la para a reprodução de uma família cristã. Quem melhor do que as freiras para ter o antídoto para esse mal moral?

\section{Missão das Irmãs e o}

\section{encarceramento feminino no Brasil}

na verdade todas as religiosas do Bom Pastor dão a vida por suas ovelhas, de um modo ou de outro. Mas às Mestras das Prisóes e dos Patronatos de Menores é que se aplica propriamente esse grau de semelhança com o Nosso Senhor. Estas, sim, dão, de fato, a vida pelas suas ovelhas, pois quase sempre arruinam a saúde nesse obscuro martírio de cada dia

Madre Batista de Oliveira ${ }^{80}$

A tendência das Irmãs do Bom Pastor d'Angers em ressaltar a dificuldade de seu ofício, de modo a mostrar o sacrifício feito em nome do Senhor para a recuperação daquelas que delas necessitavam, pode ser percebida no relato da Madre Batista de Oliveira, primeira superiora da Penitenciária de Mulheres de Bangu, acima transcrito. A doação ininterrupta ao cuidado das internas é ressaltada na maioria dos discursos, cartas e documentos produzidos pelas Irmãs. Habitando o mesmo estabelecimento que as detentas, em alas distintas, as Irmãs vivenciavam o cotidiano carcerário e se responsabilizavam por sua administração. Apesar das cláusulas que constam nos contratos que regulamentam os estabelecimentos prisionais dos estados do Rio de Janeiro e São Paulo, segundo as quais o trabalho de enfermagem deveria ser realizado pelas Irmãs, nos relatos dos penitenciaristas, nas passagens que tratam do cotidiano prisional nos cárceres femininos presentes nos

$80 \quad$ Madre BATISTA de OLIVEIRA, apud CAMPOS, 1981, p. 177. 
periódicos analisados, bem como na obra de Campos (1981), que trata da história da Congregação no país, a cura da "alma" e não do corpo aparece como função principal das Irmãs. Tanto é que em Bangu havia a previsão de que as mulheres presas na Penitenciária poderiam usar, quando necessário, o hospital do Sanatório para tuberculosos, uma vez que eram poucas as detentas, por volta de 50, o que não justificava a construção de um aparato hospitalar somente para elas. Por mais que houvesse a previsão contratual de que as Irmãs deveriam exercer tarefa de enfermagem, os cuidados físicos eram menos relevantes em sua administração do que aqueles focados na recuperação moral. Trabalho, disciplina, amor à família, saberes domésticos, arrumação na medida certa, discrição e caridade - eis o que as irmãs deveriam inculcar nas prisioneiras.

Já o trabalho com o corpo, realizado pelas Irmãs, era antes uma tentativa de disciplinarização do que propriamente de cuidado médico. Cabia "organizar" o corpo das internas de modo que estas se portassem como mulheres honestas e castas - a disciplina do corpo ligava-se à busca da ordem moral da alma. O corpo higienizado, sadio e comportado era a morada ideal para a alma moralizada. Em descrição sobre a Penitenciária de Mulheres de Bangu presente na revista A Estrela, o repórter ressalta que "o banheiro é coletivo, o que facilita às madres a fiscalização da higiene do corpo em certas horas, pela manhã e à tarde". A conferência do corpo nu com o objetivo de verificar a higiene evidencia a observação constante das Irmãs sobre as detentas e o alcance do olhar disciplinar, que penetrava espaços íntimos, como o banheiro.

Elça Mendonça Lima, em sua análise sobre as origens do sistema prisional feminino no Rio de Janeiro, continua a análise do contrato entre as Irmãs e o Distrito Federal ressaltando que às Irmãs caberia o cuidado do corpo e da alma das detentas, um cuidado médico-moral com o intuito claro de doutrinar em todos os aspectos possíveis as mulheres sob seus cuidados. Segundo a autora:

na ordem da enumeração das tarefas, 'enfermagem e assistência' aparecem como o atributo principal do serviço contratado. As outras tarefas são apresentadas como correlatas e dão a impressão de que sua explicitação corresponderia a uma simples preocupação 
de exaustividade do enunciado. Isto é, buscariam esgotar os âmbitos possíveis de obrigações da administração de um 'internato'. (...) as duas primeiras idéias, 'enfermagem e assistência', dotam o governo desse 'internato' de uma qualidade eminentemente clínica. Ora, a ênfase neste aspecto pode já estar advertindo da razão precípua porque se contratou a Congregação, qual seja, a de que as freiras são especialistas do cuidado do corpo e da alma. De um cuidado com a alma que implica certa relação de disciplina e vigor com o corpo (LIMA, 1983, p. 55).

A acertada análise da pesquisadora coincide com os relatos dos trabalhos das Irmãs nos estabelecimentos prisionais femininos, nos quais deveriam cumprir o papel de enfermeiras de corpos e almas. Por exemplo, o Guia das Internas do Presídio de Mulheres da Penitenciára de Mulheres de Bangu retrata com clareza esta missão. Suas páginas traduzem a função esperada do aprisionamento feminino e seus efeitos sobre as presas. $\mathrm{O}$ resultado que as detentas deveriam alcançar era o de "adquirir as qualidades indispensáveis para ser feliz e portadora da felicidade”, o que era obtido por meio de orações, disciplina, "vivência digna do tempo", dedicação ao trabalho, ordem e asseio, aprendizado de uma moral cristã, respeito para com as autoridades, subserviência em relação à Deus, discrição e serenidade.

Logo na primeira página, a introdução ao Guia frisa a importância da ordem para o bom funcionamento da instituição, ressaltando que:

a ordem é um princípio de felicidade e paz. O coração fica satisfeito, quando, dominando o capricho e cumprindo o dever, pode verificar que nobremente cumpriu a sua missão. A ordem é ainda um princípio de progresso, pelo ambiente benfazejo que ela estabelece - Olhai para a nossa Bandeira, e nela encontrareis um lema, que é todo um programa de vida: - ORDEM E PROGRESSO (RIO DE JANEIRO, 1983, p. 79).

A ordem deveria estar presente no espaço e no tempo - não apenas o estabelecimento deveria ser organizado fisicamente, como também era fundamental a organização do tempo prisional, de modo a distribuir cronologicamente um coti- 
diano de disciplinas. O tempo da presidiária na Penitenciária de Mulheres de Bangu era assim distribuído:

$1^{\circ}$ - Erguer-me imediatamente ao sinal de despertar, com um pensamento bom, com uma saudação a Deus.

$2^{\circ}$ - Fazer a minha "toilete", arranjar-me com capricho. Arranjar minha célula.

$3^{\circ}$ - Cada dia, assistência facultativa à Santa Missa.

$4^{\circ}$ - Café.

$5^{\circ}$ - De 8 às 11 horas, ocupar-me do trabalho que me foi assinalado.

$6^{\circ}$ - Às 11 horas instrução de cultura moral.

$7^{\circ}$ - Meu almoço, seguido de recreio.

$8^{\circ}$ - A 1 hora voltar ao meu trabalho, estudos etc.

$9^{\circ}$ - Às 2,30 horas - lanche.

$10^{\circ}$ - Às 4 horas - banho.

$11^{\circ}$ - Às 5 horas - Reunião de Moral - Terço rezado em comum.

$12^{\circ}$ - Às 5,30 horas - jantar seguido de recreio.

$13^{\circ}$ - Às 7,30 horas - Oração da noite - Recolhimento à célula. (RIO DE JANEIRO, 1983, p. 80)

Os compromissos religiosos estavam presentes desde o despertar - quando Deus deveria ocupar o pensamento das detentas - ao horário do recolhimento noturno - que era precedido por uma oração. O Guia das Internas previa que a religiáo deveria ocupar o dia de modo a permitir que elas encontrassem caminhos de acertos capazes de desviá-las dos rumos seguidos anteriormente. Por meio da doação à religião a mulher encarcerada seria capaz de "chegar à verdadeira felicidade" e compreender o "sentido da vida".

$\mathrm{Na}$ revista $A$ Estrela, em reportagem sobre a Penitenciária de Mulheres de Bangu, há dois trechos de entrevistas - realizadas com uma detenta, que inclusive é a colaboradora da revista, e uma ex detenta - que merecem destaque, justamente por passarem a impressão de que o "sentido da vida" foi e seria ali encontrado, tanto 
por ser uma "escola de bem" quanto pelos resultados já obtidos com a ex-reclusa. As aspas que compõem a reportagem ressaltam justamente o que o repórter quer mostrar - um local santo e familiar:

aproximamo-nos de Dona Dinorah, uma senhora de olhos grandes, reveladores de certa argúcia e vasto conhecimento de vida. - Qual a sua impressão? Ótima! Estou aqui há pouco tempo, mas já tenho conscienciosa impressão do ambiente; não é uma penitenciária - é uma escola do bem. Aqui nada falta para tornar menos sofrida a nossa existência de reclusas.

depois entrevistamos uma mocinha recém-saída do presídio. Disse-nos ela emocionada: Vim hoje aqui espontaneamente trazer o meu testemunho de gratidão às freiras. Fui posta em liberdade há dias, mas nunca esquecerei os benefícios espirituais que auferi da convivência das Irmãs. Vim hoje aqui, repito, não só para testemunhar isso, mas para mais uma vez, aproximar-me dessas santas criaturas. Elas fazem tudo para reerguer o seu semelhante prostrado pela vida. - Os olhos da jovem que diz essas palavras estão humidecidos de lágrimas. Vê-se que é profundamente sincera (AE, set/out de 1951, p. 62).

O compromisso de instrução de cultura moral, sexto item do cronograma do Guia, deveria ser cumprido na sala de moral da penitenciária, onde as instruções deveriam se dar no sentido de "aprofundar as lições aprendidas no catecismo", investir na "correção dos defeitos" de cada uma, no aprendizado de "economia doméstica", "higiene" e educação de todas as "potências do corpo e da alma”. De acordo com o próprio Guia, "o que uma sala de reunião familiar é para um lar, a sala de moral deve ser para as internas”, ou seja, um espaço de diálogo, educação e aprendizado de elementos típicos do papel social que cabia a cada uma no seio da família. Em visita à Penitenciária de Mulheres de Bangu, o repórter da revista $A$ Estrela ressalta a função das aulas de instrução moral, que ocorriam na "sala de moral" que, de acordo com o visitante: 
tem boas dimensões e uma instalação que convida à meditação. Ali, diariamente, das 11 às 11:30, são reunidas todas as habitantes da Casa; elas ouvem conselhos, recomendações e palavras que lhes invadem os corações como a mensagem materna, que a muitas, certamente faltou (AE, junho de 1951, p. 5).

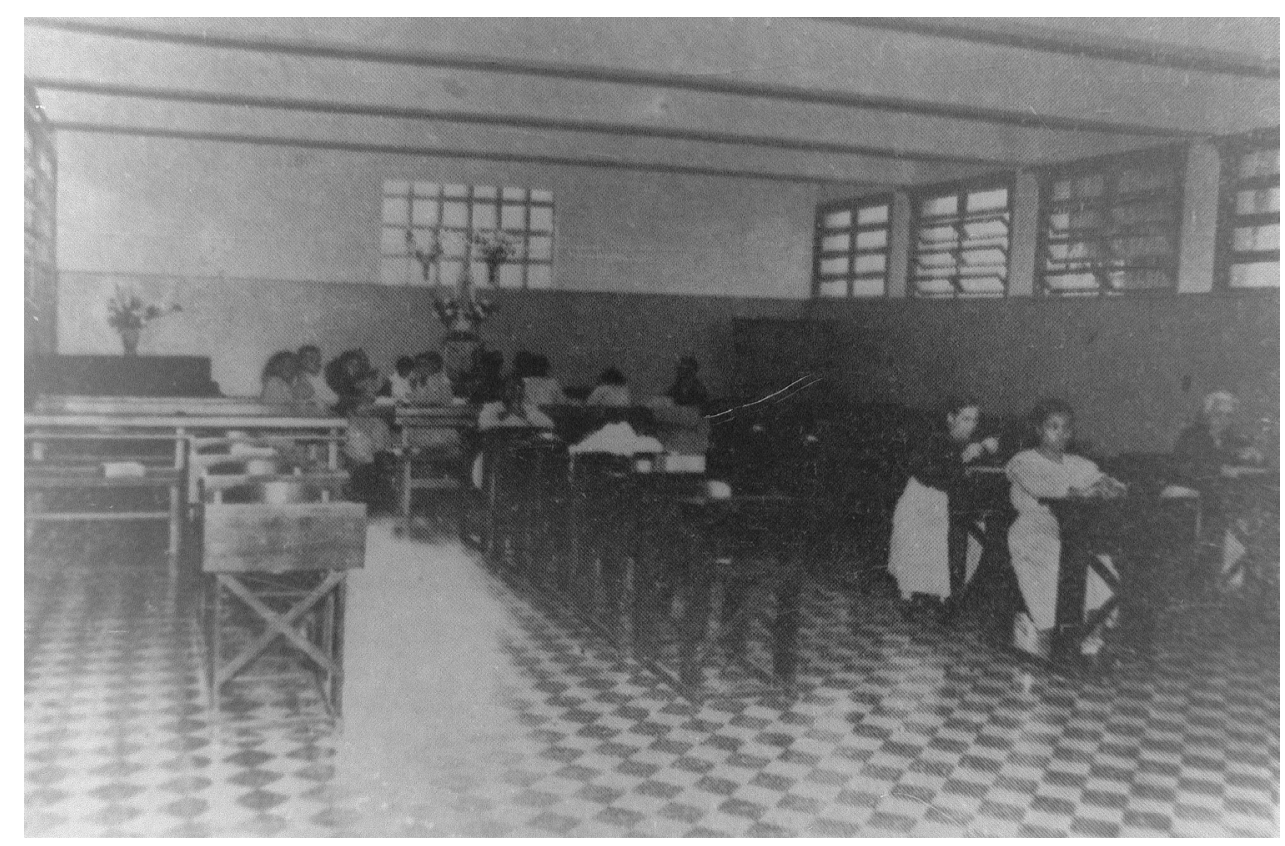

SALA DE MORAL DA PENITENCIÁRIA DE MULHERES DE BANGU (AE, JUNHO DE 1951, S/P).

A maioria das mulheres que compunha o universo carcerário feminino era vista como pouco instruída nas lições que deveria aprender uma representante digna e honesta do sexo feminino, sendo fundamentais as aulas de instrução de cultura moral para o aprendizado da cartilha de um "dever ser" da mulher cristã. No Ante-Projeto de Regimento da Penitenciária de Mulheres de Bangu, proposto pelo Conselho Penitenciário, a educação moral deveria estar voltada para "sempre despertar-lhes [às mulheres] o amor da família e a compreensão de seus deveres para com a sociedade" (APB, 1942d, p.49). A resposta de uma Irmã ao repórter de $A$ Estrela que pergunta sobre os objetivos das aulas de moral aponta as rédeas morais que se buscava colocar nas detentas:

(...) nosso maior desejo é que se convençam de que não é a disciplina metrificada da prisão o que nos interessa - preferimos que sintam a necessidade de disciplinarem o espíri- 
to, mas gozando de liberdade, praticando o bem quando lhes seja possível praticar o mal, por conviç̧ão tão simplesmente (AE, junho de 1951, p.5).

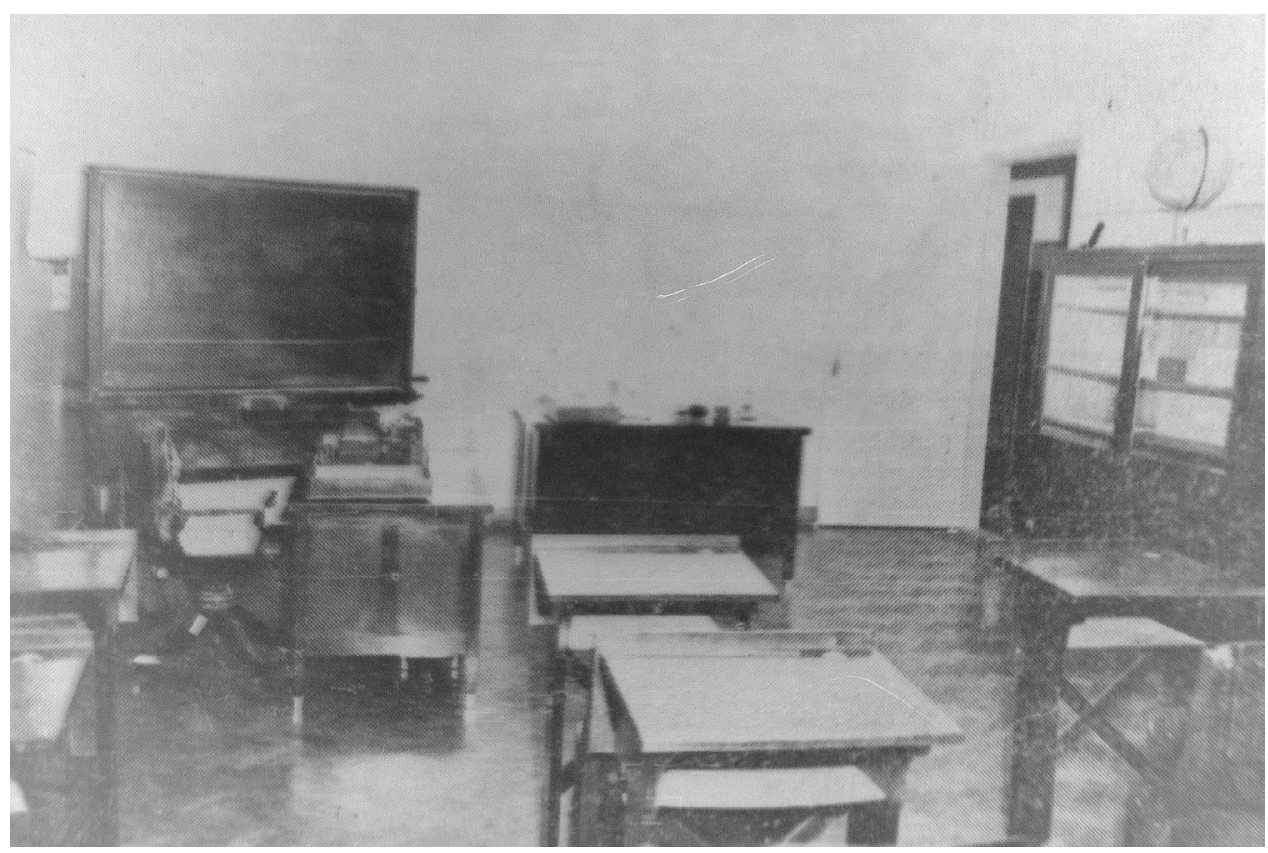

SALA DE AULA DA PENITENCIÁRIA DE MULHERES DE BANGU (AE, JUNHO DE 1951, S/P).

Já ao falar dos resultados do trabalho de recomposição moral das internas, a Irmã deixava claro que se pretendia "docilizar" ${ }^{81}$ essas mulheres, que deveriam abandonar posturas agressivas e intolerantes e adquirir um temperamento próprio para uma mulher/mãe/esposa/cuidadora. Em suas palavras:

não somos otimistas a ponto de declará-los inteiramente satisfatórios, entretanto sempre se colhe alguma coisa que reflete o nosso trabalho; a influência é um fato, modifica-as a idéia, tornando-lhes calmas, pacientes. É um trabalho um tanto moroso, como disse, dosado, porém eficiente para o objetivo que visamos - o soerguimento moral" (AE, junho de 1951, p. 6)

81 Expressão utilizada por Michel Foucault em Vigiar e Punir - história da violência nas prisôes, que significa tornar dócil, amansar, domesticar, domar. 
O Guia das Internas prescrevia, também, de que maneira as internas deveriam se relacionar com as autoridades: com respeito, sem alarde, cumprimentá-las sempre, com "certa distância" corporal e "com uma inclinação respeitosa". As detentas não poderiam discutir política nacional, criticar as "Leis do País", os "Poderes Públicos", a "Religião" e a "Diretoria do Estabelecimento". O controle sobre o corpo pode igualmente ser percebido nas regras de como as internas deveriam se comportar no refeitório. Há descrições detalhadas do que podia e não devia ser feito - do tom de voz moderado com o qual poderiam conversar durante a refeição, à maneira "distinta" que deveriam se sentar, buscava-se regulamentar todas as ações:

é falta de educação pegar os alimentos com as mãos, mastigar com a boca aberta, dar estalidos ao ingerir alimentos líquidos, deitar-se nas mesas, apoiar sobre elas os cotovelos, falar de coisas repugnantes, ter atitudes grosseiras, portar-se como animais que devoram tudo com demasiada avidez (RIO DE JANEIRO, 1983, p. 85).

A limpeza, a ordem, o asseio, eram elementos essenciais que deveriam ser praticados rigorosamente no interior da Penitenciária, não somente por serem necessários em um ambiente de convívio coletivo, mas também por serem qualidades que deveriam acompanhar a mulher e sua relação com o mundo, como ressaltava o próprio Guia, segundo o qual "se a ordem é necessária em toda a parte, quanto mais é indispensável em tudo o que rodeia a existência da mulher". Ao mesmo tempo em que esse cuidado asséptico deveria ser exercido no espaço físico da penitenciária, deveria ter consequências internas nas detentas, que passavam por um período de "faxina moral". A limpeza do ambiente e do corpo refletia a candura da alma. Ao relatar sua visita ao Instituto Feminino de Readaptação Social de Porto Alegre, Victório Caneppa deixa transparecer a centralidade da limpeza "externa" e "interna", e a relação entre higiene, purificação e felicidade. Em suas palavras:

as recolhidas ao reformatório estão bem instaladas num grande prédio - à Avenida Getúlio Vargas -, cujas instalações, não sendo luxuosas são higiênicas. Vi uma por uma des- 
sas criaturas em número de 30, e percorri os dormitórios, a sala de costura, a copa, a cozinha, e de tudo o que me foi dado ver tive a melhor das impressões. Não só a ordem e a limpeza impressionam, mas também, e, sobretudo, a maneira pela qual são essas infelizes tratadas pelas Irmãs do Bom Pastor, que se dedicam dia e noite ao bem estar dessas criminosas, depurando-lhes o coração, purificando-lhes a alma, reabilitando-as perante a Deus e os homens (APB, 1941a, pp. 257 e 258).

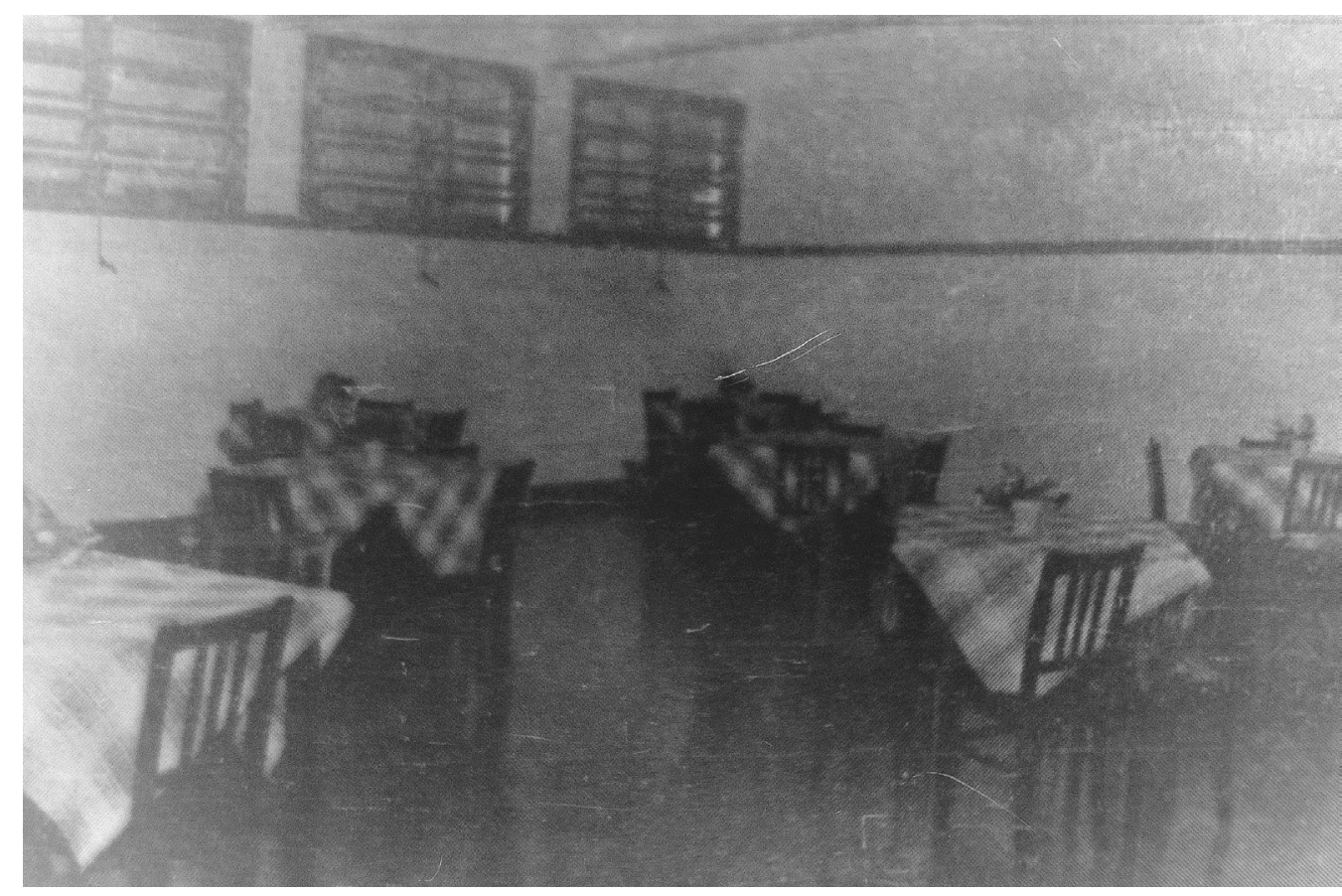

REFEITÓRIO DA PENITENCIÁRIA DE MULHERES DE BANGU (AE, JUNHO DE 1951, S/P).

Se ordem e limpeza eram tidas como essenciais à mulher, para que fossem realmente felizes estas deveriam ser asseadas e conviver em ambientes limpos e higienizados. Lemos Britto, em palestra denominada Evolução do Sistema Penitenciário Brasileiro nos últimos 25 anos, proferida a pedido do Instituto da Ordem dos Advogados de São Paulo, evidencia esta associação ao ressaltar que:

na penitenciária de mulheres [de Bangu] o regime é também o de refeitório, reunindo-se as reclusas por grupos de quatro, devidamente classificadas em pequenas mesas com suas toalhas bem limpas, onde elas se sentem felizes em suas vidas de prisioneiras" (APB, 1946, p.42) 
No item do Guia denominado "das modas e modos", que trata da aparência das detentas, dos cuidados com o uniforme e da maneira como estas devem se apresentar, há uma evidente preocupação em equilibrar dois extremos da arrumação: o desleixo e a vaidade. Segundo o Guia, "na negligência há um fundo de preguiça, uma falta de senso e de gosto. Também é preciso evitar a excessiva preocupação com a 'toillete', que denota espírito leviano e falta de valor pessoal'. O estereótipo negativo da futilidade feminina, da preocupação exacerbada com a aparência, tão presente no imaginário popular, em especial a partir da maior circulação feminina nos ambientes urbanos, e amplamente explorado pelos comerciantes do consumo, contrastava com um desenho, igualmente negativo, de mulher desleixada e relaxada, que não se arrumava e não se preocupava em apresentar-se de uma "maneira feminina". O comedimento, a regulação dos destemperos, a medida exata das manifestações as Irmãs buscavam um equilíbrio exato, o qual não permitia excessos e desvios. De acordo com o Guia cabia à mulher presa "arranjar-se com capricho, estar sempre em estado de apresentar-se convenientemente, limpa, bem penteada, graciosa, gentil em seu porte e maneiras (...)", atitudes que compunha "uma arte que toda mulher deveria especializar-se".

O imaginário da futilidade feminina, causada pelo excesso de vaidade, estava presente nas cidades em crescimento do mundo ocidental. Ao mesmo tempo em que a frivolidade era tratada como característica natural feminina era necessário combater os seus excessos, que poderiam levar a uma leviandade exacerbada. A vinculação entre futilidade e furto, feita por Lombroso em La Donna Delinquente, la Prostituta e la Donna Normale estava em consonância com esse imaginário sobre o feminino, que vinha tomando espaço nas grandes cidades na medida em que a mulher ocupava o espaço público. Exposta aos desejos do consumo, e sem meios para realizá-los, a mulher investia na criminalidade ocasional como forma de conseguir os objetos, as roupas, os perfumes e acessórios que queria. Sendo assim, a educação prisional feminina devia combater esses perigosos exageros do feminino, inculcando nas mulheres um cuidado comedido consigo. 


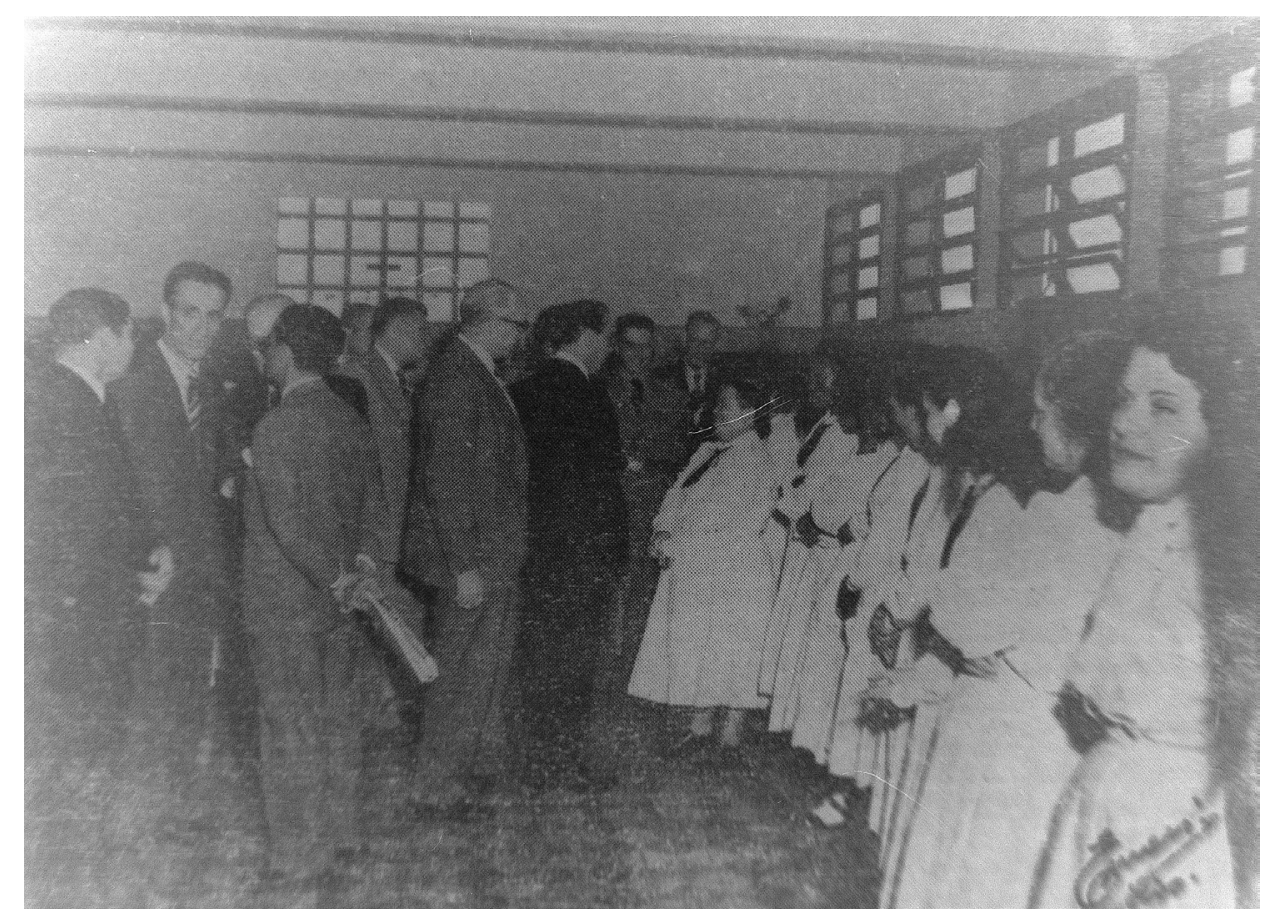

DETENTAS CUMPRIMENTANDO AS AUTORIDADES EM DIA DE FESTA

NA PENITENCIARIA DE MULHERES DE BANGU (AE, JUNHO DE 1951, P. 14).

Nesse sentido, os uniformes das detentas nas penitenciárias femininas deveriam conter elementos de feminilidade, sem tender para a frivolidade. Vestidos longos e largos que não evidenciavam as curvas femininas e que ao mesmo tempo denotavam ordem e limpeza foram adotados nos estabelecimentos como vestimenta padrão das internas. Ao final de uma apresentação artística que ocorreu, em 1951, na Penitenciária de Mulheres de Bangu, no dia da inauguração de novos pavilhões, na presença de autoridades políticas e penitenciárias, o repórter da revista $A$ Estrela traduzia a imagem que o uniforme transmitia, ao ressaltar que "retiram-se as detentas para o pátio de recreio, como uma revoada de pombos, tal a impressão que retivemos do seu gracioso uniforme branco" (AE, set/out de 1951, p. 60). Ressaltou, assim, a imagem que o uniforme transmitia. Pureza, feminilidade comedida, candura, alvura e inocência eram estampadas nos corpos das presas por meio de seus uniformes. Ao mesmo tempo, na Penitenciária de Bangu, por exemplo, era proibido o uso, pelas internas, de acessórios e jóias, elementos que traziam frivolidade ao visual modesto e comedido que deveriam apresentar. 
O estímulo à feminilidade das detentas e ao mesmo tempo a contenção de sua manifestação exacerbada era um desafio colocado pelas Irmãs. Nesse sentido o artigo de Pires de Abrahão, advogado gaúcho, publicado no jornal $A$ Nação da cidade de Porto Alegre, e reproduzido nas páginas dos Arquivos em 1941, que detalha o funcionamento do presídio de mulheres Maria Nostra, na Hungria, e o compara ao Instituto Feminino de Readaptação Social , construído na capital do Rio Grande do Sul, evidencia o equilíbrio que deveria ser alcançado em relação ao "elemento feminino". O autor pontua que na penitenciária húngara predominava o trabalho, a religião e a simplicidade, estando as mulheres sob a administração de Irmãs católicas. De acordo com Abrahão, o segredo para o bom funcionamento da casa estava no investimento das Irmãs em um espaço onde predominava "o elemento feminino", estando os homens proibidos de frequentarem e trabalharem no recinto. A presença exclusivamente feminina deveria operar no sentido de anular alguns componentes atribuídos à feminilidade, já que, para o autor, a simplicidade e austeridade exigidas pelas Irmãs eram fundamentais para dispersar as futilidades femininas que tanto mal provocavam à sociedade. Segundo Abrahão,

nos domínios do Maria Nostra todas são iguais. Usam toucas nos cabelos, blusas de algodão, uniformizadas e trajam, quanto ao mais, com rigorosa simplicidade, em nada obedientes aos imperativos e aos luxos da moda feminina que levam muitos lares à miséria (APB, 1941b, p. 345).

As detentas também deveriam ser comedidas na manifestação de suas alegrias durante os recreios e em outras ocasiões sociais na penitenciária. Falar baixo, devagar, sem exageros emocionais. O Guia, ao tratar do comportamento das internas durante os momentos de recreação ressaltava que "os recreios devem ser animados, alegres, mas de uma animação discreta e educada". Gritos, vaias, assobios, "gargalhadas espalhafatosas", "cantos indecorosos", "cantos e danças de macumba" - todas essas manifestações eram proibidas e/ou deveriam ser evitadas. Em suas relações com as companheiras de cárcere, as internas deveriam, igualmente, manter a discrição, 
cultivar a gentileza, a caridade e a compaixão. Sem difamações, xingamentos, gestos bruscos, violências - eis como deveriam se relacionar umas com as outras.

Todos esses elementos de disciplinarização praticados pelas Irmãs sobre os corpos e mentes das detentas coincidiam com aqueles aos quais elas deveriam submeter-se em suas vidas de religiosas. Em outras palavras, a vida monástica exigia das Irmãs a aniquilação da sexualidade, o recato e a discrição nos modos, o uso de uniformes, uma rígida rotina de orações e trabalhos, o abandono de uma feminilidade exacerbada, enfim, a vivência de uma vida modesta e sem futilidades, dedicada a Deus e à caridade. Os rigores do ordenamento religioso coincidiam com os rigores da disciplina carcerária.

Vale ressaltar, ainda, que nos documentos pesquisados não há menção a castigos e medidas correcionais aplicadas nas instituições. A palavra "castigo" aparece na maioria das vezes associada a práticas prisionais superadas, nunca em relação ao período analisado. Isso porque havia uma preocupação, como já dito, em mostrar o cárcere moderno como espaço "civilizado", que investia na educação e socialização das detentas e detentos. Em reportagem de A Estrela o repórter evidencia essa escolha:

em todo período de readaptação, notadamente na idade adulta, é difícil aceitar-se as reformas mentais; é evidente que as reações são muitas, e as vezes, rebeldes, insuportáveis quase. Mas o remédio não é um castigo, um mal trato - se assim compreendemos aquilo que modernamente se oferece em represália ao faltoso. Os pensadores hodiernos da matéria penitenciária admitem a situação de reflexão forçada; isto é menos que castigo e mais que reflexão. O estado psicológico deve repousar até encontrar serenidade capaz de suportar o meio e não antipatizar-se com ele (AE, junho de 1951, p. 9).

A imagem que se pretendia passar do aprisionamento no período não comportava menções a punições para além da pena. Um exemplo da ausência de referências aos castigos é o próprio Guia das Detentas que, ao tratar de comportamento cita a atribuição de "estrelas" para "classificação e desclassificação" da conduta das internas: I) estrela branca para aquelas como comportamento neutro 
- nem exemplar, nem reprovável; II) estrela amarela para aquelas de bom comportamento; e III) estrela verde para as de comportamento ótimo. Sobre o mau comportamento, há, na última página do Guia, a seguinte menção: “a interna classificada no MAU comportamento, somente terá reclassificação após seis meses de trabalho honesto e boa disciplina”. No entanto não há qualquer referência à retaliação disciplinar além do prazo para a reclassificação. Elça Mendonça Lima menciona, em sua pesquisa, que as celas para castigo, denominadas "surdas" foram instauradas em uma reforma ocorrida alguns anos depois da inauguração do Complexo de Bangu (LIMA, 1983, p. 59). ${ }^{82}$

A afirmação de Lemos Britto, feita em relatório sobre o plano de reformas do sistema penitenciário baiano, de que "mais do que as altas muralhas, e as punições disciplinares, conserva pacíficos e submissos os sentenciados um bom regime inteligentemente aplicado por funcionários instruídos e humanos" confirma a tendência de um discurso que valorizava o investimento em humanização penitenciária, e não em castigos, e que escamoteava práticas institucionais voltadas a corrigir os "maus comportamentos" (APB, 1942a, pp. 109 a 111).

Por fim, vale mencionar a saída precoce das Irmãs do Bom Pastor d'Angers da Penitenciária de Mulheres de Bangu, em 1955, que evidencia tensões pouco enunciadas nos documentos pesquisados, e perpassa a questão disciplinar pouco debatida. A Irmã Margarida de Moraes Campos, ao tratar do histórico da Congregação no Brasil, refere-se ao conflito existente entre as Irmãs e a direção da $P e-$ nitenciária Central do Distrito Federal, materializado na figura de seu diretor, Victório Caneppa. Apesar dos poucos registros de conflitos com a diretoria, fato que segundo Campos se deveu à opção da Madre Superiora Batista de Oliveira de não

82 De fato, como poderá ser verificado adiante, na planta da Penitenciária de Bangu não havia a previsão de espaços de castigo. Em 1953 foram construídas, em Bangu, dez surdas (ILGENFRITZ e SOARES, 2002, p. 60; LIMA, 1983, p. 66) 
expor a tensão vivida, é possível verificar que em Bangu a saída das Irmãs não se deu de maneira tranqüila.

Nos raros relatos de mal estar entre a diretoria e a Congregação, fica claro que o principal “inimigo" das Irmãs era, de fato, Victório Caneppa, pois, nos anos do governo Dutra, no qual Caneppa foi destituído do cargo de diretor, quando a penitenciária Central do Distrito Federal fora dirigida pelo Tenente Castro Pinto, as satisfações com os trabalhos realizados predominam nos relatos da Congregação. É desse período, por exemplo, a afirmação da Madre Provincial Affonso Penna, segundo a qual "as prisioneiras, cujo número varia entre 50 e 70 , têm tido o benefício de alguns retiros pregados com resultados bem consoladores. Muitas regularizam suas vidas. Elas e os filhos recebem o batismo e aproveitam bastante a estada entre nós" (Madre AFFONSO PENNA, apud CAMPOS, 1981 p 179).

Com o retorno de Caneppa, as tensões voltaram, em especial pelo fato de terem sido destinadas à Penitenciária de Bangu as mulheres detidas por vadiagem na cidade do Rio de Janeiro, o que ampliou, sobremaneira, o número de internas do estabelecimento. Em carta escrita pela Madre Provincial Affonso Penna à Caneppa, a Irmã deixa clara a insatisfação da Congregação com o episódio. Em suas palavras:

(...) venho expor-lhe as dificuldades com que lutam nossas Irmãs da Penitenciária, problemas que exigem uma solução. Como o Sr. sabe, o trabalho naquele setor é muito árduo, mas ultimamente tem se tornado penosissímo. Julgávamos que com o aumento dos dois pavilhões novos, muitas lacunas seriam preenchidas. Podendo cada presa ocupar sua cela individual, o que tornaria possível a vigilância. Como é de seu conhecimento, o número de presas tem ultrapassado muitíssimo o que a casa comporta. Essas pobres mulheres são alojadas em salas na maior promiscuidade (...). Nossas Irmãs, com sacrifícios heróicos, não conseguem dominar a situação. Um grande número de detidas permanece três, quatro dias na Casa, prejudicando horrivelmente a disciplina, sem que se possa ocupá-las em qualquer trabalho. (...) Desejava saber claramente se vão tomar em consideração esta nossa carta, para que eu possa tomar minhas providências, pois, com grande pe- 
sar, caso contrário, não nos poderemos encarregar mais dessa Obra (Madre AFFONSO PENNA, apud CAMPOS, 1981, p. 179).

O tom da carta escrita pela Madre deixa clara a tensão presente. O debate evidencia que o diretor acusava as Irmãs de "omissão, quando a circunstância exigia da parte delas energia e força moral" e, apoiado em supostos relatos de presas, alegava a ocorrência de maus tratos (CAMPOS, 1981, p. 179). Já as Irmãs se defendiam, ressaltando a extrema dedicação da Congregação à Penitenciária de Bangu, que recebera das Irmãs o apelido de "coroa de espinhos da província". Outra carta escrita pela Madre Affonso Penna, em 1953, em retaliação à entrevista veiculada na rádio sobre a Penitenciária de Mulheres, evidencia a animosidade entre as administradoras e a direção Central. De acordo com a Madre:

(...) já estando decidida a retirada das Irmãs da Penitenciária de Mulheres, não acho necessário mais discutir sobre o assunto. Entretanto não posso deixar de pedir ao Sr. Diretor que me informe quais são as tremendas queixas, feitas pelas detentas, com relação às Irmãs (...). Quanto aos maus tratos, o Sr. é testemunha de que o Sr. Mostradeiro, enquanto administrador do Sanatório Penal, queixou-se da extrema benignidade das Irmãs para com as prisioneiras, alegando que isto prejudicava a disciplina (Madre AFFONSO PENNA, apud CAMPOS, 1981, p. 180).

Em 1954, a então Provincial Madre Matilde do SS Sacramento Batista de Oliveira, escreve carta ao novo diretor da Penitenciária Central do Distrito Federal, Hélio Tornaghi, na qual relata os motivos da saída das Irmãs. Dentre eles, ressalta as graves infrações disciplinares das internas que geravam dificuldades, por parte das Irmãs, de atingirem a "consecução de sua finalidade profissional" (CAMPOS, 1981, p. 182). Já um relatório geral dos anos de 1951 e 1952 da Penitenciária Central do Distrito Federal, redigido por Caneppa, ressalta, que a Penitenciária de Mulheres 
foi a única seção deste Estabelecimento que não correspondeu às nossas aspirações. Como é notório a Penitenciária de Mulheres é administrada pelas Irmãs do Bom Pastor, que nem sempre podem exercer cabalmente aquelas funções, como por exemplo acontece quando as coisas tomam proporções diferentes da rotina que estão acostumadas, como ocorreu nesse ano, quando prendeu e apresentou à Penitenciária mais de 1100 mulheres e o movimento de apresentação subiu a mais de 2200 , de forma que houve alguma irregularidade nesta Seção, originada pela falta de energia, disciplina e sobretudo do conhecimento das questões penitenciárias e administrativas dessas abnegadas Irmãs. Foi necessário colocar à frente daquele estabelecimento um funcionário categorizado, de comprovadas habilidades para imprimir nova orientação e disciplina às internas que na sua maioria são mulheres vadias e decaídas moralmente (CANEPPA, apud ILGENFRITZ E SOARES, 2002, p 62).

Caneppa, ao propor a presença de um “interventor” na administração das Irmãs, acirrou uma celeuma política que não foi solucionada. Os argumentos de superlotação e dificuldade de desenvolvimento do trabalho disciplinar das Irmãs são reiterados no discurso do Diretor da Penitenciária Central do Distrito Federal. No entanto, os documentos pesquisados não apontam os meandros políticos existentes, não sendo possível saber até que ponto tal situação insustentável não foi gerada de modo a acelerar o processo de saída das Irmãs e o que das denúncias contra as Irmãs de fato havia acontecido. Mas, o que mais importa ao presente trabalho é apontar como os diferentes atores se posicionam e se colocam no debate, confrontando representações e práticas. É interessante, nesse sentido notar, como as Irmãs, nos textos escritos pelos penitenciaristas, aparecem sempre como criaturas passivas, ao passo que nos livros sobre a Congregação e nos registros das Irmãs, elas aparecem como sujeitos ativos - formas selecionadas de colocar-se e ser colocado. As disputas entre a Congregação e o Estado eram, principalmente, de ordem política, envolvendo diferentes interesses nos espaços de poder e controle dos estabelecimentos prisionais.

Nas penitenciárias femininas das cidades de São Paulo e de Porto Alegre as Irmãs permaneceram respectivamente até 1977 e 1981. No Estado de São Paulo, in- 
clusive, na cidade de Tremembé, uma nova penitenciária feminina foi construída em 1962, tendo ficado sob a administração das Irmãs até o ano de 1980 (Campos, 1981, p. 271 ${ }^{83}$. As razões alegadas por elas para o fim do contrato entre a Congregação e o Estado foram, segundo Campos, semelhantes para os três estabelecimentos, sendo os motivos declarados pela Irmã M. Benigna para a saída de São Paulo, exemplares da situação como um todo:

As Irmãs se consomem nos trabalhos administrativos, disciplinares e de vigilância, obedecendo a disposições de decretos e leis penitenciárias e de administração pública; Apesar de exercerem a administração, as Irmãs não podem influir na seleção de funcionários. Pessoas despreparadas para uma missão tão específica criam entraves para o trabalho; A fim de atenderem às crescentes exigências do trabalho as Irmãs (quase todas elas) estudam. Ficam, assim, mais sobrecarregadas, sem o necessário tempo para a oração, encontros comunitários e repousos noturnos tão importantes para se refazerem dos desgastes do dia;

Não há eficácia no trabalho de evangelização. Há uma inversão de valores na aplicação das forças daquele grupo de Irmãs. Em conseqüência das circunstâncias, elas se tornam 'escravas do trabalho';

O grupo de Irmãs é por demais reduzido, enquanto que o número de presas e funcionárias aumentou. A Província está impossibilitada de encaminhar outras Irmãs para esse tipo de trabalho (Irmã BENIGNA, Apud CAMPOS, 1981, p. 244).

A missão das Irmãs de cuidar das detentas, que eram consideradas antes mulheres degeneradas que violentas, foi idealizada como solução para a implementação dos cárceres femininos no país. Dos planos e objetivos das Irmãs e dos idealizadores desses estabelecimentos à realidade cotidiana carcerária, muitas foram as adequações e os obstáculos encontrados, sendo as disputas políticas entre a Congregação e o Governo motivo de tensões ao longo dos primeiros anos dos estabelecimentos prisionais

83 No Nordeste a Congregação também ficou responsável pela administração de presídios femininos. 
para mulheres. Durante o período da administração da Congregação, a alegada valorização do potencial feminino de superação de condições de degradação moral, por meio do estímulo religioso capaz de gerar sentimentos de cuidado e amor para com a família, foi ressaltado como sendo o principal objetivo das Irmãs, que deveria se concretizar pelo investimento no trabalho, na educação e nos ensinamentos morais.

\section{DESÍGNIO E COTIDIANO - ELEMENTOS DO APRISIONAMENTO FEMININO NOS PRIMEIROS TEMPOS}

\section{Trabalho prisional feminino}

Nas horas de trabalho, de lida a mais insana,

Pensar nos entes caros, familia, lar querido.

Viver sem trabalhar é vida desumana,

É morte antecipada, torpor, tempo perdido.

Buscar a nossa força em Deus onipotente,

Fixar o olhar sereno na divinal beleza.

Cantar, sempre cantar, cantar alegremente,

Vencer, com alegria, a ingrata natureza.

Rezar para vencer, nas horas de combate,

Depois com ousadia buscar a plena luz.

Seguir novo caminho, com fé e sem debate,

Ouvir a voz de Deus, a voz que ao céu conduz.

Hino da Penitenciária de Mulheres de Bangu - Letra e Música da Madre Maria do Coração Agonizante de Jesus AE, junho de 1951, s/p. 


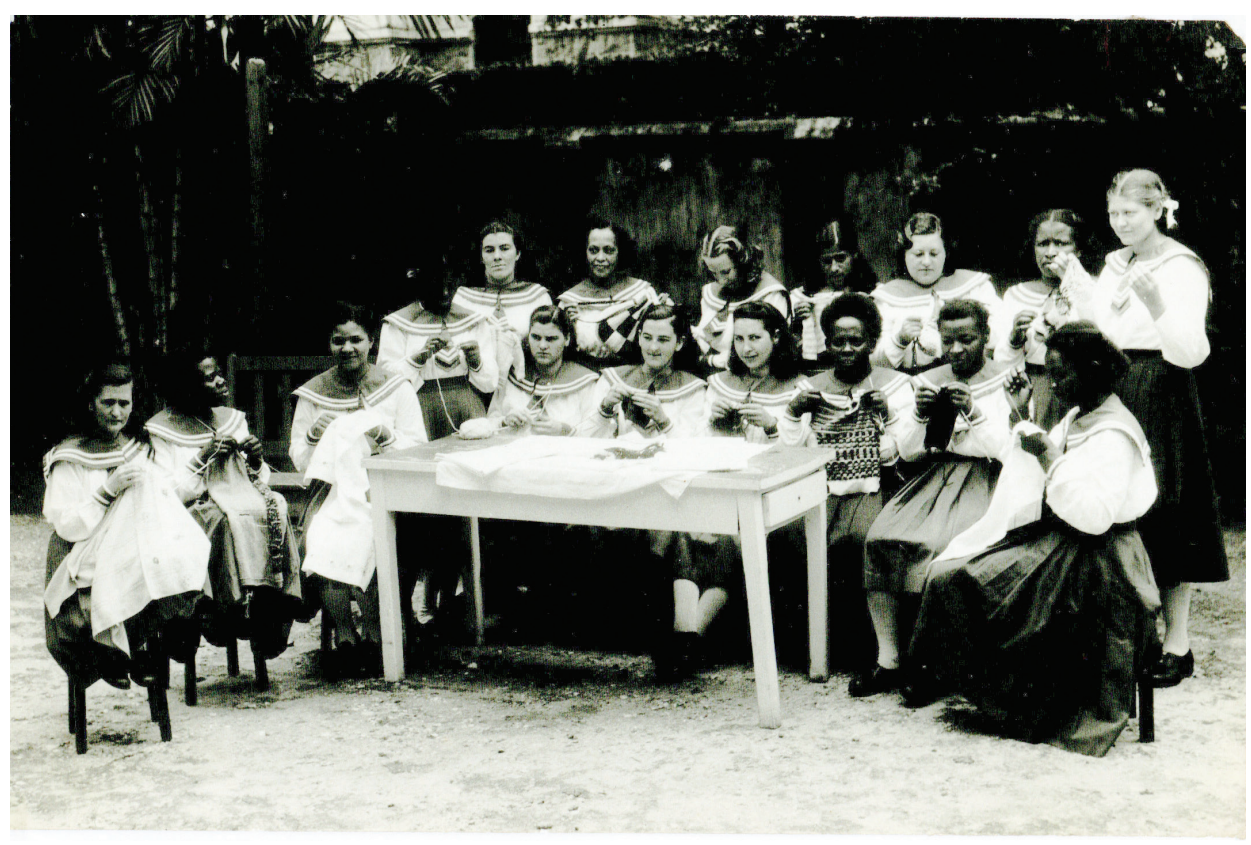

INTERNAS BORDANDO NO PRESÍDIO DE MULHERES DE SÃO PAULO - A INTENÇÃO DE MOSTRAR QUE TODAS ESTAVAM TRABALHANDO EM SEUS BORDADOS, PORTANTO, OCUPADAS E “FELIZES” É NÍTIDA NA FOTOGRAFIA.

No hino da Penitenciária de Mulheres de Bangu, o valor dado ao trabalho como elemento essencial a uma vida honesta, preenchida e estruturada é evidente. Trabalhar no cárcere para voltar ao convívio social sem vícios, e de preferência tendo adquirido habilidades que permitissem o sustento extramuros e evitassem o retorno a modos de vida ilícitos ou pouco dignos era, em tese, uma das funções do encarceramento feminino. A valorização do trabalho fazia parte do projeto de ressocialização que deveria ser colocado em prática nos estabelecimentos prisionais femininos, uma vez que este não somente era importante para que as mulheres presas aprendessem um ofício que pudessem praticar quando estivessem em liberdade, mas também para preencherem o tempo no interior do cárcere e inculcar-lhes uma ética do esforço. Havia, por parte dos penitenciaristas, administradores e das Irmãs o incentivo ao trabalho carcerário voltado, no caso das mulheres, para tarefas consideradas tipicamente femininas dentre elas a costura, o bordado, os trabalhos domésticos e o magistério. Os ofícios aprendidos e praticados no cárcere deveriam ser 
passíveis de reprodução no mundo externo estando em consonância com as demandas sociais de trabalhos femininos.

Combater o ócio e ensinar ofícios às mulheres eram as principais funções do trabalho prisional feminino. Na Exposição de Motivos do Regimento da Penitenciária de Mulheres e do Sanatório Penal de Tuberculosos de Bangu, Lemos Britto destacava que a "promiscuidade e ociosidade são por bem dizer sinônimos de degradação, de corrupção e de ignomínia. O trabalho é tônico da vida física e moral do indivíduo (...). Ele constitue uma ginástica do corpo e do espírito" (APB, 1942d, pp.38 e 39). O Trabalho deveria ser útil e agradável, de modo a ocupar o tempo penitenciário de maneira educativa. Segundo o texto, "não ter um trabalho é ter um castigo", uma vez que a ociosidade era degradante. O Guia das Internas da Penitenciária de Mulheres de Bangu, no item denominado "trabalho" previa que:

é preciso habilitar-se para ganhar honestamente a vida. O trabalho é belo pela intenção que o anima, - belo pelo fim que tem em vista. Ele não tem em vista unicamente adquirir recursos, mas também evitar muitos males e vícios. 'a ociosidade é a mãe de todos os vícios. É preciso trabalhar mesmo quando o trabalho é humilde e custoso, mesmo quando pede paciência, atenção,esforço, perseverança e coragem. (...) É útil e muito proveitoso aprender todos os afazeres domésticos, desde a sala até a cozinha, - corte, costura, bordados, limpezas, arranjos domésticos etc. (RIO DE JANEIRO, 1983, p. 82)

Os afazeres manuais, como a costura e o bordado, eram considerados tarefas femininas por excelência ${ }^{84}$, "peculiares a todos os estabelecimentos penais de mu-

84 Em pesquisa histórica sobre o asilo do Juqueri, Maria Clementina Pereira Cunha ressalta situação semelhante encontrada nesta instituição, que também recomendava às mulheres trabalhos "tipicamente femininos". De acordo com a pesquisadora: "para elas [cabe] a reclusão do trabalho doméstico encerrado entre as paredes daquela 'casa' coletiva. A agulha, o fogão, a sala de trabalhos manuais, espaços fechados condizentes com a idéia da normalidade da condição feminina” (Cunha, 1988, p. 89). Nesse mesmo sentido, no já mencionado relatório feito por Ramos de Azevedo à época da construção do Juqueri, que consta no processo de tombamento do Hospital, o arquiteto aponta que os homens internados poderiam "exercitar suas aptidões" nas "officinas de applicação", enquanto às mulheres eram reservados "os trabalhos de agulha e outros", que deveriam ser realizados "nas salas de descanso". Enquanto os homens trabalhavam, nas oficinas, as mulheres, na sala de descanso, "passavam o tempo" com os trabalhos manuais (RAMOS DE AZEVEDO, Apud, Secretaria de Estado da Cultura, Processo 
lheres", como ressaltava um trecho do plano da penitenciária de mulheres elaborado pela Inspetoria Geral Penitenciária, publicado no primeiro volume dos Arquivos Penitenciários do Brasil, em 1940, que traçava as diretrizes para a penitenciária feminina de Bangu. São constantes, nos documentos pesquisados, menções aos trabalhos manuais desenvolvidos pelas detentas. O relatório da Penitenciária Central do Distrito Federal, do ano de 1951, aponta que "funcionou, com regularidade, a secção de trabalhos manuais, compreendendo bordados variados, tricô, enfeites, flores artificiais, etc.", tendo sido fabricadas, naquele ano, um total de 409 peças de trabalhos manuais; e ressalta que "muitas presas têm habilidades para tais trabalhos, executando-os com delicadeza e perfeição" (AE, fev/mar de 1952, p. 66). Um dentre muitos exemplos de citações dos trabalhos manuais realizados pelas detentas, pode ser pontuado na fala do repórter da Revista $A$ Estrela sobre o "capricho feminino", com o qual fora recebido na Penitenciária de Mulheres de Bangu. Em suas palavras:

saboreando o café que nos foi oferecido, em xícaras de porcelana e colheres de prata, vimos trabalhos de agulha mimosos, feitos pelas mãos santas das Irmãs, secundadas pelas mãos habilidosas das presas, roupas para crianças de todas as idades, flores de veludo, almofadas, lenços, toalhas de chá e de mesa, obras artísticas (AE, junho de 1945).

Em especial, as menções à costura e aos artesanatos aparecem nos documentos pesquisados tanto como atividades realizadas nos momentos de lazer quanto desempenhadas como trabalho penitenciário, uma vez que o trabalho manual era constantemente considerado mais um passatempo que propriamente um trabalho. A constante desvalorização do trabalho feminino e a subestimação do esforço dispendido nas atividades manuais e domésticas possivelmente contribuíram para a percepção de que o artesanato prisional não fosse propriamente um trabalho. No entanto, nesse contexto, o mais importante era permitir à mulher aprender ou desenvolver

24601/1986, p. 23). 
habilidades passíveis de serem reproduzidas na "vida livre", em especial aquelas vinculadas ao mundo doméstico e aos espaços femininos, sendo esse o sentido principal atribuído à palavra "trabalho", portanto menos vinculada ao lucro e mais atrelada à ocupação do tempo e ao aprendizado de tarefas. Nesse sentido, na descrição da Sala de Costuras da Penitenciária de Mulheres de Bangu, transcrita n’ A Estrela, o repórter pontuava que:

uma das ocupações mais habituais da mulher é a costura, e na penitenciária elas podem praticá-la quase que como no lazer. Uma sala ampla, dotada de maquinismo moderno, movido à eletricidade, serve para suprir a distância do lar ou às vezes [originar] mais uma criatura portadora dessa prenda. É o trabalho mais freqüente; outros há como: bordados, enfeites, flores, mas são praticados em lugares sem tantas preocupações de ofício, além de culinária, confecções de doces; todos os ensinamentos são ministrados pelo princípio doméstico, mas podem ser assimilados como meio de vida (AE, junho, 1951, pp. 4 e 5).

Em um contexto que privilegiava a individualização da pena como método preferencial para o tratamento penitenciário, era crucial que cada mulher pudesse trabalhar naquilo que lhe seria útil ao sair do cárcere, ou seja, naquilo que melhor propiciasse sua reinserção social. Assim, a mulher que não precisasse trabalhar, dada a sua condição social, deveria ocupar seu tempo com trabalhos voltados para o cotidiano doméstico e para o lazer feminino, não se preocupando com o lucro. Já a que precisasse trabalhar para garantir o próprio sustento ou complementar a renda familiar, deveria praticar tarefas domésticas como cozinhar e lavar/passar roupas, para que pudesse posteriormente trabalhar em casas de família, bem como em atividades fabris como a tecelagem e outras. Além disso, dentro das possibilidades penitenciárias, os "dons" e as "características naturais" femininas deveriam ser respeitados de modo a possibilitar que cada detenta se ocupasse daquilo que melhor soubesse fazer. Tal divisão de tarefas que privilegiava habilidades e dons possivelmente justificava a divisão de trabalho de acordo com a classe social e outras clivagens no interior do cárcere, cabendo às mulheres mais pobres os trabalhos mais pesados do cotidia- 
no prisional, enquanto às de classe mais alta deveriam se ocupar dos trabalhos manuais, uma vez que eram, de acordo com o plano da penitenciária de mulheres elaborado pela Inspetoria Geral Penitenciária, "inadaptáveis a outros serviços" (APB, 1940, p. 89). Segundo Lemos Britto,

é de temer que as mulheres, em sua maioria pobres, pois a nossa criminalidade feminina em geral vai buscar nas classes inferiores os elementos de que se nutre, adquirindo hábitos e aprendendo uma profissão incompatível com sua condição econômica e social não mais tolere o meio humilde de onde saiu e a ele não queira mais submeter-se, gerando-se desse repúdio outros problemas igualmente sérios (LEMOS BRITTO, 1943, p. 22).

O olhar do penitenciarista de que eram as mulheres pobres as que mais delinquiam ignorava a seletividade do sistema prisional, e o temor de que a mulher capacitada não tolerasse mais o meio de onde veio e se rebelasse contra ele, justificava o tratamento diferenciado por classe e tipos de mulheres presas, o que vai ao encontro da escala de criminosas por ele traçada e da importância do tratamento penitenciário individualizado. Em manifestações como estas, a igualdade formal garantida em lei contrastava com a prática cotidiana de exclusão social e econômica institucionalizada no Brasil.

Na continuação da descrição da Sala de Costuras da Penitenciária de Mulheres de Bangu, o repórter ressaltava:

é interessante observar-se que o objetivo das dirigentes é despertar a espontaneidade das preferências, aproveitando as atitudes femininas, a delicadeza, a sutileza da mulher, sem que, entretanto, se force alguém, ou seja, a paciente obrigada ao que a própria formação profissional não aceita. Se não pode existir a individualização, meio ideal de tratamento, a inclinação, as tendências naturais da pessoa são aproveitadas e sutilmente adaptadas dentro das disponibilidades materiais (AE, junho de 1951 pp. 4 e 5). 
Nesse sentido, Lemos Britto, na Exposição de Motivos do Regimento da Penitenciária de Mulheres e do Sanatório Penal de Tuberculosos de Bangu, ressaltava que o trabalho prisional deveria atentar para a "constituição física" e "profissão anterior da reclusa”, uma vez que "não é possível, nem aconselhável, impor a uma lavadeira profissional um trabalho de arte, ou a uma mulher culta o trabalho de campo. Já é conquista antiga essa de acomodar o trabalho à profissão do sentenciado" (APB, 1942d, p. 39). Por outro lado, ao mesmo tempo em que o documento alertava que era necessário atentar para as habilidades de cada mulher, deixava claro que quaisquer dúvidas referentes ao trabalho prisional feminino deveriam ser superadas, uma vez que era fundamental que as mulheres trabalhassem no cárcere, pois o trabalho era uma realidade cada vez mais patente na sociedade do período. De acordo com o texto da Exposição de Motivos:

na vida livre ela [a mulher] é hoje a forte concorrente do homem, mesmo os mais duros trabalhos lhe são familiares. Ví em Leixões, Portugal, mulheres carregando pelas escadas de corda do navio, bagagens e carvão. E vi em estradas européias mulheres britando pedra. As fábricas de fiação e tecido são servidas por elas. Há mulheres que trabalham na lavoura e cuidam de gado. Tôdas as profissões, desde que as mesmas se habilitem, podem ser por elas adotadas. Das mais delicadas às mais rudes" (APB, 1942d, p. 39).

No entanto, de nada adiantaria ensinar às detentas ofícios que, seja por falta de oportunidade ou por não corresponder a um "dever ser" feminino, não conseguissem realizar fora do cárcere, o que fica claro no plano da penitenciária de mulheres, que traçava as diretrizes de como deveria ser a penitenciária feminina de Bangu e no qual havia a previsão de que a lavanderia da penitenciária deveria "aproveitar as mulheres em lavar, gomar e passar a ferro roupas pelos métodos empregados em família, e não por meio de complicados aparelhos de que não poderão dispor quando liberadas" (APB, 1942d, p. 89). Já na Exposição de Motivos do Regimento da Penitenciária de Mulheres e do Sanatório Penal de Tuberculosos de Bangu, Lemos Britto argumentava contra a construção de uma penitenciária agrícola feminina, como previ- 
ra Cândido Mendes nas décadas de 1920 e 1930, uma vez que estaria em desacordo com a realidade social/laboral do período. Em suas palavras:

no Rio seria absurdo colocar em penitenciária agrícola as nossas sentenciadas, porque estas procedem, em sua quase totalidade, das profissões domésticas, das fábricas e das oficinas. Acresce que o número de mulheres é diminuto para permitir por enquanto qualquer organização eficiente de trabalho. (...) Demos preferência à costura e malharia por serem as mais úteis e produtivas. Elas poderão produzir para o próprio e para o vizinho estabelecimento. Quanto aos serviços externos, fixamo-nos na jardinagem, na horticultura e na avicultura, os quais poderão bastar às necessidades do estabelecimento em hortaliças, legumes, aves e ovos" (APB, 1942d, p.40).

Ainda em 1933 o Anteprojeto do Código Penitenciário ${ }^{85}$, em seu artigo 330, previa que no Reformatório Federal para Mulheres, que nunca "saiu do papel", deveriam ser estabelecidas "oficinas de costura, lavanderia e engomagem de roupas, destinadas a servir ao estabelecimento e a particulares ou a repartições oficiais". "Trabalhar para fora”, função exercida por mulheres de classes baixas das cidades em crescimento, era ação oficialmente prevista no Anteprojeto do Código Penitenciário como tarefa que seria realizada no interior do estabelecimento prisional feminino.

Apesar de nunca ter sido promulgado, o Anteprojeto plantou sementes que germinariam mais tarde nos estabelecimentos prisionais. Nos documentos pesquisados, há menções de que em alguns presídios femininos, como em Bangu e no pavilhão destinado a mulheres do Presídio de Pernambuco, tarefas condizentes com afazeres domésticos comumente atribuídos às mulheres, como as de lavanderia, eram realizadas pelas detentas para suprir necessidades dos próprios estabelecimentos, de outros, como os masculinos, e de demais órgãos públicos.

Na Prisão de Pernambuco estabeleceu-se um regime de trabalho para as detentas da ala feminina, denominada prisão de mulheres, responsabilizando-as pela

85 Diário Oficial, 31 de agosto de 1933, pp. 17194 e 17195. 
lavagem das roupas dos funcionários do presídio, de modo a sair "da ociosidade forçada em que viviam antigamente" (APB, 1942a, p. 144). Já um relatório prisional de 1954, publicado em A Estrela, ressaltava que havia "grande movimento" nas oficinas de costura da Penitenciária de Bangu, onde foram feitos, naquele ano, 403 uniformes e 804 peças ao Serviço de Assistência Social da Penitenciária Central e lavadas 17.003 peças do Sanatório Penal; 1.297 peças do Destacamento Policial; 14.038 peças da Comunidade e 16.904 peças das Internas.

Vale ressaltar que havia uma diferença legalmente instituída em relação ao trabalho masculino e feminino durante o cumprimento de pena - enquanto aos homens era prevista a possibilidade de trabalho interno e externo, independentemente do cumprimento de regime fechado, semi-aberto ou aberto ${ }^{86}$, às mulheres havia a ressalva de que o trabalho deveria ser "interno", segundo o parágrafo $2^{\circ}$, do artigo 29 do CP de $1940^{87}$, previsão que apenas foi alterada em $1977^{88}$. Assim, as mulheres não poderiam trabalhar para além dos muros das prisões, devendo o trabalho ao ar livre ser interpretado como "trabalho interno", de acordo com os penitenciaristas, e não considerado "trabalho externo" que era fora do estabelecimento prisional.

Nesse sentido, além dos serviços realizados nas oficinas, os estabelecimentos prisionais femininos pretendiam promover algum tipo de trabalho ao ar livre, como de avicultura e horticultura. Victorio Caneppa, em relatório sobre o sistema prisional do Rio Grande do Sul, feito em 1940, ao mencionar o Instituto Feminino de Readaptação Social de Porto Alegre, ressalta haver "uma grande horta, onde [as internas] retiram a verdura e os legumes necessários à sua alimentação" (APB, 1941a, pp. 257 e 258). A importância do trabalho ao ar livre aparece nos planos de espaços penitenciários femininos que deveriam ser implementados na Bahia e em Pernambu-

\footnotetext{
$86 \quad$ Parágrafos $1^{\circ}$ e $2^{\circ}$ do artigo 30 do CP de 1940.

87 "as mulheres cumprem pena em estabelecimento especial, ou, à sua falta, em seção adequada de penitenciária ou prisão comum, sujeitas a trabalho interno”.

88 A lei 6416 de 24 de maio de 1977 alterou o parágrafo $2^{\circ}$ do artigo 29 do CP, possibilitando o trabalho externo às mulheres. Segundo a redação do novo parágrafo "as mulheres cumprem pena em estabelecimento especial ou, à sua falta, em seção adequada de penitenciária ou prisão comum, sujeitas a trabalho interno, admitido o benefício do trabalho externo".
} 
co, bem como na exposição de motivos do regimento da Penitenciária de Mulheres de Bangu. De acordo com Lemos Britto, relator deste documento:

o regime será aplicado nas oficinas, nas classes escolares, nos serviços internos, nas dependências, na jardinagem, na criação de aves e nas hortas ou pomares, porque é sobretudo pelo trabalho que pretendemos recuperar esses elementos sociais tresmalhados do dever e da ordem. Urgia, aliás, assimilar o 'trabalho interno', que é o que o novo Código Penal prescreve para as mulheres sentenciadas, o que se realiza nas hortas, nos jardins, pomares e aviários da Colônia, sob pena de não poderem as reclusas trabalhar ao ar livre (APB, 1942d, p.32).

A impossibilidade de realização de trabalho externo tornava a clausura carcerária feminina, nesses termos, mais rigorosa que a masculina. Se os homens deveriam exercer no cárcere principalmente atividades técnicas que os permitissem se empregar, mais tarde, em indústrias e área de serviços, a possibilidade de trabalho para além do espaço prisional era uma maneira de garantir e estimular essa (re) inserção. Já no caso das mulheres, era importante manter as internas sob controle constante, já que elas, durante o tempo em que estivessem presas, deveriam passar por um tratamento moral, no qual eram recomendados o recato, o silêncio, o trabalho e a dedicação. Sair da prisão para trabalhar fora poderia significar uma contaminação pelo mundo externo, algo perigoso para o plano de reabilitação moral para aquelas que transgrediram. Possivelmente, para o legislador do Código Penal de 1940 o lugar da mulher era dentro de casa, afirmação que justifica a ressalva da lei e guiou toda a estruturação dos estabelecimentos prisionais femininos nos seus primeiros anos. Segundo Lemos Britto, o pequeno investimento em "trabalho de larga escala" se dava justamente pelo baixo número de mulheres presas e pela incapacidade de conciliar "mulheres de diversas categorias e níveis mentais e culturais" em um trabalho único (LEMOS BRITTO, 1943, p. 20). A proposta de cautela com os trabalhos aprendidos no cárcere era uma declaração de manutenção do status quo social, um dos principais aspectos responsáveis pela marginalização social de mulheres pobres. 


\section{Arquitetura Prisional}

Conforme já dito anteriormente, de todas as primeiras instituições prisionais femininas, apenas a Penitenciária de Mulheres de Bangu foi construída para tal fim, tendo sido as demais instaladas em prédios adaptados para abrigar as deten-

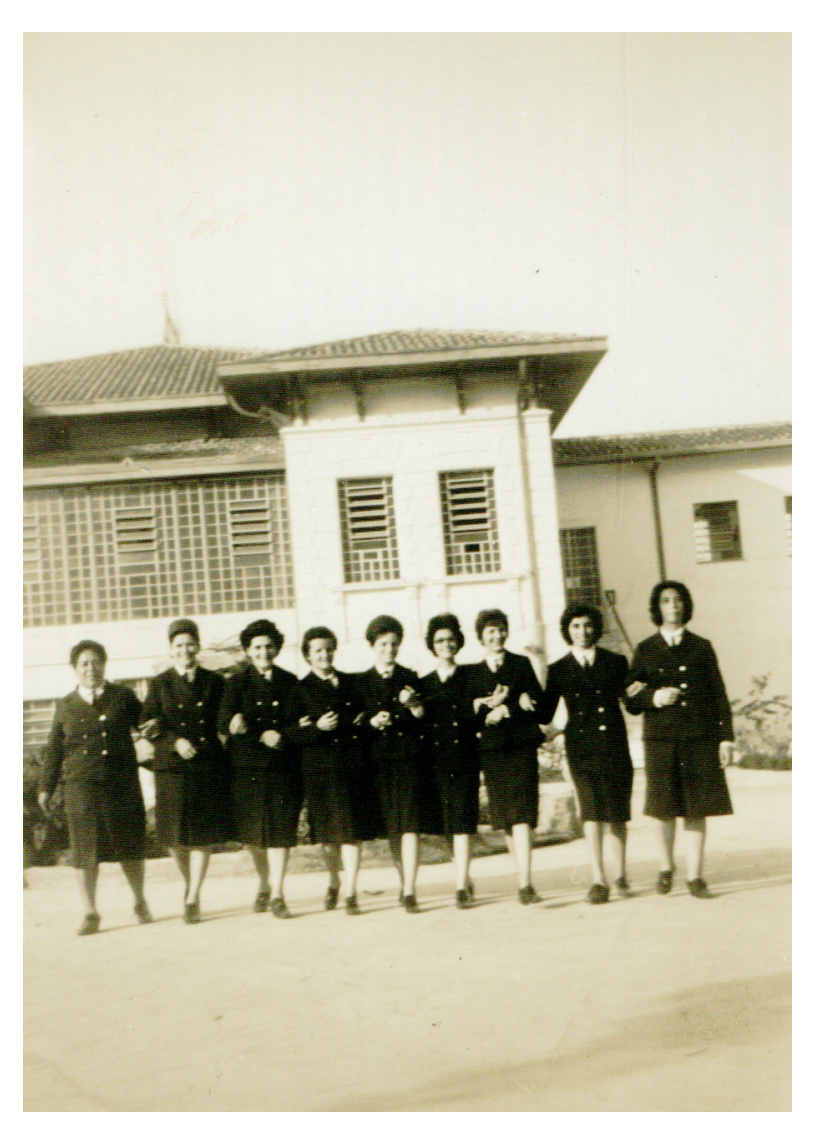

GRUPO DE FUNCIONÁRIAS NÃO RELIGIOSAS

NO PRESÍDIO DE MULHERES DE SÃO PAULO. AO

FUNDO, A CASA DO ADMINISTRADOR, PRÉDIO

NO QUAL FOI INSTALADA, NO ANO DE 1942. tas. Assim ocorreu no Instituto de Reabilitação Social, em Porto Alegre, erguido em uma antiga casa senhorial e no Presidio de Mulheres de São Paulo instalado na residência dos diretores da Penitenciária do Estado no terreno desta, no bairro do Carandiru. Apesar da grande diferença entre a instauração do estabelecimento de Bangu e dos demais, as preocupações presentes na organização dos prédios para abrigar as encarceradas eram muito semelhantes entre si e estavam em consonância não só com o discurso de humanização da pena que permeava os planos de reformas penitenciárias em curso no país, mas também com a função esperada do aprisionamento feminino. $\mathrm{O}$

aproveitamento do espaço, a divisão das alas, as organizações celulares, a aparência do prédio eram preocupações que apareciam nos debates de penitenciaristas e daqueles envolvidos na construção e/ou instalação dos estabelecimentos prisionais femininos à época de sua criação. 
A superação do estigma de masmorras que compunha o imaginário sobre prisões era um ponto recorrente na maioria dos discursos sobre arquitetura carcerária. A modernidade penitenciária passava, necessariamente, pela modernização dos prédios e pela distribuição das pessoas nos espaços prisionais, criando-se tipologias específicas para este novo programa arquitetônico, que havia surgido no século XIX, nos países mais progressistas. Se a pena tinha como função principal alegada a recuperação do indivíduo para a vida em sociedade, a salubridade do ambiente prisional era fundamental para a realização desta missão. Além disso, no cenário do Brasil civilizado que se pretendia construir, cárceres modernos, humanizados e higienizados funcionariam como vitrines da Nação. Lemos Britto, ao citar o jurista uruguaio Irureta Goyena, para quem "a readaptação ou reforma dos sentenciados 'é também uma questão de arquitetura'”, deixava claras as razões pelas quais o Conselho Penitenciário tanto discutia arquitetura prisional (APB, 1942d, p.31).

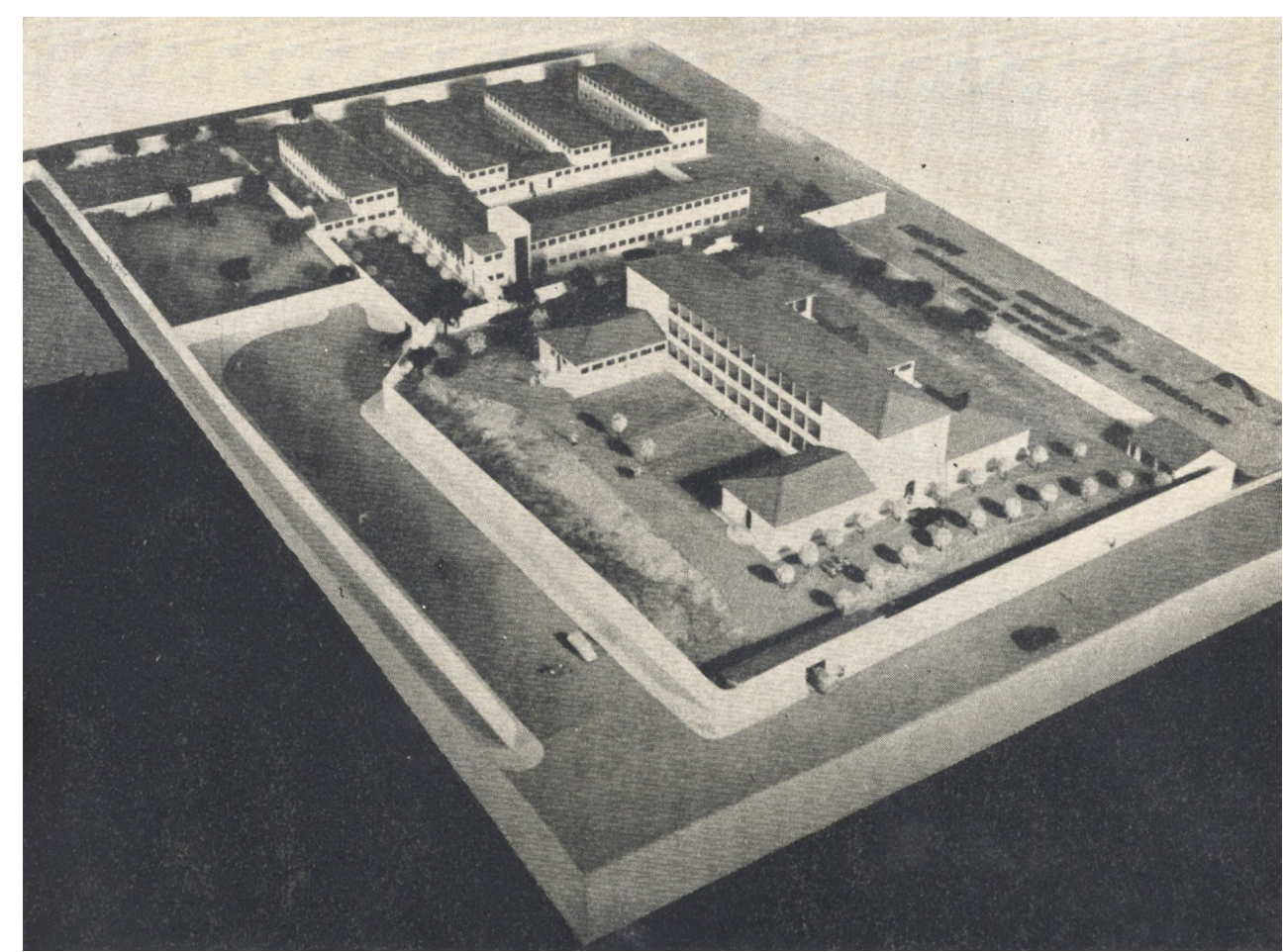

PLANTA ORIGINAL DO COMPLEXO DE BANGU, PUBLICADA NOS ARQUIVOS PENITENCIARIOS DO BRASIL, EM 1942. 
Os debates em torno da penitenciária de Bangu, por ter sido construída especialmente para abrigar mulheres, são ilustrativos do que se pretendia como modelo ideal para o aprisionamento feminino no período. Nesse sentido, as instruções para a elaboração da planta do estabelecimento, escritas em 1940, elucidam alguns pontos importantes que deveriam ser observados de modo a garantir a concretização de um ideal penitenciário. Dentre eles estão: I) o investimento em um modelo penitenciário misto, com trabalho agrícola - compreendendo serviços de jardinagem, horta, pomar, avicultura - e industrial - voltado para o trabalho doméstico e aprendizagem de atividades rendosas adequadas ao perfil das detentas; II) ter espaço para abrigar, no mínimo, sessenta condenadas e vinte processadas, e garantir área para a construção de novas alas, se necessário; III) estruturação de refeitório comum, mas que permitisse a separação das reclusas em diferentes grupos; IV) dormitórios

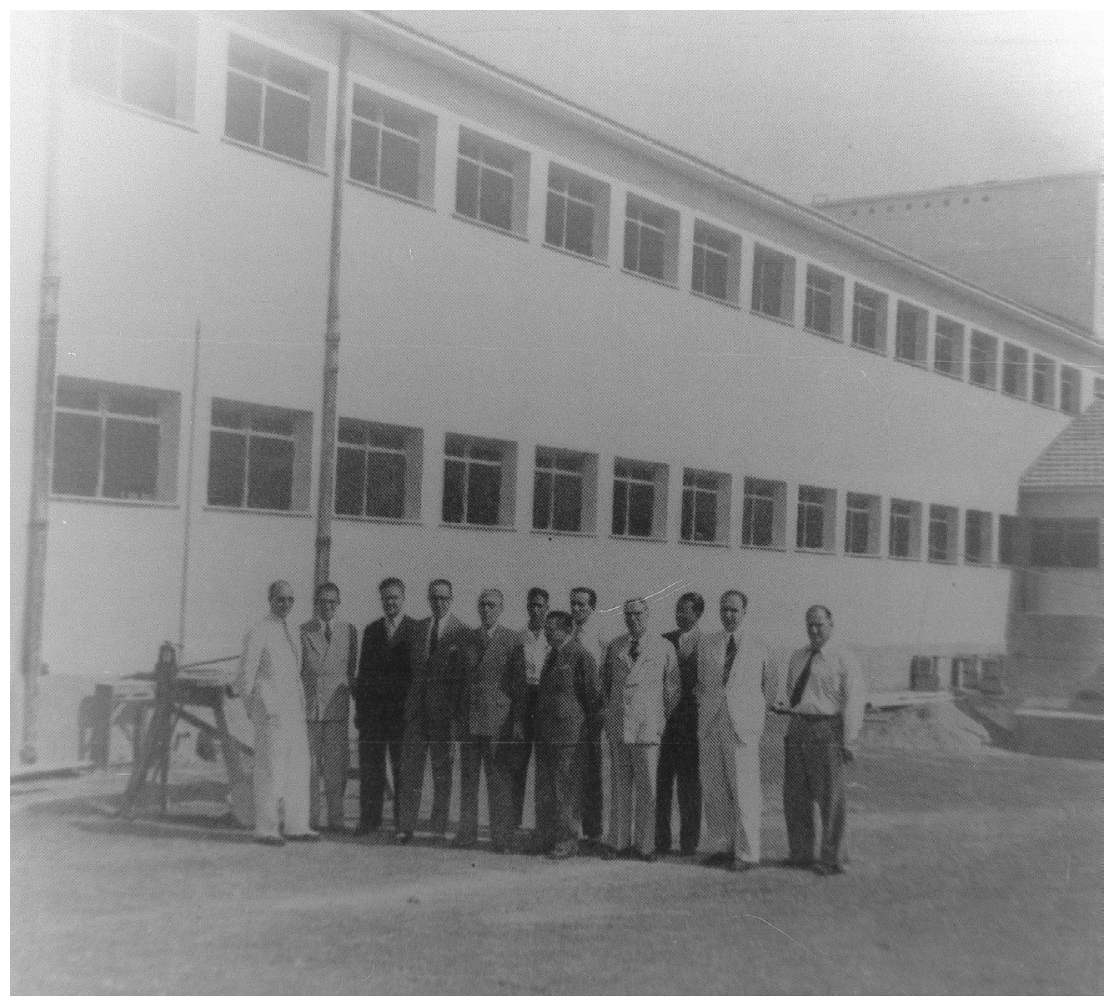

EQUIPE DO CONSELHO PENITENCIÁRIO DO DISTRITO FEDERAL EM VISITA ÀS OBRAS

DA PENITENCIÁRIA DE MULHERES DE BANGU E DO SANATÓRIO PENAL, EM 1942. PUBLICADA NOS ARQUIVOS PENITENCIÁRIOS DO BRASIL (APB, 1942A, S/P). 
coletivos e individuais, que deveriam ser organizados pela administração de acordo com o regulamento; V) isolamento entre processadas e condenadas; VI) espaço para abrigar crianças e suas mães processadas e sentenciadas, em especial em período de aleitamento; VII) construção apenas dos muros indispensáveis, que não passassem a impressão das muralhas de presídios, mas que cumprissem com suas funções de segurança e isolamento espacial; VIII) separação de espaço para realização de exercícios físicos; IX) construção de uma sala de prontuário, identificação e gabinete fotográfico; de um anexo psiquiátrico com quatro células para observação; capela; cozinha; copa; de salas de oficinas para costura, bordado, fabricação de caixas de papelão e malharia; X) construção de residência separada do prédio principal para abrigar as administradoras; (APB, 1940, pp. 91 a 93).

Dentre esses pontos, alguns receberam atenção especial dos penitenciaristas e especialistas envolvidos na construção e/ou estruturação de estabelecimentos prisionais femininos. Vale destacar o debate em torno da presença/ausência de muros e grades nos estabelecimentos prisionais. Para muitos penitenciaristas, como lemos Britto, Caneppa e Lyra, e outros entusiastas do tema, a ausência de muros estava em consonância com uma visão pedagógica de prisão predominante nas décadas de 1940 e 1950. Prender para educar e ressocializar era o lema principal dos estabelecimentos no período. Os muros e grades lembravam masmorras e passavam, externamente, uma imagem negativa das penitenciárias. Quanto menos os estabelecimentos apresentassem aspecto de prisão e mais semelhanças tivessem com escolas e internatos, melhor seria a sua imagem. O investimento na ausência de muros e grades compunha o plano de humanização e modernização institucional que atingia igualmente outros estigmas penitenciários, como os uniformes zebrados. Nesse sentido Lemos Britto ao mencionar a reforma penitenciária em curso frisava que a roupa listrada, assim como o número do preso, o cabelo raspado, as altas muralhas, as largas paredes e os pesados varões de ferro, eram preconceitos penitenciários dos quais a prisão deveria se livrar (APB, 1946, p.43).

No texto, o jurista ressaltava, ainda, a postura da Inspetoria Geral Penitenciária, que era favorável à abolição das pesadas grades e muros, tendo inclusive ga- 
rantido que os estabelecimentos prisionais construídos em Bangu - a Penitenciária de Mulheres e o Sanatório Penal - tivessem muros circundantes que não se assemelhavam aos tradicionais modelos de muralhas prisionais (APB, 1946, p.43). Em relação a esses estabelecimentos, a Inspetoria Penitenciária recomendava, ainda em 1940, que houvesse a

(...) exclusão das muralhas e das pesadas grades que ficaram como imposição de um passado já em parte repudiado pela nossa legislação penal e penitenciária, exceção dos regulamentos dos presídios, que precisamos remodelar ( $A P B, 1940$, p.89).

Além dos argumentos de humanização penitenciária, havia, em relação à presença de muros e grades nos estabelecimentos prisionais femininos, o reforço de um estereótipo de passividade feminina, uma vez que o perigo de fugas em estabelecimentos prisionais para mulheres não era uma preocupação, o que pode ser percebido nas palavras de Lemos Britto, em 1939, relativas ao planejamento de um reformatório provisório para mulheres no Estado da Bahia:

à exceção do muro destinado a defender o estabelecimento da curiosidade pública e de qualquer ligação direta e indireta com o depósito de presos, o arquiteto evitará tudo quanto signifique preocupação de dar ao reformatório aspecto e segurança de prisão, pois não há perigo de que as mulheres ai reunidas pretendam amotinar-se e evadir-se em massa, forçando os obstáculos naturais opostos a sua comunicação com o exterior” (APB, 1942b, p.314).

A ausência de muros evitaria, ainda, que os estabelecimentos prisionais fossem identificados de imediato, fato importante para evitar a rotulação negativa a eles atribuída. Fazia parte da humanização penitenciária garantir que os presídios não se assemelhassem a presídios - um complexo eufemismo que buscava confundir tais estabelecimentos com espaços educacionais. Nesse sentido, vale ressaltar descrição feita em relatório sobre o sistema prisional gaúcho, segundo a qual, 
o Reformatório de Mulheres Criminosas funciona num velho prédio senhorial da Avenida Getúlio Vargas nº 765 , sem nenhum aspecto de presídio na sua configuração arquitetônica, ao ponto de não permitir ao transeunte identificá-lo como tal. As crianças do Grupo Estadual '13 de Maio’ que funciona ao lado, e mesmo os moradores do Menino de Deus, no geral não suspeitam que ali, naquele melancólico casarão, de estrutura sólida no mau gosto de um estilo impreciso, de arquitetura intermediária - há o drama de cêrca de 50 mulheres excluídas da vida social, algumas sob o peso de 20 e até 30 anos de prisão (APB, 1942d, p. 259).

No trecho selecionado é possível contrastar a inocência das crianças com o "drama" das internas, escamoteado pela fachada. Aparentemente o "drama" não é transposto para a rua, uma vez que não há, ao menos arquitetonicamente, a estigmatização de quem habita a casa, "que nada lembra uma prisão".

Já nas páginas d'A Estrela é possível perceber o esforço do repórter para ressaltar a ausência de grades na Penitenciária de Mulheres de Bangu, bem como para mostrar que as grades eficientes seriam antes morais que físicas. Segundo descrito:

na curiosidade do repórter já há muito tempo morava a vontade de observar uma grade para descrevê-la; seria mesmo um detalhe indispensável para um trabalho desse gênero, mas ele não teve a oportunidade - não há grades. Ocorreu-lhe, então, a idéia da segurança do presídio, a possibilidade de fuga ou mesmo um detalhe que pudesse ter escapado à visão do idealizador da planta. Entrou numa célula sentiu-se como seu habitante: ar puro, luz solar, roupagem branca, alva, tranqüilidade...pelas janelas basculantes divisou o muro que divide a rua da prisão. Não é possível que resida no coração do presidiário maior desejo que - Liberdade, mas aquele ambiente é apaziguador; o que mais prende é a consciência, o fato de haver praticado uma falta; há a convicção de sair dali com o mal reparado e a alma corrigida - voltar ao ponto normal, à sociedade, se não quizermos dizer - o direito de ser livre (AE, junho de 1951, pp. 7 e 8). 
Há uma clara preocupação em desestigmatizar o cárcere como espaço de suplício e de mostrá-lo como local de reconstrução moral e ressocialização. Para tanto, é possível pontuar, nos documentos pesquisados, um esforço de mostrar as penitenciárias como locais limpos e organizados, nos quais reinava a disciplina e a ordem. "Não parecer uma prisão" era um mérito que as modernas instituições prisionais deveriam alcançar. Às criaturas impuras e transgressoras um ambiente puro e acolhedor - essa era a imagem que as descrições dos presídios femininos apresentavam ao leitor.

A reprodução de um lar modelo, lugar sereno com ares de casa, parecia ser almejada pelas Irmãs e estimulada pelos que pensavam o cárcere feminino. Afinal, o local ideal para educar a mulher e preparar sua reinserção na sociedade era aquele que, em alguma medida, se assemelhasse ao seu futuro lar. $\mathrm{O}$ asseio do cárcere deveria ser reproduzido no lar real, o qual as ex-detentas, moralmente recuperadas, deveriam almejar e construir. Inúmeras são as descrições que buscam mostrar como a prisão de mulheres parecia antes uma casa que um cárcere. $\mathrm{Na}$ exposição de motivos do regimento da Penitenciária de Mulheres de Bangu, Lemos Britto apontava que:

tanto a inspetoria penitenciária quanto o S. O. deste Ministério tiveram a preocupação de tirar do reformatório de mulheres todo o aspecto externo e interno das prisões à moda antiga. Não há nele varões de ferro, paredes de pedra, pesadas portas chapeadas. Os pavilhões em seu conjunto não dão impressão de tratar-se de um cárcere. E as células são pequenos quartos onde haverá uma cama e um colchão e um móvel com diversas aplicações para o uso de suas habitantes (APB, 1942d, p.31).

A semelhança entre a Penitenciária de Mulheres de Bangu e uma "grande casa" também é ressaltada pelo repórter da Revista $A$ Estrela, em texto repleto de elogios ao estabelecimento, no qual o autor busca reforçar sua imagem de ambiente puro e organizado. Em suas palavras: 
a higiene e o bom gosto são sempre os fatores predominantes, aproveitam-se os cobertores de lã em dobras artísticas que enfeitam as camas; o aspecto não é de prisão. Se não fosse tão corriqueiro diríamos: parece um hospital - mas ainda não estaríamos certos, lembra-nos mesmo, numa visão geral - uma

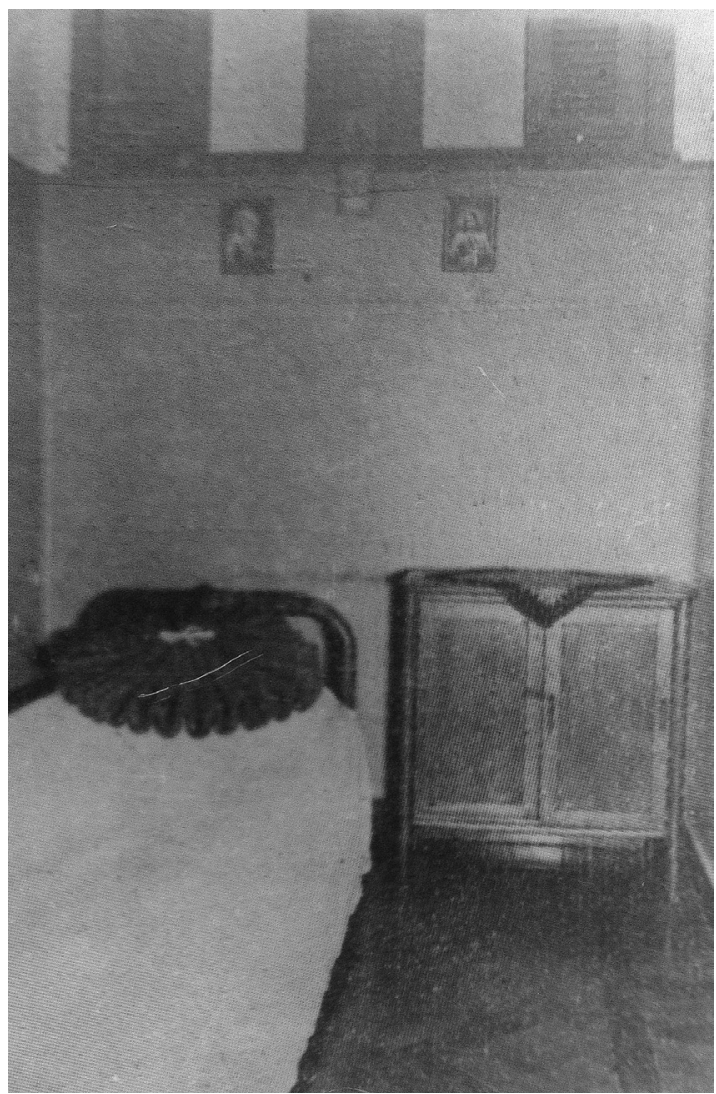

FOTOGRAFIA DE CELA DA PENITENCIÁRIA

DE MULHERES DE BANGU. NÃO FICA

CLARO NA MATÉRIA SE PERTENCE A

UMA DETENTA OU A UMA IRMÃ (AE,

JUNHO DE 1951, S/P). grande casa onde residem muitas pessoas (AE, junho de 1951, p. 7).

Em mais uma passagem, o repórter d'A Estrela segue comparando o cárcere feminino a um lar, onde inclusive as celas podem ser confundidas com quartos:

entramos pelo corredor que leva à galeria das células individuais. Estas mais parecem pequenos quartos de dormir caprichosamente arrumados. Não têm grades; possuem janelas um pouco mais altas do que as comuns por onde o sol e o ar penetram livremente. Depois vamos à sala de costura; uma sala ampla e bem disposta, onde as reclusas recebem aulas de prendas domésticas (AE, junho de 1951, p. 60).

A fórmula de receitar um lar para aquelas que nunca o tiveram ou nunca o valorizaram justifica e explica as representações convocadas nesses discursos. Se o lugar privilegiado da mulher ainda era, na década de 1940, o espaço privado, o encarceramento feminino deveria ser realizado em estabelecimento que remetesse ao privado, ao bom caminho. Nesse sentido, não é de se estranhar que o 
Presídio de Mulheres de São Paulo tenha sido erguido no prédio que servia de casa para os diretores da Penitenciária do Estado. O aproveitamento da casa, já construída no terreno da Penitenciária do Estado, foi uma solução temporária ${ }^{89}$ para o problema do aprisionamento feminino na cidade de São Paulo. Sob a égide dos discursos de humanização da pena de que as pesadas grades não eram necessárias, nem os altos muros, a casa dos diretores parecia um local ideal para abrigar a prisão de mulheres e cumprir, assim, as demandas do CP de 1940.

Elça Mendonça Lima, em sua pesquisa sobre as origens da Prisão Feminina no Rio de Janeiro, ao analisar o Guia das Internas do estabelecimento de Bangu ressalta, em relação à tentativa de reprodução do lar, que “(...) a prisão na sua temporalidade vai ser mais que um lar, por assim dizer, um lar na sua potência máxima”. Isso porque, de acordo com a autora, a presa deveria viver o doméstico o tempo todo, sendo o exercício de simulação do lar "exagerado" algo que ocuparia todos os espaços do sistema prisional. A criminosa, segundo Lima, era vista como uma "dona de casa imperfeita" que, ao transgredir, falhou em sua missão feminina, e que, portanto, deveria ser disciplinada para cumpri-la com primor ao sair do cárcere (LIMA, 1983, p. 71). Já em relação à ausência de grades, Lima associa as barreiras ideológicas a grades fictícias. Em suas palavras "não se tratava de torná-la [a prisioneira] tecnicamente inabilitada para fugir, mas da suposição de que bastaria que se instalassem mecanismos ideológicos, morais e psicológicos para que não fugisse”. A prisão de mulheres deveria, segundo Lima, se assemelhar antes a um internato do que a uma penitenciária (LIMA, 1983, p. 64).

Além disso, vale ressaltar que a presença das Irmãs como administradoras dos estabelecimentos prisionais também influenciou a organização do espaço. Em Bangu, por exemplo, a previsão da construção da capela apenas se deu após selado o convênio com as Irmãs, como ressalta a pesquisadora Elça Mendonça Lima (1983, p. 58). A estrutura da Capela construída em Bangu previa a presença, diante de Deus, das Irmãs - suas fiéis devotas -, das presas - mulheres que aprenderiam a conhecê-

89 Que durou até a década de 1970 com a construção da Penitenciária Feminina da Capital. 
-lo - e de pessoas da comunidade. Havia espaços separados para que cada um desses grupos pudesse assistir à missa. Nas descrições da Revista $A$ Estrela, a Capela sempre é citada de maneira divinizada - espaço inspirador, de meditação, pureza e reflexão. Na descrição de W.B.S., presidiário repórter d'A Estrela,

erigiu-se ao lado do Sanatório a penitenciária de mulheres e um templo à virgem! A fachada principal é opulenta; um duplo portal com vitral azul. A fachada lateral é de mais impotente efeito. Logo a seguir encontram-se amplas janelas; seguindo temos a porta lateral, muito singela e de estilo arcaico que dá entrada ao claustro das Irmãs. No interior do templo, grande número de quadros pequenos, representando Jesus, anjos, apóstolos, mártires etc. (AE, junho de 1945, s/p).

Em outro momento, o repórter tem o cuidado de explicar seu entusiasmo em relação à Capela, elucidando que tamanha exaltação em relação ao local se dá mais pelo que ele representa, do que propriamente por sua arquitetura:

o leitor haverá de dizer que muito nos admiramos da capela e que outras existem ainda muito mais sugestivas. Estamos de acordo, entretanto, devemos nos lembrar de que trata-se de uma prisão - um lugar geralmente esquecido, desprezado, quando justamente ali é que estão as criaturas que precisam efetivamente da sociedade; e por isso mesmo que encontrar uma obra dessas não é normal - é um passo além da concepção comum (AE, junho de 1951, pp. 8 e 9).

Por fim, merece destaque o debate relevante em torno do local onde as penitenciárias femininas deveriam se erguer. Teoricamente, e nesse ponto a maioria das opiniões de especialistas do período é convergente, os estabelecimentos para mulheres deveriam ser completamente isolados dos masculinos, de preferência não apenas em prédios separados, mas em terrenos distantes. De acordo com Lemos Britto, "a permanência de mulheres em estabelecimentos prisionais de homens, ainda quando 
em secções ou pavilhões especiais, contribui para exacerbar o instinto sexual desses com repercussão na disciplina e no trabalho" (APB, 1942b, p. 309). O risco de promiscuidade sexual e de "instigação de desejos", em especial dos homens, justificava a separação. Dentre os penitenciaristas, Lemos Britto foi o que mais se dedicou a debater a questão. Tanto em discurso proferido na Faculdade de Direito de São Paulo, denominado As Mulheres Criminosas e seu Tratamento Penitenciário, como na obra A Questão Sexual nas Prisóes, o autor se dedica à análise do tema.

Neste último, Lemos Britto era incisivo ao tratar da sexualidade latente, prestes a explodir a qualquer momento, que acometia os habitantes de uma prisão, afinal, em especial o homem, era um "animal sexual” com desejos e taras que deveriam ser controlados. Portanto, os perigos das misturas de detentos de ambos os sexos eram inúmeros e deveriam ser rigorosamente evitados. Para ilustrar os riscos da convivência comum, o autor pontuava:

quereis visitar esta prisão? Se sois homem, não deveis penetrar numa prisão de mulheres. Se sois mulher, não deveis transpor as grades de uma prisão de homens. Por que? Por uma razão muito simples; porque ireis abrir em chagas a alma adormecida dos que ahi vivem. (...) Eis porque as prisões onde se abrigam homens e mulheres, ainda que em compartimentos separados, acabam sempre transformadas em antros de baixa sexualidade (LEMOS BRITTO, 1934, p. 38).

Em 1934 Lemos Britto ressaltava que "nada perturba mais uma penitenciária que o odor di femina” (Lemos Britto, 1934, p. 38). Dialogava com Concepcion Arenal, superintendente geral dos serviços penitenciários da Espanha, para quem o odor di femina, "o cheiro feminino", mesmo sentido de longe, poderia desestabilizar uma penitenciária masculina, dado o seu potencial de despertar o desejo sexual nos homens. Concordando com a autora, Lemos Britto justificava a necessidade da completa separação entre os estabelecimentos. O perigo iminente da desordem deveria ser contido. Em suas palavras: 
em São Paulo o pavilhão de mulheres ficava na penitenciária de homens. Erro grave que foi preciso corrigir. Apezar de impossível o contacto das condemnadas com os reclusos, bastava a idéia de que ali perto viviam e dormiam mulheres para perturbar a vida do presídio. O canto das reclusas chegava até os homens, e os exasperava (LEMOS BRITTO, 1934, p.41).

O homem, ser mais sexualizado que a mulher, era a principal preocupação do penitenciarista. A mulher era antes um ser passivo que ativo, que trazia, nas palavras de Lemos Britto, “dentro de si a sua tragédia biológica”, ou seja, o fato da fecundação ser no corpo feminino fazia dela um ser muito mais contido que o homem em relação à sexualidade. Diante da "agressividade sexual do homem" a mulher era antes uma vítima que uma agente dos seus desejos (LEMOS BRITTO, 1934, p. 191 e 192).

No entanto, em 1943 Lemos Britto em As Mulheres Criminosas e seu Tratamento Penitenciário, em relação a um caso concreto, posicionava-se em favor da flexibilidade do rigor da separação de homens e mulheres em terrenos distintos. Ao falar do pedido feito por Cândido Mota, presidente do Conselho Penitenciário do Estado de São Paulo, de que interviesse contra a proposta de estabelecimento do Presídio de Mulheres de São Paulo no mesmo terreno da Penitenciária do Estado, Lemos Britto ressalta os motivos, ausentes em sua análise de 1934, pelos quais não apoiava Cândido Mota. Isso porque, decidira "não estorvar as soluções boas ou mesmo regulares por pretender as ótimas ou perfeitas”, uma vez que a experiência o havia ensinado a "considerar o perigo que para a reforma penitenciária no Brasil sempre representaram os adiamentos”. A prática falou mais alto que a teoria e o ideal se dissolveu em soluções factíveis (LEMOS BRITTO, 1943, p. 17). 


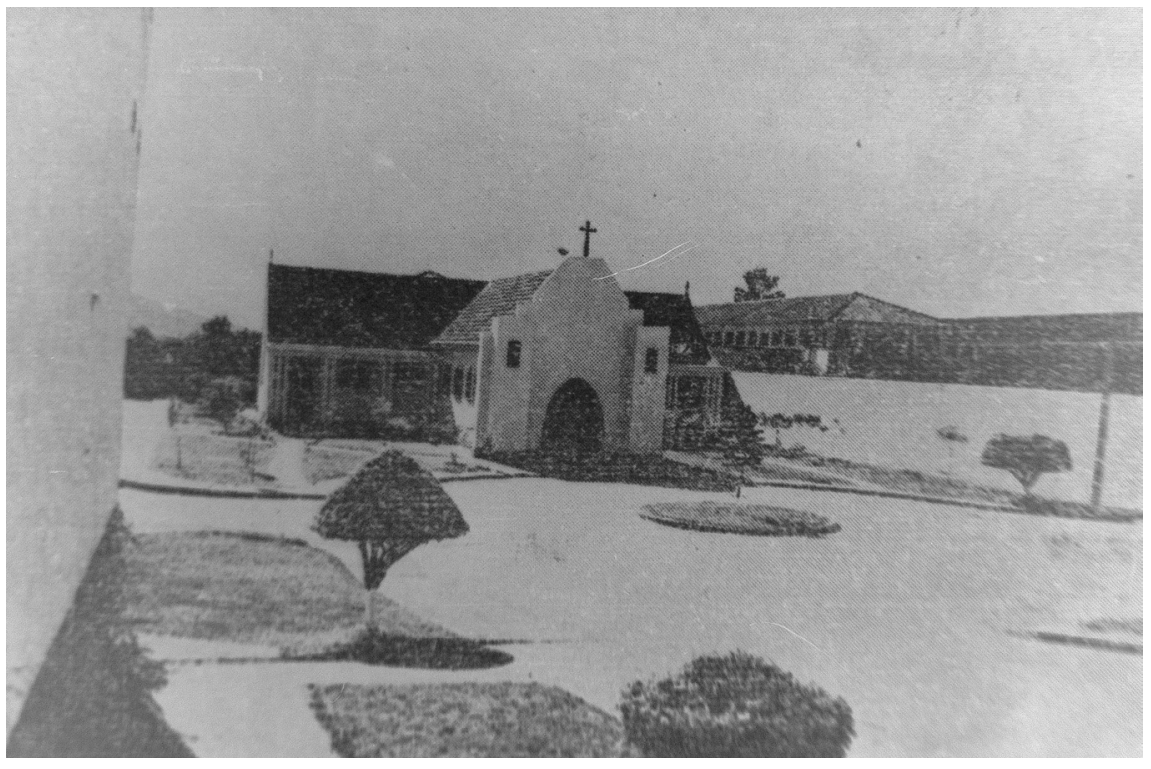

CAPELA DA PENITENCIÁRIA DE MULHERES DE BANGU, CONSTRUÍDA APÓS SELADO O CONVÊNIO COM AS IRMÃS DO BOM PASTOR D’ANGERS (AE, JUNHO DE 1951, S/P).

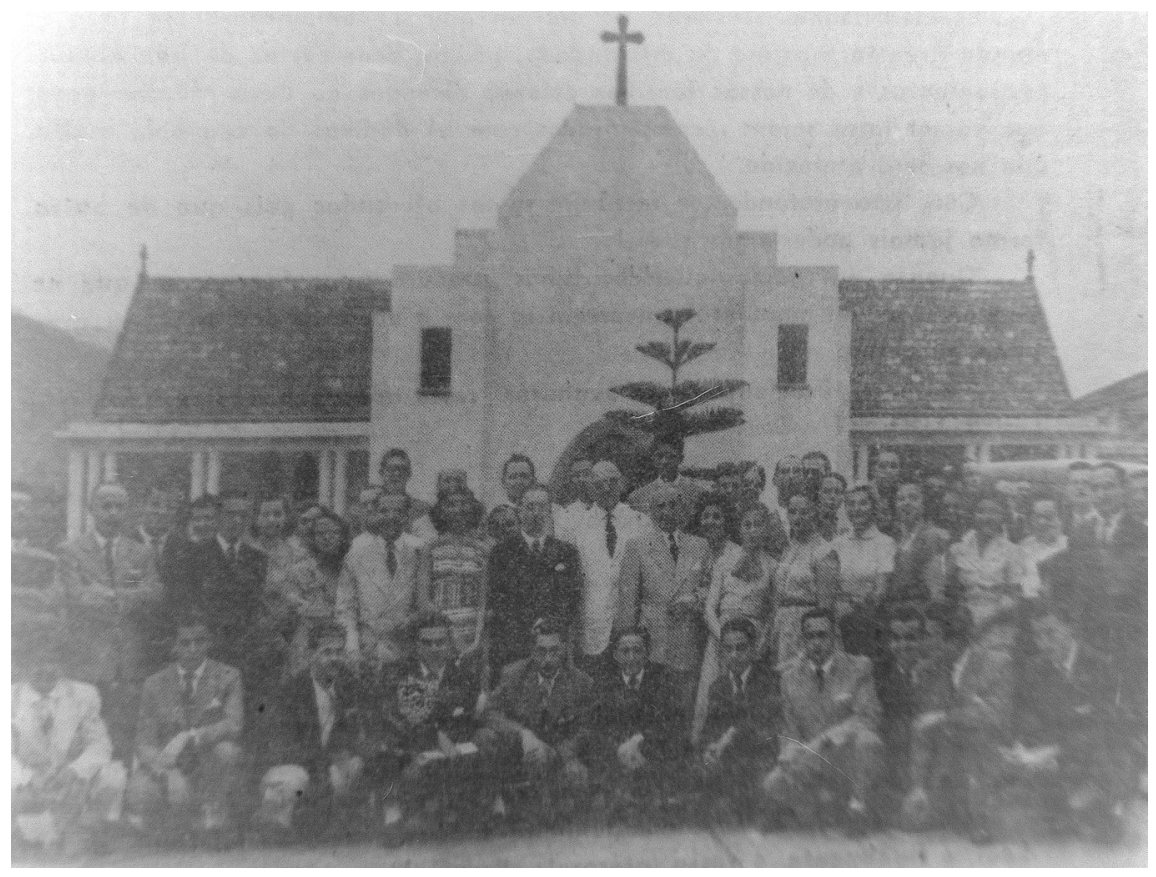

GRUPO DE ESTUDANTES DA FACULDADE NACIONAL DE DIREITO FOTOGRAFADOS EM FRENTE À CAPELA DA PENITENCIÁRIA DE MULHERES DE BANGU. NESTE DIA, 27 DE OUTUBRO DE 1951, OS ALUNOS DOARAM UMA TELEVISÃO PARA AS DETENTAS. (AE, NOV. E DEZ. DE 1951, P. 17). 
Lemos Britto advogava, então, pelo cumprimento da legislação, ressaltando que era a "separação material" que importava ao legislador, e não a separação dos terrenos. Em outros momentos, como nos relatórios para a reforma do sistema prisional baiano e pernambucano, Lemos Britto sugeriu que fossem construídos nos mesmo prédios dos estabelecimentos masculinos alas especiais femininas, totalmente isoladas das primeirsas. Sua solução se baseava na impossibilidade financeira desses Estados construírem estabelecimentos próprios, em lugares distintos, para as mulheres condenadas e processadas, que sendo poucas não justificavam esforço financeiro maior. Assim, em prol da reforma penitenciária e do cumprimento da legislação, Lemos Britto acabou por flexibilizar a regra de separação espacial por sexo, apesar dos argumentos veementemente contrários à prática, feitos anos antes. A defesa da construção de estabelecimentos penais femininos nas proximidades dos masculinos, sob argumentos de que representaria uma economia para o Estado e, portanto, facilitaria a criação desses espaços, foi amplamente criticada por Cândido Mota. Este, que em 1940 se posicionara sobre o tema um artigo publicado na Revista Penal e Penitenciária, denominado $E$ as Mulheres?, no qual ressaltava a urgência da criação de estabelecimentos prisionais femininos no país e da importância de distanciamento entre os espaços para homens e mulheres, se opôs a Lemos Britto quando este flexibilizou sua opinião acerca do tema.

\section{Maternidade e cárcere}

As detentas grávidas ou com filhos pequenos, em especial em fase de amamentação, também mereciam atenção dos penitenciaristas. De que maneira conciliar o cárcere - local que abriga pessoas que transgrediram leis - com a infância? Por mais que houvesse o esforço em retratar estabelecimentos humanizados, que se assemelhassem a lares, não era possível que as crianças permanecessem nos estabelecimentos prisionais por longos períodos, "cumprindo pena" ao lado de suas progenitoras. Por outro lado, a maternidade, vista como fenômeno que garantia "o futuro da nação" e como um potencial ativador dos latentes instintos femininos de cuidado e compaixão, não poderia deixar de receber a atenção das autoridades, ainda que se tratando de detentas. 
Nos planos e nos projetos de estabelecimentos prisionais femininos havia previsão de seções especiais para abrigar as internas gestantes e aquelas que amamentavam. No plano de reformatório de mulheres da Bahia, estavam previstas celas especiais para que as mães pudessem amamentar seus filhos durante os primeiros meses do nascimento (APB, 1941b, p. 325). Na Penitenciária de Mulheres de Bangu, havia, segundo relatos de 1946, uma secção para mães com filhos pequenos, bem como um espaço para visitas dos filhos maiores, de modo que estes pudessem "brincar" com elas "sem se aperceberem da sua vida de presidiárias" (APB, 1946, p.47).

De acordo com Lemos Britto, na exposição de motivos do Regimento dos estabelecimentos de Bangu, em relação aos filhos das sentenciadas seguiu-se a tendência do Código Rocco, Código Penal da Itália Fascista, promulgado em 1930, que garantia cuidados especiais às mulheres presas grávidas e permitia a permanência dos filhos no cárcere, junto às mães, até os dois anos de idade. Isso garantiria o cuidado durante os primeiros anos de vida e evitaria que a criança crescesse no ambiente carcerário. Em sua palestra As Mulheres Presas e seu Tratamento Penitenciário, Lemos Britto aponta esse cuidado como fator importante na edificação do cárcere para mulheres, ressaltando que nos cárceres femininos de países como Estados Unidos, Tchecoslováquia, França, Itália e outros, havia a previsão de que as crianças permanecessem junto às mães encarceradas durante dois ou três anos (1943, pp. 22 e 23). Em A Estrela, uma reportagem sobre a Penitenciária de Mulheres de Bangu assim mencionava o espaço destinado às mães presas:

numa parte lateral, com acesso direto ao pátio dos esportes, está sendo construído um pequeno pavilhão destinado às que tem filhos. É mais um detalhe curioso: separar as mamães e dedicar aos seus filhos uma assistência adequada com outras crianças, proporcionando-lhes um convívio compatível com a idade, dentro das possibilidades, capaz de preservá-los de um pior início. Há na penitenciária algumas crianças entre elas um menino que é cego. Observamos o carinho e a ternura com que são tratadas aquelas infortunadas crianças; todos procuram dar-lhes o aconchego de um lar que lhes falta (AE, junho de 1951, p.9). 
Não era sem resistências que o Conselho Penitenciário propunha práticas de humanização da pena. As propostas de garantir à gestante atendimento hospitalar e acompanhamento ao longo da gestação, por exemplo, eram amplamente criticadas. A resposta dada por Lemos Britto à crítica recebida pelo Conselho Penitenciário de que garantir às mulheres gestantes presas cuidados especiais era desrespeitar as mulheres honestas pobres, que pouco acesso tinham aos cuidados médicos pré-natais ilustra quais os valores principais que estavam em jogo quando se pretendia assegurar à presidiária gestante acesso à saúde e cuidados básicos. De acordo com o texto da exposição de motivos, “(...) quando o Estado age em tal sentido, não está esquecendo as outras mães pobres, nem se preocupando em demasia com as criminosas; está assim amparando a maternidade e defendendo o capital humano que é a criança, por meio do qual renovam gerações" (APB, 1942d, p. 40). A maternidade e a criança eram os bens principais salvaguardados pela medida, que era vista como um "imperativo de civilização e cultura" que

(...) manda assistir convenientemente a maternidade e a infância, mormente a desvalida, e nenhuma, senhor Ministro, mais desvalida que a que nasce num cárcere ou nele suga o leite materno. Cumpre, ainda, providenciar para que as mulheres grávidas não tenham os filhos no próprio estabelecimento penal, salvo caso de força maior, quando não seja possível transferir a internada para um estabelecimento hospitalar ou maternidade, com as devidas cautelas. Esta providência tem por fim impedir que por toda a vida o nascido no cárcere leve na fonte este gilvaz de opróbrio e humilhação, que poderá influir decisivamente em seu futuro (APB, 1942d, p.42).

A maternidade era protegida por um discurso estatal, que atribuía à família o status de célula social fundamental. Menos o discurso biológico da degenerescência e mais a perspectiva sociológica de que era o meio o responsável pela formação do caráter compunha as fundamentações daqueles que eram favoráveis à proteção da maternidade das detentas. A mulher, apesar de criminosa, tinha a possibilidade 
de ser mãe, potência que poderia ser salvadora da mulher em situação de marginalidade, uma vez que possivelmente a maternidade despertaria sentimentos puros, porém adormecidos nas criminosas. De acordo com Lemos Britto:

não é à sentenciada que dispensamos tratamento especial, é a alguma cousa que, ainda se tratando de criminosas, não perde a sua beleza e santidade, a maternidade fecunda e criadora; é, ainda à infância inocente, que não é culpada e não pode ser responsável pelos descaminhos daquelas cujo ventre as gerou (LEMOS BRITTO, 1943, p. 23).

A construção da Nação passava pelo ventre materno e, por mais impura que fosse a mulher, era na garantia de uma gestação saudável desenvolvida em ambiente são que o Estado deveria investir para que crianças crescessem sadias. Segundo texto publicado nos Arquivos:

os filhos das sentenciadas são também filhos dos homens honestos e bons, e, quando não fossem, seria iníquo punir nos natos, ou mesmo nos que vivem ainda no ventre materno, a culpa dos pais. A assistência social no Brasil, estabelecida em bases amplas e humanas pelo presidente Getúlio Vargas, não comporta exceções para os filhos de mulheres criminosas, que deverão voltar amanhã à sociedade como elementos sãos e fatores apreciáveis da ordem que preside ao seu desenvolvimento" (APB, 1942d, p.40).

O lado de dentro foi pensado e planejado em relação ao lado de fora. O projeto de um cárcere ressocializador pressupunha a dicotomia entre o interno e o externo, de modo a permitir que o primeiro fosse um treinamento para o "bem viver" no segundo. Nos esboços e práticas dos cárceres femininos em seus primeiros tempos é possível visualizar amostras de expectativas sociais voltadas ás mulheres no período, bem como dos espaços que deveriam ocupar. Voltado a mulheres reais, o cárcere ideal precisava adequar-se ao cotidiano prisional, repleto de dissonâncias e ambiguidades não colocadas no papel. 


\section{CONSIDERAÇÕES FINAIS}

\section{CORPOS E ALMAS DAS DETENTAS À LUZ DE ALGUNS TEÓRICOS CLÁSSICOS}

Por tudo o que foi apresentado, uma leitura possível do cotidiano das detentas administradas pelas Irmãs do Bom Pastor d’Angers, e das próprias Irmãs, é a de que seu dia-a-dia era composto por lições e exercícios voltados para aniquilar e anestesiar tudo aquilo que fugisse do ideal de padrão feminino hegemônico, oficializado nas décadas de 1940 e 1950.

É possível analisar o trabalho das Irmãs sobre o corpo e a alma das detentas utilizando elementos apontados por Michel Foucault como característicos de uma sociedade disciplinar e do papel desempenhado pelo cárcere moderno na produção de delinquências. Igualmente, os ensinamentos do psicólogo Erving Goffman, em sua obra Manicômios, Prisóes e Conventos, na qual analisa a situação dos internos em "instituições totais", principalmente em hospitais para doentes mentais nos Estados Unidos, são úteis para compreender as tentativas de uniformização e padronização das internas postas em prática pelas Irmãs. Já a análise feita por 
Marcel Mauss, no início do século XX, em As Técnicas do Corpo, é igualmente útil para refletir sobre as intervenções morais nos corpos das detentas, pois elementos considerados naturais às mulheres em geral, e às detentas em particular, mostram-se socialmente construídos de forma muito elaborada no interior de um complexo jogo sócio-institucional.

De acordo com Foucault, ao longo de toda a época clássica houve uma descoberta do corpo como objeto e, principalmente, como alvo do poder. O corpo economicamente útil tinha também uma utilidade política. A utilização desse corpo-objeto levaria a punição simples a ser substituída por uma punição politica e economicamente mais viável: a prisão disciplinar. Para Foucault, a "sociedade disciplinar", característica das sociedades modernas, se pauta na normalização de condutas. Trata-se de uma mecânica de poder destinada a criar mecanismos de controle voltados para o adestramento e a disciplina. A norma faz-se presente operando a partir da normalização, da técnica e do controle presentes em todo o tecido social. Nesse contexto, pode-se dizer que a disciplina inaugura a "era da norma" que irá se aperfeiçoar a partir do século XVIII, quando "a forma geral de uma aparelhagem para tornar os indivíduos dóceis e úteis, através de um trabalho preciso sobre o seu corpo criou a instituição-prisão, antes que a lei a definisse como a pena por excelência" (FOUCAULT, 2004, p. 195).

Em Vigiar e Punir - história da violência nas prisóes, Foucault ressalta que, na sociedade disciplinar, o corpo, assim como em outros momentos da história dos castigos, também é interrogado, também confessa, e é encarcerado, mas, diferentemente de outros momentos, o corpo é disciplinado. Segundo o autor, a sociedade disciplinar inaugura um trabalho sobre um corpo que “(...) se manipula, se modela, se treina, que obedece, responde, se torna hábil ou cujas forças se multiplicam”. Nessa dinâmica disciplinar, o poder penetra nos corpos enfileirando-os, endireitando-os, mecanizando-os. São modelados pelo poder sendo a disciplina o grande segredo dessa modelagem. Marionete do poder, o corpo punido é colocado na "máquina da disciplina”. A prisão, como espaço de reprodução de mecanismos e relações sociais existentes extragrades, insere-se como instituição a serviço dessa sociedade. 
As marcas agora não são mais físicas e tatuadas no corpo, como nos tempos dos suplícios, mas impregnadas no comportamento. A disciplina é detalhista, sendo cada gesto, cada movimento, cada palavra, cada posição, cada articulação controlada por ela. A disciplina cronometra e o tempo é seu grande aliado. O corpo é condicionado a utilizar o tempo da melhor forma possível e o trabalho da disciplina na sociedade se dá em duas frentes principais: sobre o individuo e sobre o múltiplo. $\mathrm{O}$ corpo sozinho e o corpo como peça de uma grande máquina heterogênea são alvos, que têm como papel principal instruir o singular ligando-o ao múltiplo. $\mathrm{O}$ ser disciplinado é, ao mesmo tempo, uno e membro do todo, e é para esse todo que deve ser devolvido o indivíduo treinado na prisão. O poder disciplinar adestra e busca, por meio da "educação total", "impor uma nova forma ao indivíduo pervertido" (FOULCAULT, 2004, p. 199).

A vigilância hierárquica é a tática que liga, para Foucault, o individual ao múltiplo. Existe um papel definido a cada ator no teatro da ordem: os vigiados vigiam e os vigias são vigiados, formando assim uma grande teia de vigilância hierarquicamente articulada. Dessa forma, cada um exerce seu papel individual e ao mesmo tempo ligado ao outro. As sanções disciplinares têm como função normalizar, colocando aquilo que não está "normal" em seu devido lugar. A ordem é elemento essencial da disciplina e, para mantê-la, a sanção se faz necessária. $\mathrm{O}$ corpo passa, assim, por um constante processo de normalização. As falhas são sempre corrigidas com o maior detalhe e atenção para que a ordem e o "normal" prevaleçam. O castigo disciplinar tem como objetivo principal a redução dos desvios e consequentemente a normalização. $\mathrm{O}$ exame, por fim, é aliado da disciplina uma vez que representa um controle atento à manutenção do normal. Trata-se de vigilância que qualifica, classifica e pune. Examinar é exercer um poder constante sobre os corpos disciplinados, é exigir deles uma constante prova de sua disciplina. A disciplina pretende "docilizar" os corpos, ou seja, torná-los submissos, dóceis, pacíficos e doutrinados.

Para Foucault, há no Cárcere uma "recodificação da existência" que é organizada por meio do isolamento, do trabalho e da modulação da pena. $\mathrm{O}$ isolamento deve ser tanto em relação ao mundo exterior quanto dentro do próprio cárcere, 
de modo a separar os indivíduos e evitar quaisquer formas de agrupamentos, além de ser necessário para garantir a expiação da culpa e a vivência da solidão, capazes de ativar o remorso. Há na prisão, segundo o autor, a "individualização coercitiva, pela ruptura de qualquer relação que não seja controlada pelo poder ou ordenada de acordo com a hierarquia" (FOUCAULT, 2004, p. 199 a 201).

Já o trabalho é tido como elemento inerente ao cárcere, seja ele forçado, consensual ou tratado como um direito/dever. Sendo a função alegada do cárcere moderno a recuperação dos indivíduos para a vida em sociedade, a forma considerada privilegiada de ressocializá-lo é por meio daquilo que é valorizado socialmente: o trabalho. Trata-se de uma forma de "submissão individual e de seu ajustamento a um aparelho de produção", de modo a "recuperar o ladrão em operário dócil" (FOUCAULT, 2004, p. 204). O trabalho é assim considerado importante pelos "efeitos que toma na mecânica humana", pois,

é um princípio de ordem e de regularidade; pelas exigências que lhe são próprias veicula, de maneira insensível, as formas de um poder rigoroso; sujeita os corpos a movimentos regulares, impõe uma hierarquia e uma vigilância que serão ainda mais bem aceitas, e penetrarão ainda mais profundamente no comportamento dos condenados, por fazerem parte de sua lógica (...)(FOUCAULT, 2004, p. 203)

Ainda de acordo com Foucault, enquanto espaço de modulação da pena, a prisão visa à materialização da punição prevista na sentença. $\mathrm{O}$ indivíduo deve ser transformado no cárcere e não "apenas" punido, de modo que seja "efetiva a ação da prisão sobre os detentos" (FOUCAULT, 2004, p. 206). É no interior da instituição prisional que o poder punitivo é materializado, pois há um espaço de autonomia punitiva carcerária que vai além da sanção prescrita pelo juiz. Para colocar em prática as transformações nos indivíduos, o "aparelho carcerário" se utiliza de "três grandes esquemas": o político-moral do isolamento e da hierarquia; o modelo econômico da força aplicada a um trabalho obrigatório; e o modelo técnico-médico da cura e da normalização. "A cela, a oficina, o hospital." Esse cotidiano punitivo que decorre do 
jurídico, mas ultrapassa suas fronteiras é, para o autor, caracterizado pelo "penitenciário" (FOUCAULT, 2004, p. 208), sendo no interior da prisão que o infrator adquire o status de delinquente, "unidade biográfica, núcleo de 'periculosidade', representante de um tipo de anomalia" (FOUCAULT, 2004, p. 212).

Segundo Foucault há, desde o início do "cárcere moderno", “(...) sete máximas universais da boa 'condição penitenciária'”: I) a aposta na transformação do indivíduo encarcerado; II) o isolamento e/ou agrupamento dos detentos de acordo com características como idade, gravidade penal do ato e técnicas de correção; III) as penas e as nuances de sua prática cotidiana; IV) o investimento no trabalho prisional como elemento-chave na "transformação" do detento; V) investimento na educação do detento, como sendo um direito/dever deste; VI) administração do regime prisional exercida por pessoas com "capacidade moral e técnica de zelar pela boa formação dos indivíduos"; VII) prática de medidas de controle e assistência do detento dentro e fora do cárcere, garantindo a sua readaptação" (FOUCAULT, 2004, pp. 224 e 225). A prisão se edifica e se reforma norteada por essas máximas. Para Foucault, "palavra por palavra, de um século a outro, as mesmas proposições fundamentais se repetem. E são dadas a cada vez como a formulação enfim obtida, enfim aceita de uma reforma até então sempre fracassada" (FOUCAULT, 2004, p. 225). Tais baluartes das boas condições carcerárias realimentam as críticas às prisões, quando estas não colocam em prática aquilo que apregoam, bem como estimulam as reformas e a ilusão de que é possível atingir a instituição perfeita. Em uma complexa rede de justificações e reforços jurídicos, políticos e sociais, o sistema carcerário, de acordo com este pensador, "junta numa mesma figura discursos e arquitetos, regulamentos coercitivos e proposições científicas, efeitos sociais reais e utopias invencíveis, programas para corrigir a delinqüência e mecanismos que solidificam a delinqüência” (FOUCAULT, 2004, p. 225).

Retomando as propostas, os discursos e as configurações das primeiras instituições carcerárias femininas, é possível verificar muitos dos elementos apontados por Foucault em Vigiar e Punir. Na origem dos cárceres femininos brasileiros, havia uma clara preocupação de intervenção disciplinar nos corpos das internas, de modo 
a domesticá-los e a conter manifestações de corpos descontrolados e não regulamentados. É possível, com base no instrumental analítico desenvolvido por Foucault, identificar a ação da disciplina sobre aquelas mulheres que eram consideradas desviantes e dignas do trabalho de remodelação pessoal a ser praticado no cárcere. $\mathrm{O}$ investimento na docilização dos corpos é uma das mais claras funções alegadas para o aprisionamento feminino que, como já apontado, deveria devolver à sociedade mulheres domesticadas e domésticas, cristianizadas, moldadas nas funções socialmente prescritas como femininas.

Nesse sentido, também é possível, considerando o mecanismo prisional de produção de delinquentes apontado por Foucault, afirmar que a prisão feminina surge como espaço que ratifica a figura da desviante de um modelo socialmente aceito e recria o estereótipo do modelo hegemônico como positivo. Além disso, permite a criação de "tipos delinquentes" com base nas classificações internas do sistema. $\mathrm{Ou}$ seja, ao criarem o escalonamento das criminosas e se preocuparem com a promiscuidade entre os diferentes tipos de delinquentes, os penitenciaristas e operadores do direito justificavam os mecanismos de individualização da pena e de categorização das detentas segundo critérios como crimes cometidos e classes sociais, corroborando as classificações e rotulações que "geravam delinquências".

Ainda de acordo com Foucault, as penalidades gerenciam as ilegalidades. No interior de uma lógica de dominação, as condutas consideradas crimes são estrategicamente definidas e as leis são feitas por uma classe e voltadas para outra, enquanto os tribunais são organizados de modo a combater uma desordem que tem como parâmetro uma ordem também estrategicamente moldada. Nesse sentido, pode-se dizer que a criminalidade feminina à época da criação das primeiras unidades prisionais para mulheres era pautada por paradigmas de "dever ser" femininos, sendo em especial as modalidades de ilegalidades gerenciadas aquelas que poderiam ser atribuídas às que rompiam com esses modelos. As mulheres que faziam jus à conversão, pelo sistema, em "unidades biográficas" delinquenciais eram as que não correspondiam ao padrão feminino que privilegiava o recato, a maternidade, o casamento, a ordem e a feminilidade comedida. 
A crença que ronda o imaginário punitivo moderno, de que os réus e acusados, “(...) por falta de recursos e educação não sabem permanecer nos limites da probidade legal" é apontada por Foucault, em Vigiar e Punir (FOUCAULT, 2004, p. 229). Interessante notar como no período analisado há um reforço do estereótipo de "classes perigosas" e uma associação imediata entre a falta de educação e a criminalidade, algo que, inclusive, se confirma nos dados estatísticos analisados. No entanto, a inversão de perspectivas permite uma análise para além da associação entre dados de criminalidade e determinado grupo social, uma vez que, antes de haver uma "classe perigosa", há um público-alvo da justiça criminal que é aquele rotulado como "classe perigosa". A criminalização da pobreza, das classes trabalhadoras e daqueles que não se encaixavam nos formatos socialmente prescritos reflete a seleção feita pelo sistema de justiça que elege determinado grupo como agente criminógeno e constrói todo um aparato punitivo capaz de isolá-lo do seio social, bem como de rotulá-lo como delinquente, acionando mecanismos de controle e disciplina voltados para sua domesticação.

Como é possível notar, a contribuição foucaultiana para a análise proposta é de suma importância, pois permite trazer à tona sutilezas que denunciam dinâmicas de poder e controle escamoteadas no discurso de humanização da pena e da função do cárcere. A partir de uma metodologia específica - a genealogia - e de uma densa pesquisa histórica, Foucault desnaturaliza discursos sobre a prisão e a punição, desconstruindo-os para reconstruí-los enquanto mecanismos historicamente edificados. O retorno no tempo permite o apontamento de permanências de dispositivos punitivos e de controle social que, sob diferentes roupagens, voltam a ocupar os discursos e as práticas. No caso específico da análise das origens dos presídios femininos no Brasil, a opção por apontar nos discursos de penitenciaristas e outros personagens do período as funções desejadas do cárcere feminino, os contornos das figuras desviantes e as bases dos estabelecimentos prisionais para mulheres foi influenciada pela análise foucaultiana. Retomar de que maneira aqueles que pensaram o cárcere feminino o propuseram, buscando em seus discursos e posicionamentos elementos que apontam estratégias de como deveria ser exercido o controle sobre as mulheres 
"delinquentes", foi tarefa certamente inspirada nesses pontos ressaltados do trabalho de Michel Foucault.

É importante, igualmente, apontar os possíveis paralelos entre a pesquisa aqui apresentada e o trabalho feito pelo psicólogo Erving Goffman. Resultado de uma pesquisa de campo em um hospital psiquiátrico, feita na década de 1950, e em diálogo com uma ampla bibliografia sobre os temas tratados, Goffman inovou ao refletir sobre características comuns a instituições que têm como um de seus objetivos manifestos o isolamento para a cura e a recuperação. Como "instituição total", Goffman entende as instituições que são em grande parte fechadas ao mundo externo, que restringem a circulação daqueles que nela habitam aos seus próprios espaços, inviabilizando, por diferentes razões, o trânsito e o contato com a sociedade mais ampla e com as demais instituições. As "instituições totais" da sociedade que analisa (no caso a sociedade ocidental da década de 1950) podem ser agrupadas de cinco formas: aquelas destinadas a cuidar dos considerados incapazes (idosos, crianças, pessoas com problemas físicos etc.); as voltadas para o cuidado de incapazes considerados socialmente perigosos (doentes mentais, portadores de doenças contagiosas e outros); as que têm como função proteger a comunidade de ameaças intencionais, sendo o bem-estar daqueles que são internados menos importante que o da comunidade protegida (prisões, campos de guerra, campos de concentração, dentre outros); aquelas voltadas para a realização de trabalhos (quartéis, campos de trabalho etc.); e, por fim, os espaços destinados ao afastamento do mundo, como é o caso dos retiros religiosos, conventos e outros.

Apesar de enumerar um rol de características comuns a estas instituições, o autor alerta para o fato de nem todas apresentarem o total de características enumeradas, mas de reunirem, em si, uma série de atributos que, quando combinados, podem aproximá-las de "instituições totais". Uma das características centrais dessas é que todas as atividades diárias são realizadas em um mesmo local, ou seja, dorme-se, trabalha-se, alimenta-se etc. no mesmo espaço, não havendo deslocamentos para fora da instituição. Em geral, tais atividades são realizadas em conjunto, reunindo todos os internados para o cumprimento de uma mesma função. As atividades cos- 
tumam ser previamente organizadas e cronometradas, estando sua realização e duração constantemente sob vigilância.

Para Goffman, há nas "instituições totais" dois grupos principais de pessoas a serem observados: o grupo das que são controlados e o grupo das que controlam. Do primeiro fazem parte todos aqueles que pertencem ao público-alvo da instituição, ou seja, os internos. Já do segundo participam aqueles cuja função é administrar, em diferentes instâncias internas, as atividades cotidianas da instituição. São eles a quem o autor chama de "equipe supervisora" ou "equipe dirigente". Enquanto os internados residem na instituição, os membros da equipe dirigente trabalham no local, podendo transitar por outros espaços para além do circuito institucional.

Em relação aos internados, o autor desenvolve uma análise detalhada da forma como a "instituição total" opera de maneira a alterar as concepções do "Eu" previamente formadas pelos indivíduos que nela ingressarem. São inúmeras as mudanças geradas pelas instituições nas crenças que cada interno tem sobre si. Tais mudanças são chamadas pelo autor de "mutilações do Eu", e têm início na separação do internado de tudo o que diz respeito à vida que levava no mundo externo e ao que não diz respeito à instituição, gerando a perda dos papéis habituais que realizava fora do espaço institucional. Nos "processos de admissão", que ocorrem nos momentos iniciais da internação, há, em geral, restrições à expressão das identidades do internos. Eles se tornam números (pesos, medidas, matrículas institucionais etc.), bem como são destituídos de tudo aquilo que os diferenciava dos demais internados (cabelo, roupas, perfumes, assessórios, dentre outros), ocorrendo uma padronização da aparência (mesmos cortes de cabelo, mesmas roupas, mesmas rotinas).

A privacidade é um luxo ao qual os internados não têm acesso. Tudo é realizado de maneira coletiva e a exposição constante é marca das "instituições totais". Busca-se, a cada dia, a dissolução mais completa do "Eu", ocorrendo os processos chamados por Goffman de "ataques ao Eu", "mortificação de sentimentos", "mortificação do Eu", "mutilação do Eu", dentre outros. Todos esses processos representam formas de institucionalizar cada vez mais aquele que está internado na instituição, levando a uma completa desorganização de suas representações. Concomitantemente a esses 
processos, ocorrem, de maneira formal e informal, a informação aos novatos daquilo que Goffman chama de "sistema de privilégios", que seria responsável pela reorganização pessoal do internado, agora segundo as racionalidades do local. Tal sistema é composto pelas regras da casa, responsáveis pela especificação da rotina do internado; por um reduzido, mas presente, sistema de bonificação, que premia as obediências e bons-comportamentos; e por uma estrutura de castigos e punições caso as regras não sejam seguidas ou se houver qualquer tipo de manifestação não elencada como permitida.

Por fim, Goffman não deixa de mencionar algumas variabilidades de uma "instituição total" para outra. O paradoxo entre permeabilidade e impermeabilidade das "instituições totais" está presente na discussão, uma vez que, dependendo de suas finalidades, algumas podem permitir mais ou menos fluxos entre suas fronteiras. Há também variabilidades em relação à forma de entrada na instituição, já que, enquanto em umas, como é o caso de freiras e monges, ingressar na instituição é, em geral, uma escolha, em outras se entra de maneira obrigatória, como no caso dos prisioneiros condenados por algum crime, dos doentes mentais internados por parentes, dos presos em campos de concentração.

Os apontamentos de Goffman sobre as "instituições totais" permitem alguns diálogos com o presente trabalho, em especial em relação às "mutilações do Eu" e aos processos de uniformização das internas, bem como possibilita reflexões acerca da dicotomia entre internadas e grupo dirigente, uma vez que, no caso específico dos presídios femininos, essas categorias se confundem, pois há duas "instituições totais" no interior de uma única instituição: um convento e uma prisão. É também possível identificar paralelos com os "sistemas de privilégios" e "bonificações" apresentados pelo autor, pois havia a previsão, em algumas normativas prisionais e em discursos sobre os presídios femininos, de sistemas de bonificações para aquelas que apresentassem comportamentos exemplares.

Ao colocar controladoras e controladas em duas categorias, é possível, em um primeiro momento, supor que Goffman deixa de lado a perspectiva relacional e trabalha apenas com um "dever ser institucional" que não leva em consideração as 
relações cotidianas como elas de fato se estabelecem. Teoricamente, a relação entre as Irmãs vigilantes e as internas vigiadas deveria assumir essa dicotomia. No entanto, dois elementos merecem destaque quando em pauta as relações de poder estabelecidas no cárcere feminino e a análise do autor.

O primeiro deles é que a dicotomia dominante/dominado, controlador/ controlado não deixa de lado os potenciais de interação entre as partes e as negociações cotidianas dentro de um estabelecimento fechado. Isso porque Goffman preocupou-se, ao longo de sua produção acadêmica, com as maneiras como cada um age em diferentes situações cotidianas, sendo tais "definições de situação" fundamentais para compreender os comportamentos humanos. A forma como as pessoas orientam suas ações no cotidiano, de modo a se adequarem a cada uma das situações vivenciadas, não parte, segundo Goffman, de escolhas individuais, mas são definidas por "situações de poder" instauradas no momento, o que flexibiliza categorias que, a priori, parecem estanques. Quem, em determinada situação, tem mais poder é quem tem legitimidade para defini-la. Apesar do presente trabalho não ter mergulhado no cotidiano prisional, mas ter se detido, principalmente, nos modelos institucionais pretendidos para o aprisionamento feminino - o que não permite uma análise aprofundada das relações pessoais cotidianas estabelecidas intramuros -, pode-se afirmar que certamente havia arranjos situacionais entre as Irmãs e as detentas, das Irmãs entre si, das detentas entre si e destas em relação à administração geral penitenciária, não sendo possível ignorar o potencial de agência dos sujeitos nessas múltiplas relações, em que, provavelmente, eram rompidas as rígidas fronteiras que as dicotomias pressupõem.

O segundo ponto, que ressalta uma particularidade das instituições prisionais femininas em seus primeiros anos, é o de que, pensando no modelo de "instituições totais" sugerido por Goffman, há, no cárcere feminino duas "instituições totais" simultâneas, que são o convento e a prisão, conforme já apontado, sendo a primeira um espaço originalmente de refúgio meditativo e a segunda voltada à segregação de indivíduos considerados perigosos e desviantes. Justamente por ambas serem "instituições totais", possuem características comuns, como reunir no mesmo local mo- 
radia, trabalho e alimentação; a pouca permeabilidade com o mundo externo (tendo evidentemente, neste caso, as Irmãs um contato maior que as detentas); o rígido controle do tempo; e os processos de "mortificação do Eu" vividos pelas Irmãs e pelas internas ${ }^{90}$. A anulação dos "excessos" de feminilidade, as regras de recato e discrição, o combate a qualquer traço de sexualidade aparente e o uso de uniformes era comum tanto às detentas quanto às Irmãs. Internas de uma "instituição total", as Irmãs administram as detentas, igualmente internas. Diversas finalidades simultâneas conviviam em um espaço onde as expectativas do aprisionamento feminino, por vezes, se confundiam com o objetivo meditativo da reclusão monástica e com o objetivo ressocializador da expiação do pecado de haver cometidos crimes ${ }^{91}$. Ao mesmo tempo em que as finalidades de ambas as instituições, em certa medida, se confundiam, um cuidado para evitar a contaminação de uma instituição pela outra era tomado, pois a santidade atribuída às Irmãs se contrapunha ao desvio representado pelas detentas. A complexa relação entre essas "instituições totais", característica das origens das penitenciárias femininas brasileiras, denota as ambiguidades existentes nesses espaços onde transgressões eram consideradas antes pecados, e o arrependimento e submissão a Deus confundiam-se com as funções da pena.

Vale ressaltar ainda, em relação aos processos de "mutilação do Eu", que esses são proporcionais aos "sistemas de bonificação", pois quanto mais padronizada nos moldes previstos pela instituição, mais bonificada deveria ser a interna. No caso dos presídios femininos, e isto pode ser notado no Guia das Internas de Bangu, quanto mais adequadas a um modelo de recato, quanto menos escandalosas e mais dóceis e submissas, melhor seria considerado o comportamento das detentas ${ }^{92}$. A aniquila-

90 As fotografias de identificação criminal apresentadas no segundo capítulo deste trabalho retratam o processo de uniformização sofrido pelas mulheres a partir do momento em que ingressam na prisão. Já as imagens das Irmãs apresentadas no quarto capítulo mostram a padronização provocada pelo hábito da Congregação.

91 Na Exposição de Motivos do Anteprojeto do Regimento da Penitenciária de Bangu, Lemos Britto, ao tratar das penitenciárias femininas francesas que, em sua maioria, tinha administração religiosa, fala de uma Irmã francesa que recebeu uma medalha penitenciária, tendo esta permanecido no estabelecimento 50 anos sem sair sequer um dia.

92 Havia, no Guia, a previsão de um sistema de bonificação, segundo o qual as internas receberiam estrelas de diferentes cores (possivelmente broches de pano que deveriam ser colocados nos uniformes), os quais representavam comportamento neutro, bom e ótimo. 
ção de componentes negativos atribuídos às mulheres era, inclusive, uma das principais funções do encarceramento feminino.

Por fim, mas não menos importante, cabe apontar a contribuição da análise de Marcel Mauss sobre as técnicas do corpo para o exame das práticas de controle corporal realizadas pelas Irmãs no interior dos cárceres. Apesar de não ter tratado especificamente da temática prisional e da educação corporal nesse espaço os apontamentos do autor possibilitam refletir sobre a educação corporal das mulheres presas e, também, das próprias Irmãs.

Mauss ressalta que as técnicas corporais consideradas naturais, como o andar, o comer, o nadar e o dormir, são socialmente estabelecidas, o que faz com que difiram de uma sociedade a outra. Sua afirmação de que não existe uma forma natural no adulto traduz a não essencialização das técnicas corporais. Há, para o autor, uma "natureza social do habitus", sendo este uma variável cultural (MAUSS, 2003, p. 404). O corpo é moldado e serve como molde, sendo “(...) o primeiro e mais natural instrumento do homem. Ou, mais exatamente, sem falar de instrumento: o primeiro e o mais natural objeto técnico, e ao mesmo tempo meio técnico, do homem, é seu corpo" (MAUSS, 2003, p. 404). Há uma educação, consciente ou não, voltada para a maneira como o corpo é utilizado. Tais técnicas, segundo o autor, variam de acordo com o sexo, a idade e seu rendimento. Os corpos são adestrados de diferentes maneiras, levando em consideração elementos naturais, morais, físicos e sociais, sendo as técnicas culturalmente inseridas.

Existem, para Mauss, "normas humanas de adestramento humano" e, por meio do ensinamento, essas técnicas são transmitidas, sendo "uma das razões pelas quais essas séries podem ser montadas mais facilmente no indivíduo é que elas são montadas pela autoridade social e para ela" (MAUSS, 2003, p. 420). O corpo, que é socialmente adaptado para o seu uso, sofre intervenções propiciadas por diferentes ordens.

Analisando o caso específico dos presídios femininos, é possível verificar a presença, nessas instituições, de mecanismos de adestramento do corpo das detentas, com base em estereótipos de mulher socialmente bem comportada. Todas as normas 
de comportamento - a maneira de se portar no refeitório, de se vestir, de pentear-se e falar - indicam adestramentos pautados em um "dever ser" feminino, que preza pelos "bons modos" e pela decência que simbolizam a "mulher honesta". Os condicionamentos trabalhavam os "excessos" de modo a equilibrar características extremadas, para que as detentas não fossem nem muito femininas, nem pouco femininas; nem escandalosas, nem apáticas; nem muito vaidosas, nem desarrumadas.

\section{CONCLUSÕES}

Ao refletir, em Tristes Trópicos, sobre a postura do etnógrafo perante sua própria sociedade e as sociedades pesquisadas, Lévi-Strauss ressalta a necessidade de se compreender o contexto e a estrutura nos quais determinadas práticas se baseiam, levando em consideração a ausência de sociedades com virtudes absolutas e sem defeitos. Ressalta que conhecer melhor outras sociedades possibilita ao etnógrafo distanciar-se da sua - única da qual não está liberto - para que então possa observá-la, criticá-la e transformá-la. Para que consiga se libertar, o pesquisador deve observar outros costumes e conseguir extrair deles princípios da vida social capazes de auxiliar em reformas dos princípios de seu próprio agrupamento. Esse exercício do olhar liberto, de fora para dentro, capaz de perceber que nenhuma sociedade é inteiramente boa ou má, mas estruturada de maneira peculiar, é proposto pelo autor como forma de refletir o aprendizado etnográfico em benefício da análise da sua própria sociedade.

Para exemplificar as diferentes formas de olhar quando se parte de referenciais diversos, o autor propõe uma reflexão acerca das práticas penitenciárias e judiciárias ocidentais, contrapondo o costume antropofágico de determinadas sociedades ao costume antropoêmico do encarceramento ocidental. Enquanto sociedades que praticam a antropofagia absorvem determinados indivíduos dotados de forças intensas como forma de neutralizá-las, na sociedade ocidental há um investimento na exclusão do indivíduo desviante do seio social, prática a qual Lévi-Strauss chamou de antropoemia, que significa "vomitar Homens". A antropoemia - o verter, o expulsar 
-, seria, nesse sentido, o oposto da antropofagia - a absorção, a digestão. Por isso, Lévi-Strauss afirma que "o cúmulo do absurdo é a nossa maneira de tratar ao mesmo tempo o culpado como uma criança, o que nos autoriza a puni-lo, e como um adulto, a fim de lhe recusar o consolo; e acreditar que realizamos um grande progresso espiritual porque preferimos mutilar física e moralmente alguns de nossos semelhantes, ao invés de consumi-los" (LÉVI-STRAUSS, 1996, p. 367). Essa reflexão presente em Tristes Trópicos, mais precisamente no capítulo denominado Um Copinho de Rum, no qual o autor arrisca como seria a possível indignação de alguns não ocidentais ao observarem costumes penitenciários do ocidente, pode ser emprestada para a análise do objeto da pesquisa que originou a presente dissertação. Isso porque a oposição entre antropofagia e antropoemia utilizada por Lévi-Strauss permite uma analogia com as propostas e práticas dos primeiros presídios de mulheres no país.

O "aproveitamento das habilidades das internas" e "absorção" de suas "potências femininas" como parte do plano de recuperação moral pelo trabalho e pelo desenvolvimento de "sentimentos" próprios da mulher compunha a proposta de cárcere feminino. A neutralização dos componentes criminosos por meio da "absorção" das mulheres desviantes pelas Irmãs, é a todo tempo ressaltada pelos penitenciaristas e mesmo pelas Irmãs, ao tratarem de sua missão. Seria tal projeto de recuperação moral e disciplinarização das detentas nos moldes de um "dever ser" feminino uma atitude antropofágica? Seria possível praticar a antropofagia em uma instituição essencialmente antropoêmica? Há um paradoxo entre a instituição e os seus projetos? Até que ponto as propostas carcerárias de reinserção social são antropofágicas para instituições que, a priori, são antropoêmicas?

As prisões, como todas as instituições, são produtos de variados processos sociais. Por isso, é possível estudá-las em diferentes áreas de conhecimento, bem como analisá-las a partir de pontos de vista diversos. As possíveis perspectivas sobre esse objeto de análise não se esgotam nos posicionamentos e relatos de seus idealiza- 
dores, dos internos, das internas, do corpo administrativo, de funcionários e funcionárias, visitantes, críticos e entusiastas, mas se multiplicam na medida em que cada um que compõe esse cenário se manifesta.

Estudar prisões, em especial a partir de documentos oficias, é uma opção de pesquisa que corre o risco de perder de vista diversos elementos que compõem o ambiente prisional, dificultando sua avaliação holística, mas qualquer perspectiva enfatizada implicaria deixar outras em segundo plano. Com a consciência de não se ter abrangido uma totalidade em relação aos atores envolvidos no surgimento das penitenciárias femininas no Brasil, tampouco no que diz respeito à bibliografia que poderia ser levantada e trabalhada, mas assumindo-se que foram analisados fragmentos de um cenário, buscou-se agrupar, neste trabalho, elementos que permitissem um aprofundamento analítico em partes desse contexto de criação dos primeiros estabelecimentos prisionais femininos no Brasil, privilegiando os discursos daqueles que estiveram envolvidos em sua criação, seja idealizando-os, administrando-os ou observando-os. Em torno destas instituições, ideais de funções penais conviviam com ideais de mulheres dignas de estarem no convívio social. As urgências de separar homens e mulheres e de garantir o cumprimento dos preceitos de humanização penitenciária em voga ligavam a instituição ideal - capaz de devolver à sociedade mulheres ideais - à instituição possível - que abrigava mulheres reais.

Dentre inúmeras possibilidades, privilegiou-se recuperar, por meio dos discursos e colocações de alguns de seus principais protagonistas, o processo de construção das instituições prisionais femininas, pela relevância sociológica e antropológica que tal análise possibilitaria. A maneira como estas - reprodutoras e produtoras de práticas punitivas, de controle e de ordenação social - foram idealizadas denuncia seus objetivos e funções dentro de um contexto social mais amplo, pautado pelo tênue limite entre normalidade e anormalidade, lícito e ilícito, correto e incorreto. As instituições prisionais embasadas em um discurso humanizado, como é o caso dos presídios femininos erguidos nas décadas de 1930 e 1940 no Brasil, pretendiam moldar pessoas, prescrevendo condutas ajustadas com base em padróes sociais que se buscava reproduzir. Os impactos esperados desses estabelecimentos na sociedade e 
naquelas que abrigavam permitem recompor estratégias de controle social mais amplas que as do próprio aprisionamento.

Moldar mulheres dentro de padrões de um "dever ser" socialmente prescrito era uma das principais apostas das instituições prisionais. Em tempos de expansão fabril e de aumento da participação feminina no mercado de trabalho, as mulheres eram, no cárcere, treinadas para funções do lar e realização de tarefas domésticas. Não era interessante para a estrutura familiar patriarcal que mulheres competissem no espaço público com os homens ou mesmo que se tornassem emancipadas. A organização da família, célula fundamental do moderno Estado brasileiro, passava pela mulher, e as que não sabiam sê-lo deveriam aprender. Além disso, acreditava-se que, com a mulher resguardada no lar, a potencialidade da criminalidade feminina diminuiria, uma vez que, como ressaltado no terceiro capítulo, alguns atribuíam o aumento do número de crimes cometidos por mulheres à sua maior participação na vida pública e ao fato de serem "naturalmente" propensas a certos comportamentos criminosos.

Todavia, a proposta de reeducação e recuperação moral das detentas para a sua reinserção na sociedade não possibilitou uma real transformação social, capaz de retirar essas mulheres das condições de subordinação e precariedade que as tornavam vulneráveis e expostas aos olhos da justiça criminal. Ter passado pelo sistema penal já era por si só fator estigmatizante em uma sociedade atenta aos desvios e aos detalhes. Além disso, a redenção divina não era garantia de que "andar em linha reta" traria recompensas extramuros, onde a fé possivelmente contrastaria com o cotidiano de demandas e dificuldades. Assim, é possível dizer que tanto no discurso quanto na prática, não havia propostas de enfrentamento da vulnerabilidade da condenada, mas investimentos em um plano de recuperação mais ideal que real. Em se tratando de uma sociedade na qual o casamento e a formação da família deveriam ser os principais objetivos das mulheres, treiná-las para a reinserção social era, em certa medida, capacitá-las para se adequarem a um modelo de vida ao qual não necessariamente se encaixavam e mesmo desejavam se encaixar. A família não significava, como não significa, garantia de conforto e segurança, podendo assumir versões tão ou mais opressoras que a própria prisão. 
Considerando que a grande maioria das mulheres presas e detidas pertencia a classes baixas, como demonstrado no segundo capítulo, sua recolocação na sociedade dificilmente permitiria transformações no modo de vida anterior à prisão, levando mais à reprodução de modos miseráveis de existência. Igualmente, na delimitação da escala de delinquentes proposta por Lombroso no final do século XIX e reproduzida pelos penitenciaristas brasileiros das décadas de 1930 e 1940, explicitada no terceiro capítulo, é possível visualizar a criminalização de mulheres pobres. A segregação social extramuros é reproduzida intramuros, o que faz do cárcere um espaço de continuidade da exclusão social e da estigmatização que ainda em liberdade enquadra pessoas como delinqüentes e desviantes - a proposta antropofágica se depara com a prática e a realidade antropoêmica.

Na base dos cárceres femininos, a Antropologia Criminal e o Direito Penal Clássico, apesar de teoricamente antagônicos, conviviam. Enquanto a primeira ditava as classificações das criminosas auxiliando o processo de estigmatização de determinados "tipos" de mulheres, o segundo compunha o projeto de cárcere feminino como espaço de expiação da culpa e de recuperação moral. Além disso, a pena individualizada, na medida do crime cometido, era prescrita para a cura da desviante e, por mais que o investimento fosse, antes, uma cura de ordem moral, o corpo e os desvios físicos e psíquicos não eram deixados de lado, o que evidencia mais um encontro dessas propostas criminológicas. A noção de degeneração atribuída a alguns tipos de delinquentes coexistia com a possibilidade de recomposição do seu caráter e sua reeducação para a vida em sociedade.

A presença, entre os penitenciaristas, de juristas que estabeleciam diálogo com as modernas práticas e teorias penitenciárias, justifica as delineações das instituições prisionais femininas baseadas na humanização penitenciária e nas propostas de ressocialização e reeducação das internas, anunciadas nos congressos, nos artigos e em debates sobre o tema. No entanto, o fato de uma Irmandade ter sido contratada para assumir a administração desses estabelecimentos embaralhou as delimitações teoricamente tão claras entre as escolas criminológicas, uma vez que o trabalho das Irmãs com as detentas era baseado em métodos religiosos praticados pela Con- 
gregação na cura moral das "desvalidas" e não nos métodos científicos presentes no universo jurídico e médico. Mais uma vez, o modelo idealizado se choca com a prática possível. As Irmãs, oriundas de uma Congregação com mais de um século de trabalho com mulheres socialmente vulneráveis, eram as responsáveis pelo cotidiano carcerário e, apesar de submetidas ao Estado e aos representantes da administração penitenciária, eram suas as palavras finais na organização do dia a dia penitenciário.

A urgência em separar homens de mulheres e diminuir o atraso dos cárceres nacionais rumo à superação do paradigma da prisão-masmorra explica as inúmeras adaptações que acompanharam a criação dos primeiros estabelecimentos prisionais femininos brasileiros. Além disso, o pequeno número de mulheres condenadas, em comparação à quantidade de homens sentenciados, justificava a pouca atenção dada ao aprisionamento feminino. A adaptação dos prédios, a escolha da opção mais prática e menos custosa para a administração, a falta de um projeto penitenciário claro - apesar do tema ser pauta antiga -, fez com que os presídios femininos nascessem no país de maneira improvisada. Mesmo tendo sido a Penitenciária de Mulheres de Bangu construída para tal fim, as constantes adaptações no prédio e os episódios de desentendimento entre as Irmãs e a direção geral evidenciam a pressa e os paradoxos que presidiram seu surgimento. Além disso, nenhuma penitenciária feminina tinha estrutura para lidar com o contingente de mulheres detidas por contravenções, o que acabava tornando a missão de separar homens e mulheres incompleta, uma vez que, mesmo nas cidades com estabelecimentos prisionais femininos, não era total a segregação entre os sexos.

A pesquisa ora apresentada possibilitou a recomposição de elementos importantes para a compreensão do fenômeno de criação das prisões femininas no país e de sua configuração inicial. Articulando temas como criminalidade feminina, práticas discursivas e punitivas, pensamento criminológico e comportamentos e expectativas sociais em relação aos sexos, buscou-se tecer o cenário no qual se ergueram 
essas primeiras instituições. Costurando os diversos estratos que compuseram o texto, a partir de uma abordagem antropológica em íntimo diálogo com o Direito e a História, tentou-se realizar arremates peculiares. Dentre eles, a não essencialização de categorias, mas sua consideração em conjunturas relacionais, como a concepção de "criminosa" em relação a modelos não desviantes e, por sua vez o cárcere feminino como referenciado em um "dever ser" e um "não ser" como pontos de partida. Aberta aos diálogos interdisciplinares e às experimentações nas fronteiras, a Antropologia permite compartilhar olhares múltiplos, tornando a recomposição de um fato passado não o mero recontar de uma história, mas uma de suas possíveis (re) leituras. 


\section{Epílogo}

\section{IMAGENS TECENDO O TEMPO}

\section{DA IMAGEM À SÉRIE}

Uma coleção de Fotos da Penitenciária Talavera Bruce, antigo complexo de Bangu, foi encontrada durante visita ao Centro de Estudos e Pesquisas da Escola de Gestão Penitenciária do Estado do Rio de Janeiro, em janeiro de 2011. Sobre ela não há informação de autoria, de época ou do contexto de sua encomenda $a^{93}$. O acervo é composto por aproximadamente 130 imagens que representam vistas internas e externas do espaço carcerário; tomadas de uma reforma em um pavilhão (possivelmente do Sanatório Penal); imagens de ambientes hospitalares, como leitos, salas de consulta e de exames, por vezes com médicos e pacientes também as compondo; imagens de espaços administrativos, com e sem funcionários; e, o mais importante, diversos registros do cotidiano da penitenciária feminina.

93 Nenhuma informação foi possível levantar junto à equipe do Centro de Estudos e Pesquisas da Escola de Gestão Penitenciária do Estado do Rio de Janeiro, que afirma não dispor de qualquer evidência que as documente. 
Pode-se afirmar que as tomadas foram feitas por fotógrafo profissional, o que é perceptível não apenas pelos enquadramentos, perspectivas, qualidade técnica e efeito visual cuidado nos contrastes de luz e sombra, mas também pela presença, em todas elas, de celulose protetor que indica a restrição do seu uso (lê-se "image" na tarja), prática comum em material fotográfico profissional. Percebe-se que não são imagens isoladas. Embora encerrem intenção e sequência ignorada, prestam-se hoje à maleabilidade de serem organizadas livremente pelo pesquisador, a efeito de ser um instrumento que compóe a narrativa pretendida para este ensaio final.

Selecionei 30 fotografias que pudessem dialogar com aspectos dos capítulos precedentes, montando-as em quatro séries temáticas. Uma vez que estas imagens são agrupadas e apresentadas em pequenas sequências visuais, elas podem assumir um sentido narrativo-ensaístico. Associadas, formam um todo coerente e se encadeiam como em um álbum de retratos. Com isso, evita-se empregá-las como clichês isolados para simples "ilustração". O agrupamento de fotografias umas às outras, à maneira de um mosaico, dá-lhes uma nova significação, atribuindo-lhes um interesse que não teriam em si mesmas ${ }^{94}$.

Este epílogo assume ares de uma "tentativa de gestão" dessa fonte visual encontrada por acaso. As seqüências ou grupos temáticos retomam algumas questões levantadas ao longo do trabalho, esboçando uma "escrita da imagem" "95 A série fotográfica, o encadeamento de cenas e sua adição faz sentido para "descrever um lu-

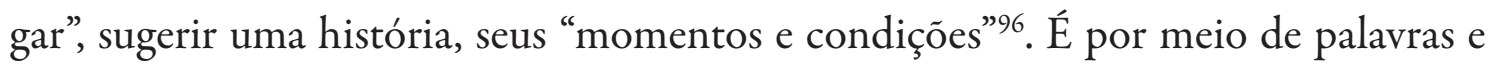
imagens que o cárcere feminino é aqui retratado em suas permanências e descontinuidades. Elemento de uma narrativa, a imagem é também narrativa, capaz de materializar visualmente o que a escrita descreve. Um lugar, um gesto, um rosto, uma ação, interiores, exteriores, um caminho...

94 Vale ressaltar que para escrever este ensaio tomei por base algumas leituras para compreender as acepções da noção de série e as possibilidades de construir seqüências narrativas com as fotografias encontradas. Entre elas estão: Olivier Lugon, "La série", em Le Style documentaire. D’Auguste Sander à Walker Evans. 1920-1945. Paris: Macula, 2001; e do mesmo autor "Séries, sequências e pranchas-contato", em Heliana Angotti-Salgueiro (ed.) $O$ olho fotográfico. Marcel Gautherot e seu tempo. São Paulo: FAAP, 2007.

95 Expressão de O. Lugon, 2001, p. 255.

96 Expressões de A. Rodtchenko, citadas por O. Lugon, 2007, p. 299. 
Os tempos mudavam, no devagar depressa dos tempos João Guimarães Rosa A Terceira Margem do Rio 

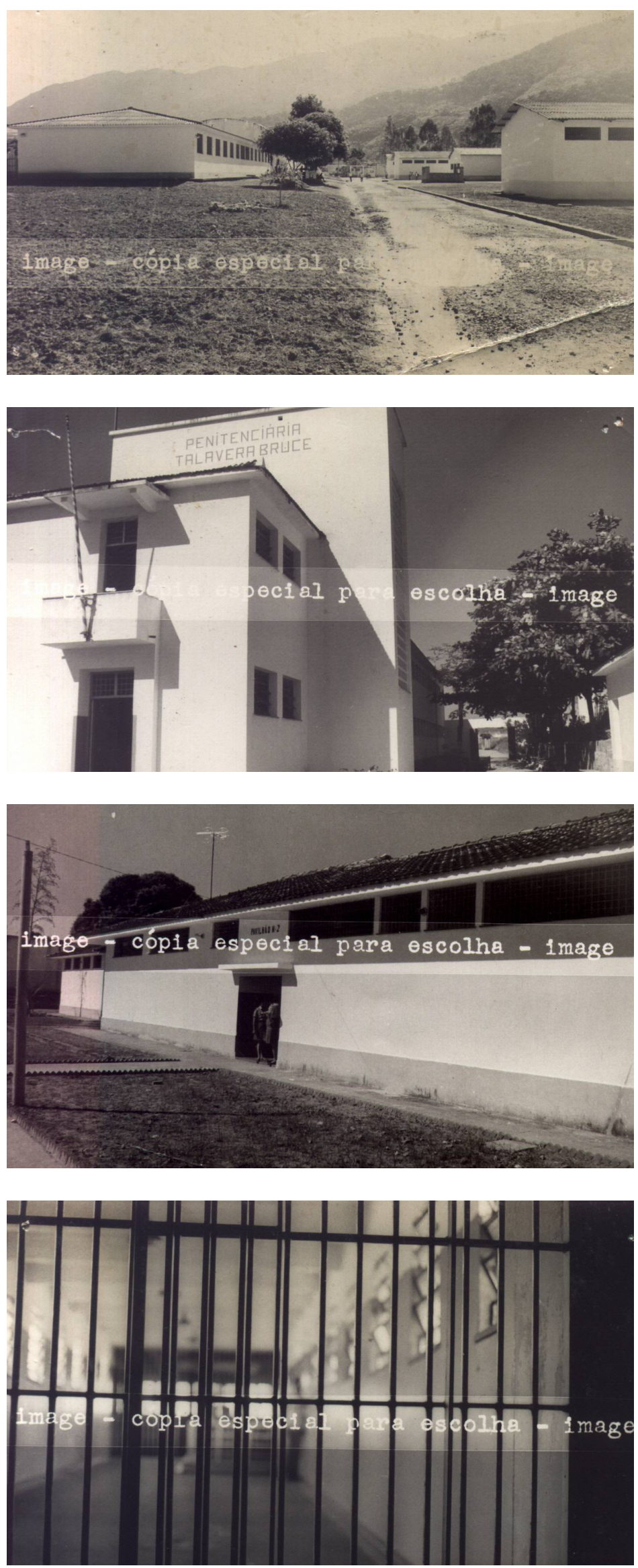


\section{ESPAÇO E CONFINAMENTO}
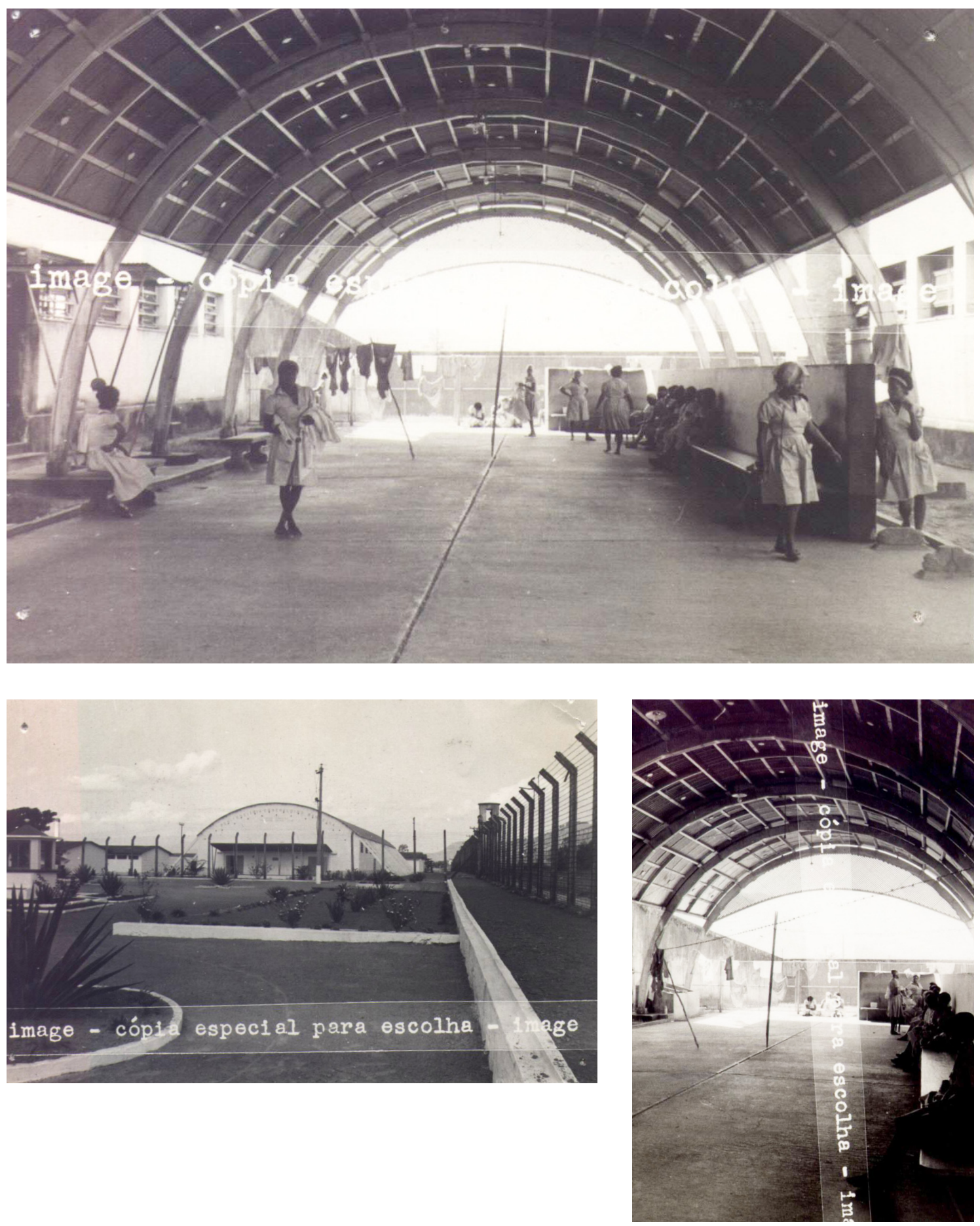
"A Penitenciária de Mulheres localiza-se numa depressão do terreno, com uma alameda arborizada com ficus, jardins, passeios - como que uma praça", ressaltava matéria publicada em A Estrela de 195197. Imagem e texto dialogam, apesar da distância temporal entre eles. A alameda com ficus continua intacta, mas os tempos, espaços e pessoas são outros. O local idealizado e as práticas nele experimentadas sofreram mudanças, e, apesar das continuidades, as lentes captam novos tempos. As Irmãs já não estavam mais lá oficialmente e o complexo de Bangu recebera o nome de Penitenciária Talavera Bruce, com administração laica e desvinculada da Penitenciária Central do Distrito Federal. O Sanatório Penal e o estabelecimento feminino continuavam no mesmo terreno, onde novas alas estavam em construção.

“... Transpusemos o portão principal; daí por diante somente mulheres existem. Novo jardim. Na frente de um pavilhão principal, um hall", descrevia o repórter d'A Estrela, no mesmo tom em que tratava do "lado de fora". Nas fotografias, porém, o externo contrasta com o interno: há uma distância entre eles que é retratada. As grades, omitidas pelo repórter ou inexistentes outrora, interrompem o bucólico ambiente externo, que parece isolado no tempo. Não há movimento. Não há sinais de vida urbana. Solitário na paisagem, o conjunto de casas largas e horizontalizadas não anuncia a sua função. $\mathrm{O}$ descampado do cenário expressa o quão apartado da cidade e do convívio social encontra-se o presídio, enquanto a grade delimita o mundo de dentro, onde, para aquelas que lá estão, o tempo é a medida da liberdade. Os contornos do prédio identificam o fora - plácido e organizado - e o dentro - habitado e desarranjado. Quando a lente capta o interior, para além da paisagem, passa a revelar peculiaridades do isolamento interno: é preciso adentrar a instituição para retratar seu cotidiano, suas internas, seus tempos.

$97 \quad$ AE, junho de 1951, pp. 3 a 5. 


\section{CICLO DO TRABALHO}
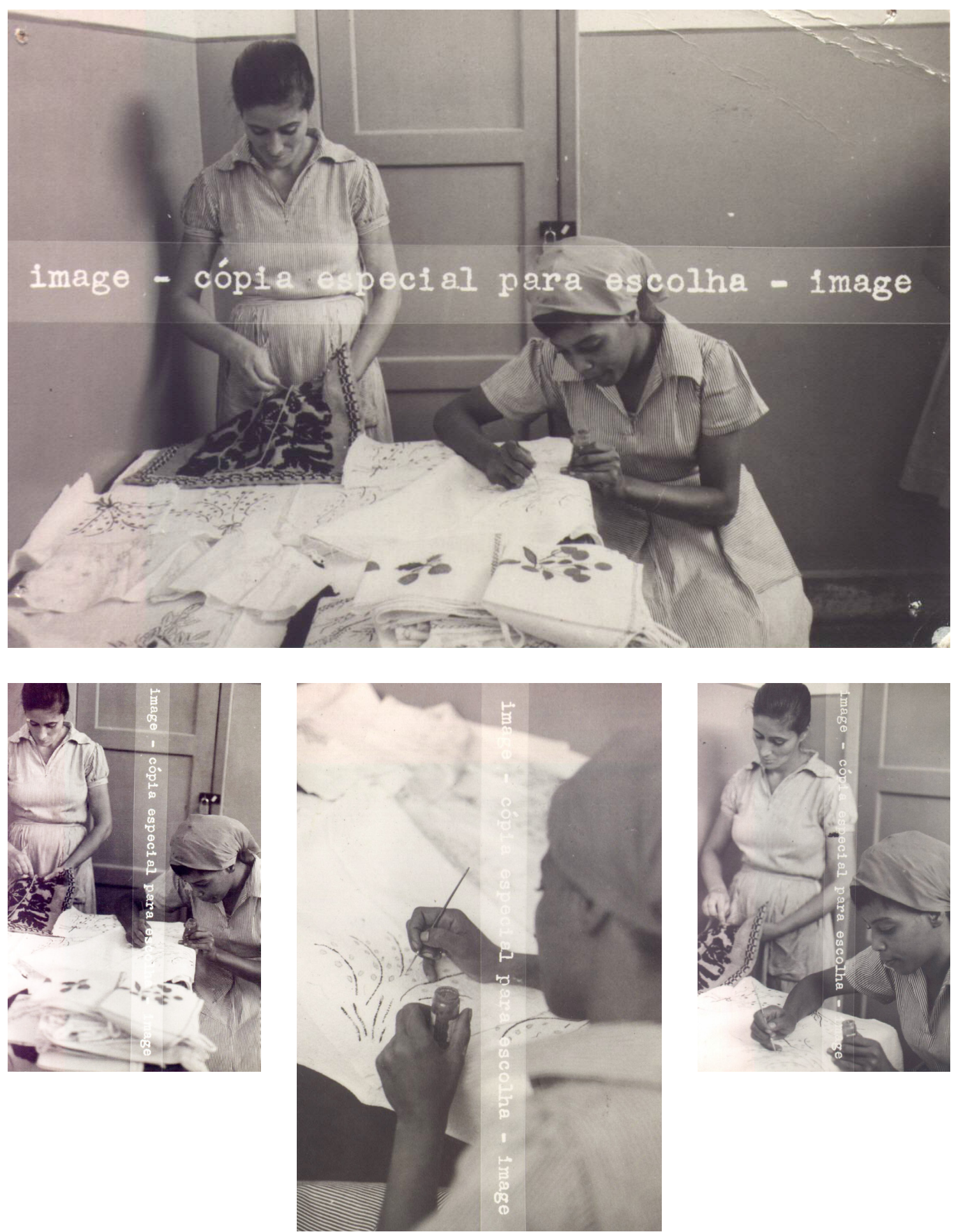

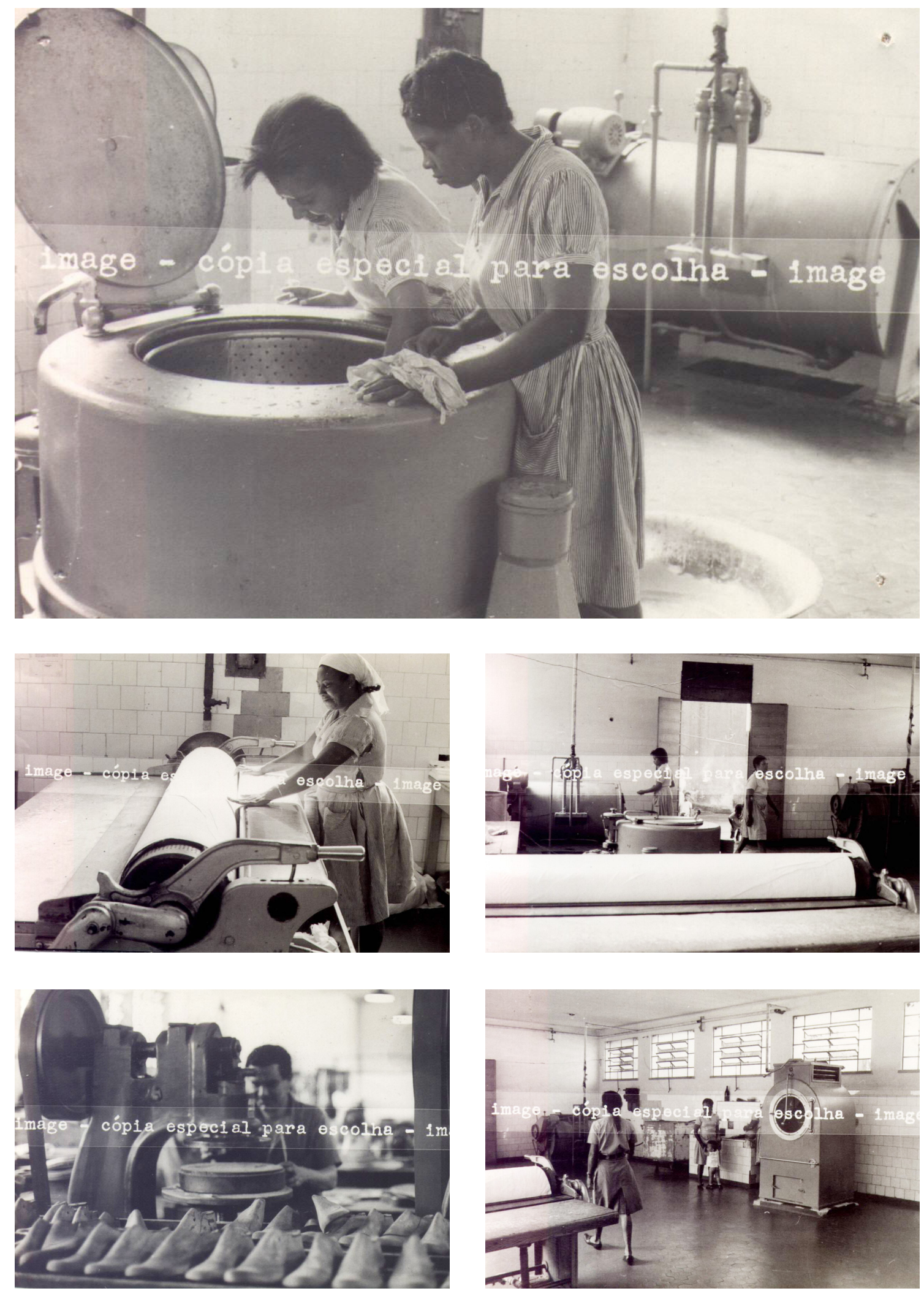

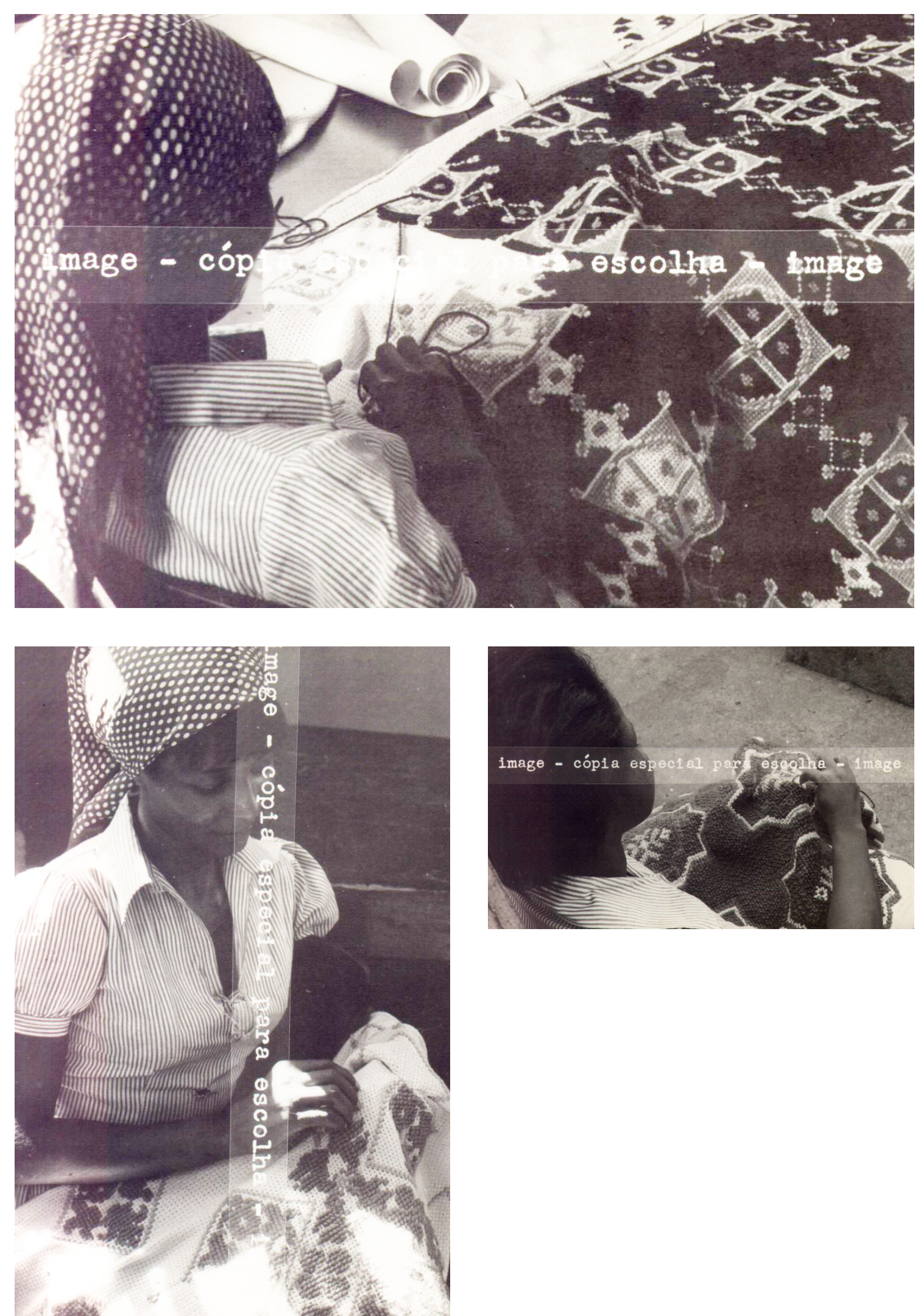
As fotografias do trabalho na penitenciária feminina, em um primeiro momento, aparentam ser atemporais: o cuidadoso bordado, as pinturas delicadas sobre o pano branco, a atenta paciência ao tecer e a expressão de tranquilidade daquelas que não parecem presidiárias. Mas não há como enganar o olhar. Sabe-se que as fotografias foram tiradas no ambiente prisional e que o trabalho que essas mulheres realizam é parte de uma ideologia carcerária mais ampla traçada pelos ideais de ressocialização por meio do trabalho e da ocupação do tempo prisional de maneira produtiva. Sabe-se também o que é esperado dessas mulheres e qual o papel social a elas traçado. O que mudou com a ausência das Irmãs? Pelas imagens pouco se pode dizer, mas há algumas permanências e rupturas às quais é possível atentar.

A privação da liberdade é a privação do tempo. Tempo em movimento, tempo extramuros, tempo social. A vida no cárcere é composta pela espera, pelo passar dos dias para que outros dias possam ser vividos. E esses momentos que se esvaem junto com a liberdade compoem a pena. O longo tapete que se tece ilustra a espera: o movimento do tempo se materializa no tecido. A linha tece o tempo. À margem do tempo social, dinâmico e em movimento, corre o tempo do confinamento. $\mathrm{O}$ silêncio parece imperar. $\mathrm{O}$ raio de luz que entra pela janela ilumina aquela que pacientemente tece seu tempo. A lente fotográfica capta um ambiente de serenidade, que compõe a imagem que se quer passar do cárcere: local de disciplina, trabalho e paciência.

O trabalho delicado nos tecidos contrasta com aquele junto às grandes máquinas de lavar e passar roupas. A lavanderia industrial transforma a técnica: do lavor caseiro passível de reprodução no ambiente doméstico, ao trabalho automatizado. A divisão sexual do trabalho persiste: enquanto as mulheres se dedicam aos afazeres manuais e aos cuidados com a rouparia, a alimentação e a limpeza, os homens se ocupam do trabalho fabril: por mais que haja mudanças na técnica, o modelo cárcere-lar dos presídios femininos segue contrastando com o da produtividade do cárcere-fábrica dos masculinos. 


\section{ENTRE BERÇOS E GRADES}
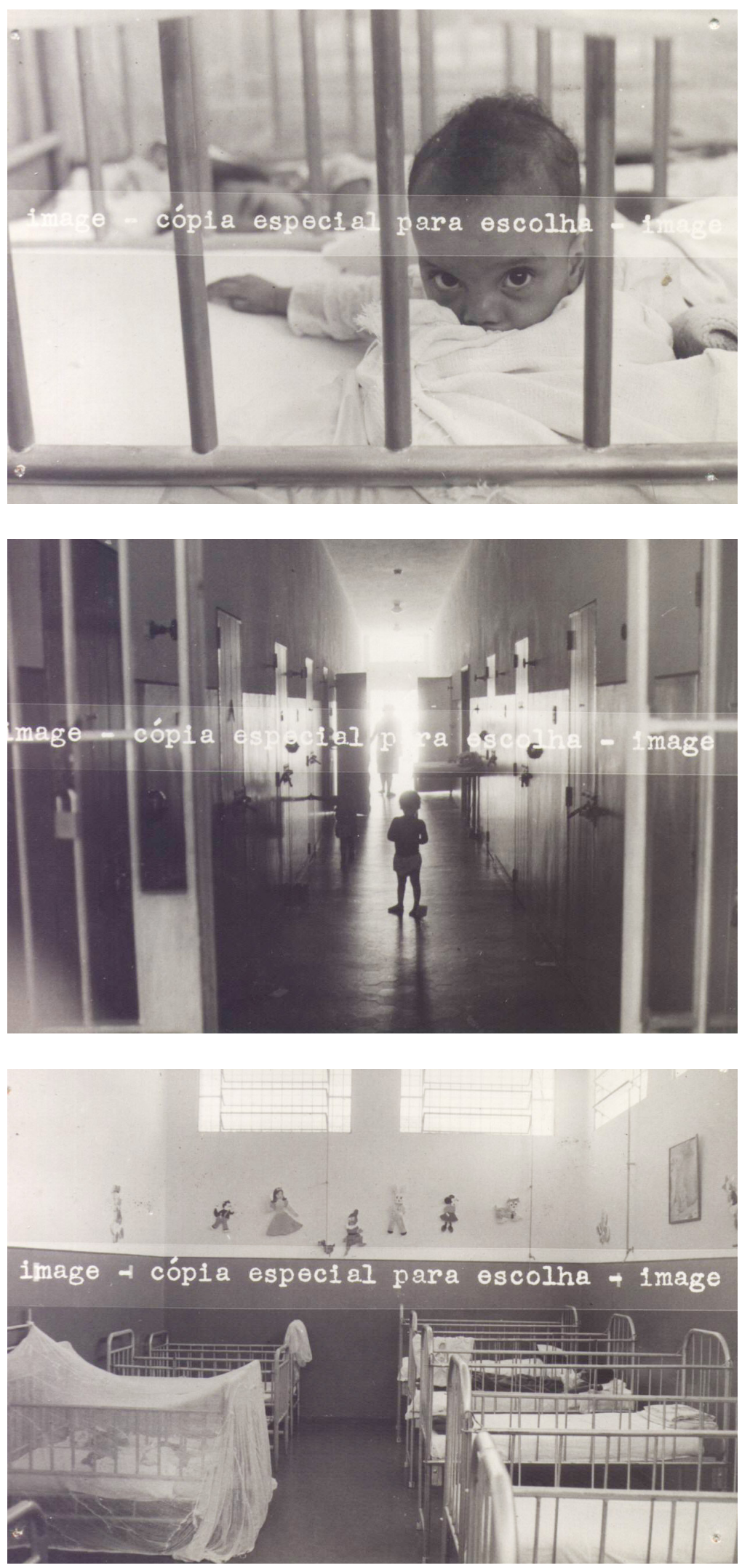
Imagens do berçario rompem com as sequências da prisão: o espaço fotografado poderia ser uma creche, um jardim de infância, um orfanato ou um hospital. Apesar do enquadramento da criança em clara analogia entre a grade do berço e as grades da prisão, é apenas no contexto que a proposta é entendida. Se, por um lado, o cuidado com os filhos é associado pelo Estado e pela sociedade às mães o que naturaliza, em certa medida, o berçário no cárcere - por outro, a imagem de crianças no ambiente prisional causa impacto. A própria instituição permite rupturas inusitadas com as representações que a rondam, gerando surpresa: as crianças em seus espaços é uma delas. 


\section{PERCURSO DO TEMPO}
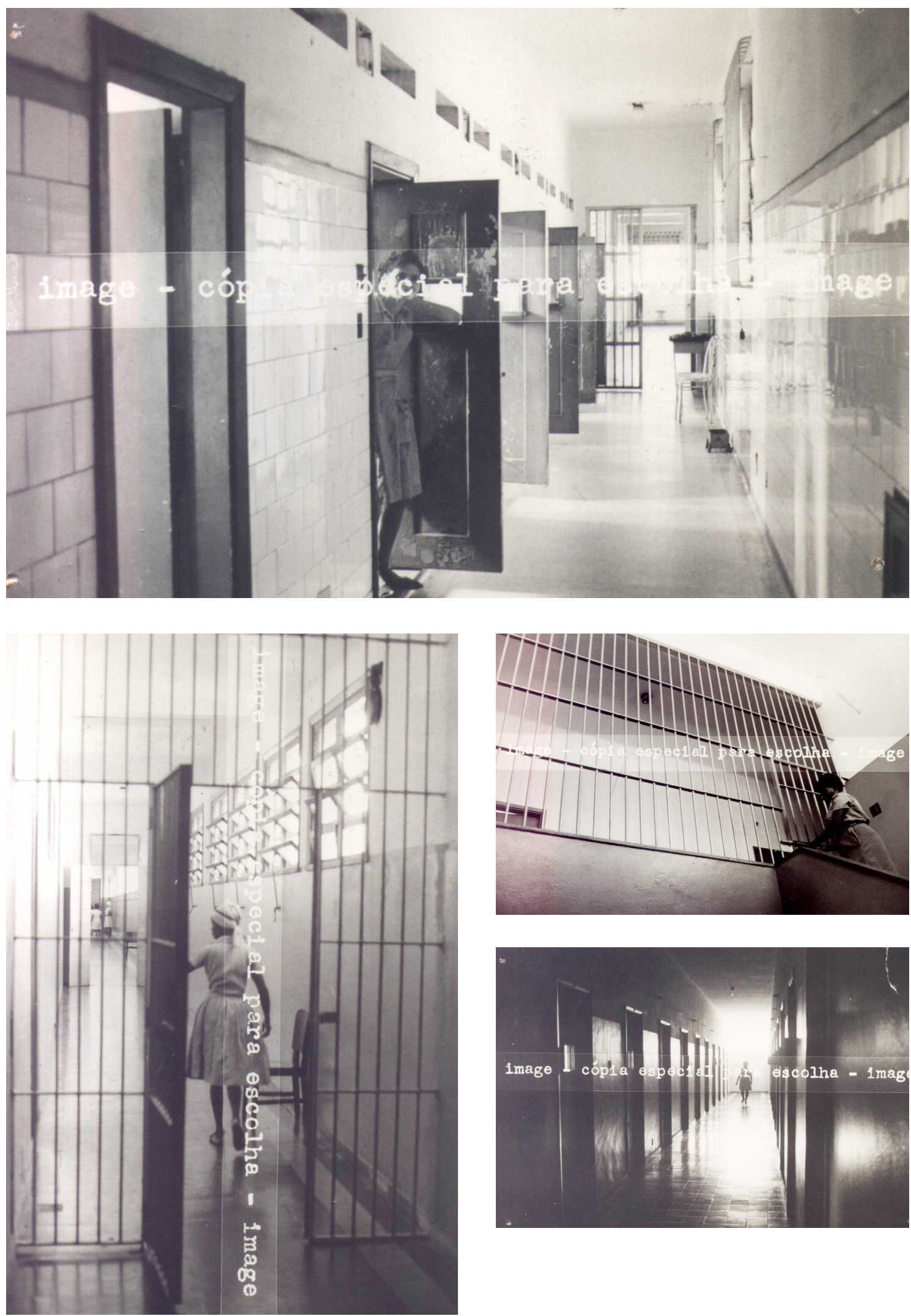

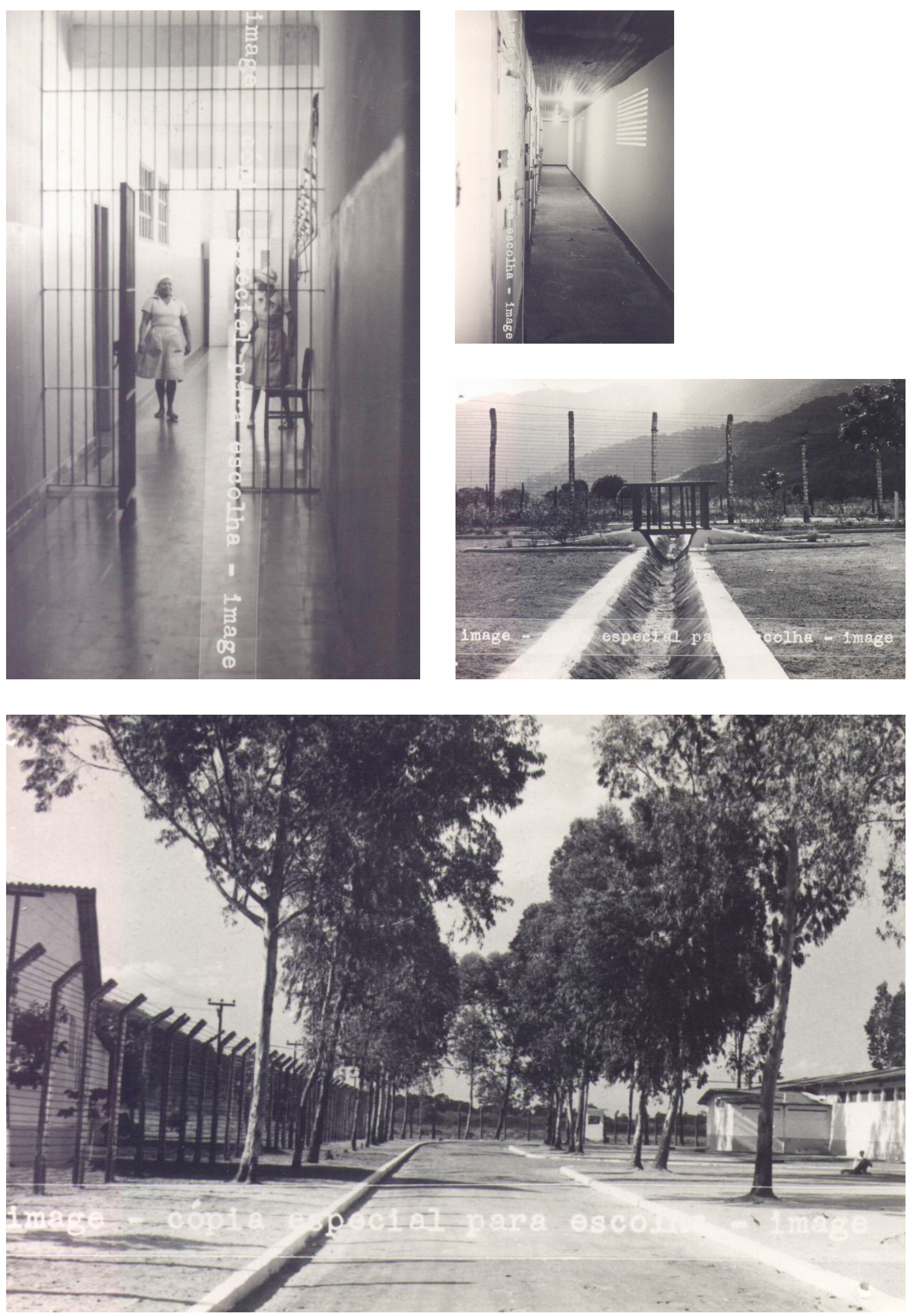
“...Conduziu-nos pelo corredor esmaltado de verde e de chão claro que refletia a figura dos que caminhavam mais à frente (...)", escreveu o repórter d'A Estre$l a$, que, se não fosse a justaposição das narrativas - a visual e a da matéria da revista poderia, em algumas passagens, estar se referindo às mesmas imagens que compóem esta série. No entanto, as grades e cadeados, ausentes nas narrativas dos primeiros tempos dos presídios femininos, fazem-se presentes nas fotografias ora analisadas. O discurso de humanização carcerária que, em meados do século XX, pretendia extirpar do ambiente prisional as semelhanças com as velhas masmorras se cumpriu, mas não a ponto de superar a imagem da prisão que está impressa em suas grades, nas janelas altas, no corredor isolado, formado por portas que se abrem e fecham no rigoroso controle do tempo. Transitar pelo espaço não é ter controle sobre ele. Stendhal, em $O$ Vermelho e o Negro, ao dizer que "quando se está preso o pior é não poder fechar-se a porta", ilustra a falta de autonomia dos reclusos, afinal, estar encarcerado é estar privado da liberdade de ser, transitar, de se expressar, de se ausentar. Estar preso é estar presente no cárcere, com suas regras, seus controles, suas medidas, seus horários.

Asséptica e impessoal, a representação da prisão é reforçada pela objetiva do fotógrafo que fixa as imagens das grades em diversos enquadramentos e o caminhar das mulheres entre luzes e sombras. Do lado de fora, depois do alambrado, a liberdade é expressa na perspectiva da alameda. Do isolamento celular ao mundo extragrades, as fotografias sugerem, mais uma vez, o percurso do tempo. 


\section{BIBLIOGRAFIA}

\section{BIBLIOGRAFIA CONSULTADA}

ALMEIDA, Cândido Mendes de. As mulheres criminosas no centro mais populoso do Brasil. Diário Official dos Estados Unidos do Brasil. Anno LXVII. N. 53. p. 6293 - 6298. Domingo, 4 de março de 1928

ALMEIDA, Rosemary de Oliveira. Mulheres que Matam - universo imaginário do crime no feminino. Rio de Janeiro: Relume Dumará, 2001.

ALVAREZ, Marcos César. Bacharéis, Criminologistas e Juristas - Saber Jurídico e Nova Escola Penal no Brasil. São Paulo: IBCCrim, 2003.

ANITUA, Gabriel Ignácio. Histórias dos pensamentos criminológicos. Rio de Janeiro: Revan, 2007.

BAHIA. Decreto No 11.214, 06 de Fevereiro de 1939.

BATISTA, Nilo; ZAFFARONI, Eugénio Raúl et al. Direito Penal Brasileiro I. Rio de Janeiro: Revan, 2003.

BESSE, Susan K. Modernizando a Desigualdade - reestruturação da ideologia de gênero no Brasil 1914-1940. São Paulo, Edusp, 1999. 
BEZERRA DE MENESES, Ulpiano T. Fontes visuais, cultura visual, História visual. Balanço provisório, propostas cautelares. Revista de História. Vol. 23, n. 45, p. $11-36,2003$.

BOHANNAN, Paul. A Antropologia e a Lei. In: VÁRIOS. Panorama da Antropologia. São Paulo: Editora Fundo de Cultura, 1966.

BRASIL. Constituição politica do Império do Brazil - 1824. Disponível em: www. planalto.gov.br/ccivil_03/constituicao/constituiçao24.htm. Acesso em: 11 de novembro de 2011.

BRASIL. Decreto-lei No 2.848, dezembro de 1940.

BRASIL. Decreto-lei No 3.688, outubro de 1941.

BRASIL. Ante-projecto do código penitenciário do Brasil. Diário Official. Ano LXXII. N. 203. 31 de agosto de 1933. p. 17175 - 17218.

BRASIL. Termos de Contrato - Ministério da Justiça e Negócios Interiores - Penitenciária Central do Distrito Federal. Diário Oficial. 12 de outubro de 1942. p. 15230.

BRASIL. Relatório do Patronato das Presas. Diário Official. 27 de julho de 1927. p. $16388-16390$.

CAIMARI, Lila M. Whose Criminals Are These? Church, State, and Patronatos and the Rehabilitation of Female Convicts (Buenos Aires, 1890-1940). The Americas, Vol. 54, N. 2, p. 185-208, Outubro de 1997.

CAMPOS, Margarida de Moraes. A Congregação do Bom Pastor na Província Sul do Brasil - pinceladas históricas. São Paulo: [s.n], 1981.

CARRARA, Sérgio; FRY, Peter. As vicissitudes do liberalismo no direito penal brasileiro. Revista Brasileira de Ciências Sociais, n. 2, p. 48-54, 1986.

CARRARA, Sérgio. Crime e Loucura - O aparecimento do manicômio judiciário na passagem do século. Rio de Janeiro: Eduerj/Edusp, 1998.

CHIES, Luiz Antônio Bogo (coord.). A prisão dentro da prisão - uma visão sobre o encarceramento feminino na 5. ${ }^{a}$ Região Penitenciária do Rio Grande do Sul. Pelotas: GITEP/UCPel, 2008. 
CORRÊA, Mariza. As Ilusões da Liberdade - a escola, Nina Rodrigues e a antropologia no Brasil. Bragança Paulista: Instituto Franciscano de Antropologia, 1998.

CÓSER, Silvana; MOTA, Joaquim; LOPES, Eliane. Julio Afrânio Peixoto (18761947) Ensaio Biográfico. In: HERSCHMANN, Micael M.; PEREIRA, Carlos Lemes (Org.). A Invenção do Brasil Moderno - Medicina, educação e engenharia nos anos 20-30. Rio de Janeiro: Rocco, 1994.

COSTA, Jurandir Freire. Ordem Médica e Norma Familiar. Rio de Janeiro: Graal, 1999.

CUNHA, Maria Clementina Pereira. O Espelho do Mundo - Juquery, a História de um Asilo. São Paulo: Paz e Terra, 1988.

CUNHA, Olívia Maria Gomes da. Intenção e Gesto: pessoa, cor e a produção cotidiana da (in) diferença no Rio de Janeiro, 1927-1942. Rio de Janeiro: Arquivo Nacional, 2002.

CUNHA, Olívia Maria Gomes da. Tempo Imperfeito: uma etnografia do arquivo. Revista Mana. Vol. 10, n 10/2, 2004.

. Criadas para servir: domesticidade, intimidade e retribuição. In: CUNHA, Olívia Maria Gomes da; GOMES, Flávio dos Santos (Org.). Quase-cidadão - Histórias e Antropologias da Pós-Emancipação no Brasil. Rio de Janeiro: FGV Editora, 2007.

DAERMON, Pierre. Médicos e Assassinos na Belle Époque. São Paulo: Paz e Terra, 1991.

DELLA CAVA, Ralph. Igreja e Estado no Brasil do Século XX. Estudos Cebrap. São Paulo, n.12, p. 7 - 52, abr. a jun. de 1975.

DOTTI, René Ariel. História da Legislação Penal Brasileira (Períodos Republicanos). Revista Brasileira de Ciências Criminais, São Paulo, n. 12, p. 222-233, out./dez. 1995.

DOTTI, René Ariel. A reforma penal e penitenciária 25 anos depois, disponível em: www.dotti.adv.br/artigosjp_319.html, acesso em 30/05/2011. 
DURKHEIM, Émile. Regras relativas à distinção entre o normal e o patológico (Capítulo III). In: As regras do Método Sociológico. $3^{\mathrm{a}}$ edição. São Paulo: Editora Nacional, 1963.

ENGEL, Magali. Psiquiatria e Feminilidade. In: PRIORE, Mary Del (Org). História das Mulheres no Brasil. São Paulo: Contexto, 1997.

EVANGELHO de Lucas. Bíblia de Jerusalém. São Paulo: Paulus, 2004.

FAUSTO, Boris. Crime e Cotidiano. São Paulo: Edusp, 2001. . História do Brasil. São Paulo: Edusp, 2000.

FERLA, Luis. Feios, Sujos e Malvados sob Medida - a utopia médica do biodeterminismo. São Paulo: Alameda, 2009.

FONSECA, Cláudia. Ser Mulher, Mãe e Pobre. In: PRIORE, Mary Del (Org). História das Mulheres no Brasil. São Paulo: Contexto, 1997. p. 510 - 553.

FOUCAULT, Michel. Vigiar e Punir. Petrópolis: Vozes, 2004. História da Sexualidade 1 - A Vontade de Saber. SP: Graal, 2006. . A Mulher/Os Rapazes - da História da Sexualidade. Rio de Janeiro: Paz e Terra, 1997.

FRY, Peter. Direito positivo versus direito clássico: a psicologização do crime no Brasil no pensamento de Heitor Carrilho. In: FIGUEIRA, Sérvulo (org.). Cultura da Pscicanálise. São Paulo: Brasiliense, 1985.

GÊNESIS. Bíblia de Jerusalém. São Paulo: Paulus, 2002.

GIBSON, Mary; RAFTER, Nicole Hahn. Editor's Introduction. In: LOMBROSO, Cesare; FERRERO, Guglielmo. Criminal Woman, the Prostitute, and the Normal Woman. Durham: Duke University Press, 2004. p. 3-33.

GIBSON, Mary; RAFTER, Nicole Hahn. Editor's Introduction. In: LOMBROSO, Cesare. Criminal Man. Durham: Duke University Press, 2006. p. 1 36.

GOFFMAN, Erving. Manicômios, Prisões e Conventos. São Paulo: Perspectiva, 2003. 
GIUMBELLI, Emerson. Para Além do 'Trabalho de Campo': reflexões supostamente malinowskianas. Revista Brasileira de Ciências Sociais, Vol 17, nº 48, p. 91-107, fev. de 2002.

GÓMEZ, Maria José Correa. Demandas Penitenciarias. Discusión y reforma de las cárceles de mujeres en chile (1930-1950). Historia. Pontificia Universidad Católica de Chile. Vol. I, n 38, p. 9-30, enero-junio 2005.

HOLANDA, Sérgio Buarque de. O Brasil Monárquico 1 - o processo de emancipação. São Paulo: Difel,1985.

ILGENFRITZ, Iara; SOARES, Bárbara Musumeci. Prisioneiras - vida e violência atrás das grades. Rio da Janeiro: Garamond, 2002.

KOERNER, Andrei. O Impossível "Panóptico Tropical Escravista”: práticas prisionais, política e sociedade brasielira do século XIX. Revista Brasileira de Ciências Criminais, São Paulo, Ano 9, p. 211-260, jul./set. 2001.

LEMOS BRITTO , José Gabriel de. Os Systemas Penitenciários do Brasil. Rio de Janeiro: Imprensa Oficial, 1924. VOLUME I e II.

, José Gabriel de. Psychologia do Adulterio. Rio de Janeiro: Livraria Jacintho, 1933.

, José Gabriel de. A Questão Sexual nas Prisões. Rio de Janeiro: Livraria Jacinto, 1934. , José Gabriel de. As Mulheres Criminosas e seu tratamento penitenciário. In Estudos Penitenciários. São Paulo: Imprensa Oficial, 1943.

LÉVI-STRAUSS, Claude. Tristes Trópicos. São Paulo: Companhia das Letras, 1996. LIMA, Elça Mendonça. Origens da Prisão Feminina no Rio de Janeiro. Rio de Janeiro: $\mathrm{OAB} / \mathrm{RJ}, 1983$.

LOMBROSO, Cesare; FERRERO, Guglielmo. Criminal Woman, the Prostitute, and the Normal Woman. Tradução de Gibson, Mary e Rafter, Nicole Hahn. Durham: Duke University Press, 2004.

LOMBROSO, Cesare. Criminal Man. Tradução de Gibson, Mary e Rafter, Nicole Hahn. Durham: Duke University Press, 2006. 
LOPES, José Reinaldo de Lima. O Direito na História - lições introdutórias. São Paulo: Max Limonad, 2002.

LOURO, Guacira Lopes. Mulheres na Sala de Aula. In: PRIORE, Mary Del (Org). História das Mulheres no Brasil. São Paulo: Contexto, 1997. p. 443 a 481.

LUGON, Olivier. La petite et la grande photographie. In : LUGON, Olivier. Le Style documentaire - D’Auguste Sander à Walker Evans. 1920-1945.Paris: Macula, 2001.

LUGON, Olivier. Séries, sequências e pranxas-contato. In : SALGUEIRO, Heliana Angotti (ed.). O olho fotográfico - Marcel Goutherot e seu tempo. São Paulo : FAAP, 2007.

LYRA, Roberto. Nôvo Direito Penal. Rio de Janeiro: Editor Borsoi, 1971.

MACEDO, Hilda. Criminalidade Feminina e sua Prevenção. In: Arquivos da Sociedade de Medicina Legal e Criminologia de São Paulo. Suplemento do Volume XXII de 1953 - Anais do $1^{\circ}$ Congresso Brasileiro de Medicina Legal e Criminologia, 1 Volume. São Paulo: [s.n.], 1953. p. 285 - 295.

MALINOWSKI, Bronislaw. Argonautas do Pacifico Ocidental. Coleção Os Pensadores. São Paulo: Abril, 1984.

MALUF, Marina; MOTT, Maria Lúcia. Recônditos do Mundo Feminino. In: SEVCENKO, Nicolau (Org.). História da Vida Privada no Brasil - República: da Belle Epoque à Era do Rádio. São Paulo: Companhia das Letras, 2008.

MAUSS, Marcel. As Técnicas do Corpo. In: Sociologia e Antropologia. São Paulo: Cosac Naify, 2003. p. 399 - 422.

MELOSSI, Dario; PAVARINI, Massimo. Cárcere e Fábrica - As origens do sistema penitenciário (séculos XVI - XIX). Rio de Janeiro: Revan, 2006.

MOTA, Cândido. E as Mulheres? In: Revista Penal e Penitenciária. Ano I, Vol. I, No 1, Fascículo 1º, p. 97 - 104, 1940.

OLMO, Rosa del. A América Latina e sua Criminologia. Rio de Janeiro: Revan, 2004. 
PADOVANI, Natália Corraza. "Perpétuas Espirais": Falas do poder e prazer sexual em trinta anos (1977-2009) na história da Penitenciária Feminina da Capital. 2010. Dissertação (Mestrado em Sociologia) - Departamento de Sociologia-IFCH. Unicamp, Campinas, 2010.

PEIXOTO, Afrânio. A Educação da Mulher. São Paulo: Companhia Editora Nacional, 1936.

PIERANGELLI, José Henrique. Códigos Penais do Brasil. Bauru: Jalovi, 1980.

POINSENET, Marie Dominique. Nada Impossivel ao amor. Tradução de Maria Margarida Campos. Salvador: Editora Mensageiro da Fé, 1968.

QUEIROZ, Rafael Mafei Rabelo. A Modernização do Direito Penal Brasileiro - Sursis, livramento condicional e outras reformas do sistema de penas clássico no Brasil, 1924-1940. São Paulo: Quartier Latin, 2007.

RAGO, Margareth. Do Cabaré ao Lar - a utopia da cidade disciplinar - Brasil 1890 a 1930. São Paulo: Paz e Terra, 1997a.

- Trabalho Feminino e Sexualidade. In: PRIORE, Mary Del

(Org). História das Mulheres no Brasil. São Paulo: Contexto, 1997b.

. Os Prazeres da Noite - prostituição e códigos da sexualidade feminina em São Paulo (1890-1930). São Paulo: Paz e Terra, 2008.

RIO DE JANEIRO. Decreto $N^{\circ} 3.971,24$ de dezembro de 1941.

RIO DE JANEIRO. Guia das internas da penitenciária central do Distrito Federal para mulheres. In: LIMA, Elça Mendonça. Origens da Prisão Feminina no Rio de Janeiro. Rio de Janeiro: OAB/RJ, 1983.

RIO GRANDE DO SUL. Decreto $N^{\circ} 7.601,5$ de dezembro de 1938.

SALLA, Fernando. As Prisóes em São Paulo: 1822-1940. São Paulo: Annablume, 1999. - Breves notas para a história do encarceramento em São Paulo a Penitenciária do Estado. In Revista Brasileira de Ciências Criminais. vol.5, fasc.20, out/dez, 1997, pp. 293-302.

. As pesquisas sobre as Prisões: um balanço preliminar. In KOERNER, Andrei. História da Justiça Penal no Brasil: pesquisas e análises. São Paulo: IBCCrim, 2006. 
SANT'ANNA, Marilene Antunes. Trabalho e Conflitos na Casa de Correção do Rio de Janeiro. In: Bretas, Marcos Luiz (org.). História das Prisóes no Brasil - Volume I. Rio de Janeiro: Rocco, 2009.

SÃO PAULO. Decreto No 12.116. 11 de agosto de 1941.

SÃO PAULO. Decreto -lei no 12.116 de 11 de agosto de 1941. Diário Oficial. Número 183. 12 de agosto de 1941.

SÃO PAULO. A estatística policial-criminal do estado - Ano de 1938. São Paulo: Tipografia do Gabinete de Investigações, 1939. Disponível em: http://www. seade.gov.br/produtos/bibliotecadigital/view/listarPublicacao.php. Acesso em 11 de novembro de 2011.

SÃO PAULO. A estatística policial-criminal do estado - Ano de 1941. São Paulo: Tipografia do Gabinete de Investigações, 1942. Disponível em: http://www. seade.gov.br/produtos/bibliotecadigital/view/listarPublicacao.php. Acesso em 11 de novembro de 2011.

SÃO PAULO. A estatística policial-criminal do estado - Ano de 1943. São Paulo: A Noite, 1944. Disponível em: http://www.seade.gov.br/produtos/bibliotecadigital/view/listarPublicacao.php. Acesso em 11 de novembro de 2011.

SÃO PAULO. Secretaria de Estado de Cultura, Processo 24601/1986.

SCHRITZMEYER, Ana Lúcia Pastore. Sortilégio de Saberes - curandeiros e juízes nos tribunais brasileiros (1900-1990). São Paulo: IBCCrim, 2004.

SCHWARCZ, Lilia Moritz. O Espetáculo das Raças - cientistas, instituições e questão racial no Brasil 1870 -1930. $8^{a}$ Reimpressão. São Paulo: Companhia das Letras, 2008.

. Questões de Fronteira - sobre uma antropologia da história. Novos Estudos Cebrap. no 72, p. 119 - 135, jul. 2005.

SERRA, Carlos Henrique Aguiar. O Pensamento Jurídico-Penal de Roberto Lyra e Nélson Hungria nos Anos 1937-1964: Estilos e Visões Teóricas Diferentes. In: KOERNER, Andrei. História da Justiça Penal no Brasil - pesquisas e análises. São Paulo: IBCCrim, 2006. 
SEVCENKO, Nicolau. Orfeu Extático na Metrópole - São Paulo, Sociedade e Cultura nos Frementes Anos 20. São Paulo: Companhia das Letras, 1992.

SMART, Carol. Woman, Crime and Criminology - A Feminist Critique. Londres: Routledge \& Kegan Paul, 1976.

SHECAIRA, Sérgio Salomão. Criminologia. São Paulo: Revista dos Tribunais, 2008. SHIRLEY, Robert Weaver. Antropologia Jurídica. São Paulo: Saraiva, 1987.

SOHN, Anne-Marie. O corpo sexuado. In: CORBAIN, A.; COURTINE, J.-J.; VIGARELLO, G. (org.). História do corpo 3 - As mutações do olhar. O século XX. Petrópolis: Vozes, 2008.

SOIHET, Rachel. Mulheres Pobres e Violência no Brasil Urbano. In: PRIORE, Mary Del (Org.). História das Mulheres no Brasil. São Paulo: Contexto, 1997. p. $362-400$.

SOUZA, Luís Antônio Francisco de. Lei, Cotidiano e Cidade - Polícia Civil e Práticas Policiais na São Paulo republicana (1889 - 1930). São Paulo: IBCCrim, 2009.

STEPAN, Nancy Leys. A Hora da Eugenia - raça, gênero e nação na América Latina. Rio de Janeiro: Editora Fiocruz, 2005.

ZEDNER, Lucia. Wayward Sisters - The prison for Woman. In: MORRIS, Norval; ROTHMAN, David. The Oxford History Of The Prison - The Practice of Punishment in Western Society. New York/Oxford: Oxford University Press, 1995. p. 329 - 361.

\section{PERIÓDICOS CONSULTADOS}

A Estrela: Órgão da Penitenciária Central do Distrito Federal. Rio de Janeiro.

Ano II, janeiro de 1945

Ano II, junho de 1945

Ano II, novembro de 1945

Ano II, dezembro de 1945

Ano I, abril de 1951 
Edição Especial sobre a Penitenciária Central, 1951

Ano I, junho de 1951, n³

Ano I, outubro de 1951

Ano I, novembro e dezembro de 1951, n 7 e 8

Ano II, janeiro de 1952, no 9

Ano II, fevereiro/março de 1952, no 9

Ano II, maio/junho de 1952, No 13 e 14

Ano II, julho /setembro de 1952, no 15 e 17

Ano II, outubro de 1952, n 18

Ano II, novembro/dezembro de 1952, no 19 e 20

Ano III, Janeiro/fevereiro de 1953, nº 21 e 22.

Ano III, março/abril de 1953, nº 23-24.

Ano III, maio/junho de 1953, nº 25 e 26

Ano III, julho/agosto/setembro de 1953, no 27,28 e 29.

Ano III, outubro/novembro/dezembro de 1953, nº 30,31 e 32 .

Ano IV, janeiro/fevereiro de 1954, no 33 e 34.

Ano IV, março/abril/maio de 1954, nº 35, 36 e 37

Ano IV, junho/julho de 1954, n 38 e 39

Ano V, agosto a fevereiro de 1954/1955, № 40/46

Arquivos Penitenciários do Brasil - Imprensa Nacional, Rio de Janeiro

Ano I, Volume I, n 1 e 2, $1^{\circ}$ e $2^{\circ}$ trimestre de 1940 - Rio de Janeiro, 1940.

Ano I, Volume I, n 4, 40 Semestre de 1940 - Rio de Janeiro, 1941 a.

Ano II, no $1,1^{\circ}$ Trimestre de 1941 - Rio de Janeiro, $1941 \mathrm{~b}$.

Ano II, no 2 e $3,2^{\circ}$ e $3^{\circ}$ trimestres de 1941 - Rio de Janeiro, 1942a.

Ano II, $n^{\circ}$ 4, $4^{\circ}$ Trimestre de 1941 - Rio de Janeiro, 1942b.

Ano III, $\mathrm{n}^{\circ} 1$ e $2,1^{\circ}$ e $2^{\circ}$ trimestre de 1942 - Rio de Janeiro, 1942c.

Ano III, $n^{\circ} 3$ e $4,3^{\circ}$ e $4^{\circ}$ trimestre de 1942 - Rio de Janeiro, 1942d.

Ano VI, no 1 a 4, 1945 - Rio de Janeiro, 1946.

Volume único, 1958 - Rio de Janeiro, 1958. 